Universidade de São Paulo

Instituto de Física

\title{
Desenvolvimento de ferramentas de análise da dinâmica de forças de tração durante o ciclo de contração de cardiomiócitos isolados in vitro
}

\section{Marcel Philippi Dorta}

Orientador: Prof. Dr. Adriano Mesquita Alencar

Tese de doutorado apresentada ao Instituto de Física da Universidade de São Paulo, como requisito parcial para a obtenção do título de Doutor em Ciências.

Banca Examinadora:

Prof. Dr. Adriano Mesquita Alencar - Orientador (IFUSP)

Prof. Dr. Antonio Carlos Bloise Júnior (IFUSP)

Prof. Dr. Fabio Gava Aoki (UNIFESP)

Prof. Dr. Danilo Roman Campos (UNIFESP)

Prof. Dr. Vinicius Bassaneze (HCFMUSP) 
FICHA CATALOGRÁFICA

Preparada pelo Serviço de Biblioteca e Informação do Instituto de Física da Universidade de São Paulo

Dorta, Marcel Philippi

Desenvolvimento de ferramentas de análise da dinâmica de forças de tração durante o ciclo de contração de cardiomiócitos in vitro. São Paulo, 2019.

Tese (Doutorado) - Universidade de São Paulo. Instituto de Física. Depto. de Física Geral

Orientador: Prof. Dr. Adriano Mesquita Alencar

Área de Concentração: Física

Unitermos: 1. Microscopia de força de tração; 2. Microscopia de fluorescência; 3 . Reologia; 4. Forças de tração.

USP/IF/SBI-087/2019 


\section{University of São Paulo}

Physics Institute

\section{Development of traction force dynamics analysis tools during the contraction cycle of isolated cardiomyocytes in vitro}

\section{Marcel Philippi Dorta}

Supervisor: Prof. Dr. Adriano Mesquita Alencar

Thesis submitted to the Physics Institute of the University of São Paulo in partial fulfillment of the requirements for the degree of Doctor of Science.

Examining Committee:

Prof. Dr. Adriano Mesquita Alencar - Supervisor (IFUSP)

Prof. Dr. Antonio Carlos Bloise Júnior (IFUSP)

Prof. Dr. Fabio Gava Aoki (UNIFESP)

Prof. Dr. Danilo Roman Campos (UNIFESP)

Prof. Dr. Vinicius Bassaneze (HCFMUSP) 

Dedico à minha família, especialmente a minha mãe e meus irmãos por todo apoio e incentivo. 



\section{Agradecimentos}

Gostaria de iniciar agradecendo do fundo do meu coração a Deus e a minha família. Meus irmãos, Renato e Renan, a minha mãe, Tânia e ao meu pai, Celso. Agradeço ao apoio de todos, especialmente a minha mãe que me deu toda a força e condição para que eu pudesse estar aqui hoje. Tudo isso é graças a você mãe, ao seu carinho, ao seu amor, a sua dedicação e por você ter acreditado em mim.

Agradeço aos meus amigos e parentes, que mesmo estando longe sempre me deram todo o apoio e carinho para que eu conseguisse superar todas as dificuldades do caminho. Vocês foram muito importantes pra mim. Eram vocês que sempre me faziam lembrar da minha terrinha querida, que me ligavam pra saber como eu estava, que me contavam coisas engraçadas, quando por aqui a situação não era das mais felizes. Muito obrigado por vocês existirem na minha vida.

Agradeço a todas as amizades feitas nestes últimos anos da minha vida. A amizade pra mim é algo muito importante e sempre me deu motivos pra sorrir e pra acreditar que a vida vale a pena ser vivida. No decorrer do Doutorado pude fazer grandes amigos que sempre me ajudaram quando foi preciso, agradeço ao Alexsandro, vulgo Gaúcho e ao meu grande amigo de sala de pesquisa, Fabris. Você me ajudou muito durante a minha pesquisa, sou eternamente grato pelos nossos bate papos e conselhos de caráter científico, que me ajudaram muito a dar andamento ao meu trabalho. Agradeço a todos os amigos de grupo de pesquisa, Alexandre, Jenifer, Isis e em especial o Antônio, a Mariana e o Edi, que foram fundamentais para que eu conseguisse terminar minha tese. Sou muito grato pela oportunidade de ter conhecido todos vocês e pelos bons e maus momentos que passamos juntos nestes últimos anos.

Agradeço ao meu orientador, Prof. Adriano, por ter aberto as portas do grupo 
para mim, por todo o apoio durante esse tempo de pesquisa. Sei que se hoje pude aumentar meu leque de conhecimento, me tornando mais capaz de encarar o mundo profissional e cientifico, graças as oportunidades geradas por você professor. Em nome do grupo, agradeço por sempre procurar deixar o ambiente de convivência do grupo o mais agradável possível, fazendo com que nos sentíssemos felizes trabalhando.

Sou muito grato ao querido Prof. Mikiya, por ter me dado a oportunidade de colaborar com seu grupo de Ensino de Física. O tempo que pude colaborar com o grupo foi muito enriquecedor e o aprendizado foi inestimável. Ter conhecido o e trabalhado com o Prof. Mikiya foi um dos grandes ganhos que eu tive na minha carreira. Por fim, agradeço ao Instituto de Física e ao órgãos de fomento, FAPESP, Capes e CNPq, por ter proporcionado todo o ambiente necessário para o andamento da pesquisa. 
"Sou eu próprio uma questão colocada ao mundo e devo fornecer minha resposta; caso contrário, estarei reduzido à resposta que o mundo me der. "

Carl Gustav Jung, Uma resposta ao nosso tempo 



\section{Resumo}

As propriedades mecânicas do coração têm sido estudadas extensivamente nos últimos anos, tanto em nível de órgão, tecido muscular, e recentemente em nível celular. As células cardíacas, ou cardiomiócitos, são células do músculo cardíaco, que é responsável pelo permanente fluxo sanguíneo no corpo, compondo os átrios e ventrículos, câmaras onde o sangue entra e é bombeado para o coração. A utilização de cardiomiócitos em experimentos científicos trouxe várias vantagens experimentais, assim como, a possibilidade de se estudar células isoladas de diversas áreas do coração. No presente trabalho foi desenvolvida uma metodologia de análise capaz de mensurar parâmetros relacionados a dinâmica de forças de tração de cardiomiócitos isolados durante os ciclos de contração, visando gerar um melhor entendimento na área de regeneração cardíaca. Para isso foram utilizadas duas linhagens de cardiomiócitos, WT, que são de cardiomiócitos saudáveis, e KO-CRP3, que são de cardiomiócitos que apresentam defeitos na arquitetura e funcionamento da musculatura cardíaca. A metodologia desenvolvida visa analisar parâmetros tais como, a frequência de pulsação dos cardiomiócitos, o alinhamento das forças de tração durante os ciclos de contração e a potência realizada pelo cardiomiócito durante a contração e o relaxamento. Esses parâmetros foram analisados em duas condições, com os cardiomiócitos em estados basais, e estimulados por um fármaco, o isoproterenol. Dessa forma foi possível analisar a resposta mecânica dos cardiomiócitos ao fármaco utilizado, e a diferença do comportamento dos parâmetros entre as linhagens de cardiomiócitos.

Palavras-chave: mecânica celular, microscopia de força de tração, microscopia de fluorescência, cardiomiócito, dinâmica de forças, reologia. 



\section{Abstract}

The mechanical properties of the heart have been studied studied extensively in recent years, both at organ level, muscle tissue, and recently at the cellular level. Heart cells, or cardiomyocytes, are cell of the heart muscle, which is responsible for the permanent blood flow in the body, making up the atria and ventricles, chambers where blood enters and is pumped into the heart. The use of cardiomyocytes in scientific experiments has brought several experimental advantages, as well as the possibility of studying isolated cells from different areas of the heart. In the present work an analysis methodology was developed capable of measuring parameters related to the dynamics of traction forces os isolated cardiomyocytes during the contraction cycles, aiming to generate a better understanding in the area of cardiac regeneration. For this we used two cardiomyocytes line, WT, which are from healthy cardiomyocytes, an KO-CRP3, which are from cardiomyocytes that have malfunction in cardiac muscle architecture. The developed methodology aims to analyze parameters such as the pulse rate of the cardiomyocytes, the alignment of the traction forces during the contraction cycles and the power performed by the cardiomyocytes during the contraction and relaxation. These parameters were analyzed under two conditions, with cardiomyocytes at basal state, and stimulated by a drug, isoproterenol. Thus it was possible to analyze the mechanical response of cardiomyocytes to the drug used, and the difference in the behavior of teh parameters between the cardiomyocytes line.

Keywords: cell mechanics, traction force microscopy, fluorescence microscopy, cardiomyocyte, force dynamics, rheology. 



\section{Lista de Figuras}

1.1 Esquema de formação de adesão focal. . . . . . . . . . . . . . . 25

1.2 Principais componentes do citoesqueleto. . . . . . . . . . . . . . . 29

1.3 Esquema da arquitetura da rede de actina. . . . . . . . . . . . . 31

1.4 Representação esquemática do perfil mecânico da actina. . . . . . . . . . 32

1.5 Módulo de Young de alguns materiais comuns. . . . . . . . . . . . . . . 34

1.6 Exemplos de algumas técnicas de microrreologia. . . . . . . . . . 36

2.1 Esquema da interação da célula com o substrato do TFM. . . . . . . . . . . 41

2.2 Esquema de um microscópio de fluorescência. . . . . . . . . . . . . . 45

2.3 Esquema do diagrama de Jablonski. . . . . . . . . . . . . . . . . 46

2.4 Microscópio de fluorescência utilizado e exemplo de algumas imagens

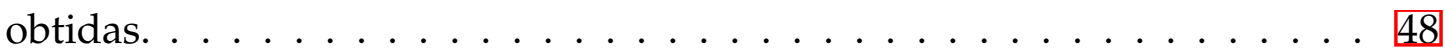

2.5 Sala de cultura celular. . . . . . . . . . . . . . . . . . . . 49

2.6 Esquema da representação das imagens obtidas pelo TFM na representação matricial. . . . . . . . . . . . . . . . . . . 51

2.7 Esquema da representação do mapa das forças de tração obtidas no experimento do TFM. . . . . . . . . . . . . . . . . . . . 52

2.8 Esquema da metodologia experimental. . . . . . . . . . . . 53

3.1 Fluxograma do processo experimental do TFM. . . . . . . . . . . . . 56

3.2 Comportamento do módulo da força de tração total. . . . . . . . . . . . . . 57

3.3 Comportamento da força resultante. . . . . . . . . . . . . . . 58

3.4 Histograma da distribuição dos ângulos do módulo da força de tração. . . 60

3.5 Curva do grau de alinhamento do módulo da força de tração resultante. . 61 
3.6 Curva do ângulo do deslocamento da força resultante. . . . . . . . . . 62

3.7 Histograma dos ângulos da força resultante. . . . . . . . . . . . . 62

3.8 Comparação entre os parâmetros de $F_{\mathrm{T}}, F_{\mathrm{R}}$, Curtose e $\theta_{F_{\mathrm{R}}} \ldots \ldots$. . . . . . 63

3.9 Comportamento do Momento contrátil resultante. . . . . . . . . . . . . 65

3.10 Curva de ajuste da potência. . . . . . . . . . . . . . . 65

3.11 Transformada de Fourier da força de tração. . . . . . . . . . . . . . 67

3.12 Exemplos de flutuação no comportamento da força total. . . . . . . . . . . 68

3.13 Descrição do gráfico de boxplot. . . . . . . . . . . . . . . . . 70

3.14 Flutuação da amplitude para os cardiomiócitos da linhagem WT. . . . . . 71

3.15 Anomalia de período de pulsação. . . . . . . . . . . . . . . 72

3.16 Flutuação do período de pulsação. . . . . . . . . . . . . . . . 72

4.1 Histograma da Curtose. . . . . . . . . . . . . . 76

4.2 Histograma do valor de Curtose da moda por linhagem de cardiomiócito. 77

4.3 Diferença da Curtose da moda entre o estado basal e com isoproterenol para as linhagem WT e KO-CRP3 de cardiomiócitos. . . . . . . . . . 78

4.4 Esquema para o cálculo da Curtose dos pontos de máximo e mínimo da $F_{\mathrm{T}}$. 79

4.5 Histograma do valor de Curtose máxima por linhagem de cardiomiócito. 80

4.6 Diferença da Curtose dos pontos de máximo entre o estado basal e com isoproterenol para as linhagem WT e KO-CRP3 de cardiomiócitos. . . . . 81

4.7 Histograma do valor de Curtose mínima por linhagem de cardiomiócito. . 82

4.8 Diferença da Curtose dos pontos de mínimo entre o estado basal e com isoproterenol para as linhagem WT e KO-CRP3 de cardiomiócitos. . . . . 83

4.9 Histograma dos ângulos entre as linhagens. . . . . . . . . . . . . . . 84

4.10 Mapa do vetor de forças de tração média e orientação de uma amostra de cardiomiócito da linhagem WT. . . . . . . . . . . . . . . 85

4.11 Mapa do vetor de forças de tração média e orientação de uma amostra de cardiomiócito da linhagem KO-CRP3. . . . . . . . . . . . . . . . 86

4.12 Histograma da potência de contração e relaxamento para cardiomiócitos da linhagem WT.

4.13 boxplot da potência de contração e relaxamento para cardiomiócitos da linhagem WT. 
4.14 Histograma da potência de contração e relaxamento para cardiomiócitos da linhagem KO-CRP3. . . . . . . . . . . . . . . . . . . 89

4.15 boxplot da potência de contração e relaxamento para cardiomiócitos da linhagem KO-CRP3. . . . . . . . . . . . . . . . . . . 90

4.16 Histograma da frequência máxima da $F_{\mathrm{T}}$ entre as linhagens WT e KO-CRP3. 91

4.17 Frequência média da $F_{\mathrm{T}}$ entre as linhagens de cardiomiócitos. . . . . . . 92

4.18 Flutuação da amplitude da $F_{\mathrm{T}}$ para a linhagem WT. . . . . . . . . . . . 93

4.19 Flutuação da amplitude da $F_{\mathrm{T}}$ para a linhagem KO-CRP3. . . . . . . . . . . 94

4.20 Flutuação do período da $F_{\mathrm{T}}$ para a linhagem WT. . . . . . . . . . . . 95

4.21 Flutuação do período da $F_{\mathrm{T}}$ para a linhagem KO-CRP3. . . . . . . . . . . 96

4.22 Comparação entre os parâmetros de $F_{\mathrm{T}}$ e da Curtose para um cardiomiócito da linhagem KO-CRP3. . . . . . . . . . . . . . . . . . . 99

4.23 Mapa do vetor de forças de tração para pontos de curtose máxima e mínima de um cardiomiócito linhagem WT no estado basal. . . . . . . . . 100

4.24 Mapa do vetor de forças de tração para pontos de curtose máxima e mínima de um cardiomiócito linhagem WT estimulado com isoproterenol.101

4.25 Mapa do vetor de forças de tração para pontos de curtose máxima e mínima de um cardiomiócito linhagem KO-CRP3 no estado basal. . . . . . 102

4.26 Mapa do vetor de forças de tração para pontos de curtose máxima e mínima de um cardiomiócito linhagem KO-CRP3 estimulado com isoproterenol. . . . . . . . . . . . . . . . . . 103

4.27 Comparação entre a frequência média da $F_{\mathrm{T}}$ e a flutuação do período e da amplitude na linhagem WT. . . . . . . . . . . . . . . . . . . 105

4.28 Comparação entre a frequência média da $F_{\mathrm{T}}$ e a flutuação do período e da amplitude na linhagem KO-CRP3. . . . . . . . . . . . . . . . . . . 106

4.29 Exemplo da flutuação da amplitude da $F_{\mathrm{T}}$ para um cardiomiócito da linhagem WT. . . . . . . . . . . . . . . . . . . 107

4.30 Exemplo da flutuação do período da $F_{\mathrm{T}}$ para um cardiomiócito da linhagem KO-CRP3. . . . . . . . . . . . . . . . . . . . . . 108 



\section{Lista de Tabelas}

4.1 Cardiomiócitos com alto grau de alinhamento, referente à moda da distribuição. . . . . . . . . . . . . . . . . 79

4.2 Cardiomiócitos com alto grau de alinhamento, referente aos pontos de máximo da $F_{\mathrm{T}} \ldots \ldots \ldots \ldots \ldots \ldots \ldots$

4.3 Cardiomiócitos com alto grau de alinhamento, referente aos pontos de mínimo da $F_{\mathrm{T}} \ldots \ldots \ldots \ldots \ldots \ldots \ldots$

4.4 Mediana e intervalo interquartil da Potência de contração e relaxamento. . 91

4.5 Mediana da distribuição da frequência máxima. . . . . . . . . . . . 92

4.6 Comparação entre os dados de alinhamento e potência. . . . . . . . . . . . 97 



\section{Sumário}

1. Introdução . . . . . . . . . . . . . . . . . . . 21

1.1 Contextualização e Justificativa . . . . . . . . . . . . . . . . . . 21

1.2 Estrutura intracelular . . . . . . . . . . . . . . . . . 28

1.3 Microrreologia celular . . . . . . . . . . . . . . . B2

2. Técnicas experimentais . . . . . . . . . . . . . . . 39

2.1 Microscopia de força de tração $\ldots \ldots \ldots \ldots$

2.2 Microscopia de fluorescência $\ldots \ldots \ldots \ldots \ldots$

2.3 Metodologia experimental . . . . . . . . . . . . . . . . 4 48

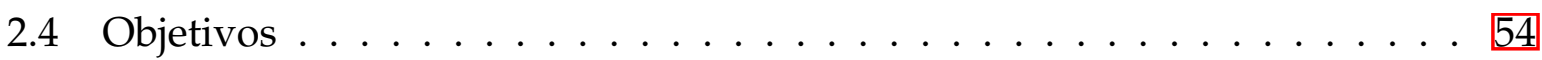

3. Desenvolvimento das ferramentas de análise . . . . . . . . . . 55

3.1 Forças de tração . . . . . . . . . . . . . . . . . . . . Б6

3.2 Quantificação de parâmetros estruturais de alinhamento das forças de

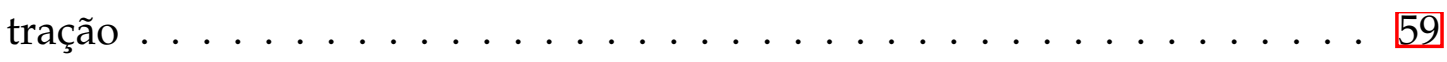

3.3 Potência de contração . . . . . . . . . . . . . . . . . . . 64

3.4 Análise de Fourier . . . . . . . . . . . . . . . . . 66

3.5 Análise das flutuações $\ldots \ldots \ldots$. . . . . . . . . . . . . 67

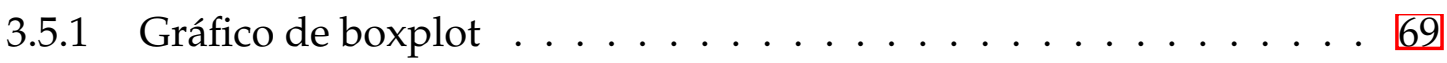

3.5 .2 Flutuação na amplitude $\ldots \ldots \ldots \ldots \ldots \ldots$

3.5.3 Flutuação do Período . . . . . . . . . . . . . . . . . . . 71

4. Resultados e discussão das ferramentas de análise desenvolvidas . . . . . . 75

4.1 Resultados ....................... 75 
4.1 .1 Curtose . . . . . . . . . . . . . . . . 75

4.1.2 Orientação das forças de tração . . . . . . . . . . . . . . . . 84

4.1.3 Potência de contração e relaxamento . . . . . . . . . . . . . 866

4.1.4 Transformada de Fourier das forças de tração . . . . . . . . . . . 91

4.1.5 Flutuações da amplitude e do período . . . . . . . . . . . . . . 93

4.2 Discussão . . . . . . . . . . . . . . . . . . . . . . . 97

4.3 Conclusões . . . . . . . . . . . . . . . . . . . . . . . . 109

Referências . . . . . . . . . . . . . . . . . . . . . . 1111

Apêndice

123

A. Protocolo da preparação do substrato de gel do TFM . . . . . . . . . . . . . . 1125

A.1 Primeira etapa: Preparação da primeira camada do gel . . . . . . . . . 1125

A.2 Segunda etapa: Preparação da segunda camada do gel . . . . . . . . . 126

A.3 Terceira etapa: Ativação do gel para depósito dos cardiomiócitos . . . . 1127

B. Trabalho publicado sobre a metodologia de alinhamento . . . . . . . . . . 129 


\section{Capítulo 1}

\section{Introdução}

Nesse capítulo, será apresentado o contexto científico atual em que os estudos em células cardíacas estão inseridos. Essa contextualização será feita dentro de uma perspectiva multidisciplinar entre as áreas de Física e Biologia Celular, na qual se inclui o presente trabalho. Discutir-se-á as bases conceituais dos objetos de estudos referentes à pesquisa aqui realizada, desde os tipos de células que utilizaremos, suas principais características, as técnicas experimentais e teóricas desse campo de pesquisa e as questões que ainda estão em aberto e que motivaram a pesquisa aqui desenvolvida. Por fim, serão apresentados os objetivos do presente trabalho.

\subsection{Contextualização e Justificativa}

Doenças cardiovasculares, como o infarto do miocárdio, representam a maior causa de morte no mundo, matando mais de 7 milhões de pessoas por ano, segundo dados da Organização Mundial da Saúde (OMS) no ano de 2012 (Takahashi et al., 2013; Gaui et al. 2014). Segundo dados do Ministério da Saúde, no Brasil, as doenças cardiovasculares constituem a maior causa de óbito em todas as regiões do país, atingindo a parcela de $29 \%$ do número total de mortes (Gaui et al., 2014).

O coração é um órgão composto por células eletricamente excitáveis que, durante o tempo de vida do corpo humano, trabalha como uma bomba mecânica de sangue (Zhang et al., 2008). A principal função do coração é bombear o sangue pelo corpo de acordo com as necessidades fisiológicas de cada órgão (Madonna et al. 2014: Vikhorev e Vikhoreva, 2018). Cardiomiopatias são doenças no músculo do coração que podem levar à disfunções cardíacas. Existem diversos tipos de cardiomiopatias, como: cardiomiopatia 
hipertrófica, miocardiopatia congestiva ou restritiva e arritmia cardíaca (Vikhorev e Vikhoreva, 2018). Em um trabalho recente, os pesquisadores Vikhorev e Vikhoreva publicaram um artigo de revisão, onde resumiram os principais dados sobre alterações nas propriedades contráteis do músculo cardíaco humano com a cardiomiopatia hipertrófica e a miocardiopatia congestiva (Vikhorev e Vikhoreva, 2018).

A contração do coração depende da despolarização elétrica da membrana do citoplasma, no entanto, alguns estudos têm mostrado que perturbações mecânicas afetam a eletrofisiologia cardíaca (Pfeiffer et al., 2014; Vikhorev e Vikhoreva, 2018; Prinzen e Peschar, 2002: Quinn et al., 2011). O processo que faz com que a ativação elétrica nas fibras musculares desencadeie contrações mecânicas é chamado de acoplamento excitação-contração (AEC) (Pfeiffer et al., 2014). Enquanto que, o processo no qual alterações mecânicas influenciam a atividade elétrica cardíaca é conhecido como resposta mecanoelétrica (RME) (Pfeiffer et al., 2014). Esses fenômenos podem ocorrer tanto no coração como um todo, quanto em nível celular.

As células cardíacas, ou cardiomiócitos, são responsáveis pelo permanente fluxo sanguíneo no corpo, compondo os átrios e ventrículos. Essas células estão interconectadas no músculo cardíaco, de forma que, quando uma delas é excitada, o potencial de ação se propaga para todas as demais, passando de célula para célula, inclusive por suas interconexões. Esse processo, conhecido como despolarização elétrica, leva à contrações mecânicas das células, que podem afetar o comportamento eletrofisiológico celular (Pfeiffer et al., 2014).

Os cardiomiócitos também possuem a capacidade de encurtarem ou alongarem suas fibras, sendo bastante flexíveis e fundamentais para o batimento cardíaco, que ocorre mesmo em meio de cultura. Os cardiomiócitos são estimulados eletricamente de forma indireta pelas células de marcapasso. Esse estímulo é transmitido célula a célula permitindo ao músculo cardíaco se comportar como uma única unidade coordenada (Severs, 2000). Nesse caso, a comunicação entre os cardiomiócitos é complexa e estabelecida de maneira mecânica, elétrica e química (Tirziu et al., 2010).

As propriedades mecânicas do coração têm sido estudadas extensivamente nos últimos anos, tanto em nível de órgão, tecido muscular, e recentemente em nível celular (Parikh et al., 1993). Inicialmente, os estudos voltados para o coração como um todo tinham como área de interesse a intervenção farmacológica e cirúrgica. Com o conhe- 
cimento acumulado, foi possível desenvolver técnicas para a preparação de músculos cardíacos, o que levou a manipulações experimentais mais diretas desse músculo (Louch et al. 2011). No entanto, em análises eletrofisiológicas do músculo cardíaco, verificou-se que não se tinha um controle adequado do potencial de membrana em determinados experimentos. Essa limitação possibilitou o desenvolvimento de técnicas para se isolar cardiomiócitos individuais (Louch et al., 2011).

A utilização de cardiomiócitos em experimentos científicos trouxe várias vantagens, como a possibilidade de se estudar células de diversas áreas do coração, tais como, átrio, ventrículo esquerdo ou direito, até mesmo regiões do coração que sofreram infarto (Louch et al., 2011). Outras vantagens estão relacionadas às técnicas experimentais de imagens, pois, para várias dessas técnicas, as amostras, em geral, têm um limite de espessura (Louch et al., 2011). É comum o uso de cardiomiócitos em estudos que visam analisar propriedades dos canais de cálcio, mecânica celular, transfecção gênica, entre outras (Louch et al., 2011). Dessa forma, vê-se que cardiomiócitos isolados podem ser utilizados em uma gama de experimentos que possibilitam a visualização de estruturas intra celulares que são importantes para o entendimento de propriedades mecânicas, estruturais e fisiológicas dos cardiomiócitos (Louch et al. 2011).

Diversos estudos em nível celular têm sido desenvolvidos nos últimos anos, a fim de entender melhor os mecanismos físicos e biológicos que regem o comportamento dos cardiomiócitos. Um desses estudos, se propôs a investigar a diferença no potencial de ação e na contração de cardiomiócitos com diferentes heterogeneidades (Khokhlova et al., 2018). Basicamente, os pesquisadores investigaram a heterogeneidade eletromecânica de cardiomiócitos de diferentes regiões da parede ventricular, sendo os modelos utilizados: os cardiomiócitos das regiões ventriculares do subendocárdio (ENDO) e do subepicárdio (EPI) (Khokhlova et al. 2018). Com essa pesquisa, Khokhlova et al., mostraram que a heterogeneidade mecânica se relaciona diretamente com dinâmica do tempo de ativação de cálcio e no perfil da contração dos cardiomiócitos, via um mecanismo de cooperação chamado de resposta eletro-cálcio-mecânica (Khokhlova et al., 2018).

Células, no geral, estão constantemente submetidas à ação de forças, que podem ser na forma de tensão de cisalhamento durante o fluxo sanguíneo ou a respiração, assim como, forças de tensão e compressão durante a contração muscular (Jansen et al., 2015). Procurar entender como as células reagem a essas forças, ou a rigidez do meio no qual 
elas estão aderidas, pode contribuir para o avanço na área de engenharia de tecido, onde se procura projetar biomateriais à base de células tronco, que podem ser utilizados para substituir tecidos ou órgãos do corpo (Jansen et al., 2015).

Nessa linha, um grupo de pesquisadores, Boothe et al., investigaram o efeito que a rigidez do substrato pode ter sobre as propriedades eletrofisiológicas de cardiomiócitos (Boothe et al. 2016). Para isso, cardiomiócitos ventriculares de ratos neonatos foram cultivados sobre a superfície de géis de poliacrilamida, onde se variou o módulo elástico do gel de 1 a $25 \mathrm{kPa}$ e foi monitorado o potencial de ação e a corrente de cálcio nos cardiomiócitos, pela técnica de patch clamping (Boothe et al. 2016). Uma das conclusões que os pesquisadores chegaram foi de que a rigidez do substrato afeta significativamente as correntes de cálcio, o que pode levar a alterações no potencial de ação dos cardiomiócitos (Boothe et al., 2016).

Trabalhos como esse, mostram a importância de se realizar estudos mecânicos a nível celular. Uma das características essenciais desses estudos em células está relacionado a mecanosensitividade e mecanotransdução celular. A mecanosensitividade é o processo pelo qual a célula sente os sinais mecânicos provenientes do meio no qual ela está inserida, enquanto que, a mecanotransdução é o processo de resposta celular aos sinais mecânicos recebidos (Jansen et al., 2015; Trepat et al., 2008; Moeendarbary e Harris, 2014; Zhu et al. 2000). Uma das formas das células interagirem com o meio extracelular é por forças de tração realizadas através de adesões focais, conforme exemplificado na Fig. 1.1. 


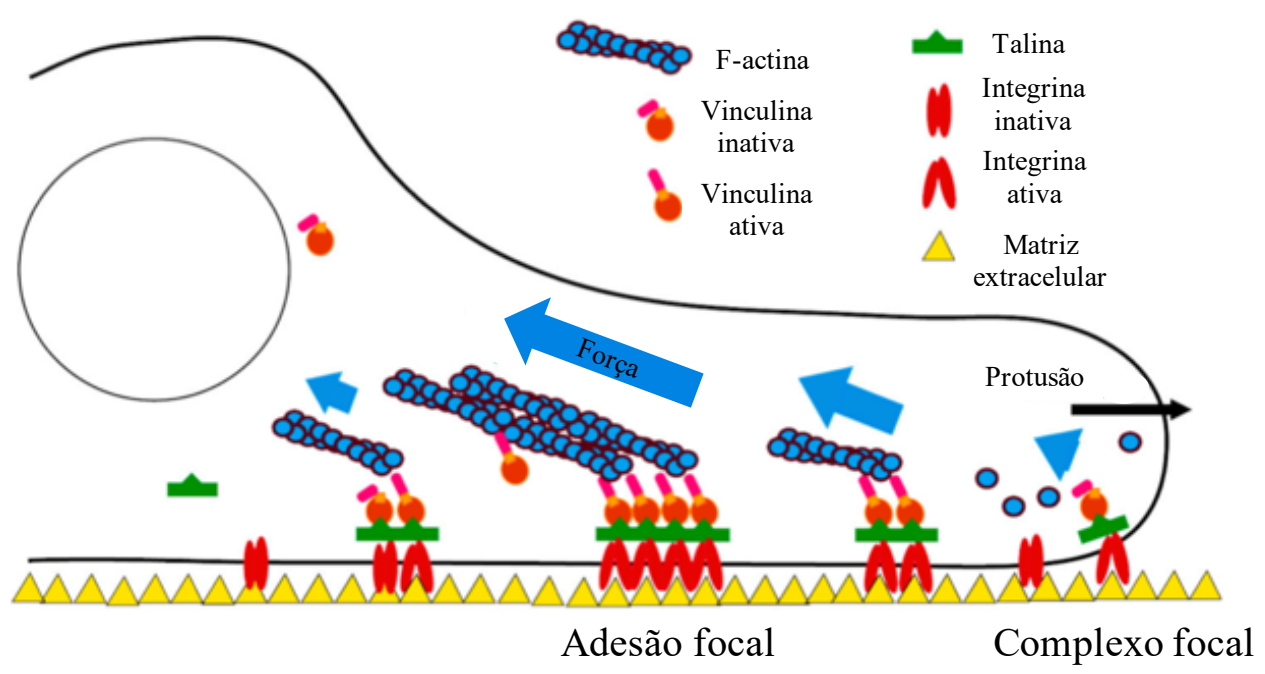

Figura 1.1: Esquema sobre o processo de formação de adesões focais. As interações de baixa afinidade entre a vinculina e a talina é o que inicia as adesões complexas. Quando a vinculina fica ativada, a conformação das adesões muda e passa de uma baixa para uma alta afinidade entre a vinculina e a talina, o que estabiliza uma conformação ativa com as integrinas gerando as adesões focais (figura adaptada de (Humphries et al., 2007)).

O esquema mostra a interação entre as proteínas e os tipos de sinalização que formam a base para que a adesão focal ocorra. As protusões se conectam com os elementos da matriz extracelular, via moléculas de adesão, ativando os receptores da família das integrinas que, por sua vez, ativam as quinases de adesão focal (Humphries et al. 2007). As integrinas se acoplam às fibras de actina (F-actina) do esqueleto celular (citoesqueleto) por proteínas adaptadoras que, em seguida, se agrupam para formar pequenos complexos focais que se estabilizam e formam as adesões. São esses processos que modulam diversas atividades celulares, como a migração celular e os processos de remodelamento (Humphries et al., 2007).

A fim de se obter uma melhor compreensão das propriedades mecânicas e elétricas dos cardiomiócitos Tian et al., acoplaram em um só equipamento um arranjo de microeletrodos com um microscópio de força atômica (AFM do inglês Atomic force microscopy) (Tian et al., 2017). Com o AFM foi possível mensurar a força dos cardiomiócitos através do ajuste da ponta do microscópio com o ciclo de contração-relaxamento das células (Tian et al. 2017) (maiores detalhes sobre o AFM, ver seção 1.3). Dessa forma, os pesquisadores conseguiram criar uma ferramenta capaz de prover dados experimentais que podem ajudar no melhor entendimento dos mecanismos eletromecânicos que regulam o 
funcionamento de cardiomiócitos (Tian et al., 2017).

Poder realizar medidas sobre o ciclo de contração e relaxamento dos cardiomiócitos é fundamental para a análise de fenótipos de doenças, farmacologia de segurança cardíaca e medidas do funcionamento cardíaco ao longo do tempo, com medidas tanto in-vitro como in-vivo (Sala et al., 2018). Seria de fundamental importância que esse tipo de medida pudesse ser realizada em condições clínicas e laboratórios de pesquisa, entretanto, segundo Sala et al., a maioria desses estudos são realizados em laboratórios que não são especialistas na área (Sala et al., 2018). Dessa forma, os autores propõem uma metodologia versátil que pode ser aplicada à maioria das imagens de contração cardíaca, encontrada em laboratórios ou clínicas especializadas, chamado MUSCLEMOTION (Sala et al., 2018).

O MUSCLEMOTION pode ser utilizado em sequência de imagens que podem ser carregadas no programa de processamento de imagens, ImageJ (Sala et al., 2018). Essa metodologia determina mudanças dinâmicas na intensidade dos pixels entre uma imagem e outra de uma sequência. Com isso, é possível obter medidas do movimento relativo durante a contração e relaxamento do cardiomiócito (Sala et al., 2018). Dessa forma, uma das conclusões dos autores foi a de que o MUSCLEMOTION pode ser utilizado como um método de análise da contração cardíaca em diversas modalidades, para uma rápida e confiável identificação de fenótipos de doenças, efeitos cardiotóxicos, entre outros (maiores detalhes da metodologia desenvolvida pode ser visto aqui (Sala et al. 2018)).

Atualmente, existem diversas técnicas experimentais capazes de extrair informações referentes ao comportamento mecânico de células vivas, como a microscopia de força de tração (TFM, do inglês Traction Force Microscopic) e a citometria óptica magnética de rotação (OMTC, do inglês Optical Magnetic Twisting Cytometry), por exemplo. Ambas as técnicas são relativamente novas, e a maioria das pesquisas científicas estão em um nível muito básico no que se refere a sua aplicação em cardiomiócitos (Style et al., 2014: Tang et al. 2014; Mertz et al., 2012; Butler et al., 2002; Deng et al., 2004; Kollmannsberger e Fabry, 2011).

Em um trabalho recente, Kijlstra et al., utilizaram a técnica de TFM para analisar a cinética de contração e a geração de força de células tronco derivadas de cardiomiócitos (Kijlstra et al., 2015). A capacidade de se realizar a diferenciação cardíaca de células 
tronco pluripotentes veio com o avanço recente na área de Biologia Celular e, com isso, possibilitou uma gama de estudos in-vitro de cardiomiócitos, gerando uma fonte de células para o estudo da medicina cardiovascular regenerativa (Chong et al., 2014; Zimmermann et al., 2006; Kijlstra et al., 2015). A análise da cinética de contração foi baseada na quantificação de alterações morfológicas ao longo do tempo, na célula como um todo. Já a geração de força dos cardiomiócitos foi quantificada pela deformação de um substrato flexível, onde as células ficavam aderidas pela técnica de TFM (maiores detalhes sobre o TFM, ver a seção 2.1) (Kijlstra et al., 2015).

No presente trabalho desenvolveu-se uma metodologia de análise capaz de mensurar novos parâmetros, a fim de agregar um melhor entendimento da dinâmica de forças de células vivas. Para isso, utilizou-se dois tipos de cardiomiócitos, fornecidos pelo grupo HC/FMUSP/InCor (Laboratório de Genética e Cardiologia Molecular). Esses mesmos tipos de células são utilizadas pelo grupo do InCor como modelo animal, visando aplicações para regeneração do coração, são eles: cardiomiócitos de rato neonato do tipo selvagem (WT, do inglês Wild Type) e cardiomiócitos de rato neonato geneticamente modificados pelo grupo de Genética do InCor (KO-CRP3).

A proteína muscular rica em cisteína, CRP3, é constituída de 194 aminoácidos e tem se tornado um importante modelo experimental em cardiologia desde que demonstrouse que uma deficiência no CRP3 pode levar à hipertrofia do miocárdio, seguida de uma cardiomiopatia dilatada (Buyandelger et al., 2011; Arber et al., 1994). A proteína CRP pode ser encontrada em três tipo: CRP1, CRP2 e CRP3. Existem evidências que sugerem que a proteína CRP3 regula a proliferação e diferenciação celular pelo controle do processo de transcrição gênica (Campos et al., 2009; Dawid et al., 1998).

As proteínas CRPs aparentam ter funções similares em diferentes tipos de células. CRP1 é expresso em diversos órgãos constituídos, em sua maioria, por células de músculo liso. O CRP2 expressa-se exclusivamente em artérias e fibroblastos, enquanto que, o CRP3 é expresso de forma predominante em órgãos compostos de músculo estriado (Campos et al., 2009). Ratos com deficiência na expressão de CRP3 apresentam alterações significativas nas F-actina que compõem o citoesqueleto celular, o que gera defeitos na arquitetura e funcionamento da musculatura estriada e que pode levar ao desenvolvimento de insuficiência cardíaca (Buyandelger et al., 2011; Campos et al., 2009; Arber et al., 1997). 
Dessa forma, a metodologia de análise desenvolvida foi aplicada nessas duas linhagens, WT e KO-CRP3. A primeira é considerada como uma amostra de célula saudável e a segunda, como uma amostra de célula com mau funcionamento do citoesqueleto, pois, a expressão do CRP3 foi bloqueada nessas amostras. A análise da dinâmica de forças foi realizada pela técnica de TFM e a metodologia de análise foi toda desenvolvida em ambiente MATLAB (maiores detalhes serão apresentados nos capítulos seguintes).

É indiscutível o fato do coração ser um órgão de suma importância para o bom funcionamento e saúde do corpo. O estudo in-vitro de seus componentes, especificamente os cardiomiócitos, é fundamental para o entendimento de suas funções e comportamento. Dessa maneira, acreditamos que o nosso trabalho pode formar uma base de conhecimento sólida nesse tipo de estudo e que, futuramente, possa colaborar com possíveis tentativas para o desenvolvimento de tecnologias relacionadas à regeneração cardíaca.

\subsection{Estrutura intracelular}

O comportamento mecânico das células depende da propriedade e do arranjo dos elementos estruturais, que podem ser vistos como uma rede fibrosa, ou rede de filamentos, coletivamente conhecida como citoesqueleto (Boal, 2002). A maioria dos filamentos estruturais na célula estão interligados para formar uma rede tridimensional, onde filamentos individuais constituintes desta rede se distribuem na célula de forma emaranhada, o que reflete, em parte, sua resistência ao ser flexionada (Boal, 2002). O citoesqueleto, juntamente com a membrana celular, fornece uma integridade estrutural para manter o formato da célula, muitas vezes necessário para que estas possam se comunicar entre si e realizar suas funções (Mofrad, 2009). Portanto, os filamentos do citoesqueleto, juntamente com outras estruturas, contribuem para a resposta da mecanotransdução, fenômeno este que envolve a sensibilidade da célula ao responder a um estímulo mecânico (Ingber, 2006).

A rede fibrosa do citoesqueleto, além de desempenhar um importante papel nas funções celulares, como migração, adesão e mecanotransdução, também é responsável pela rigidez da mesma (Safran et al. 2005). Os principais componentes da rede do citoesqueleto são os filamentos intermediários, os microtúbulos, as F-actina, e as ligações cruzadas de proteínas. Estes filamentos de proteínas são responsáveis por manter as 
propriedades estruturais e a motilidade celular (Mofrad, 2009; Mandadapu et al., 2008). Uma representação esquemática dos filamentos que compõe o citoesqueleto pode ser visto na Fig. 1.2 .

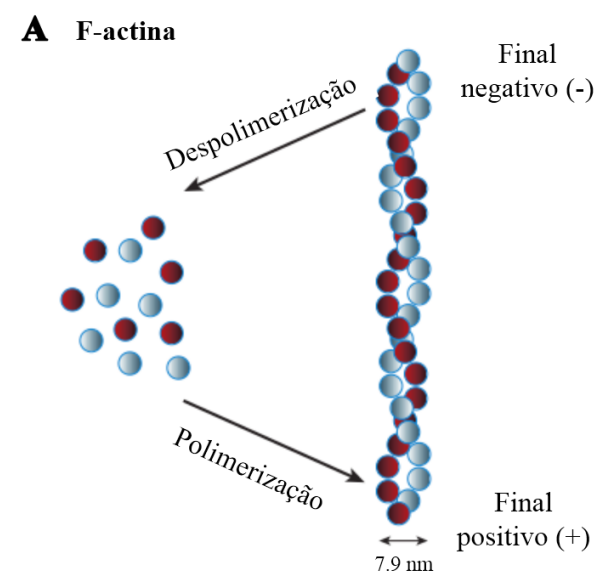

B Filamento intermediário
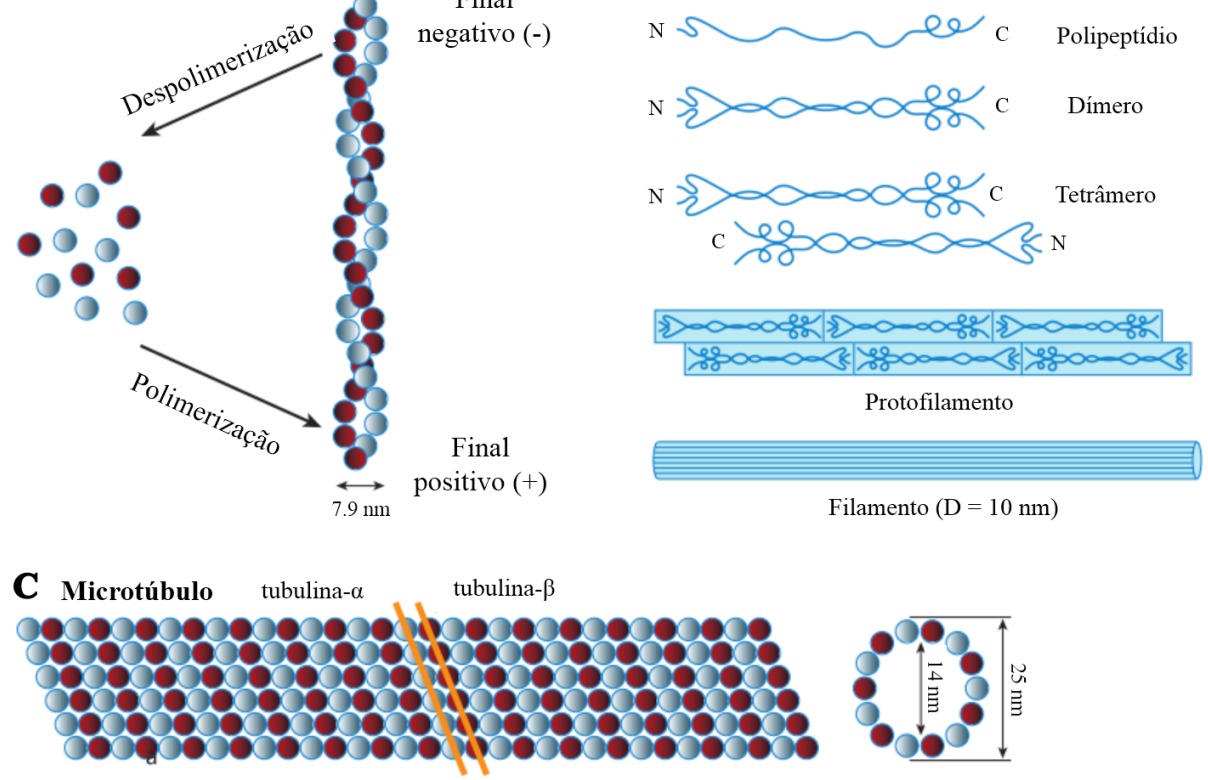

Figura 1.2: Principais componentes do citoesqueleto. Em A temos as F-actina, em B os filamentos intermediários e em C os microtúbulos (Figura adaptada de (Mofrad, 2009)).

Os filamentos intermediários são ligeiramente mais largos que as F-actina e possuem uma estrutura hierárquica mais complexa. Estes filamentos são compostos de diferentes monômeros de proteínas entrelaçados como uma hélice (Boal, 2002). Os dímeros se arranjam por ligações não covalentes em uma rede alternada de tetrâmeros conectados pelos seus pontos finais, formando assim, os protofilamentos, conforme Fig. 1.2. Estes, por sua vez, formam feixes em estruturas do tipo corda, contendo em torno de oito protofilamentos em formato quase cilíndrico com diâmetro de $10 \mathrm{~nm}$, aproximadamente (Mofrad, 2009; Boal, 2002). Os filamentos intermediários também contribuem para a elasticidade da célula. Sua rede exibe uma elasticidade não-linear pronunciada, similar a que é observada nas fibras de actina.

Os microtúbulos constituem outro importante componente do citoesqueleto e tem sido verificado seu envolvimento em uma variedade de processos celulares, atuando como um canal para condução dos motores celulares assim como, na organização da divisão celular (Mofrad, 2009). Os microtúbulos são polímeros ocos com diâmetro interno 
e externo de 14 e $25 \mathrm{~nm}$, respectivamente, compostos de monômeros de tubulina- $\alpha$ e $\beta$ em um arranjo helicoidal, conforme Fig.1.2 (Matsumoto e Nagayama, 2012). Muitas pesquisas foram feitas sobre as propriedades dos microtúbulos dentre as quais podemos destacar o modelo mecânico celular de Tensigrity, o qual se baseia na premissa de que os microtúbulos realizam compressão que balanceia o estresse contráctil exercido pelas F-actina dando estabilidade para a célula. Mais informações a respeito do modelo de Tensegrity e das funções dos microtúbulos e das F-actina podem ser encontradas nas referências (Ingber, 2003a b, 1993: Chen e Ingber, 1999; Canadas et al., 2002).

As F-actina são polímeros polares com uma torção helicoidal, com diâmetro de 7 a 9 $\mathrm{nm}$, e dois pontos finais que são extremamente diferentes, chamados de barbed e pointed. O ponto final barbed é o mais dinâmico e se alonga 10 vezes mais rápido que o final, pointed (Blanchoin et al., 2014). A actina é vista como sendo o componente estrutural primário das células, constituindo $10 \%$ de toda proteína da maioria das células (Mofrad, 2009). Sua alta concentração celular torna-a a proteína mais abundante da Terra (Pollard e Cooper, 2009). As F-actina são essenciais para dar suporte mecânico interno para a célula, fornecendo caminhos para a movimentação interna de materiais e dando força para locomoção celular. A Fig. 1.3 mostra de forma esquemática os tipo de filamentos que são polimerizados pelas F-actina e os diferentes tipos de redes que são formadas, como: as organizações ramificadas e reticuladas, os feixes paralelos, e as estruturas anti-paralelas contráteis.

As proteínas de ligações cruzadas ligam as F-actina umas às outras formando géis elásticos ou conjuntos de estruturas tais como: fibras de estresse e filopódia (Kasza et al. 2010). Seus filamentos são rígidos, tendo um comprimento de persistência na ordem de aproximadamente $10 \mu m$ em solução aquosa, e um efetivo módulo de Young, determinado pela sua rigidez de deflexão e raio (Mofrad, 2009). 


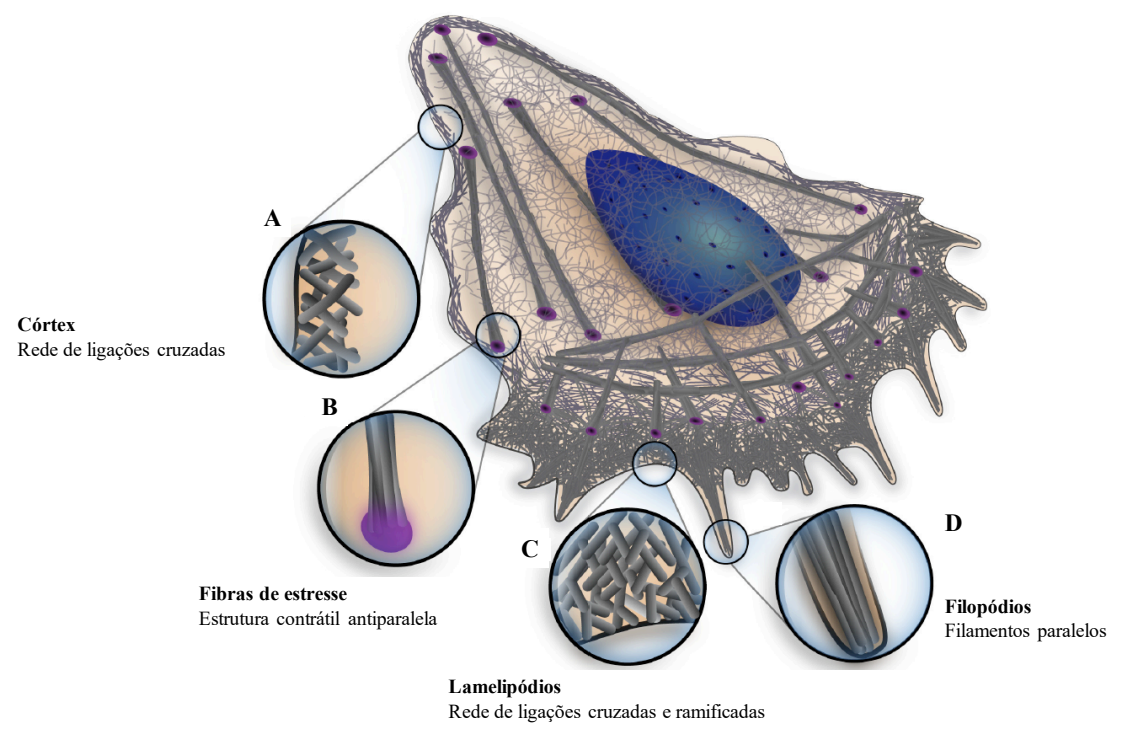

Figura 1.3: Representação esquemática da arquitetura da rede de actina na célula. Filopódio. As regiões com zoom, em destaque mostram especificidades arquitetônicas de diferentes regiões da célula, que são: (A) córtex celular; (B) exemplo de uma fibra contrátil, as fibras de estresse; (C) Lamelipódio; (D) filopódio (Figura adaptada de (Blanchoin et al. 2014)).

O lamelopódio é composto pelas ramificações e redes de ligações transversais na região frontal da célula e é o principal motor de movimentação celular (Fig.1.3 C). Os filopódios, feixes alinhados subjacentes, são estruturas semelhantes a dedos, localizados na parte frontal das células e são importantes para a resposta direcional das mesmas (Fig.1.3 D). O córtex celular, que é uma fina camada de actina, reveste a membrana plasmática pelos lados e pela parte de trás da célula, e é importante para a manutenção da estrutura celular e para manutenção de sua forma (Fig.1.3A). O restante da célula contém uma rede tridimensional de filamentos reticulados, intercaladas com feixes contráteis, incluindo as fibras de estresse que ligam o citoesqueleto celular à matriz extracelular, através dos locais de adesão focal (Fig.1.3 B) (Blanchoin et al. 2014).

A contração na célula é produzida pela interação actina-miosina, que funciona como um motor molecular. A miosina se acopla em mini-filamentos antissimétricos que, uma vez incorporada dentro de uma rede de actina, provocam deslizamento dos filamentos de actina, contração celular e tensão em sítios de adesão focal (Blanchoin et al., 2014). A Fig.1.4 mostra de forma esquemática, através de molas e amortecedores ativamente interligados, os elementos mecânicos responsáveis por conduzir as alterações da forma e da motilidade celular (Blanchoin et al., 2014). 


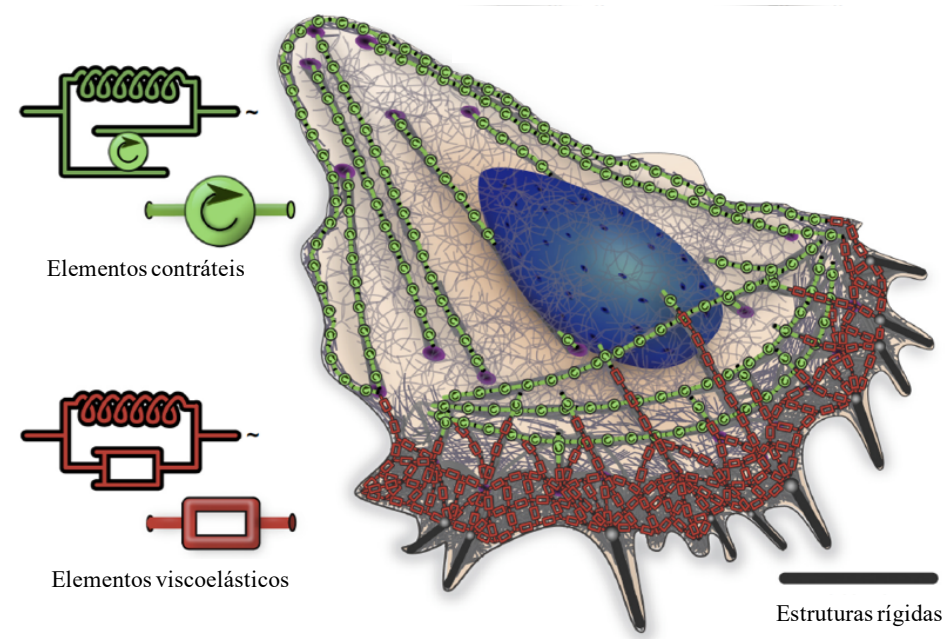

Figura 1.4: Representação esquemática do perfil mecânico da rede de actina. Os retângulos vermelhos são os amortecedores que representam a rede de actina, enquanto que os círculos verdes representam molas ativas devido à atividade motora da miosina (Figura adaptada de (Blanchoin et al., 2014)).

Para construir uma variedade de arquiteturas diferentes, as células utilizam uma gama de proteínas que geram a rede de actina e controlam a resposta mecânica do citoesqueleto. Por sua vez, sinais mecânicos controlam a atividade bioquímica das F-actina e das proteínas que se ligam à actina. Devido à importância da actina e dos demais filamentos que compõem o citoesqueleto celular, o conhecimento básico de sua reologia é essencial para o entendimento de suas propriedades mecânicas. Portanto, aprofundaremos o conceito de reologia e a aplicação de técnicas experimentais para o estudo da mecânica do citoesqueleto, especificamente na técnica de microscopia de força de tração.

\subsection{Microrreologia celular}

Em décadas recentes, diversos modelos de mecânica dos fluídos foram desenvolvidos para o estudo de células vivas. Isso só foi possível devido ao grande avanço na área de Biologia Molecular (Kamm, 2002). O comportamento mecânico da fluidez celular e seus efeitos biológicos são temas que englobam diversos campos de pesquisa, tais como: Biofísica, Bioengenharia, Fisiologia, Física e Biologia (Kamm, 2002). O estudo da deformação e fluidez da matéria faz parte de um campo de pesquisa chamado reologia. Basicamente, a reologia é o estudo de como materiais complexos fluem e se 
deformam sob algum tipo de estresse (Barnes et al., 1989; Squires e Mason, 2010). As propriedades reológicas de materiais complexos além de determinar seu comportamento fluido, fornecem informações sobre seus componentes microestruturais (Squires e Mason, 2010).

Fluidos newtonianos simples têm como principal característica a tensão ser proporcional à taxa de deformação, além de apresentarem uma viscosidade e elasticidade desprezíveis. Sólidos hookeanos simples não fluem e são caracterizados por um módulo elástico. Tanto os fluidos newtonianos como os sólidos hookeanos apresentam limitações que impossibilitam descrever diversos materiais considerados macios (soft), que são tanto viscosos quanto elásticos sobre a escala de tempo em que são detectados (Breuer, 2005). Esses tipos de materiais são chamados de viscoelásticos e, têm sido estudados com reômetros mecânicos, em várias geometrias de deformação, dependendo da extensão de deformação e magnitude dos módulos a serem medidos (Breuer, 2005). No entanto, as técnicas mecânicas reológicas convencionais nem sempre são adequadas para descrever o comportamento da maioria desses tipos de materiais, pois é necessário um volume de amostra na escala de mililitros, impedindo o estudo de muitas amostras biológicas, que são difíceis de se obter em grandes quantidades (Breuer, 2005).

Devido a esse fato, diversas técnicas microrreológicas foram desenvolvidas principalmente para o estudo de células vivas. Com essas técnicas foi possível superar algumas limitações das técnicas de reologia tradicional, tais como a faixa de frequência e o módulo que podem ser sondados, o tamanho da amostra, heterogeneidade, entre outros (Cicuta e Donald, 2007). O termo micro se refere ao tamanho da sonda de tensão/deformação, que fica tipicamente na escala dos mícrons, além de indicar que as técnicas de microrreologia podem ser realizadas em volumes muito pequenos, com amostras em microlitros. As vantagens oferecidas por essas técnicas fizeram com que elas se popularizassem na última década, e abriram novos campos de investigação (Cicuta e Donald, 2007).

Nesse contexto, determinar como um material responde a um estímulo mecânico, depende de um grupo de características chamadas de propriedades mecânicas do material (Moeendarbary e Harris, 2014). São essas propriedades mecânicas que descrevem como um material se deforma em resposta a um estresse aplicado, e como essa deformação evolui ao longo do tempo (Moeendarbary e Harris, 2014). A razão entre tensão e deformação relativa de um material é uma constante chamada de módulo de Young (geralmente se 
refere a elasticidade do material, em unidades de pascal) (Tipler e Mosca, 2000; Moeendarbary e Harris, 2014). A Fig. 1.5 mostra o valor do módulo de Young para alguns materiais. Nela, podemos ver que a célula é extremamente mole, com um módulo de Young de muitas ordens de grandeza menor do que a maioria dos materiais comuns.
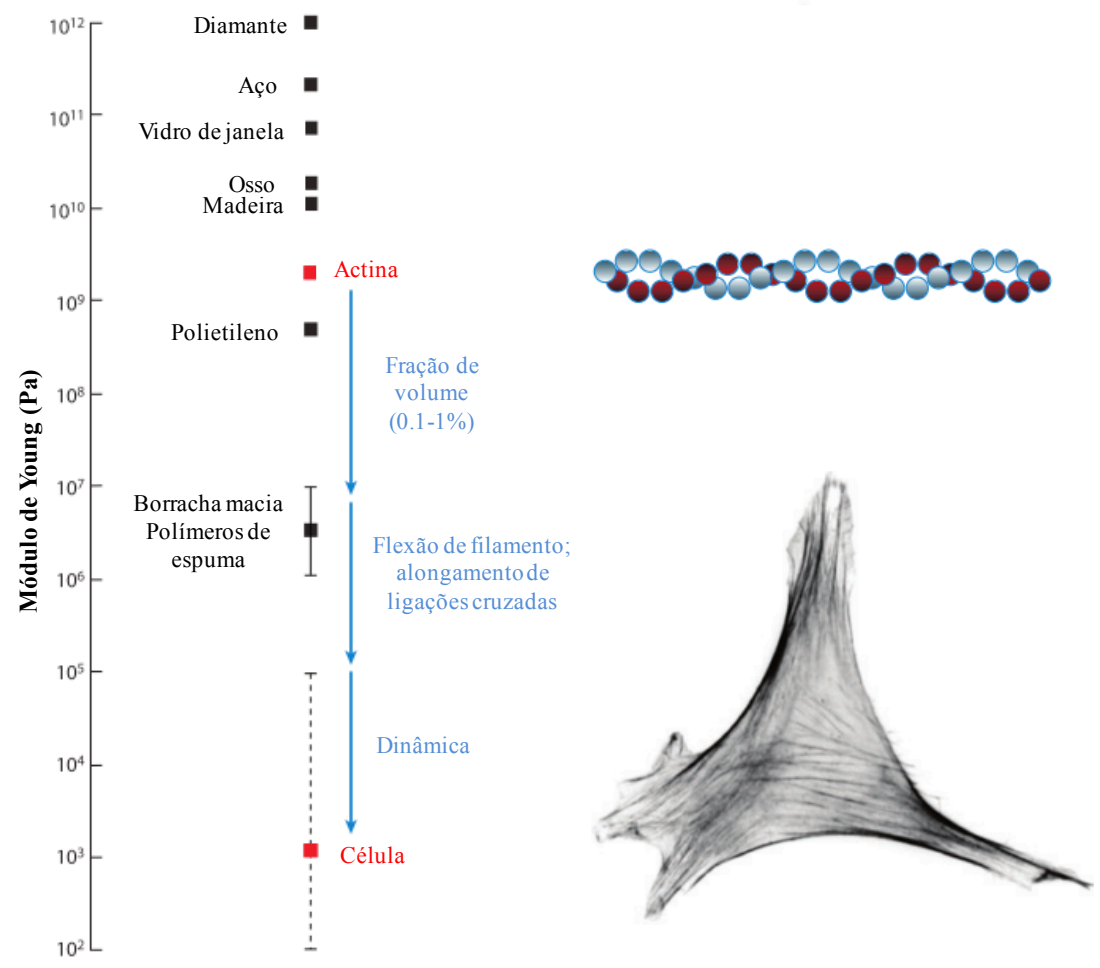

Figura 1.5: Módulo de Young de alguns materiais comuns. A célula apresenta um módulo de Young muitas ordens de grandeza menor do que alguns materiais típicos, o que a torna extremamente mole. A fibra de actina, isoladamente, tem uma alta rigidez e é a principal proteína que constitui a célula, entretanto, quando colocada no formato de malha conectada com outros componentes do citoesqueleto, forma uma estrutura com a rigidez de géis moles. A imagem acima corresponde ao citoesqueleto de uma célula de fibroblastos NIH-3T3 (imagem adaptada de (Kollmannsberger e Fabry, 2011)).

O módulo de Young é uma propriedade fundamental de materiais sólidos e determina a capacidade que o material tem de sustentar sua forma quando submetido a um estresse mecânico. No entanto, materiais elásticos, quando submetidos a um estresse mecânico, são capazes de armazenar energia elástica (Kollmannsberger e Fabry, 2011; Moeendarbary e Harris, 2014). A taxa de fluidez desses materiais, quando submetidos a algum tipo de carga, é dada por sua viscosidade (geralmente com unidade de pascal por segundo).

Quando se compara o comportamento de células vivas com o de materiais elásticos 
e viscosos submetidos a um estresse mecânico, verifica-se que as células apresentam ambas as propriedades, elástica e viscosa, sendo então, consideradas como materiais viscoelásticos (Kollmannsberger e Fabry, 2011; Moeendarbary e Harris, 2014). Devido à baixíssima rigidez e pequeno tamanho da célula, as forças mecânicas e as deformações são muito pequenas, na faixa de pico-Newtons e nanômetros, respectivamente (Kollmannsberger e Fabry, 2011). Quando materiais moles, a esse nível, cerca de $10^{3} \mathrm{~Pa}$ (Fig. 1.5), são tensionados, suas microestruturas, tanto armazenam quanto dissipam a energia de deformação de uma forma que pode depender da frequência, fazendo com que, neste caso, a viscosidade e a elasticidade também dependam.

O grande interesse no entendimento das propriedades mecânicas das células levou ao desenvolvimento de novas técnicas experimentais e teóricas para a medição e análise dessas propriedades, tendo em vista que, alterações em tais propriedades celulares acarretam modificações microestruturais que podem afetar o crescimento de tecido (Heisenberg e Bellaïche, 2013; Shraiman, 2005), formação de tubos vasculares (Hannezo et al., 2012: Lubarsky e Krasnow, 2003), migração celular (Alford et al., 2011; Gerthoffer, 2007), assim como levar a quadros patológicos (Katira et al., 2012; Coughlin et al., 2013). Dentre as técnicas de microrreologia para análise da mecânica celular, destaca-se: o método da pinça óptica (Buehler e Yung, 2009: Lim et al., 2006), microscopia de força atômica (AFM) (Ludwig et al., 2008; Discher et al., 2005: Kamm, 2002; Moeendarbary e Harris, 2014), citometria óptica de torção magnética (OMTC) (Coughlin et al., 2013: Fabry et al., 2001; Kollmannsberger e Fabry, 2011; Mofrad, 2009), microscopia de força de tração (TFM) (Butler et al., 2002; Ingber, 2003a; Gavara et al., 2008), entre outras. A Fig.1.6ilustra esquematicamente algumas dessas técnicas.

A AFM é uma técnica de caracterização de superfície de alta resolução e tem sido amplamente utilizada para obtenção de imagens e caracterização mecânica de uma variedade de amostras biológicas (Müller e Dufrene, 2010; Moeendarbary e Harris, 2014). A técnica de AFM utiliza uma ponta conectada a um cantiléver que interage com a amostra. Uma das formas mais utilizadas do AFM no estudo da mecânica celular é para medidas da elasticidade e reologia celular (Moeendarbary e Harris, 2014). Para obtenção da elasticidade celular, a ponta do cantiléver do AFM é pressionada contra a célula enquanto que a força e a deformação gerada na célula é monitorada (Alcaraz et al., 2003: Qiu et al., 2010; Moeendarbary e Harris, 2014). 

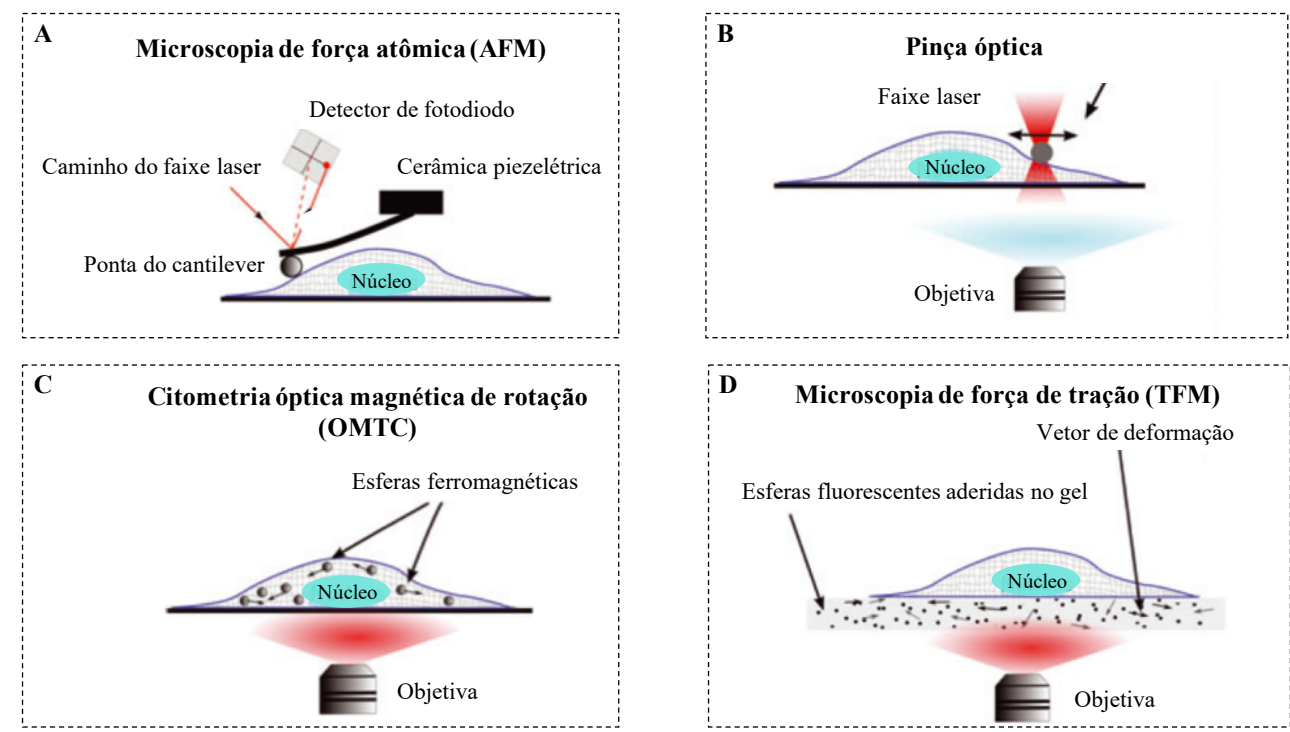

Figura 1.6: Representação esquemática de quatro técnicas de microrreologia. A Microscopia de força atômica (AFM): um feixe laser é refletido na parte de trás do cantiléver e detectado pelo fotodiodo. A interação entre a ponta e a amostra altera a flexão do cantiléver e, consequentemente, o caminho de reflexão do feixe laser que é precisamente mensurado pelos fotodiodos. A deflexão do cantiléver é convertida em força usando a constante da mola. B Pinça óptica: Uma pequena partícula é presa de forma estável por um feixe laser altamente focalizado. A posição da partícula pode ser controlada pelo movimento da armadilha óptica e pequenas forças podem ser estimadas pela mudança na posição da partícula pelo centro da armadilha óptica. C Citometria óptica de torção magnética (OMTC): microesferas ferromagnéticas aderidas ao citoesqueleto celular ficam sujeitas a um campo magnético externo oscilatório. As microesferas se alinham ao campo magnético e rotacionam conforme o campo oscila. Essa rotação gera um torque na célula que é monitorada ao longo do tempo. Dessa forma é possível obter o módulo viscoelástico da célula. D Microscopia de força de tração (TFM): A célula é aderida a um gel flexível de poliacrilamida, com módulo elástico conhecido, onde beads fluorescentes são aderidos em sua superfície. Para as células se aderem ao gel, elas realizam forças que o deformam e deslocam beads fluorescentes. Pelo monitoramento do deslocamento dos beads é possível estimar a força de tração que as células fazem (imagem adaptada de (Moeendarbary e Harris, 2014)).

Devido ao interesse crescente no estudo da mecânica celular, diversas técnicas experimentais que utilizam armadilhas ópticas foram desenvolvidas para manipulação ou estiramento de partes da célula, sendo uma delas a pinça óptica (Moeendarbary e Harris, 2014). Essa técnica parte do conceito de que quando a luz penetra um meio com índice de refração diferente, ela muda seu caminho. A conservação do momento significa que é criada uma força restauradora pela luz, passando através do material que resiste a níveis mais altos de refração (Moeendarbary e Harris, 2014). Dessa forma, é possível capturar ou deformar uma pequena partícula ou uma célula opticamente e ser 
manipulada por uma fonte de luz colimada. Devido a alta sensitividade (resolução de pico-Newton) e alta precisão espaço-temporal, essa técnica tem sido bem utilizada em medidas sub-celulares. Algumas das pesquisas científicas envolvendo a técnica de pinça óptica estão relacionadas a tensão de deformação da membrana extracelular de diversos tipos de células (Hochmuth et al., 1996; Raucher e Sheetz, 1999: Moeendarbary e Harris, 2014).

Na técnica de OMTC, microesferas ferromagnéticas de $4.5 \mu \mathrm{m}$ de diâmetro recobertas com um peptídeo sintético, contendo uma sequência adesiva de três aminoácidos, arginine-glycine-aspartic acid (RGD), são depositadas sobre as células e se aderem fortemente ao citoesqueleto por meio de receptores (integrinas) na sua superfície (Fabry et al., 2001: Moriya et al. 2008). A sequência RGD é comum a várias proteínas da matriz extracelular e é reconhecida pelas células por meio dos receptores. Estes, além de iniciarem uma sinalização bioquímica, também apresentam uma ligação física ao citoesqueleto de actina.

Inicialmente as microesferas são magnetizadas horizontalmente, para em seguida serem realizadas as medidas, impondo um campo magnético vertical homogêneo, externamente, que varia senoidalmente no tempo. A aplicação deste campo gera um torque que causa a rotação das microesferas no sentido de se alinharem ao campo. Esta rotação é impedida, contudo, pelas forças mecânicas que se desenvolvem dentro das células, em resposta a rotação das esferas. $\mathrm{O}$ torque gerado nas microesferas, devido ao campo magnético externo, desloca lateralmente as esferas durante a sua rotação em resposta ao torque oscilatório. O movimento forçado das microesferas é modulado através das propriedades elásticas e viscosas do esqueleto celular. Com isto é possível medir o módulo complexo de cisalhamento, como uma função da frequência devido ao campo magnético oscilatório aplicado (Fabry et al., 2001: Moriya et al., 2008).

A técnica de OMTC pode ser utilizada para explorar as propriedades dinâmicas do esqueleto celular ao longo de um amplo intervalo de frequência, de 0.1 a $1 \mathrm{kHz}$, assim como, pode ser aplicada a uma grande variedade de células, incluindo células do músculo liso, células endoteliais e epiteliais (Fabry et al., 2001; Kollmannsberger e Fabry, 2011; Mofrad, 2009; Puig-de Morales et al., 2004). Essa é uma das técnicas que se encontra acessível em nosso laboratório $\left(\mathrm{LabM}^{2}\right)$, e diversos alunos de pós graduação a utilizam para investigação da mecânica celular, além de algumas dessas investigações já 
terem resultado em publicações (Dinardo et al., 2013, 2012).

Por fim, na técnica de TFM, basicamente as células realizam adesões focais em substratos flexíveis com microesferas fluorescentes aderidas próximas a superfície do substrato. Conforme as células se contraem, elas deformam o substrato e, com isso, alteram a posição das microesferas fluorescentes. Uma vez que se conhece a rigidez do substrato, é possível obter a força de tração necessária para realizar uma determinada deformação pelo deslocamento das microesferas fluorescentes (Kijlstra et al., 2015; Butler et al., 2002).

O desenvolvimento destas técnicas experimentais levou à criação de uma vasta gama de modelos matemáticos para descrever a microrreologia do citoesqueleto e sua mecânica (Mofrad, 2009). Estas técnicas experimentais frequentemente induzem uma perturbação mecânica na célula, impondo uma deformação ou aplicando uma força e observando a resposta da célula. Isto deu origem a uma série de teorias para descrição da mecânica de células vivas e modelagem do seu citoesqueleto, tais como: os modelos mecânicos elásticos, viscoelásticos e porosos (Lim et al., 2006; Mofrad, 2009; Yamaoka et al., 2012; Kasza et al., 2010; Kardas et al., 2013); modelos baseados na teoria de materiais vítreos moles (SGM do inglês soft glassy material) (Lim et al., 2006; Vaziri et al., 2007; Mandadapu et al., 2008); modelo de Tensegriy, que parte da premissa da existência da pré-tensão celular exercidas pelo citoesqueleto (Canadas et al., 2002; Ingber. 2003b, 1993); modelos baseados na teoria de percolação na qual os filamentos que compõem o citoesqueleto devem estar conectados de uma extremidade a outra da célula, para que esta possa exercer suas funções mecânicas (Mofrad, 2009; Silveira et al., 2009).

Esses diversos modelos propiciaram um maior entendimento das propriedades mecânicas das células. Com isso, percebeu-se a importância de se quantificar as forças de tração exercidas pelas células. Isso porque, processos celulares importantes, como, migração, contração e relaxamento, metástase, adesão celular, entre outros, são gerados pelas forças de trações que as células exercem em um substrato (Tang et al., 2014; Style et al., 2014). A técnica micorreológica utilizada em nosso trabalho para o estudo das propriedades mecânicas dos cardiomiócitos foi o TFM, por ser a técnica disponível em nosso laboratório que mais se adequara às nossas necessidades. Logo, a técnica de TFM será melhor descrita no próximo capítulo. 


\section{Capítulo 2}

\section{Técnicas experimentais}

Nesse capítulo serão descritos os detalhes da metodologia empregada para a realização do experimentos com os cardiomiócitos. A forma com que células vivas interagem com o microambiente que as rodeia é através de forças de tração. Essa interação celular, conhecida como mecanotransdução, é fundamental para que a célula sobreviva e consiga realizar suas funções corretamente, pois, é pela mecanotransdução que as células se comunicam umas com as outras e com seu microambiente (Tang et al. 2014: Wang e Li, 2010). Pelas forças de tração, as células são capazes de sentir as propriedades mecânicas do seu microambiente, como por exemplo, células vizinhas e substrato, e ajustar suas adesões focais, morfologia, motilidade, dentre diversas outras funções de acordo com o meio na qual se encontram (Butler et al., 2002; Wang e Li, 2010). Para que fosse possível obter dados relacionados à dinâmica de forças durante o ciclo de contração dos cardiomiócitos, foi utilizada a técnica de TFM.

Dessa forma, conseguir caracterizar de maneira precisa o campo de forças de tração exercido pela célula em um substrato, sob diversas condições fisiológicas, é fundamental para o entendimento da mecanotransdução entre diversos tipos celulares e seu microambiente (Tang et al. 2014). A seguir, será descrito os detalhes de como são obtidas as forças de tração exercidas pela célula com a técnica de TFM.

\subsection{Microscopia de força de tração}

Nessa técnica, as células aderem-se a um substrato flexível com marcadores fluorescentes, beads, que são identificados por um microscópio de fluorescência, onde é possível monitorar seus deslocamentos por softwares computacionais e, dessa forma, se obter 
o campo de tração gerado no substrato. Um dos trabalhos pioneiros na tentativa de visualizar as forças de tração celular foi realizado em 1980 por Harris e colaboradores, no qual os autores utilizaram uma camada fina de substrato de silicone polimérico e observaram o enrugamento causado no substrato pela migração das células (Harris et al., 1980). No entanto, foi a partir de 1995 que Dembo e Wang, assim como outros pesquisadores, desenvolveram as técnicas de TFM e mostraram que o campo de forças de tração exercida pela célula em sua vizinhança podia ser mapeado, desde que fosse conhecido o campo de deslocamento em um substrato flexível no qual as células estavam aderidas (Dembo e Wang, 1999; Butler et al., 2002; Tang et al., 2014).

Para isso, era necessário, inicialmente, conhecer as propriedades elásticas do substrato, como por exemplo, sua rigidez, e colocar um marcador nesse substrato para se quantificar o deslocamento. Geralmente utiliza-se um substrato de gel de poliacrilamida, desenvolvido por Pelham e Wang, cuja rigidez pode ser ajustada por meio da proporção entre monômeros de acrilamida e o crosslinker bisacrilamida (Pelham Jr e Wang, 1998). Para o caso de uma célula de músculo liso, o substrato pode ter rigidez de $5 \mathrm{kPa}$, enquanto que, para cardiomiócitos a rigidez fica em torno de $10 \mathrm{kPa}$ (Yeung et al., 2005; Engler et al. 2008). Para se quantificar o campo de deslocamento, utiliza-se microesferas fluorescentes, na ordem de $0.2 \mu \mathrm{m}$ de diâmetro, embutidas próximas à superfície do substrato de gel, que servem como marcadores da deformação sofrida no gel devido às forças de tração exercidas pela célula. A Fig.2.1 exemplifica como a célula interage com o gel flexível utilizado no TFM.

Para medir o campo de deslocamento são necessárias, no mínimo, duas imagens. Uma delas é da célula aderida ao substrato, exercendo força de tração, e a outra é apenas do substrato sem célula (imagem de referência). A primeira fornece a configuração da deformação da superfície do substrato. A segunda imagem mostra a configuração dos marcadores fluorescentes sem deformação, com o substrato livre das forças de tração (Tang et al. 2014). Para isso, é necessário remover as células por processo de tripsinização (McNeil et al., 1984; Brown et al., 2007). A tripsina é uma enzima produzida no pâncreas, capaz de quebrar ligações peptídicas das células com o substrato. Comparando a diferença de posição das microesferas nas duas imagens, é possível a obtenção do campo de deslocamento dos beads fluorescentes no substrato. 

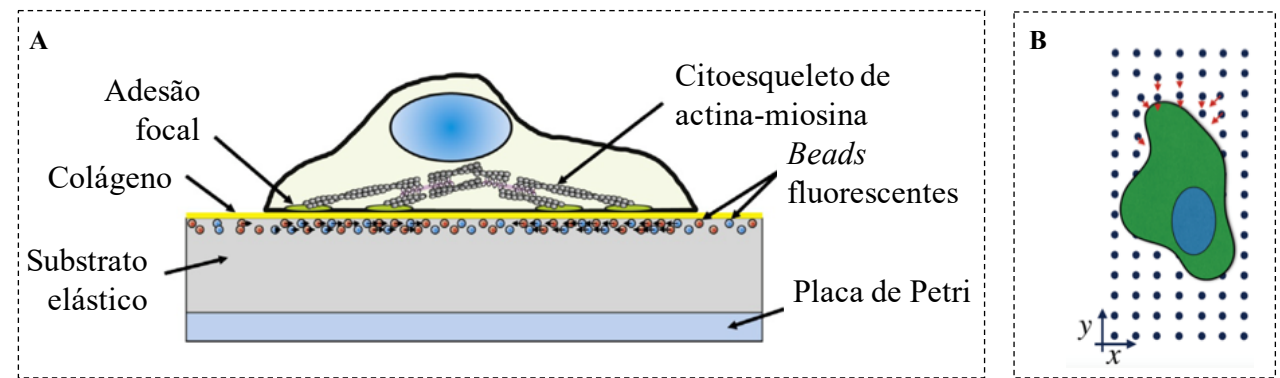

Figura 2.1: A: esquema da interação da célula com o substrato flexível do TFM. A célula, quando aderida ao substrato, realiza adesões focais que produzem as forças de tração que deslocam os beads fluorescentes, alterando suas posições iniciais (imagem adaptada de (Plotnikov et al. 2014)). B: Esquema da vista superior do campo de deslocamento dos beads produzido pelas forças de tração exercidas pela célula.

Na técnica de TFM, o campo das forças de tração é definido como força por unidade de área, $\mathrm{Pa}=\mathrm{N} / \mathrm{m}^{2}$, gerada na superfície do gel pela célula aderida (Butler et al. 2002). Esse campo deforma o substrato e essa deformação é geralmente descrita por um gradiente de deformação $\mathbf{F}$, que nada mais é do que o Jacobiano da transformação de coordenada, de um estado não deformado $\mathbf{x}$, para um estado deformado x' (Schwarz e Soiné 2015). O tensor $\mathbf{F}$ é descrito da seguinte forma:

$$
\mathbf{F}=\left(\begin{array}{lll}
\frac{\partial x^{\prime}}{\partial x} & \frac{\partial x^{\prime}}{\partial y} & \frac{\partial x^{\prime}}{\partial z} \\
\frac{\partial y^{\prime}}{\partial x} & \frac{\partial y^{\prime}}{\partial y} & \frac{\partial y^{\prime}}{\partial z} \\
\frac{\partial z^{\prime}}{\partial x} & \frac{\partial z^{\prime}}{\partial y} & \frac{\partial z^{\prime}}{\partial z}
\end{array}\right)
$$

Chamando o vetor deslocamento de $\mathbf{u}=\mathbf{x}^{\prime}-\mathbf{x}$, é possível reescrever o tensor $\mathbf{F}$ da seguinte forma:

$$
\mathbf{F}=\mathbf{1}+(\nabla \otimes \mathbf{u})^{T},
$$

sendo, 1 o tensor unidade, $\otimes$ o produto vetorial, $\nabla$ o operador nabla e $(\nabla \otimes \mathbf{u})^{T}$ a matriz transposta de $(\nabla \otimes \mathbf{u})$.

Os campos espaciais $\mathbf{F}$ e $\mathbf{u}$ são utilizados para se medir mudanças locais no deslocamento e na angulação durante a deformação (Schwarz e Soiné, 2015). No entanto, esses campos devem ser obtidos pelas imagens de microscopia de fluorescência do TFM. Para isso, pode-se utilizar o tensor de Green-Lagrange para se obter a deformação, E, da seguinte forma: 


$$
\mathbf{E}=\frac{1}{2}\left(\mathbf{F}^{T} \cdot \mathbf{F}-\mathbf{1}\right)
$$

O tensor $\mathbf{E}$ pode ser reescrito em termos do vetor deslocamento $\mathbf{u}$, substituindo $\mathbf{F}$ pela expressão da Eq. (2.2), da seguinte forma:

$$
\mathbf{E}=\frac{1}{2}\left[(\nabla \otimes \mathbf{u})+(\nabla \otimes \mathbf{u})^{T}+(\nabla \otimes \mathbf{u})(\nabla \otimes \mathbf{u})^{T}\right] .
$$

Nessa expressão, o termo $(\nabla \otimes \mathbf{u})(\nabla \otimes \mathbf{u})^{T}$ é a contribuição não linear do tensor $\mathbf{E}$ (Schwarz e Soiné, 2015). No entanto, para pequenas tensões, a contribuição não linear pode ser desprezada e o tensor $\mathbf{E}$ se torna um tensor de deformação linear, que pode ser escrito da seguinte forma:

$$
\epsilon=\frac{1}{2}\left[(\nabla \otimes \mathbf{u})+(\nabla \otimes \mathbf{u})^{T}\right]
$$

sendo, as componentes do tensor linear $\epsilon$ :

$$
\epsilon_{i j}=\frac{1}{2}\left(\frac{\partial u_{i}}{\partial x_{j}}+\frac{\partial u_{j}}{\partial x_{i}}\right) .
$$

Para que essa relação linear seja válida, o substrato flexível deve ser isotrópico e a deformação na superfície do gel deve ser $u_{i}<1 \mu \mathrm{m}$ (Plotnikov et al., 2014). Dessa forma, considerando o substrato flexível como homogêneo, isotrópico e elástico, a tensão $\sigma$ sobre a superfície pode ser escrita em função da deformação linear, $\epsilon$, da seguinte forma (Plotnikov et al., 2014):

$$
\sigma_{i j}=\frac{E}{1+s}\left[\epsilon_{i j}+\frac{s}{1-2 s} \delta_{i j}\left(\epsilon_{i i}+\epsilon_{j j}+\epsilon_{k k}\right)\right],
$$

sendo, $\delta_{i j}$ a função delta de Kronecker, E o módulo de Young e $s$ o raio de Poisson, parâmetros esses que dependem do tipo de material de que é feito o substrato.

As células aderidas ao substrato aplicam forças de tração somente na superfície, $z=0$. Com isso, as forças internas no substrato são desprezíveis, restando apenas as forças tangenciais aplicadas pela célula na superfície (plano $x y$ ) (Plotnikov et al., 2014; Schwarz e Soiné, 2015). As forças aplicadas pela célula são equilibradas pelas forças tangenciais do substrato, pois as forças verticais (plano $z x$ ) são desprezíveis para $z=0$. Dessa forma, é comum considerar o substrato com extensão infinita no plano $x y$ e se estendendo de $z=0$ até $z=-\infty$ (Plotnikov et al., 2014). 
Nos experimentos de TFM, o substrato de poliacrilamida utilizado tem espessura típica de $50 \mu \mathrm{m}$, entretanto, pode-se desprezar as tensões verticais e manter as condições de contorno, descritas acima. Satisfazendo essas condições de contorno, é possível utilizar o formalismo da função de Green, $\mathbf{G}\left(\mathbf{x}, \mathbf{x}^{\prime}\right)$, para calcular as trações exercidas na superfície do substrato $\mathbf{t}\left(\mathbf{x}^{\prime}\right)$, pela seguinte integral de convolução:

$$
\mathbf{u}(x)=\int \mathbf{G}\left(\mathbf{x}, \mathbf{x}^{\prime}\right) \mathbf{t}\left(\mathbf{x}^{\prime}\right) d \mathbf{x}^{\prime}
$$

A função de Green na equação acima é uma matriz $3 \times 3$ que descreve os deslocamentos no material em três dimensões. Para que os deslocamentos possam ser tratados apenas em duas dimensões, o raio de Poisson deve ser $s \approx 0.5$. No entanto, como descrito acima, o substrato de poliacrilamida utilizado nos experimentos de TFM, possue um raio de Poisson em torno de $s \approx 0.45$. Com isso, pode-se tratar os deslocamentos no substrato do TFM apenas em duas dimensões (Schwarz e Soiné, 2015). A função de Green em duas dimensões é escrita da seguinte forma (Landau e Lifshitz, 1986; Butler et al., 2002):

$$
\mathbf{G}(\mathbf{x})=\frac{A}{r^{3}}\left(\begin{array}{cc}
(1-s) r^{2}+s x^{2} & s x y \\
s x y & (1-s) r^{2}+s y^{2}
\end{array}\right),
$$

sendo, $A=(1+s) / \pi E$ e $r=\sqrt{x^{2}+y^{2}}$.

Para que seja possível obter as forças de tração a partir dos deslocamentos, preciso inverter a integral de convolução da Eq. (2.8). Essa inversão pode ser resolvida com a função de Green, tanto no espaço real, quanto no espaço de Fourier (Schwarz e Soiné, 2015). Dessas duas opções, a inversão no espaço de Fourier é muito mais simples e, em termos computacionais, o processamento é muito mais rápido. Assim, a inversão foi realizada no espaço de Fourier pela técnica de FTTC (do inglês Fourier Transform Traction Cytometry) (Schwarz e Soiné, 2015; Butler et al., 2002). No espaço de Fourier, as convoluções das funções se transformam no produto das transformadas de Fourier de cada função. De forma que, a Eq. (2.8) pode ser reescrita no espaço de Fourier da seguinte forma:

$$
\tilde{\mathbf{t}}(k)=\tilde{\mathbf{G}}(k)^{-1} \tilde{\mathbf{u}}(k),
$$

na qual, o til denota a transformada de Fourier, e a função de Green em duas dimensões no espaço de Fourier fica da seguinte forma: 


$$
\tilde{\mathbf{G}}(k)=\frac{A}{k^{3}}\left(\begin{array}{cc}
(1-s) k^{2}+s k_{x}^{2} & s k_{x} k_{y} \\
s k_{x} k_{y} & (1-s) k^{2}+s k_{y}^{2}
\end{array}\right) .
$$

Atualmente, a técnica de FTTC é amplamente utilizada para reconstrução das forças de tração, principalmente por ter um processamento computacional rápido e de precisar apenas da informação referente ao campo de deslocamento dos beads fluorescentes (Schwarz e Soiné, 2015). Por isso, essa foi a técnica por nós utilizada para obtenção das forças de tração da célula no substrato. As imagens utilizadas para o processamento do campo de deslocamento foram obtidas por um microscópio de fluorescência, e o funcionamento básico desse tipo de microscopia será descrito a seguir.

\subsection{Microscopia de fluorescência}

As células são estruturas complexas, de difícil acesso para visualizar seus componentes estruturais e como eles funcionam. As técnicas e ferramentas à nossa disposição hoje, nos ajudam a aprender mais sobre as células e a impulsionar o avanço na área de biologia celular (Alberts et al. 2010). Uma das primeiras técnicas que possibilitou o avanço no entendimento da organização estrutural celular foi o microscópio óptico. Uma das grandes vantagens de se usar essa técnica é que a luz não causa danos significativos à célula (Alberts et al. 2010).

O avanço na microscopia óptica ocorreu com o desenvolvimento de metodologias capazes de marcar componentes específicos das células e gerar imagens individuais desses componentes. Essa identificação de componentes específicos da célula ocorre por meio de marcadores fluorescentes que se aderem por afinidade química aos componentes que se deseja observar. O desenvolvimento dessa metodologia gerou a técnica de microscopia de fluorescência (Alberts et al. 2010).

Esse tipo de microscópio, geralmente utiliza uma lâmpada de gás de alta pressão, com potência de $100 \mathrm{~W}$ de mercúrio ou de $75 \mathrm{~W}$ de xénon. Sua principal diferença para um microscópio óptico comum é que o feixe de luz proveniente da fonte passa por dois conjuntos de filtros. O primeiro serve para deixar passar apenas o comprimento de onda necessário para excitar o marcador fluorescente e, o segundo, para deixar passar apenas o comprimento de onda emitido pelo marcador fluorescente (Alberts et al., 2010; 
Lichtman e Conchello, 2005). A Fig.2.2 mostra o esquema básico de um microscópio de fluorescência.
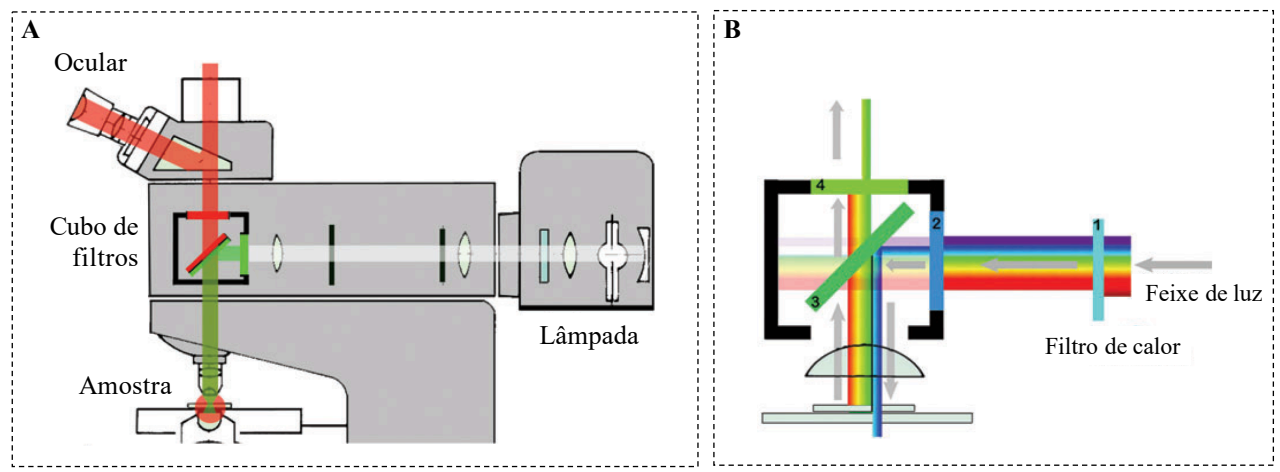

Figura 2.2: Esquema do funcionamento de um microscópio de fluorescência. A: a fonte de luz é uma lâmpada que emite em todo o espectro. A luz passa por um filtro de fluorescência em formato de cubo que, inicialmente, seleciona o comprimento de onda que vai excitar o marcador fluorescente na amostra (exemplificado pela luz verde). O marcador fluorescente absorve e reemite em outro comprimento de onda (exemplificado pela luz vermelha) que atinge a objetiva, e é enviado para os olhos ou para uma câmera. O cubo tem um espelho dicroico e dois filtros de barreira. B: essa imagem exemplifica os detalhes do cubo de filtro. $\mathrm{O}$ filtro de calor (1) bloqueia a passagem de infravermelho, enquanto que os filtros de barreira ( 2 e 4) só permitem a passagem de um comprimento de onda especifico, que nesse exemplo é o azul (2) e o verde (4). Já o espelho dicroico permite que a luz passe em uma determinada faixa de comprimento de onda e seja refletida em outra. Nessa configuração, esse espelho permite que passe apenas o comprimento de onda emitido pelo marcador fluorescente na amostra, enquanto que, o comprimento de onda de excitação seja refletido e não chegue na objetiva (imagem adaptada de (Lichtman e Conchello, 2005)).

A fluorescência é a emissão de luz que ocorre em uma escala de nanosegundos após a absorção da luz que, em geral, é de um comprimento de onda menor. Isso ocorre, pois um pouco de energia é perdida no processo e um feixe de luz com menor comprimento de onda possui mais energia do que um feixe com maior comprimento de onda (Lichtman e Conchello, 2005: Sanderson et al., 2014). A diferença entre o comprimento de onda de excitação e o emitido é conhecido como deslocamento de Stokes. A capacidade de se diferenciar os comprimentos de onda faz com que a microscopia de fluorescência seja tão útil (Lichtman e Conchello, 2005; Alberts et al., 2010).

São os orbitais eletrônicos mais externos da molécula fluorescente que determinam, tanto sua eficiência como marcador fluorescente, quanto os comprimentos de onda de excitação e emissão (Lichtman e Conchello, 2005). Quando o marcador fluorescente, fluoróforo, em seu estado de menor energia é excitado pelo feixe de luz, podem ocorrer 
alterações em seu estado eletrônico, vibracional e rotacional, fazendo com que ele vá para um estado excitado. Para que o fluoróforo volte para seu estado basal, de menor energia, um dos caminhos é a emissão de luz e o relaxamento vibracional (Lichtman e Conchello, 2005).

Uma forma de se explicar como ocorre essa transição molecular de energia foi proposta por Alexander Jablonski, em 1930, e é conhecido como diagrama de Jablonski (Lichtman e Conchello, 2005; Sanderson et al., 2014). Esse diagrama é o mais usado como ponto de partida para discussões sobre absorção e emissão de luz (maiores detalhes sobre o diagrama de Jablonski podem ser visto em (Valeur e Berberan-Santos, 2012; Lakowicz, 1999: Turro, 1991)). A Fig.2.3 representa o esquema básico do diagrama de Jablonski.
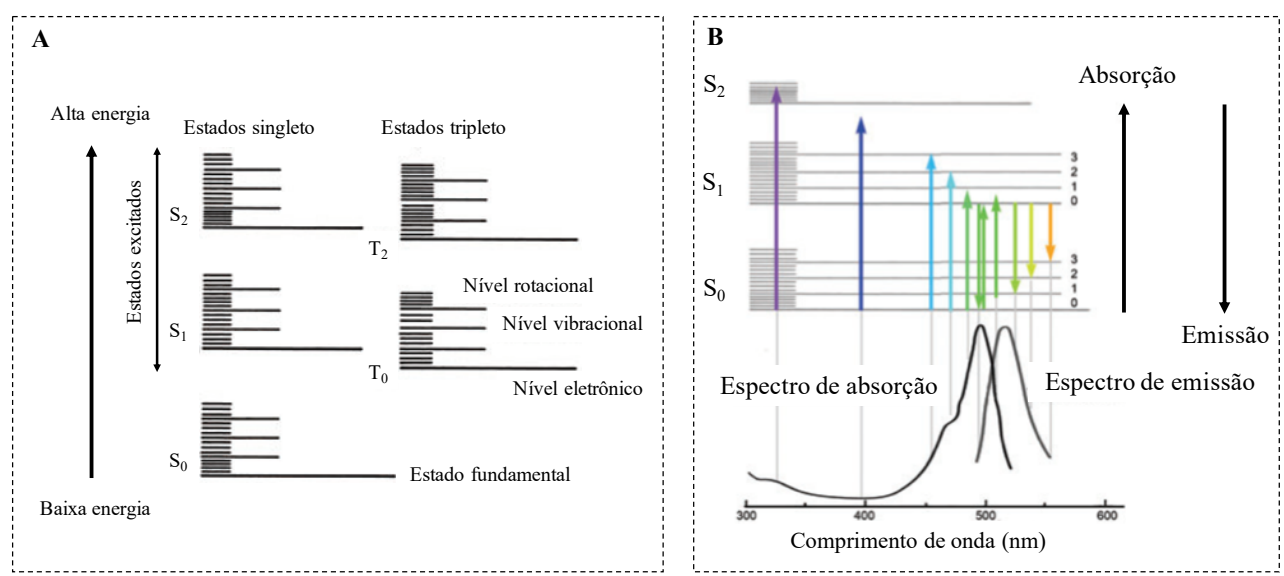

Figura 2.3: Esquema do diagrama de Jablonski para emissão e absorção da luz. A: representação dos estados de energia de uma molécula, conforme o diagrama de Jablonski. B: exemplificação do espectro de emissão e absorção de energia de uma molécula. Os estados de energia estão representados pelas linhas cinzas, onde o espaçamento entre as linhas representa a quantidade de energia necessária para ir de um estado a outro. Abaixo dos estados de energia é exemplificado o espectro de absorção e emissão de um fluoróforo comum. As setas verticais de absorção (seta para cima) e emissão (seta para baixo) estão dispostas nas linhas cinzas horizontais que representam os estados de energia. A coloração das setas representa o comprimento de onda dos fótons. (imagem adaptada de (Lichtman e Conchello, 2005)).

Os estados S são os singletos, com, $\mathrm{S}_{0}$ sendo o estado fundamental, que representa o estado energético da molécula fluorescente que ainda não foi excitada pela luz. Os estados $S_{1}$ e $S_{2}$ são os estados singletos excitados da molécula, onde, um elétron que inicialmente estava em um estado de baixa energia, passa a ocupar um orbital de maior energia. Já o estado T representa o estado tripleto (Lichtman e Conchello, 2005).

Nos estados singleto, o par de elétrons em um orbital, normalmente, estão com spins 
opostos, fazendo com que seu momento angular seja igual a zero. Já no estado tripleto, pode ocorrer que em dois orbitais haja um par de elétrons não ligantes com spins paralelos um ao outro. Átomos ou moléculas com tal configuração podem apresentar momento angular paralelo, perpendicular ou antiparalelo à direção da componente magnética da radiação eletromagnética. Essas três possibilidades de alinhamento correspondem a três possibilidades de energia diferentes, daí o nome de tripleto (Lichtman e Conchello, 2005).

O microscópio de fluorescência foi utilizado em nossos experimentos para a aquisição das imagens dos beads fluorescentes que estavam aderidos ao substrato. Com esse microscópio foi possível visualizar as células, em contraste de fase, para, em seguida, obter as imagens de fluorescência dos beads. Dessa forma, foi possível processar as imagens necessárias para obter as forças de tração que o cardiomiócito realizava no substrato flexível. Na Fig.2.4 é apresentado o microscópio de fluorescência utilizado nos experimentos e algumas das imagens que podem ser visualizadas.

Parte do trabalho aqui desenvolvido está inserido nos propósitos de um projeto Temático em parceria com o nosso grupo de pesquisa, aprovado pela FAPESP (processo número: 2013/17368). Os cardiomiócitos utilizados nos experimentos foram fornecidos pelo InCor, por meio de uma parceria formada com o nosso grupo. Na próxima seção, apresentaremos como os experimentos foram organizados e seus detalhes de execução. 

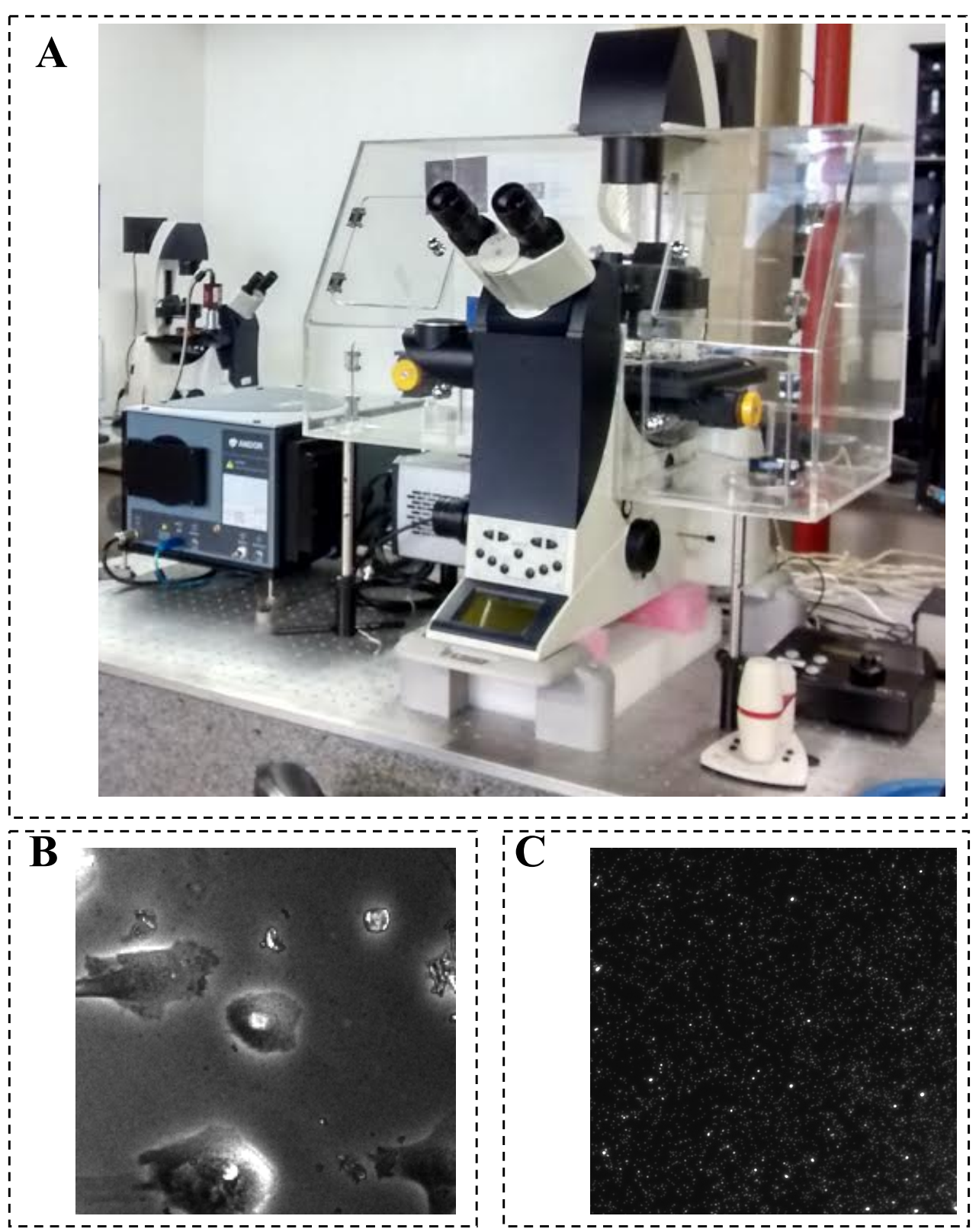

Figura 2.4: A: microscópio de fluorescência (Leica DMI 400B) utilizado nos experimentos. Esse microscópio possui estágio motorizado para controle dos eixos $x$ e $y$, assim como um controlador para se movimentar no eixo $z$. Foi acoplado uma câmera (Andor Neo sCMOS) para aquisição das imagens, um incubador de acrílico, para que fosse possível manter as células a uma temperatura de $37^{\circ} \mathrm{C}$ e com $\mathrm{CO}_{2}$. B: imagem em contraste de fase dos cardiomiócitos. C: imagem em escala de cinza dos beads fluorescentes aderidos no substrato dos cardiomiócitos.

\subsection{Metodologia experimental}

Conforme descrito anteriormente, para a realização dos experimentos foram utilizadas duas linhagens de cardiomiócitos: uma de rato neonato do tipo selvagem (WT), 
considerado como saudável e, outra de rato neonato geneticamente modificado pelo grupo de genética do InCor (KO-CRP3). O nosso grupo de pesquisa possui um ambiente no laboratório especialmente organizado para o cultivo de células. Assim, foi possível armazenar os cardiomiócitos em nitrogênio líquido até o momento da realização dos experimentos.

Inicialmente descongelava-se os cardiomiócitos para que fossem mantidos em cultura até que voltassem a pulsar e os experimentos pudessem ser realizados. O meio de cultura utilizado foi o Dulbecco's Modified Eagle Medium (DMEM), que precisa ser suplementado com $1 \%$ de soro de cavalo (HRS), $5 \%$ de soro fetal de bezerro (NBCS) e $1 \%$ de bromodeoxiuridina (BrdU). Este último foi adicionado para aumentar a pureza dos cardiomiócitos, pois o BrdU previne a proliferação de fibroblastos e outros compostos prejudiciais aos cardiomiócitos. Esse meio de cultura é um suplemento rico em proteínas e estimula o transporte de glicose, fosfato e aminoácidos, além de aumentar a permeabilidade das membranas (Carvalho e Recco-pimentel, 2007).

A cultura de células, em geral, precisa ser realizada em condições de temperatura e umidade adequadas, ou seja, as células devem ser mantidas em uma incubadora a $37^{\circ} \mathrm{C}$ e a um volume controlado de $5 \%$ de $\mathrm{CO}_{2}$. A Fig. 2.5 mostra os equipamentos da sala de

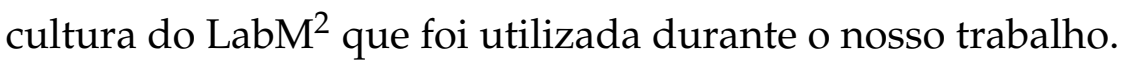
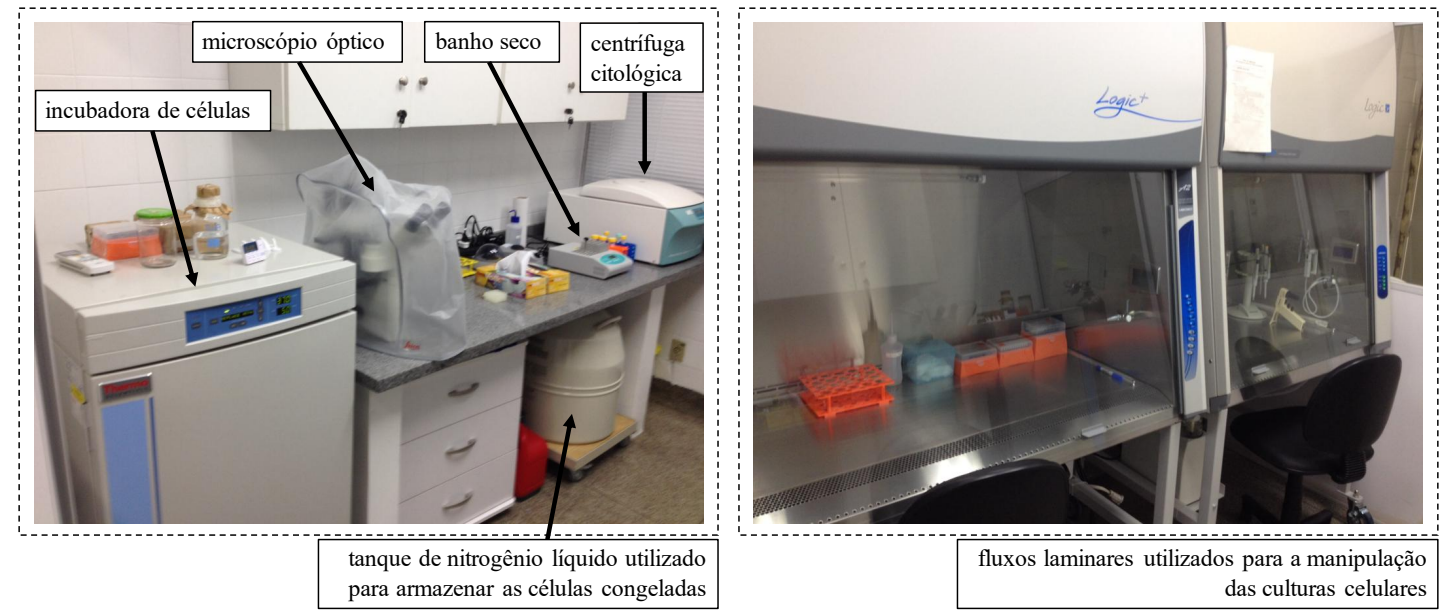

Figura 2.5: A figura mostra os principais equipamentos presentes na sala de cultura celular do grupo de pesquisa do $\mathrm{LabM}^{2}$. Todas as manipulações com as células foram realizadas nos fluxos laminares, à direita.

Após o cultivo dos cardiomiócitos, é preciso que eles sejam depositados em um substrato, formado por um gel de poliacrilamida sobreposto a uma placa de Petri com 
fundo de vidro. Os detalhes do protocolo para preparo do gel de poliacrilamida podem ser lidos no Apêndice (A). Após o preparo do gel e sua ativação para que as células possam ser depositadas sobre ele, as células aderidas eram armazenadas na incubadora por cerca de 48 horas antes da realização dos experimentos.

Cumprida essa etapa, a placa de Petri com os cardiomiócitos aderidos ao gel era levada ao microscópio de fluorescência. Após identificar um cardiomiócito isolado, pelo contraste de fase do microscópio, realizava-se uma filmagem da movimentação dos beads fluorescentes sobre o qual o cardiomiócito estava depositado. O tempo de filmagem foi de 20 segundos a uma taxa de aquisição de $145 \mathrm{fps}$ (imagens por segundo). Esse processo era realizado com, aproximadamente, dez cardiomiócitos isolados, para as duas linhagens, WT e KO-CRP3.

Após essas primeiras medidas com os cardiomiócitos em seus estados basais, era realizada uma nova série de aquisição com os cardiomiócitos estimulados pela ação de um fármaco, o isoproterenol. Esse estimulante pode ser usado como tratamento de arritmias e um de seus efeitos é o aumento da pressão arterial. O isoproterenol induz um transtorno de ritmo cardíaco (taquicardia) e uma hipertrofia dos cardiomiócitos, agravando a morte celular e levando a problemas cardíacos, se exposto por um tempo prolongado (Zhuo et al., 2013: Zou et al., 1999).

Por fim, a ligação das células com o substrato era quebrada com a aplicação da tripsina e os cardiomiócitos eram todos retirados do substrato. Em seguida, era adquirida uma imagem dos beads referente à posição de cada cardiomiócito analisado, sem aplicação das forças de tração. Essa imagem é utilizada como referência para se calcular o campo de deslocamento dos beads fluorescentes durante a pulsação dos cardiomiócitos, conforme descrito na seção (2.1).

Dessa forma, em cada rodada de experimento, obteve-se quatro grupos de análise: os cardiomiócitos WT e KO-CRP3 em seus estados basais, e os mesmos estimulados pelo isoproterenol, que foram chamados de WT-ISO e KO-CRP3-ISO. Durante os 20 segundos de filmagem, a uma taxa de aquisição de 145 fps, foram obtidas 2.900 imagens da movimentação dos beads durante o ciclo de contração dos cardiomiócitos. Cada imagem obtida é interpretada como uma matriz $i \times j$ de tamanho $512 \times 512$ onde, cada elemento da matriz corresponde a um pixel da imagem. Utilizando uma lente de aumento de $40 \times$ no microscópio, a resolução espacial é de $0.16 \mu \mathrm{m}$ por pixel. Como resultado, obtém-se 
um conjunto de $n$ matrizes, cada uma com as componentes das forças de tração, $F_{x}$ e $F_{y}$, por elemento (pixel), conforme exemplificado na Fig.2.6.
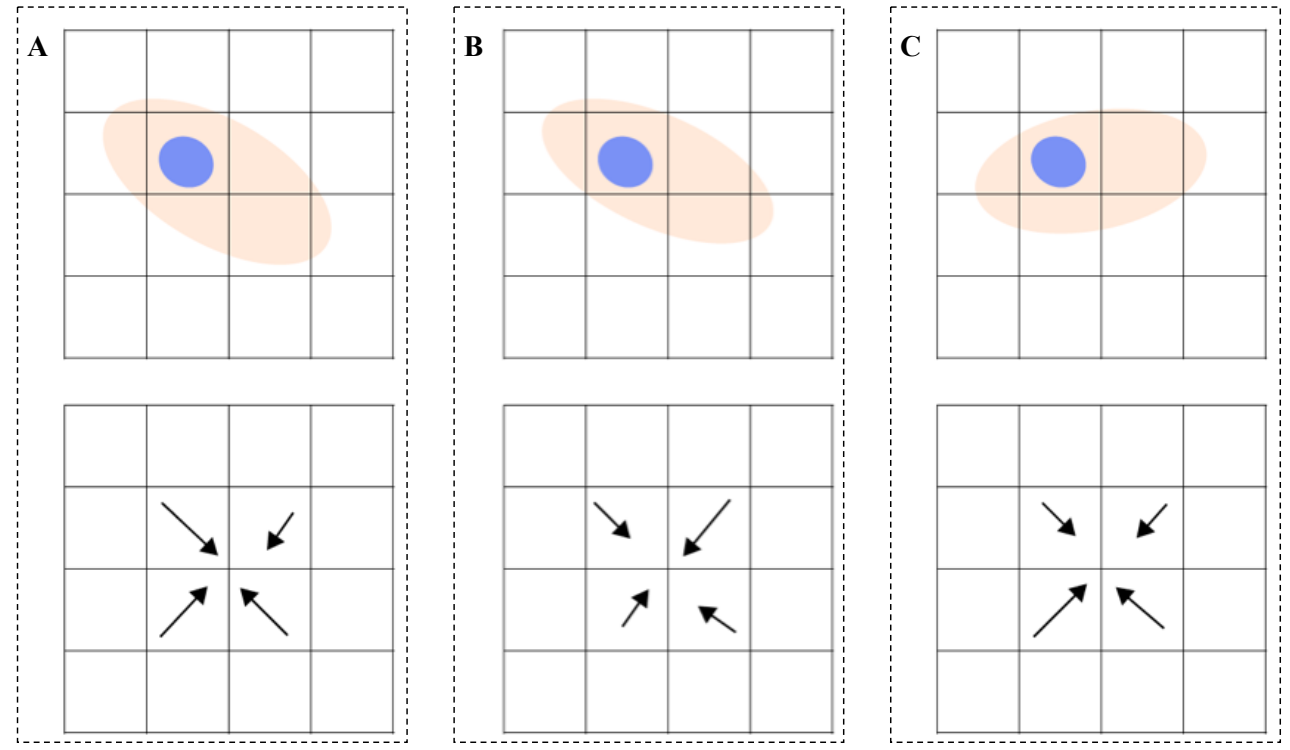

Figura 2.6: Esquema da representação das imagens obtidas pelo TFM na representação matricial. As imagens A, B e $\mathbf{C}$ representam uma sequencia de três imagens da mesma célula com suas respectivas matrizes de força de tração. As setas ilustram as forças de trações tangenciais, $F_{x}$ e $F_{y}$, aplicadas pela célula no substrato flexível.

As forças de trações tangenciais de cada elemento da matriz formam um mapa de tração para cada imagem adquirida. Com isso é possível obter a força resultante, por elemento de matriz. No geral, o que se obtém com esse mapa de tração é a chamada força total, $F_{\mathrm{T}}$, que é a soma da força resultante de cada elemento da matriz (maiores detalhes serão apresentados no capítulo seguinte). Assim, para cada imagem adquirida, tem-se um valor de $F_{\mathrm{T}}$ e, com isso é possível ajustar um gráfico desse valor em função do tempo de aquisição. A Fig. 2.7 ilustra uma imagem do cardiomiócito da linhagem KO-CRP3 para ilustrar o mapa das forças de tração médias e o comportamento típico da $F_{\mathrm{T}}$. 

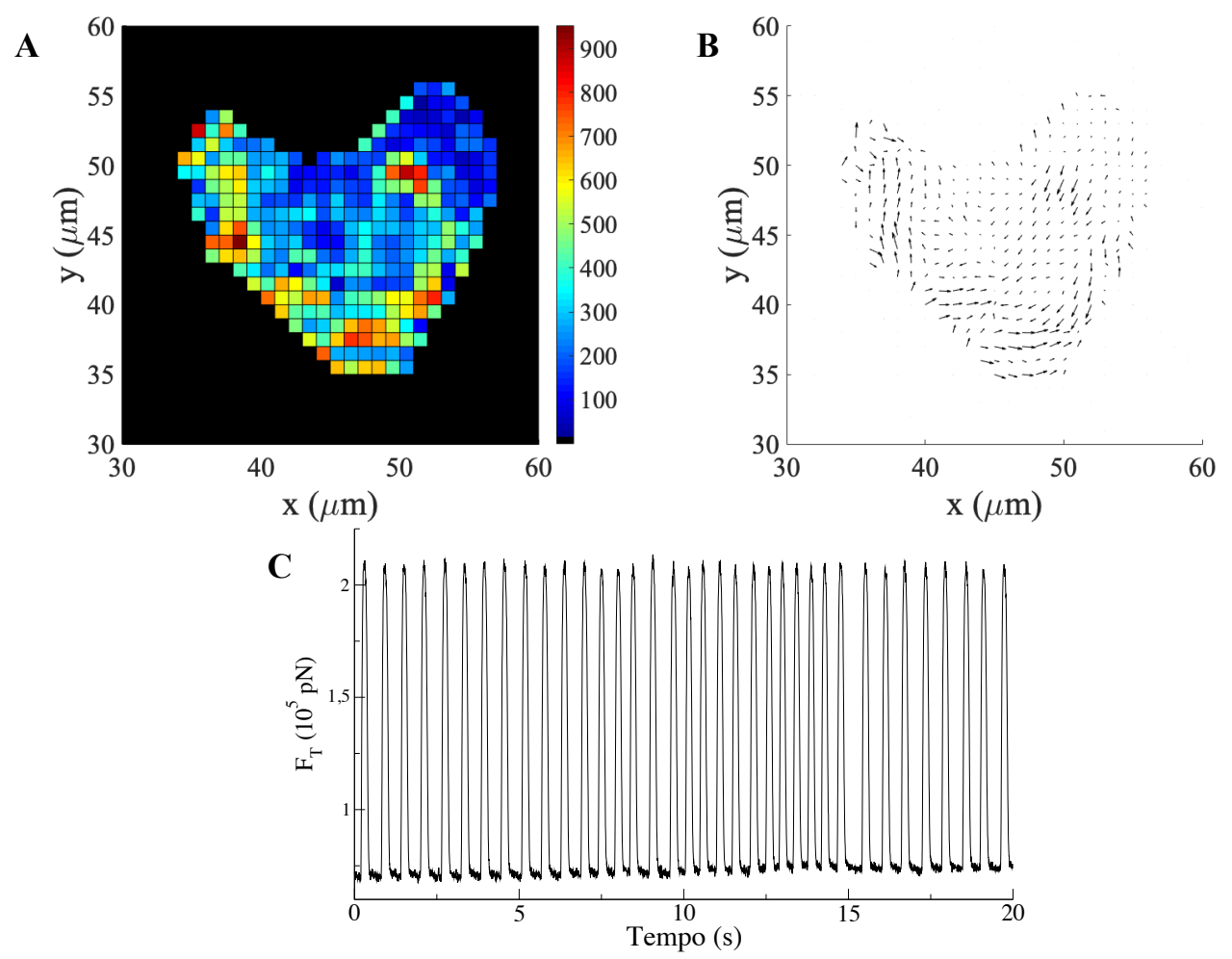

Figura 2.7: A: Tem-se o mapa da intensidade das forças de tração média onde, os valores de intensidade aumentam do azul para o vermelho. B: Tem-se os vetores de força de tração média que estavam atuando no cardiomiócito da linhagem KO-CRP3 durante o ciclo de contração. C: Representam o comportamento da $F_{\mathrm{T}}$ durante o ciclo de contração do cardiomiócito analisado.

O comportamento da $F_{\mathrm{T}}$ na Fig.2.7(C) é oscilatório no tempo, aumentando durante a contração do cardiomiócito e diminuindo durante o relaxamento. No entanto, analisando apenas a $F_{\mathrm{T}}$, perde-se informações sobre a orientação do mapa de forças (Fig.2.7.(B)) durante o ciclo de contração e em pontos mais específicos, como, por exemplo, os de máximo e mínimo da $F_{\mathrm{T}}$. Poder olhar com mais detalhes o mapa de forças de tração e analisar o alinhamento e orientação dessas forças é um dos propósitos principais desse trabalho. No capítulo seguinte será apresentada toda a metodologia desenvolvida para se analisar com mais detalhes a dinâmica das forças de tração durante o ciclo de contração dos cardiomiócitos e, em seguida, como os dados gerados podem fornecer um melhor entendimento dessa dinâmica.

Para que fosse possível uma boa análise dos resultados, foi preciso organizar o protocolo experimental de forma a se obter um número suficiente de cardiomiócitos processados para as comparações dos parâmetros entre as duas linhagens de células. 
Dessa forma, foram realizadas cinco rodadas de experimentos, onde em cada uma, procurou-se processar em torno de dez cardiomiócitos isolados. Ao todo foi obtido um conjunto de 31 cardiomiócitos da linhagem WT e 27 cardiomiócitos da linhagem KOCRP3. Essa quantidade de cardiomiócitos é a que foi possível de se obter no estado basal e estimulada com o isoproterenol em ambas as linhagens, ou seja de forma pareada. Dessa forma foi possível comparar a dinâmica de forças de tração do mesmo cardiomiócito no estado basal e com isoproterenol.

Assim, foram desenvolvidas ferramentas computacionais capazes de interpretar esses dados e gerar resultados referentes às propriedades mecânicas e estruturais das forças de tração dos cardiomiócitos. Os dados obtidos foram processados em uma plataforma de análise desenvolvida em ambiente MATLAB R2015a 64-bit em um computador (Macintosh) Intel Core i7 de $2.3 \mathrm{GHz}$ com quatro núcleos e 4GB de RAM. A Fig.2.8, a seguir, apresenta o esquema geral da metodologia utilizada em cada rodada de experimento e os principais parâmetros analisados. O próximo capítulo detalha o desenvolvimento das ferramentas computacionais de análise dos dados e os principais resultados obtidos.

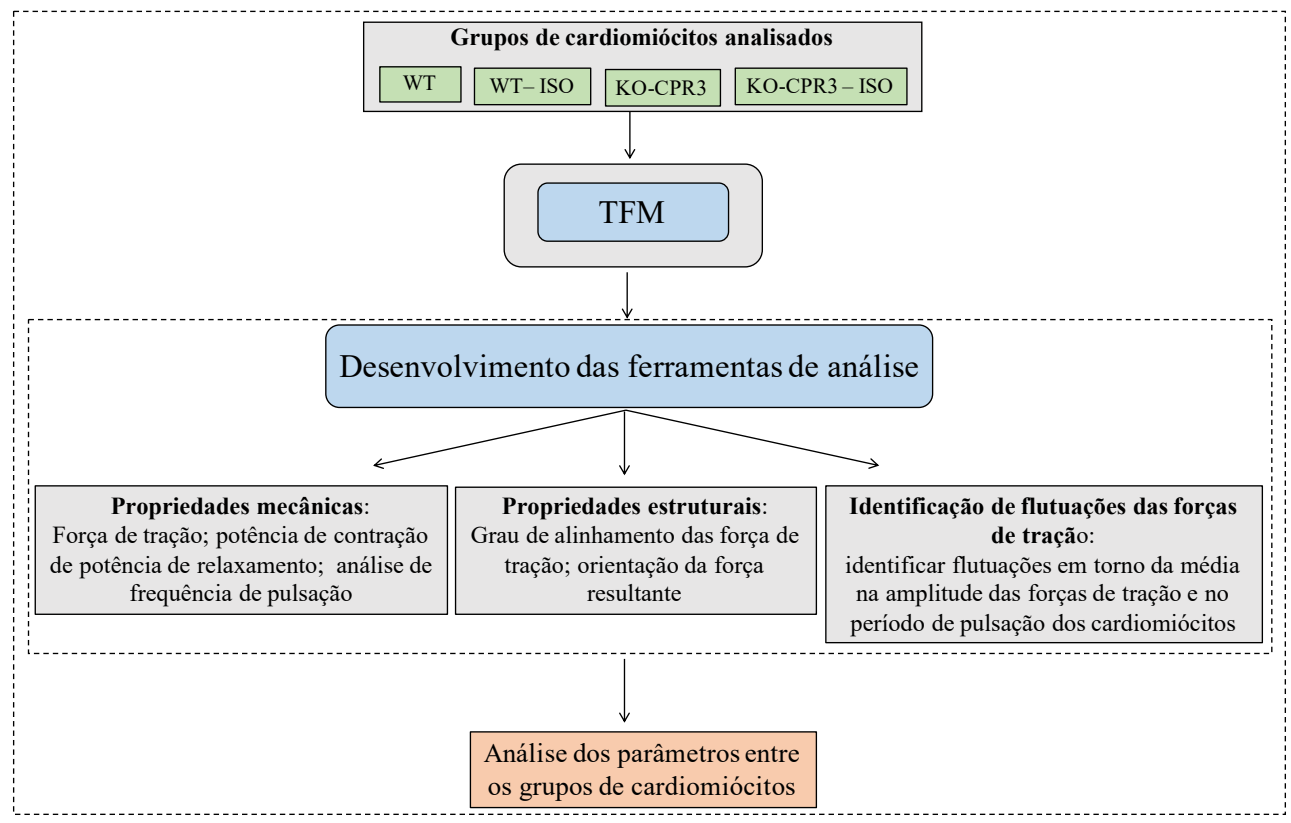

Figura 2.8: Esquema da metodologia experimental. Na parte superior é apresentado os grupos de cardiomiócitos analisados em cada rodada de experimentos. Logo abaixo é apresentado a técnica experimental utilizada, o TFM. Por fim, é mostrado os principais parâmetros analisados, que serão utilizados nas análises estatísticas e comparação entre os grupos. 


\subsection{Objetivos}

O objetivo geral dessa pesquisa é desenvolver metodologias computacionais capazes de obter novos parâmetros que possam colaborar para o melhor entendimento da dinâmica de forças de cardiomiócitos durante o ciclo de contração. Mais especificamente, pretende-se:

\section{Obtenção do campo de forças de tração dos cardiomiócitos}

Utilizar a técnica de TFM para obtenção das forças de tração de duas linhagens de cardiomiócitos, WT e KO-CRP3, em estados basais e estimuladas por um fármaco, o isoproterenol.

\section{Desenvolvimento de metodologias de análise de propriedades mecânicas dos} cardiomiócitos

Desenvolver metodologias de análise computacional para obtenção de parâmetros relacionados à dinâmica das forças de tração dos cardiomiócitos. Mais especificamente, parâmetros relacionados a frequência de pulsação dos cardiomiócitos, alinhamento das forças de tração durante os ciclos de contração e a potência realizada pelo cardiomiócito durante a contração e o relaxamento.

\section{Aplicação das ferramentas de análise nas amostras de cardiomiócitos}

Aplicar as metodologias computacionais de análise desenvolvidas nos dados referentes às forças de tração, obtidas pela técnica de TFM, para as duas linhagens de cardiomiócitos utilizadas. A partir das análises geradas, caracterizar o comportamento mecânico tempo-dependente das células e como este se modifica sob a influência do isoproterenol em ambas as linhagens. 


\section{Capítulo 3}

\section{Desenvolvimento das ferramentas de análise}

No capítulo anterior foi visto que a técnica de TFM é capaz de medir o campo de força de tração exercida por uma célula sobre um substrato flexível onde se encontra aderida. A partir desse campo de tração, é possível medir o momento contrátil líquido, energia de tensão, força cumulativa máxima, entre outros. Nos experimentos utilizando cardiomiócitos, os parâmetros que geralmente são calculados referem-se à frequência e período de batimento e amplitude entre os pontos de força máxima e mínima (Jensen et al., 2018). Mas, esses parâmetro não se mostraram suficientes para caracterizar a dinâmica dos cardiomiócitos, dada a variabilidade biológica dessas células.

Devido a isso, desenvolvemos ferramentas computacionais de análise capazes de identificar parâmetros relativos ao comportamento mecânico e estrutural de cardiomiócitos, a partir das matrizes de força de tração obtidas pelo TFM. O fluxograma da Fig.3.1ilustra as etapas experimentais desenvolvidas até o desenvolvimento dessas ferramentas. 
(1) Preparo do Gel: Realização de todo o procedimento experimental para montagem do gel de poliacrilamida.
(2) Adesão dos cardiomiócitos: Cultivo dos cardiomiócitos até o seu depósito sobre o gel para ocorrerem as adesões focais. Em seguida os cardiomiócitos são levados para a incubadora por 48 horas.
(5) Desenvolvimento das ferramentas de análise
(3) Experimento do TFM:

Realização da aquisição das imagens dos beads fluorescentes pelo microscópio de fluorescência.

(4) Obtenção dos campos de força de tração:

Processamento das imagens adquiridas com o TFM para obtenção das matrizes de forças de tração nos eixos $x$ e $y$.

Figura 3.1: Fluxograma das etapas envolvidas para a realização do TFM até a obtenção dos campos de força de tração. As ferramentas de análise aqui desenvolvidas encontram-se na etapa 5 .

Essa metodologia foi aplicada nas duas linhagens de cardiomiócitos, WT e KO-CRP3, antes e depois da aplicação do isoproterenol. Nesse capítulo, apresentaremos a metodologia de análise computacional desenvolvida, assim como os parâmetros mecânicos e estruturais obtidos, e como eles se comportam entre as linhagens de cardiomiócitos analisadas.

\subsection{Forças de tração}

Pela técnica de TFM, após a análise dos deslocamentos dos beads aderidos ao substrato de gel, obtém-se duas matrizes, de dimensões $80 \times 80$, para cada imagem adquirida durante a filmagem, referente a etapa 4 da Fig. 3.1. Essa etapa é realizada por um software fechado obtido em colaboração com os desenvolvedores da técnica de TFM, onde, as imagens dos beads são processadas para se obter as matrizes de forças de tração. Em uma das matrizes, cada elemento representa um componente da força de tração no eixo $x, F_{x}$, e na outra, cada componente da força de tração no eixo y, $F_{y}$. A primeira análise feita, a partir dessas matrizes, foi calcular o módulo da força total por imagem $\left(F_{\mathrm{T}}\right)$. Para isso, calculou-se o módulo da resultante para cada elemento da matriz, da seguinte forma:

$$
R(i, j)=\sqrt{F_{x}(i, j)^{2}+F_{y}(i, j)^{2}},
$$

cuja orientação é dada por:

$$
\theta_{\mathrm{R}}(i, j)=\arctan \left(\frac{F_{y}(i, j)}{F_{x}(i, j)}\right)
$$


Em seguida, calculou-se a $F_{\mathrm{T}}$ em cada imagem, pela somatório das forças de tração de cada elemento da matriz:

$$
F_{\mathrm{T}}=\sum_{i, j} R(i, j)
$$

A $F_{\mathrm{T}}$ ao longo do tempo de filmagem pode ser vista na Fig. 3.2. Os asteriscos destacados em vermelho representam os pontos de máximo e mínimo da $F_{\mathrm{T}}$.

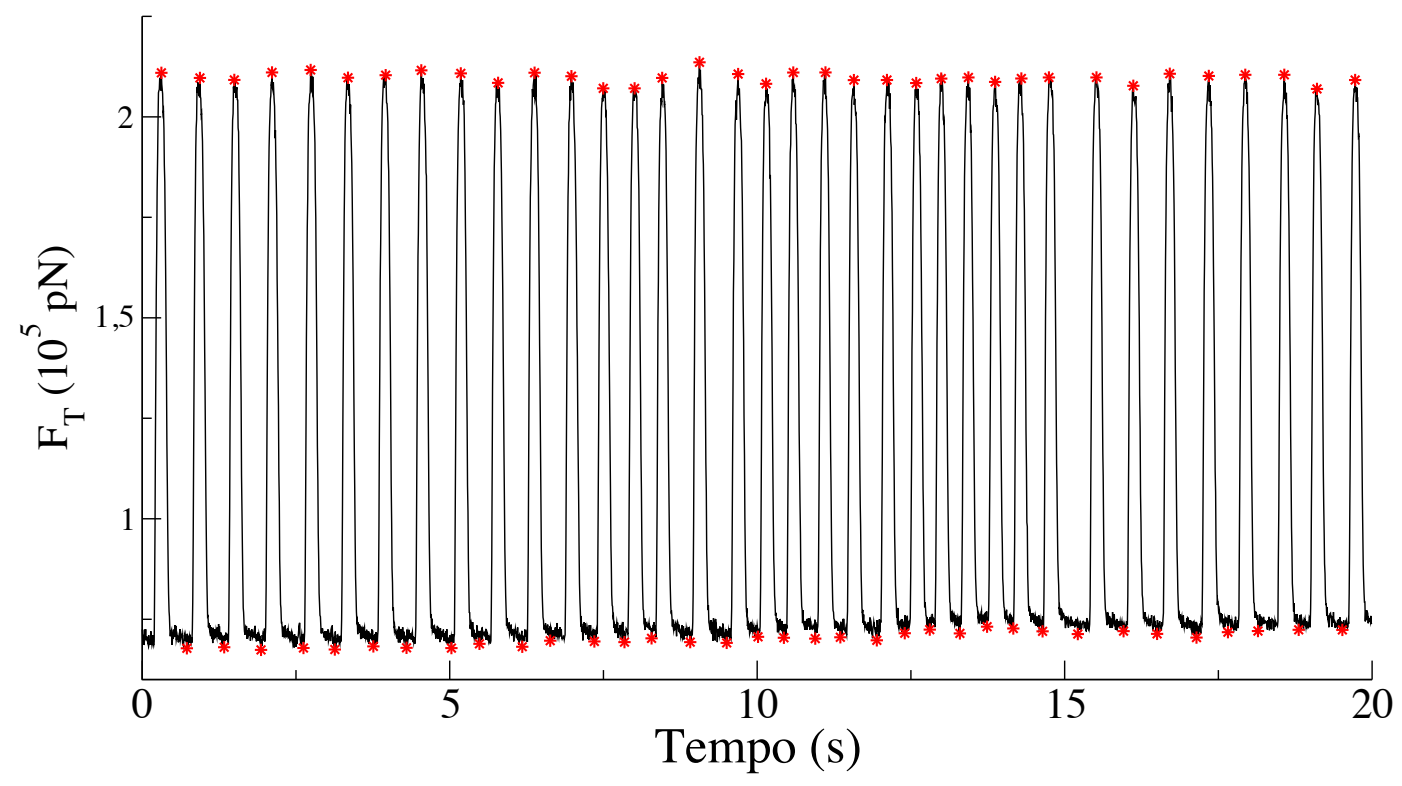

Figura 3.2: Comportamento da $F_{\mathrm{T}}$ ao longo do tempo. Essa medida foi realizada em um cardiomiócito da linhagem KO-CRP3, que representa o comportamento padrão para as células analisadas. A $F_{\mathrm{T}}$ apresenta um comportamento senoidal, com pontos de máximo e mínimo de força bem definidos, indicados pelos asteriscos em vermelho.

A Fig. 3.2 ilustra o comportamento típico da $F_{\mathrm{T}}$ durante o ciclo de contração dos cardiomiócitos analisados. A $F_{\mathrm{T}}$ é o parâmetro de referência para as diversas outras análises que podem ser desenvolvidas para se caracterizar a dinâmica de forças dos cardiomiócitos, conforme será apresentado ao longo do capítulo.

A fim de refinar a análise das forças de tração, resolveu-se verificar o comportamento do que foi chamado de força resultante $F_{\mathrm{R}}$. Esse parâmetro representa a força resultante por imagem adquirida. Para isso, com as matrizes das forças $F_{x}$ e $F_{y}$ adquiridas durante a filmagem, calculou-se a força resultante em x e y pela soma da força em cada elemento da matriz, da seguinte forma: 
Força resultante em $\mathrm{x}$ :

$$
F_{\mathrm{R} x}=\sum_{i, j} F_{x}(i, j)
$$

Força resultante em y:

$$
F_{\mathrm{R} y}=\sum_{i, j} F_{y}(i, j)
$$

por fim, para a força resultante, temos:

$$
F_{\mathrm{R}}=\sqrt{F_{R x}^{2}+F_{R y}^{2}}
$$

O comportamento da $F_{\mathrm{R}}$ ao longo do tempo, para uma célula de cardiomiócito da linhagem KO-CRP3, pode ser visto na Fig. 3.3.

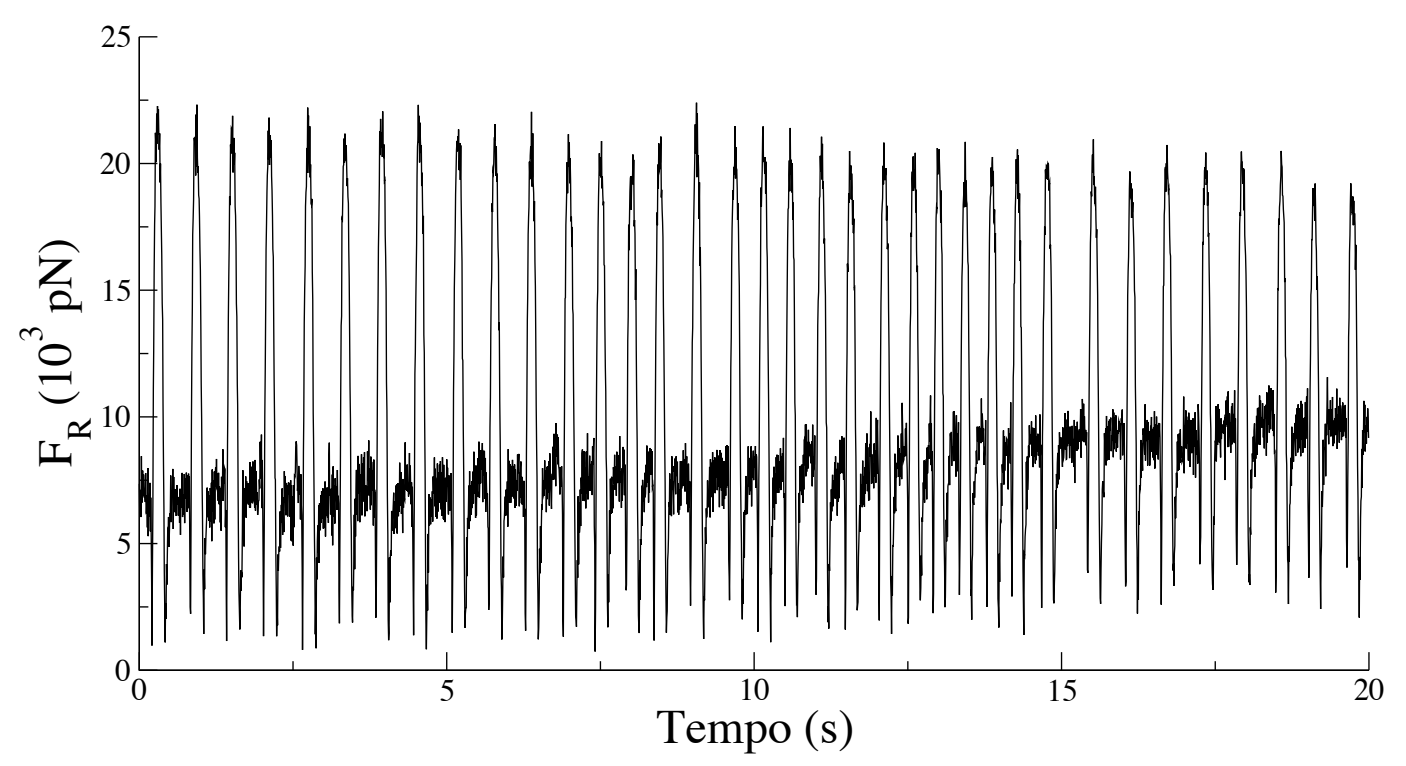

Figura 3.3: Comportamento da $F_{\mathrm{R}}$ ao longo do tempo. A $F_{\mathrm{R}}$ apresenta um comportamento diferente da $F_{\mathrm{T}}$ e mostra que existe um desequilíbrio entre as componentes da forças durante o ciclo de contração dos cardiomiócito.

Pelo gráfico da Fig. 3.3, pode-se perceber que a $F_{\mathrm{R}}$ apresenta um comportamento oscilatório ao longo do ciclo de contração. Isso significa que durante a pulsação dos cardiomiócitos, estes realizam mais forças em uma região do gel do que outra. Esse dado é relevante para a análise da dinâmica de forças dos cardiomiócitos possibilitando verificar a orientação da $F_{\mathrm{R}}$, por: 


$$
\theta_{F_{\mathrm{R}}}=\arctan \left(\frac{F_{R y}(i, j)}{F_{R x}(i, j)}\right)
$$

Dessa forma, obteve-se grau de alinhamento das forças de tração, e da orientação da $F_{R}$, conforme será mostrado a seguir. Tanto essa metodologia quanto as demais que serão apresentadas, utilizou-se uma célula de referência para demonstrar o método.

\subsection{Quantificação de parâmetros estruturais de alinhamento das forças de tração}

A primeira análise estrutural realizada foi a medida do alinhamento das forças de tração dos cardiomiócitos. Essa metodologia foi desenvolvida durante o projeto de mestrado do presente autor deste trabalho, aprimorada durante o atual projeto de doutorado e agora, adaptada para análise do alinhamento das forças de tração dos cardiomiócitos ao longo do tempo. Os resultados do primeiro trabalho desenvolvido com essa metodologia podem ser vistos no Anexo (B) (Dorta et al., 2018).

O primeiro passo da análise é ajustar um histograma de $\theta_{\mathrm{R}}(\mathrm{Eq}$.3.2) e identificar a orientação preferencial da distribuição, $\Pi(\theta)$. Em seguida, centraliza-se essa orientação preferencial em $\theta=0$, e redistribui-se os ângulos em torno dessa orientação. Com isso, para cada imagem, obtém-se um histograma de $\theta_{R}$. Dessa forma é possível estimar como os ângulos estão distribuídos em torno da orientação preferencial, pelo cálculo da Curtose da distribuição (Kemeny e Clyne, 2011: Yoshigi et al., 2003). A figura abaixo ilustra como é realizado o deslocamento do ângulo preferencial no histograma de $\theta_{\mathrm{R}}$.

Dessa forma, calculou-se a Curtose da distribuição, Curtose $[\Pi(\theta)]$, tendo em vista que esse é um parâmetro importante para se descrever a forma de uma distribuição (Kemeny e Clyne, 2011; Yoshigi et al., 2003). Em suma, a Curtose fornece uma medida da dispersão dos dados com relação ao pico da distribuição, $\Pi(\theta)$, e é dada por:

$$
\text { Curtose }[\Pi(\theta)]=\frac{1}{L^{2}} \frac{\left[\sum_{i, j}\left(\theta_{\mathrm{R}}-\bar{\theta}\right)^{4}\right]}{\left(\sigma^{2}\right)^{2}},
$$

sendo, $L$ o tamanho da matriz, $\bar{\theta}$ a média da amostra e $\sigma$ o desvio padrão de $\theta_{\mathrm{R}}$.

Uma distribuição Normal, possui um valor de Curtose $[\Pi(\theta)]=3$. Para distribuições dispersas, ou mais achatadas que a Normal, Curtose $[\Pi(\theta)]<3$, indicando uma maior 
A

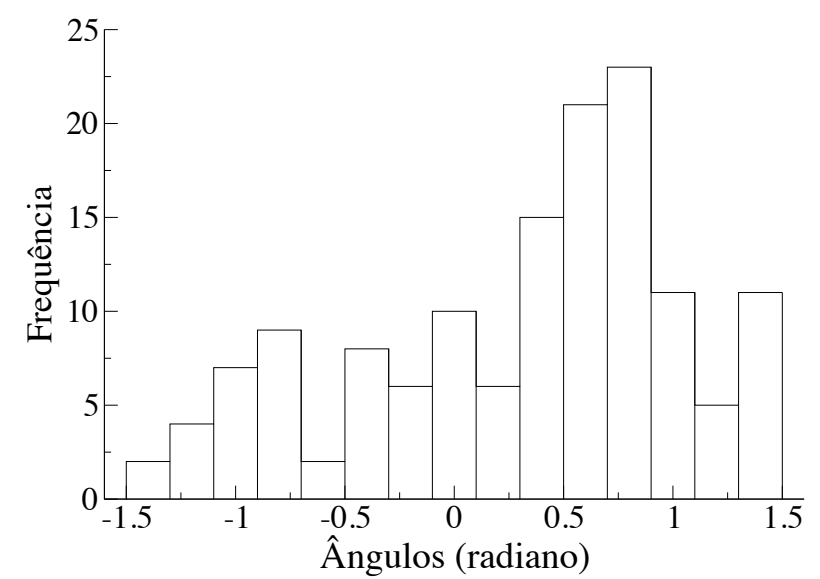

B

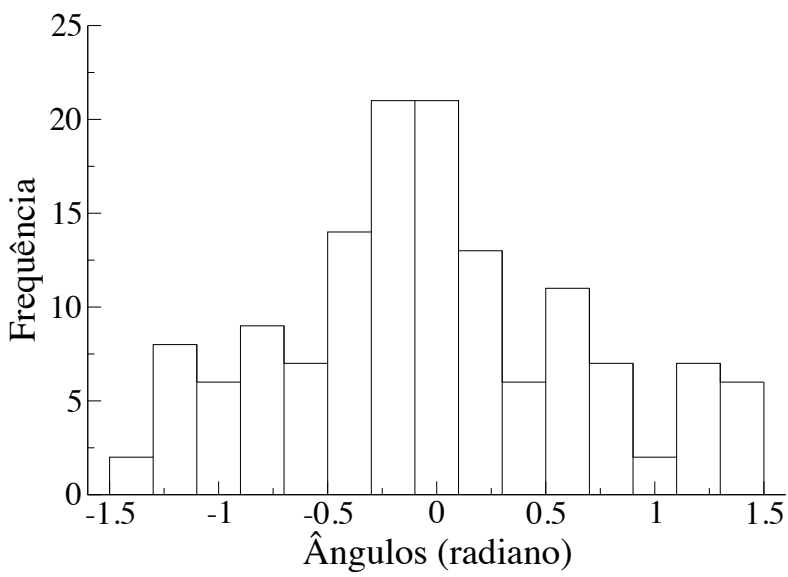

Figura 3.4: A: Histograma de $\theta_{R}$. B: Histograma de $\theta_{R}$ com a orientação preferencial centrada em $\theta=0$. O alinhamento das forças de tração foram obtidas pelo histograma da Fig. B.

dispersão dos dados com relação ao pico da distribuição. Para distribuições mais afuniladas em torno do pico, Curtose $[\Pi(\theta)]>3$, indicando uma maior concentração dos dados em um ponto de máximo da distribuição.

Dessa forma, associou-se um valor de Curtose para cada imagem adquirida durante a filmagem, onde, valores de Curtose maiores que 3 foram considerados como alto grau de alinhamento, enquanto que valores menores que 3 foram consideradas como baixo grau de alinhamento. Por fim, ajustou-se um gráfico da Curtose em função do tempo de filmagem para verificar o comportamento do grau de alinhamento durante o ciclo de contração do cardiomiócito, conforme Fig. 3.5. 


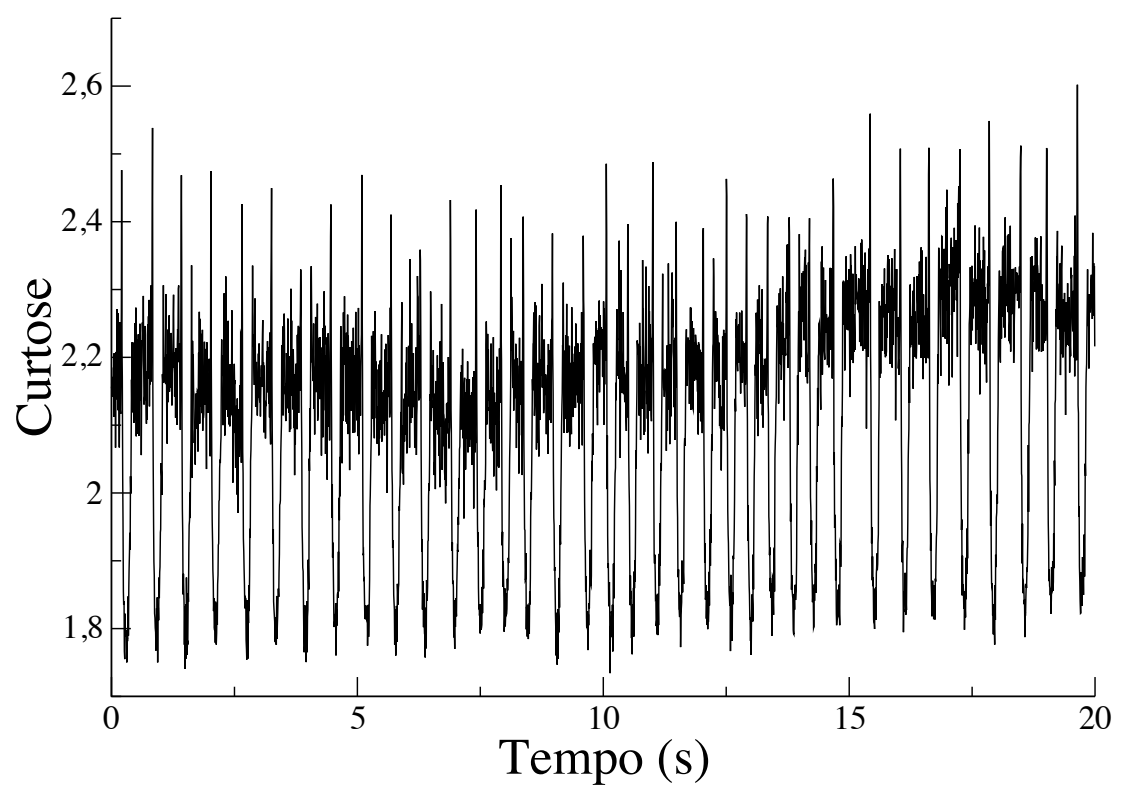

Figura 3.5: Nesse gráfico, mostra-se o comportamento da Curtose durante a pulsação do cardiomiócito para uma amostra celular da linhagem KO-CRP3. Valores acima de 3 são considerados como alto grau de alinhamento.

Análise semelhante foi realizada para a força resultante $F_{\mathrm{R}}$. Uma vez que, durante a pulsação do cardiomiócito, existe uma força resultante diferente de zero, pode-se obter a orientação dessa força, pela Eq. 3.7. Assim foi possível obter a orientação da $F_{\mathrm{R}}$ ao longo da pulsação do cardiomiócito analisado. A Fig. 3.6 representa esse comportamento para um cardiomiócito da linhagem KO-CRP3. Na curva da Fig. 3.6. vê-se que a orientação da $F_{\mathrm{R}}$ apresenta um comportamento oscilatório ao longo do tempo. 


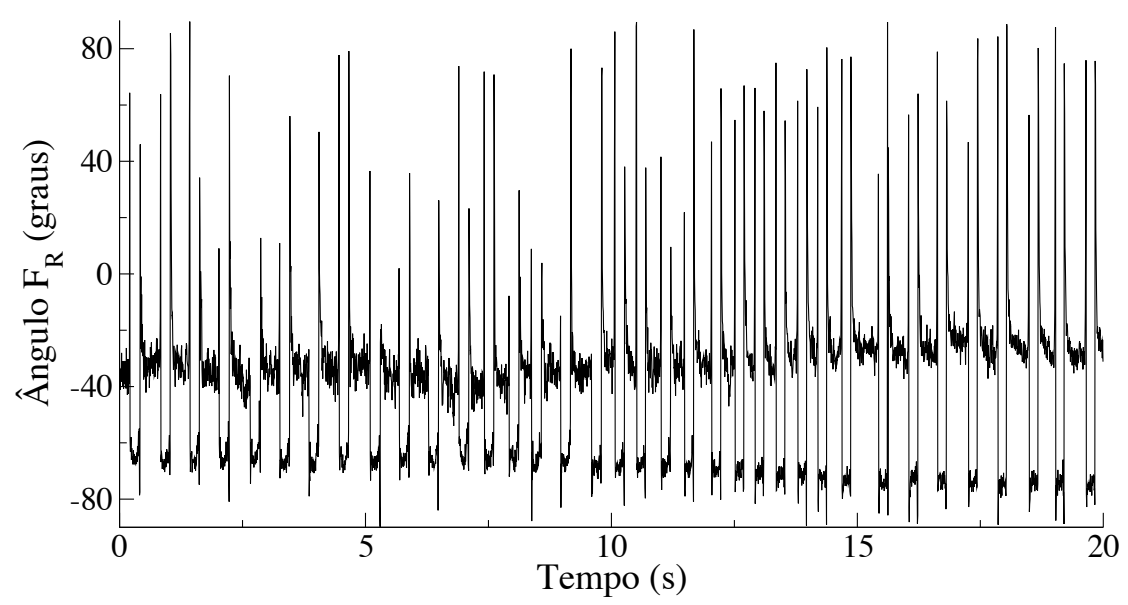

Figura 3.6: Nesse gráfico, mostra-se o comportamento da orientação da força resultante durante o ciclo de contração para um cardiomiócito da linhagem KO-CRP3.

Dessa forma é possível gerar um histograma do ângulo da $F_{\mathrm{R}}$, mostrado na Fig.3.6. para verificar se durante o ciclo de contração a $F_{R}$ se desloca com uma orientação preferencial. A Fig. 3.7 apresenta o histograma dos ângulos referentes a Fig. 3.6.

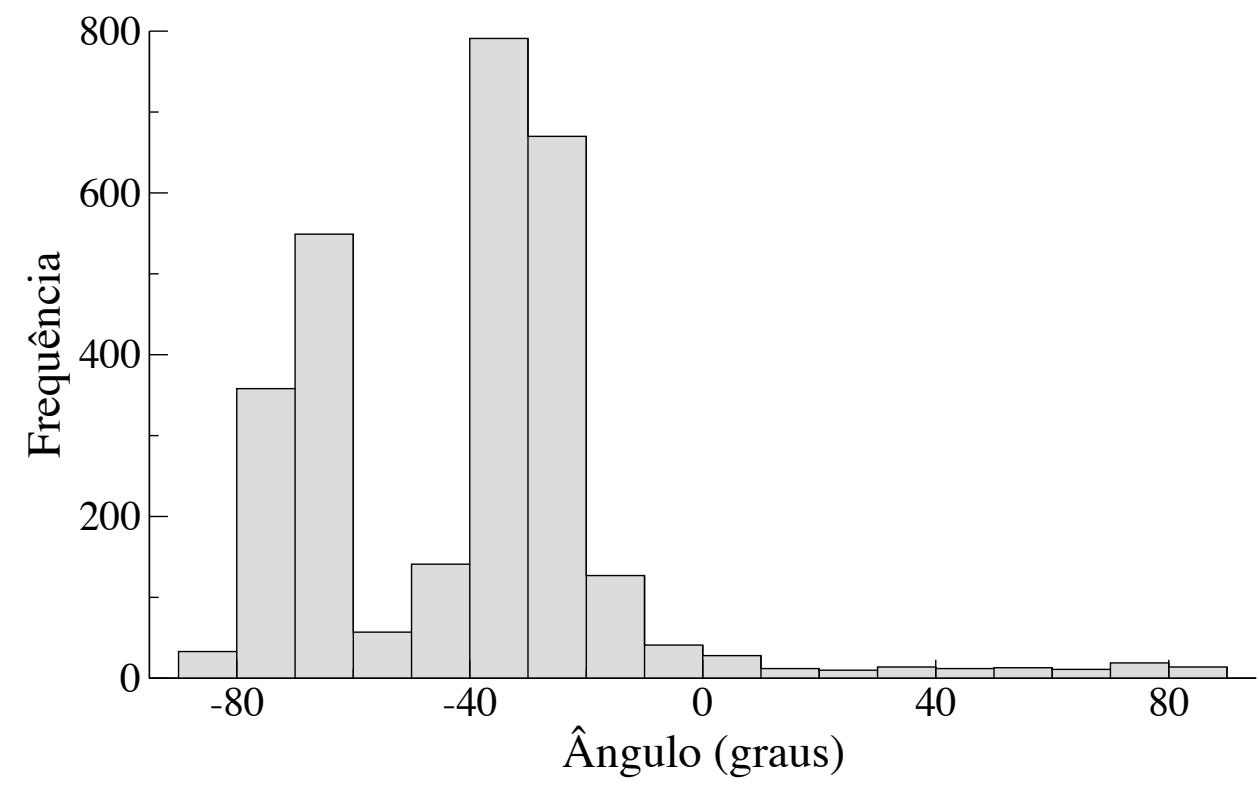

Figura 3.7: Nesse gráfico, mostra-se o histograma dos ângulos da $F_{R}$ durante a pulsação do cardiomiócito para uma amostra celular da linhagem KO-CRP3. Esse histograma apresenta um pico próximo de $-30^{\circ}$ e outro próximo de $-70^{\circ}$. 
Pelo histograma da Fig. 3.7podemos verificar que existem dois picos de orientação preferencial da $F_{R}$ que fica em torno de $-30^{\circ} \mathrm{e}-70^{\circ}$. Dessa forma, podemos verificar como esse parâmetro se comporta entre os cardiomiócitos das linhagens analisadas. Diferente da análise da Curtose, aqui pretende-se verificar se existe algum tipo de orientação preferencial da $F_{\mathrm{R}}$ durante o ciclo de contração do cardiomiócito.

A fim de comparar o comportamento dos parâmetros de $F_{\mathrm{T}}, F_{\mathrm{R}}$, Curtose e $\theta_{F_{\mathrm{R}}}$, ajustouse um gráfico desses parâmetros durante um pequeno intervalo de tempo (2,5 segundos), conforme Fig. 3.8. Com esse gráfico é possível perceber como tais parâmetros se comportam durante o ciclo de contração para um determinado cardiomiócito da linhagem KO-CRP3, que foi utilizado como exemplo para demonstrar a metodologia. Pode-se observar que os parâmetros de $F_{\mathrm{T}}, F_{\mathrm{R}}$ se comportam de forma simétrica, enquanto que a Curtose e o ângulo do $F_{R}$ tendem a diminuir, enquanto que os demais parâmetros aumentam seu valor.

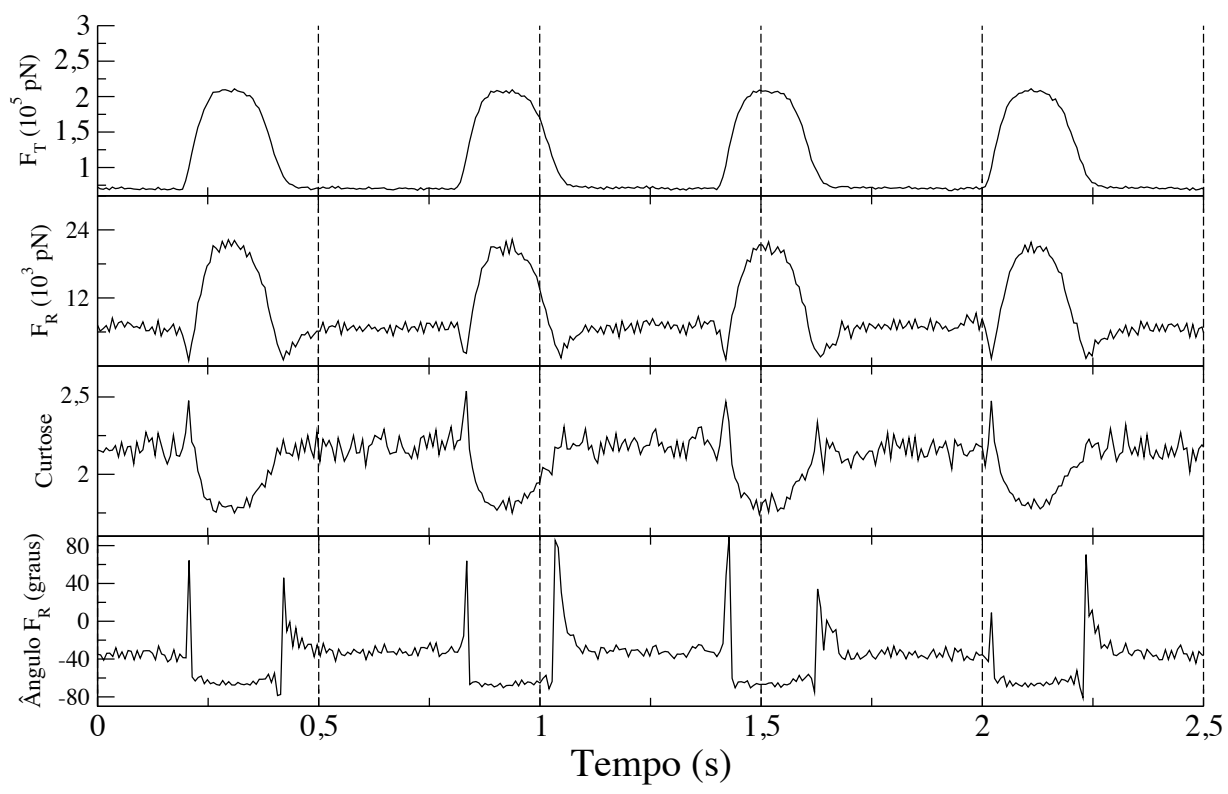

Figura 3.8: Nesse gráfico, mostram-se os comportamentos da $F_{\mathrm{T}}, F_{\mathrm{R}}$, Curtose e $\theta_{F_{\mathrm{R}}}$ durante o intervalo de tempo de 2,5 segundos. É possível observar com maior detalhe como os parâmetros se relacionam durante o ciclo de contração do cardiomiócito. 


\subsection{Potência de contração}

As forças de tração que os cardiomiócitos realizam no substrato durante o ciclo de contração podem apresentar orientação radial, que está associada à trações de contração e dilatação, assim como, à forças de tração com orientação circunferencial, que está associada à trações que geram torque (Butler et al., 2002; Zielinski et al., 2013). Por exemplo, uma força de tração positiva na direção do eixo $y, T_{y}$, aplicada em uma posição da coordenada $x$ positiva, contribui para um torque no sentido anti-horário, que é proporcional à $x T_{y}$ (Butler et al., 2002; Zielinski et al., 2013).

Uma vez que o torque resultante exercido pela célula sobre o substrato seja zero, fazendo uma integral sobre a área da célula, pode-se obter uma matriz do momento contrátil, M, (Butler et al., 2002; Zielinski et al., 2013). Onde, cada componente é dada por:

$$
M_{i j}=\frac{1}{2} \int d^{2} r\left(x_{i} T_{j}(r)+x_{j} T_{i}(r)\right)
$$

sendo, $r$ a posição na superfície do gel, $x$ a distância do centro de massa da célula ao ponto de aplicação de força na superfície do gel e $T$ à força de tração (Butler et al. 2002. Zielinski et al., 2013).

A contribuição de todas as forças de tração para a contração e dilatação do substrato, nas direções $x$ e $y$, é dado pelo momento contrátil resultante $\left(M_{R}\right)$, que é uma forma de obter-se uma grandeza relacionada à energia de contração ou relaxamento devido as forças de tração. $\mathrm{O} M_{\mathrm{R}}$ é uma medida escalar da força de tração e é dado por:

$$
M_{\mathrm{R}}=M_{x x}+M_{y y}
$$

O comportamento do $M_{\mathrm{R}}$ durante o ciclo de contração, para uma amostra de cardiomiócito WT pode ser visto na Fig. 3.9. Os asteriscos em vermelho representam os pontos de máximo e os azuis de mínimo do $M_{\mathrm{R}}$. 


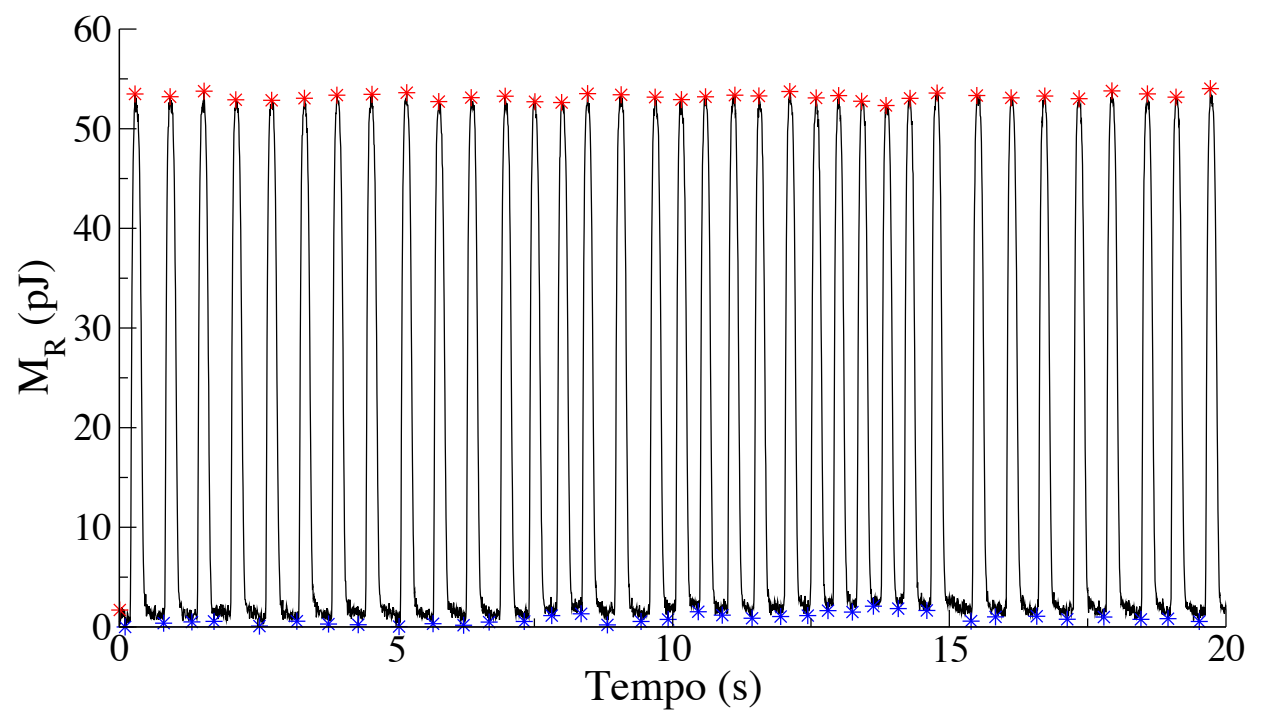

Figura 3.9: Nesse gráfico, mostra-se o comportamento do $M_{R}$ durante o ciclo de contração para uma amostra de cardiomiócito da linhagem WT. Os asteriscos em vermelho representam os pontos de máximo e os azuis, os de mínimo do $M_{R}$.

Dessa forma, foi possível ajustar uma sigmoide para obtenção da curva de contração e relaxamento do $M_{R}$. Calculando a derivada em função do tempo das curvas de ajuste da sigmoide do $M_{R}$ obteve-se a potência de contração e relaxamento. A Fig. 3.10ilustra as curvas de ajuste do $M_{\mathrm{R}}$ e de sua derivada (potência), para um intervalo de tempo de dois segundos.
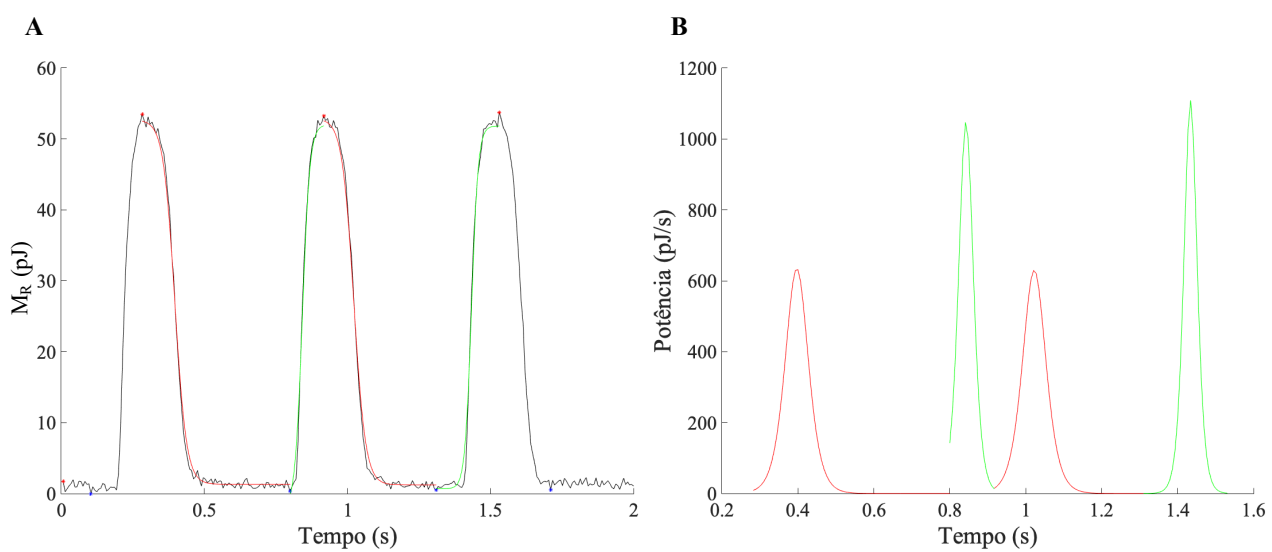

Figura 3.10: A: Comportamento do $M_{\mathrm{R}}$ com ajuste da sigmoide. A curva em vermelho representa o ajuste durante o relaxamento e a curva em verde, o ajuste durante a contração. B: A figura apresenta as curvas de ajuste da derivada do $M_{R}$. A curva em vermelho representa a potência de relaxamento e a curva verde, a potência de contração. 
O ajuste da potência pela derivada do $M_{R}$ foi automatizado pelo nosso grupo de pesquisa e aplicada em um trabalho, visando investigar a influência de duas metodologias de extração de cardiomiócitos de ratos neonatos em suas propriedades mecânicas (Jensen et al. 2018)). A pesquisa foi realizada utilizando o TFM como metodologia experimental e, entre outras análises, a potência de contração e relaxamento foi utilizada para estudar as propriedades mecânicas dos cardiomiócitos em cada tipo de extração (maiores detalhes sobre esse trabalho podem ser vistos em (Jensen et al., 2018)).

Basicamente o ajuste da curva, em termos do tempo, é feito pela função senoidal $S_{i}(t)$, dada por:

$$
S_{i}(t)=A_{i} \frac{1}{1+e^{-\beta_{i}\left(t-t_{i}\right)}}+C_{i}
$$

onde, $A_{i}$ é a amplitude, $C_{i}$ é a base, relacionado ao platô inferior da curva, té o tempo, $t_{i}$ é o intervalo de tempo onde ocorre a inflexão da curva e $\beta_{i}$ é o expoente da sigmoide, que determina a velocidade da função. No ponto de inflexão da curva, $t=t_{i}$, que é o instante onde a primeira derivada fornece o ponto de potência máxima.

\subsection{Análise de Fourier}

A transformada de Fourier (TF) é uma ferramenta versátil e pode ser utilizada em diversas áreas, como: Espectroscopia, ressonância magnética, processamento de sinais e no contexto biológico,quando os dados são adquiridos no domínio do tempo (Donoho et al., 2006; Katoh et al., 2002, Harris, 1978). Nesse contexto, a TF pode ser utilizada para estimar alinhamento de fibras, forças de tração, matriz extracelular e para obtenção do espectro de frequências de um determinado sinal (Kemeny e Clyne, 2011; Karlon et al. 1999: Butler et al., 2002).

Para se identificar as frequências que compõem um sinal, composto por uma distribuição discreta de dados com $N$ pontos, a TF $f(x)$ é calculada da seguinte forma:

$$
F(\omega)=\sum_{x=0}^{N-1} f(x) \exp (-i \omega x),
$$

sendo $x$ uma variável que depende da técnica experimental utilizada para obtenção dos dados e $\omega$ a frequência, que pode assumir os seguintes valores: 


$$
\omega=2 \pi \frac{k}{N}, k=0,1, \ldots, N-1
$$

onde $k$ é chamado de "índice de frequência".

A TF foi utilizada em nosso trabalho para identificar o espectro de frequência relacionado ao comportamento da $F_{\mathrm{T}}$ ao longo do tempo. A Fig. 3.11 ilustra o espectro de frequências obtido pela TF dos dados da $F_{\mathrm{T}}$ da Fig. 3.2.
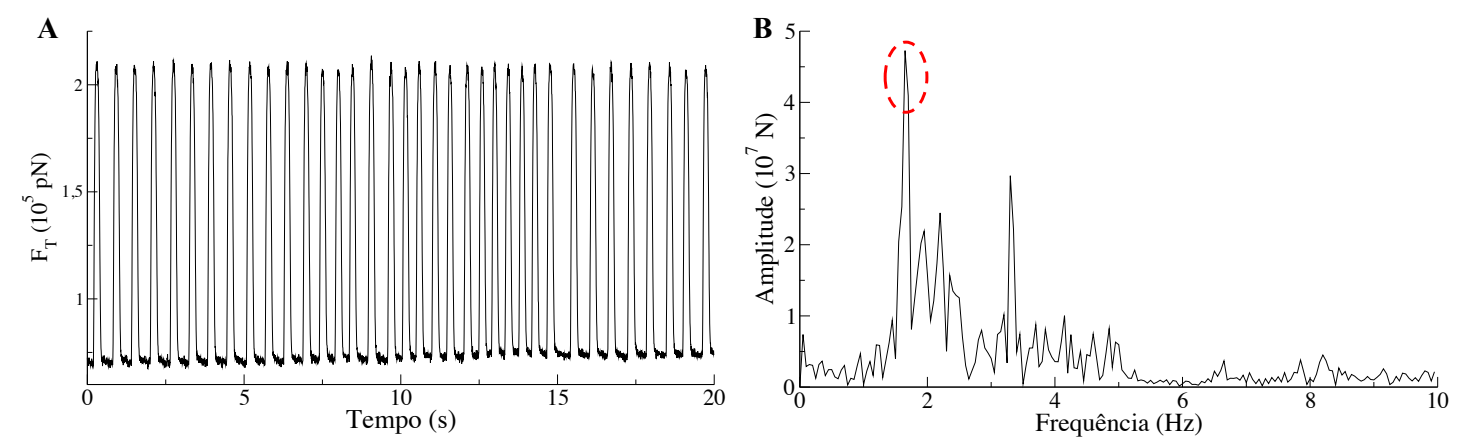

Figura 3.11: A: Comportamento da $F_{\mathrm{T}}$ obtido para uma amostra de cardiomiócito da linhagem KO-CRP3. B: TF da $F_{\mathrm{T}}$ mostrada em (A). Foi evidenciado no círculo em vermelho o pico máximo da distribuição da frequência, que fica em torno de $1.7 \mathrm{~Hz}$.

A distribuição de frequências da Fig. 3.11 B ressalta, basicamente, dois picos distintos de frequências da $F_{\mathrm{T}}$ da Fig. 3.11 A, um dominante, evidenciado em vermelho, próximo de $1.7 \mathrm{~Hz}$, e outro, com amplitude menor, em torno de $3.2 \mathrm{~Hz}$, além de um ruído em outras frequências. Com esse gráfico é possível fazer uma análise da frequência de pulsação do cardiomiócito e verificar se existe um valor de frequência dominante durante o ciclo de contração. Em seguida, esses dados foram ajustados em um histograma para poder fazer uma comparação entre os pontos de frequências máximas das linhagens de cardiomiócitos no estado basal e após a aplicação do isoproterenol, que será apresentado na seção de Resultados (sec.4.1).

\subsection{Análise das flutuações}

Conforme mostrado até agora, percebe-se que diversos parâmetros podem ser obtidos a partir do comportamento da $F_{\mathrm{T}}$ durante o ciclo de contração, como, por exemplo: alinhamento das forças, Curtose, Potência de contração e relaxamento, frequência entre outros. Ao longo das análises, percebeu-se que o comportamento da $F_{\mathrm{T}}$, para alguns cardiomiócitos, apresentavam irregularidades, conforme pode ser visto na Fig.3.12. 
Durante os experimentos, alguns cardiomiócitos pararam de pulsar, ou então, pulsavam de forma irregular, o que gerou alguns dos comportamentos apresentados abaixo. $\mathrm{O}$ comportamento da $F_{\mathrm{T}}$ para o cardiomiócito da Fig.3.12.(A) é o esperado e considerado como regular.
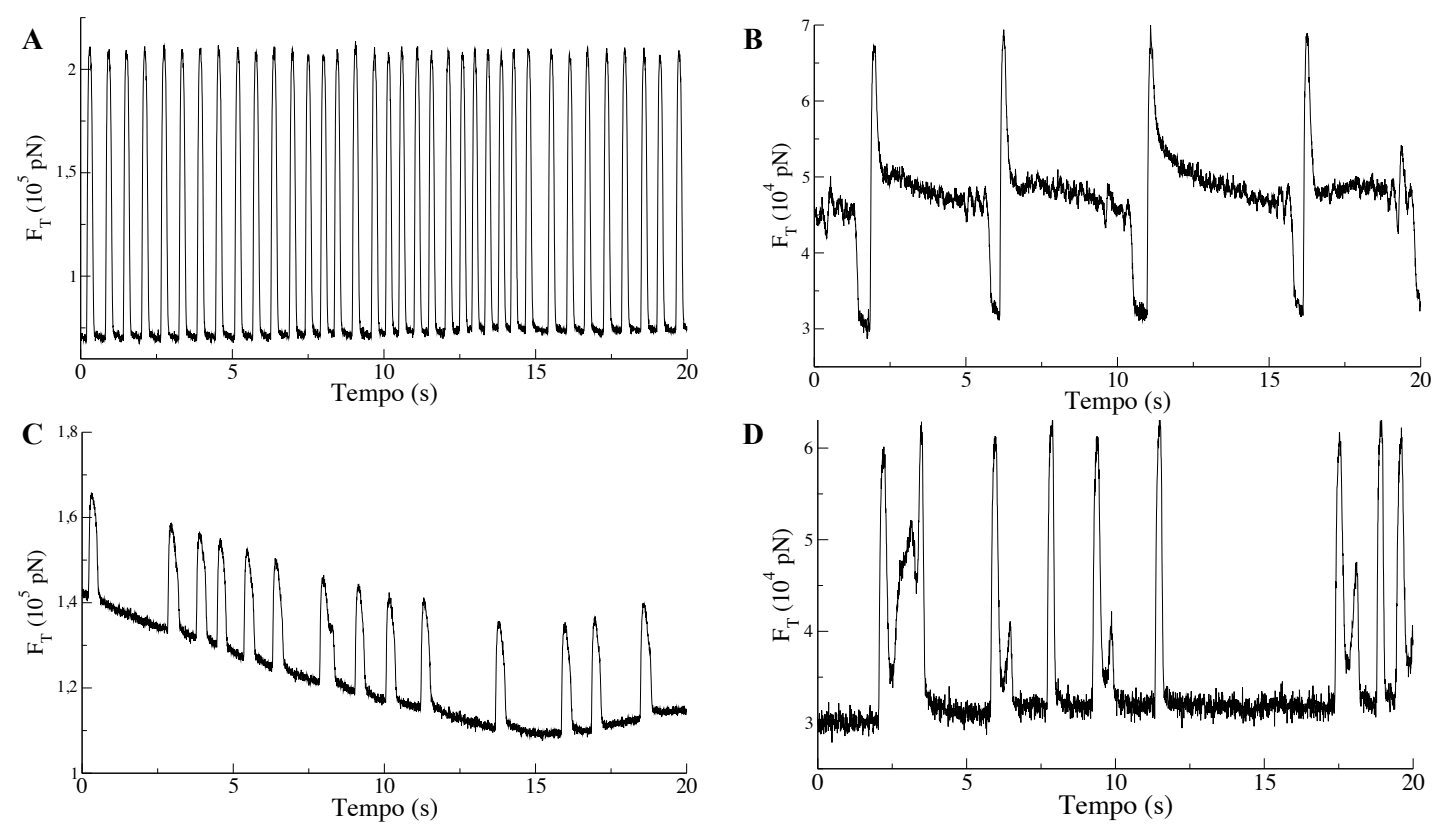

Figura 3.12: A: Exemplo do comportamento da $F_{\mathrm{T}}$ para uma amostra de cardiomiócito da linhagem KO-CRP3. Esse comportamento foi considerado regular por não apresentar grandes variações nos pontos de força máxima e mínima e nem no período de oscilação. B: Exemplo do comportamento da $F_{\mathrm{T}}$ obtido para uma amostra de cardiomiócito da linhagem KO-CRP3. Pode-se ver que existe uma flutuação no período de pulsação. C: Exemplo do comportamento da $F_{\mathrm{T}}$ obtido para uma amostra de cardiomiócito da linhagem WT. Pode-se verificar que existe uma flutuação na amplitude de oscilação e no período. D: Exemplo do comportamento da $F_{\mathrm{T}}$ em uma amostra da linhagem WT. Nesse tipo de comportamento nota-se, novamente, uma flutuação na amplitude de oscilação e no período.

Nesse sentido, foi desenvolvida uma metodologia capaz de identificar algumas dessas flutuações. A metodologia desenvolvida para a identificação das flutuações tomou por base o trabalho realizado por (Penttinen et al., 2015). Nesse trabalho, os autores analisaram a propagação de cálcio em cardiomiócitos de células pluripotentes e ajustaram um gráfico do seu comportamento ao longo do tempo. Segundo os autores, a propagação de cálcio de forma irregular pelos cardiomiócitos está associada a desordens e insuficiência cardíaca (Penttinen et al., 2015). Desse modo, os autores desenvolveram uma ferramenta computacional, "AnomalyExplorer" que identifica o tipo de propagação de cálcio detectado no cardiomiócito e o classifica segundo alguns critérios de anormalidade (Penttinen 
et al., 2015).

Com base nesse trabalho, foi possível desenvolver critérios para que, dentro das nossas análises, fosse identificado padrões de flutuação no comportamento da $F_{\mathrm{T}}$ ao longo do tempo. Com os critérios desenvolvidos, foi possível identificar flutuações na amplitude e no período de oscilação. Os detalhes de como foram identificadas essas flutuações estão descritos a seguir.

\subsubsection{Gráfico de boxplot}

O gráfico de boxplot, ou diagrama de caixas, é representado por cinco valores principais: os limites inferior e superior, os quartis inferior e superior e a mediana (Kampstra et al., 2008; Frigge et al. 1989). Esses valores sintetizam de forma simples toda a distribuição dos dados, além de ser uma representação mais clara e direta para se comparar a distribuição dos dados analisado dentro dos grupos de cardiomiócitos dos experimentos. A Fig. 3.13 detalha os cinco valores principais que podem ser observados no gráfico de boxplot. Para isso, utilizou-se como exemplo a metodologia desenvolvida para obtenção da flutuação do período de pulsação em torno da média, conforme apresentado na Fig. 3.15 .

Ao apresentar os dados em um gráfico de boxplot, estamos interessados em ver como esses dados estão distribuídos. Analisando a Fig. 3.13(A), a reta no centro da caixa indica a mediana da distribuição. A caixa do boxplot representa $50 \%$ dos dados centrais da distribuição, onde o quartil inferior representa 25\% dos dados de menores valores, já o quartil superior representa 75\% dos dados de menores valores. As linhas fora da caixa, que vão até o limite inferior e superior, representam as caudas da distribuição. Sendo a amplitude da caixa dada por: $A m p=($ terceiro quartil $)-($ primeiro quartil $)$. Os limites inferior e superior são dados por:

$$
\text { Limite inferior }=\text { primeiro quartil }-1.5 \times A m p,
$$

já o limite superior é dado por,

$$
\text { Limite superior }=\text { terceiro quartil }+1.5 \times A m p \text {. }
$$

Para o cálculo dos quartis, inicialmente devemos organizar os dados em ordem crescente. Assim, podemos calcular a mediana que é o valor que separa os dados em 
duas metades. O cálculo dos quartis é dado pela mediana dessas metades, onde, o quartil inferior é a mediana dos dados da metade de baixo e o quartil superior é a mediana da metade de cima. Dessa forma, pode-se verificar como o parâmetro analisado se comporta entre os grupos de cardiomiócitos analisados, WT, WT-ISO, KO-CRP3 e KO-CRP3-ISO.

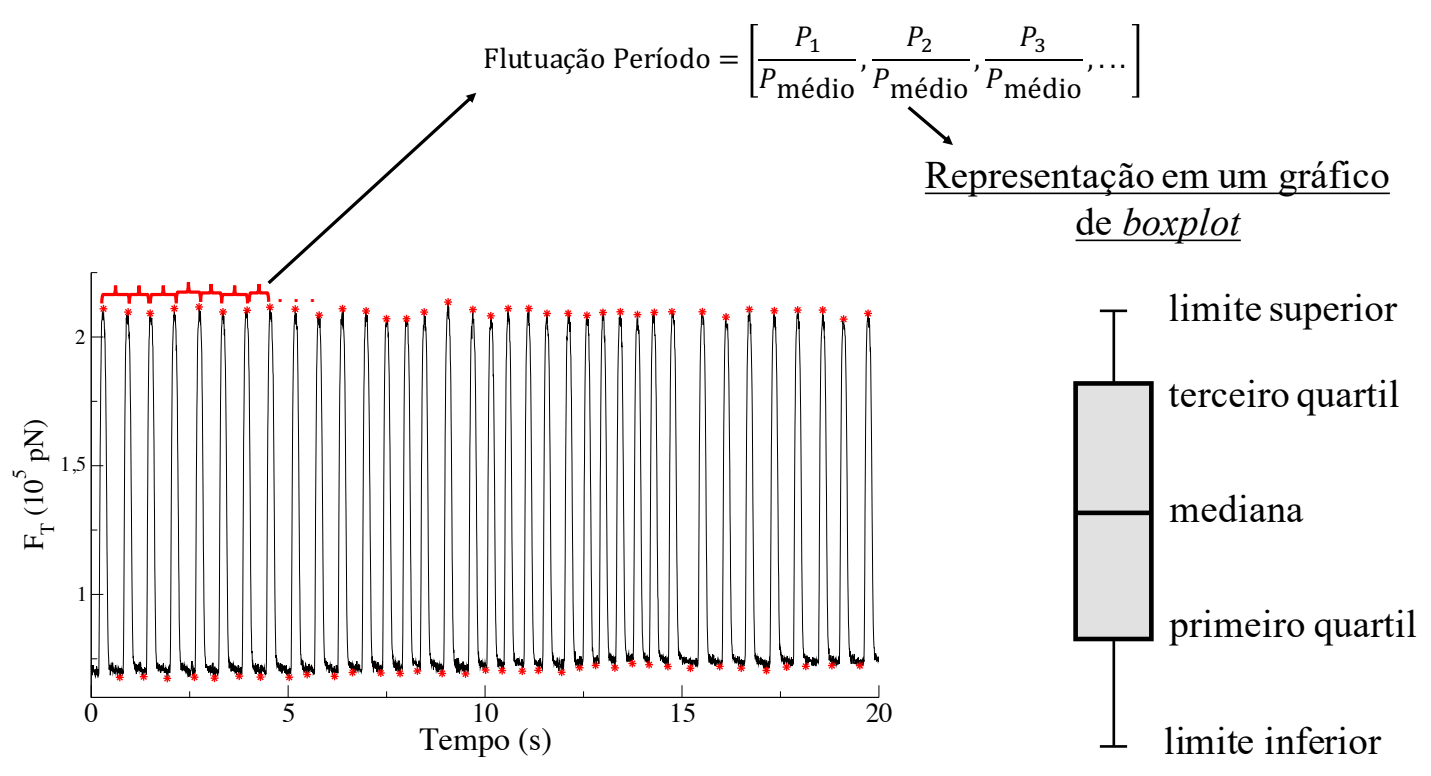

Figura 3.13: Detalhamento dos cinco principais valores estatísticos no gráfico de boxplot. Foi utilizado como exemplo a metodologia para obtenção da flutuação do período de pulsação do cardiomiócito em torno da média, conforme mostrado na Fig. 3.15

\subsubsection{Flutuação na amplitude}

Pela curva da $F_{\mathrm{T}}$ obtida para cada cardiomiócito analisado foram identificados todos os pontos de $F_{\max }$ e $F_{\min }$ da distribuição. A Amplitude da $F_{\mathrm{T}}$ é dada pela diferença entre os valores de $F_{\max }$ e $F_{\min }$ em sequência. Assim, realizado o cálculo de cada amplitude durante o ciclo de contração do cardiomiócito, obteve-se a amplitude média. A flutuação da amplitude foi calculada dividindo cada valor de amplitude pelo valor médio da distribuição. A partir desses valores, foi gerado um gráfico de boxplot para representar a distribuição das flutuações de cada cardiomiócito para linhagem WT e KO-CRP3 (maiores detalhes do gráfico de boxplot pode ser visto na sec. 3.5.1). O gráfico da Fig. 3.14 apresenta essa distribuição para cardiomiócitos da linhagem WT em estado basal. 


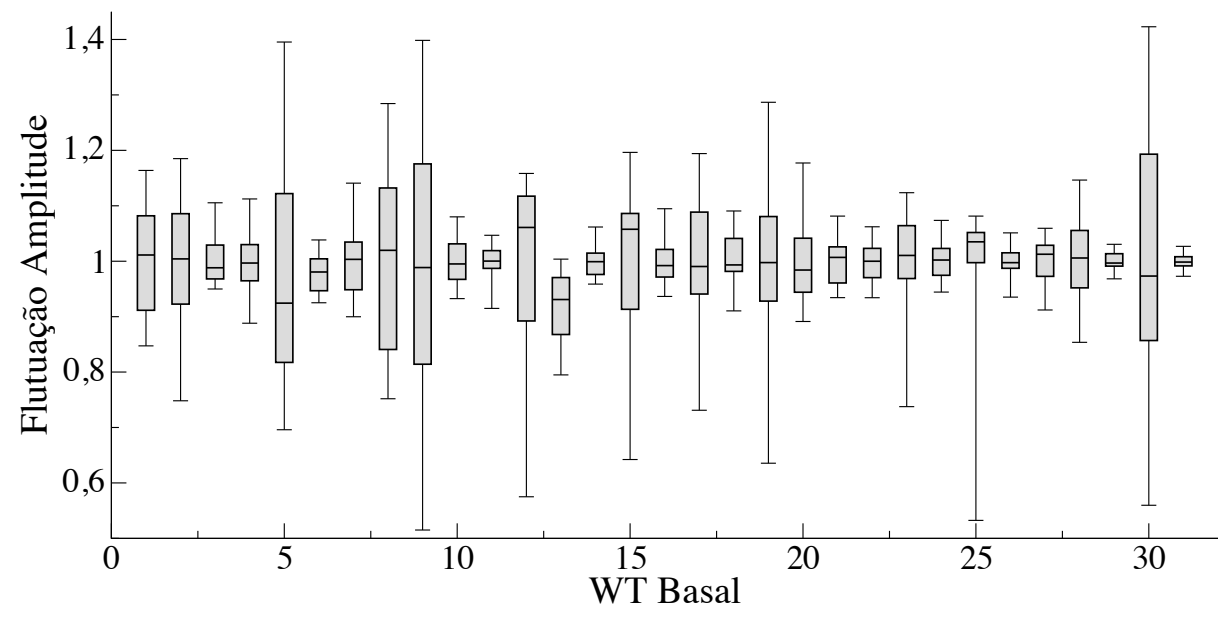

Figura 3.14: Distribuição da flutuação da amplitude normatizada em torno da média para cardiomiócitos da linhagem WT no estado basal. Foram analisados 31 cardiomiócitos dessa linhagem.

Analisando a Fig. 3.14 podemos verificar que para alguns cardiomiócitos a flutuação em torno da média é pequena, o que nos diz que a amplitude da $F_{\mathrm{T}}$ é regular durante o ciclo de contração. No entanto, para alguns cardiomiócitos a flutuação é visivelmente maior em torno da média, mostrando que a amplitude apresenta bastante oscilação em torno da média. Assim, quanto maior o tamanho da caixa do boxplot, maior a sua dispersão.

\subsubsection{Flutuação do Período}

A outra flutuação analisada foi a do período de pulsação. Esse período foi obtido pelo tempo entre um ponto de $F_{\max }$ e o seguinte do gráfico da $F_{\mathrm{T}}$. Com a identificação de cada período de pulsação, obteve-se a flutuação do período da mesma forma que para a flutuação da amplitude, como mostra o esquema da Fig. 3.15. 


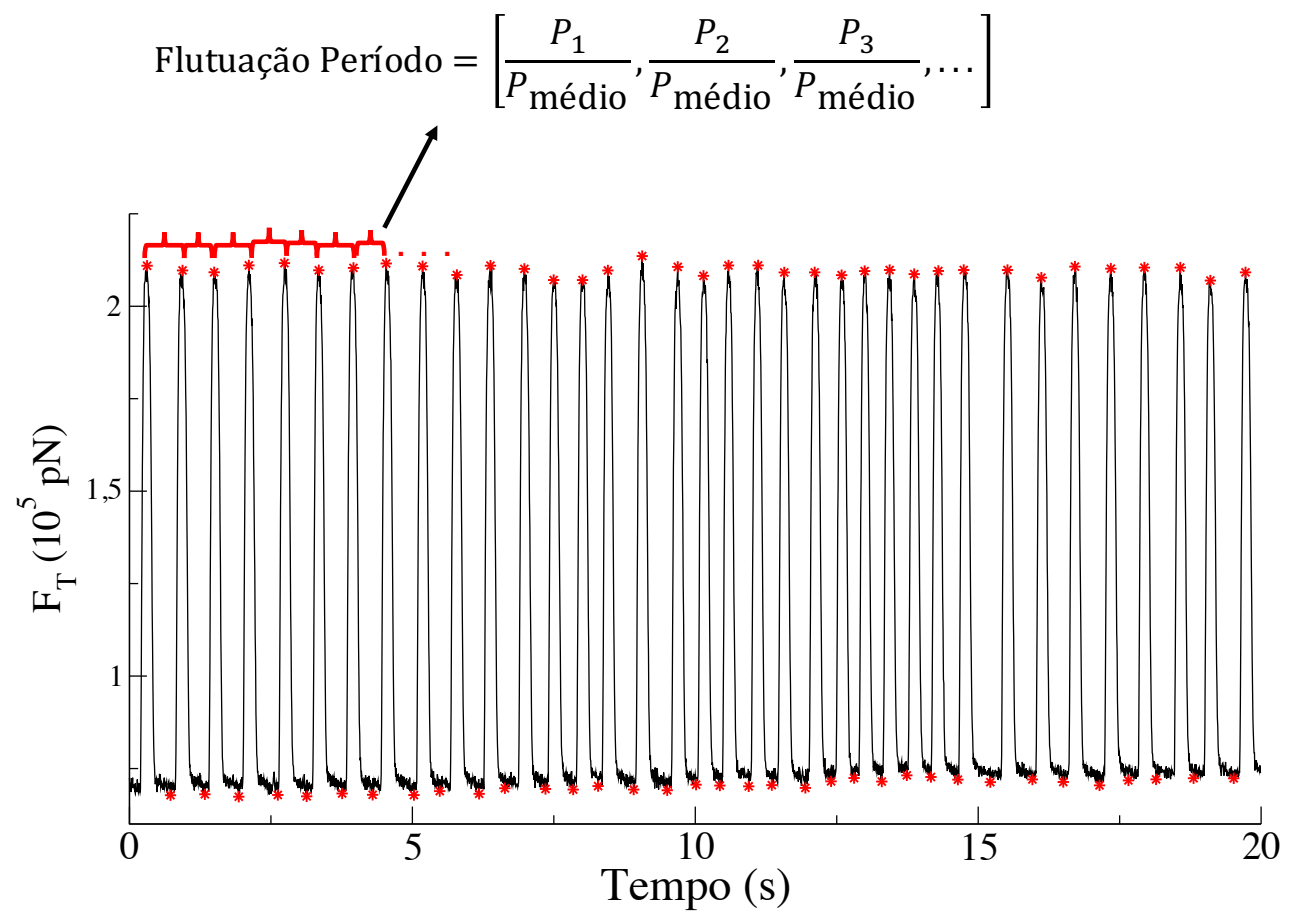

Figura 3.15: Ilustração esquemática da obtenção do período de pulsação do cardiomiócito. Após obtenção de cada período de oscilação, calcula-se o período médio e, dividindo cada valor de período pela média, obtém-se a flutuação do período.

Assim, foi possível obter a distribuição das flutuações do período dos cardiomiócitos de cada linhagem analisado, conforme ilustrado na Fig. 3.16 para a linhagem WT no estado basal.

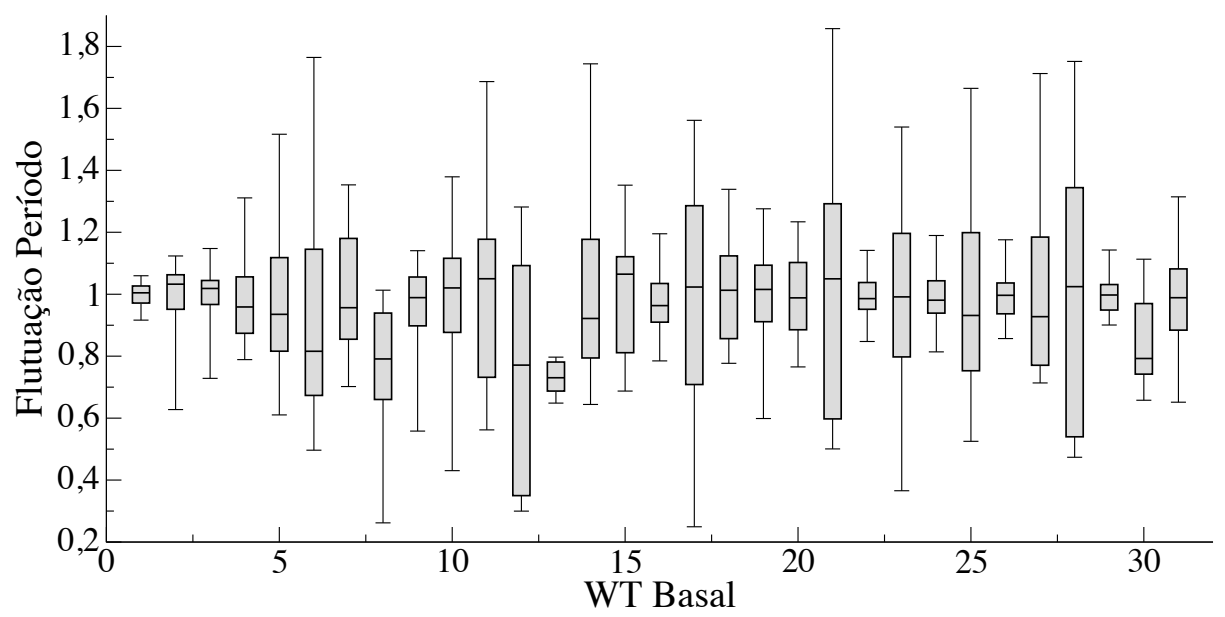

Figura 3.16: Distribuição da flutuação em torno da média do período de pulsação dos cardiomiócitos da linhagem WT no estado basal. 
Pela Fig.3.16 é possível verificar que para a linhagem WT, no estado basal, alguns cardiomiócitos apresentam uma flutuação no período bem regular em torno da média, enquanto que para outros, a flutuação varia consideravelmente. O mesmo foi realizado para o estado estimulado com isoproterenol, assim como, para a linhagem KO-CRP3.

A proposta dessa metodologia é poder avaliar a flutuação de dois parâmetros relevantes do sinal da $F_{\mathrm{T}}$, que podem dificultar determinado tipo de análise. Pretende-se mostrar que essa metodologia pode servir de critério de exclusão de um determinado cardiomiócito dentro de um conjunto. O comportamento da flutuação da amplitude e do período para as linhagens WT e KO-CRP3, no estado basal e estimulado com isoproterenol, será melhor detalhado na seção de resultados. 


\section{Capítulo 4}

\section{Resultados e discussão das ferramentas de análise desenvolvidas}

Nesse capítulo serão mostrados os resultados obtidos pelas ferramentas de análise desenvolvidas no presente trabalho, nas amostras de cardiomiócitos das linhagens WT e KO-CRP3 no estado basal e estimuladas com isoproterenol. Em seguida será feita a discussão desses resultados e, por fim, as conclusões formuladas.

Inicialmente serão apresentados os resultados obtidos. Como dito anteriormente, foi obtido um conjunto de 31 amostras de cardiomiócitos da linhagem WT, e 27 da linhagem $\mathrm{KO}-\mathrm{CRP} 3$, de forma pareada, no estado basal e com isoproterenol.

\subsection{Resultados}

\subsubsection{Curtose}

Para cada cardiomiócito analisado foi obtida a Curtose de cada imagem adquirida ao longo da filmagem pela Eq 3.8. Com esses dados foi possível gerar um gráfico da Curtose ao longo do tempo (Fig. 3.5), assim como um histograma da Curtose para cada cardiomiócito analisado, conforme exemplo da Fig.4.1. 

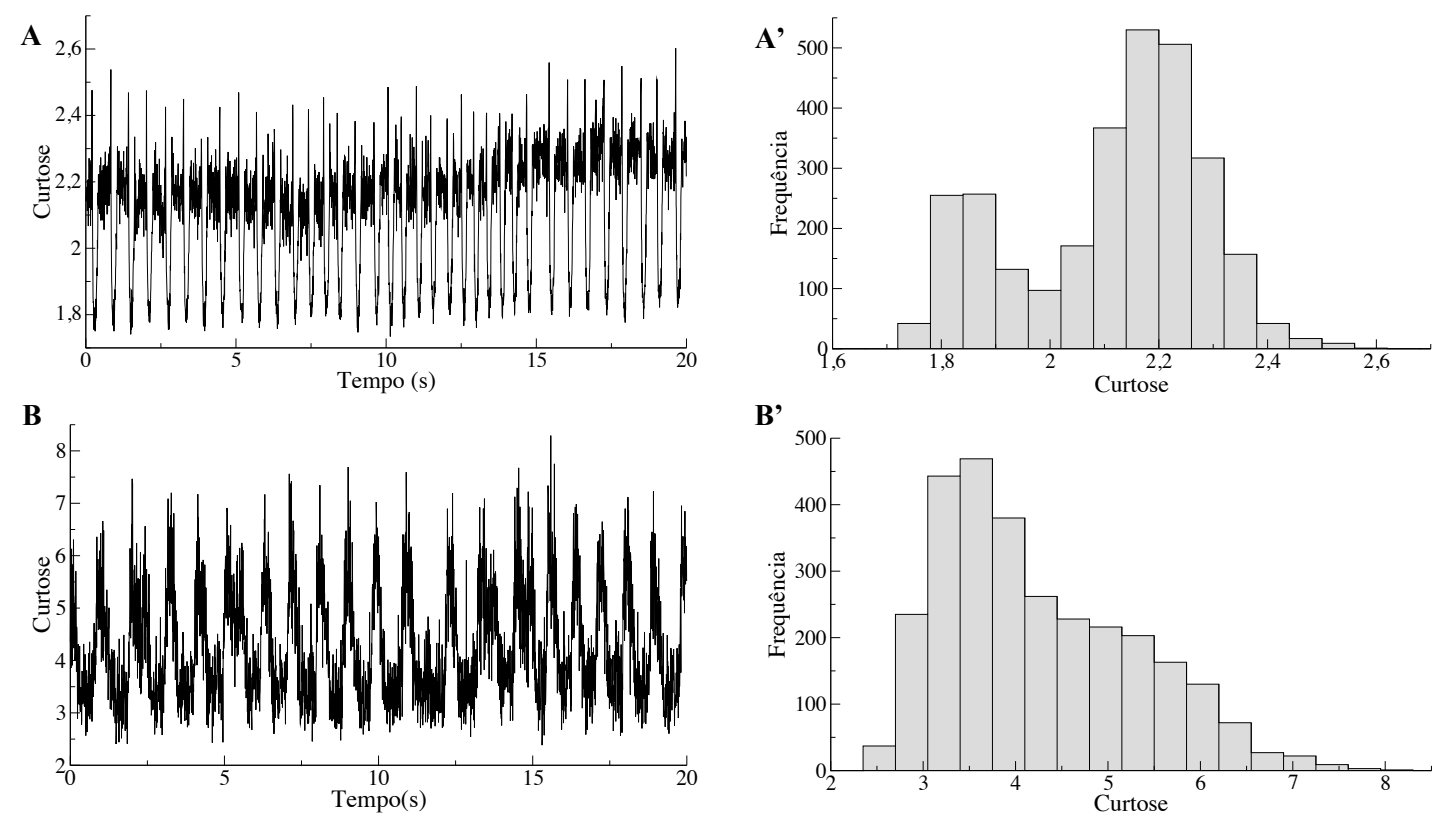

Figura 4.1: A: Comportamento da Curtose durante o ciclo de contração para uma amostra da linhagem KO-CRP3. A': Histograma da Curtose referente ao mesmo cardiomiócito de (A), onde, todos os pontos, incluindo o pico máximo da distribuição, apresentam um valor de Curtose menor do que 3, indicando um baixo grau de alinhamento das forças de tração. B: Comportamento da Curtose durante o ciclo de contração para uma amostra da linhagem WT. B': Histograma da Curtose referente ao mesmo cardiomiócito de (B), onde, a maioria dos pontos, incluindo o pico máximo da distribuição, apresentam um valor de Curtose maior do que 3, indicando um alto grau de alinhamento das forças de tração.

Serão apresentadas três abordagens diferentes que foram utilizados para analisar o grau de alinhamento das forças de tração. Inicialmente, para cada histograma gerado foi identificado a moda da distribuição que representa o valor de Curtose predominante durante o ciclo de contração do cardiomiócito. Em seguida, foi gerado um histograma do valor de Curtose da moda de cada cardiomiócito por linhagem, no estado basal e após a aplicação do isoproterenol, conforme Fig.4.2.

Os histogramas da Fig. 4.2 mostram uma certa semelhança entre as linhagens. No entanto, pode-se perceber que para a linhagem WT, o isoproterenol fez com que mais cardiomiócitos apresentassem um alto grau de alinhamento (Curtose $>3$ ) com relação ao estado basal. O mesmo não ocorre com a linhagem KO-CRP3. O isoproterenol, para essa linhagem, diminuiu levemente o número de cardiomiócitos com alto grau de alinhamento. 

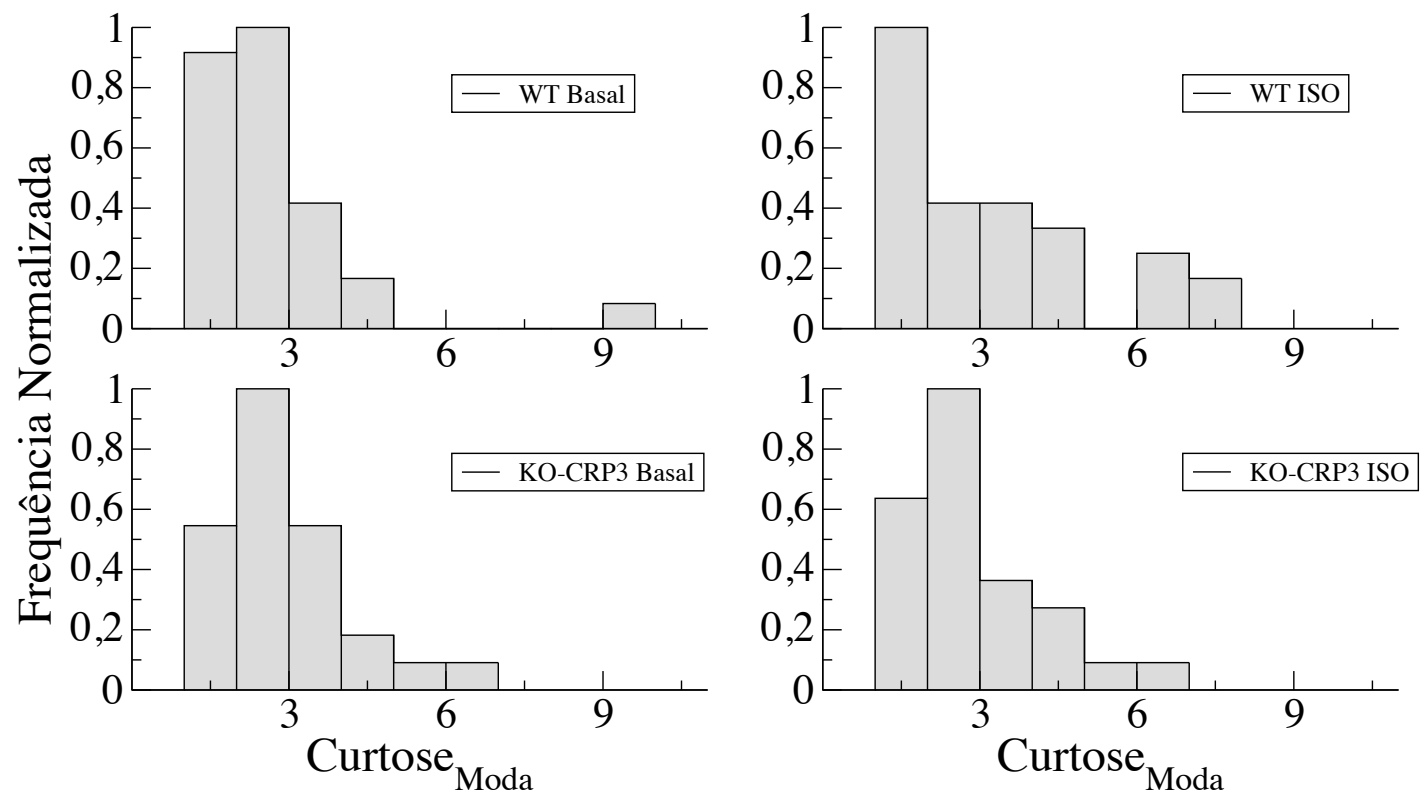

Figura 4.2: O gráfico apresenta o histograma dos valores da Curtose da moda de cada cardiomiócito analisado, organizado por linhagem, no estado basal e após a aplicação do isoproterenol.

Pelos histogramas é possível visualizar a distribuição dos valores de Curtose entre as linhagens, no entanto, não é possível saber como variou o valor de Curtose dos cardiomiócitos do estado basal para com o isoproterenol. Como todas as análises são pareadas, é possível ajustar um gráfico da diferença da Curtose entre o estado basal e com isoproterenol para cada cardiomiócito entre as linhagens, conforme Fig.4.3 


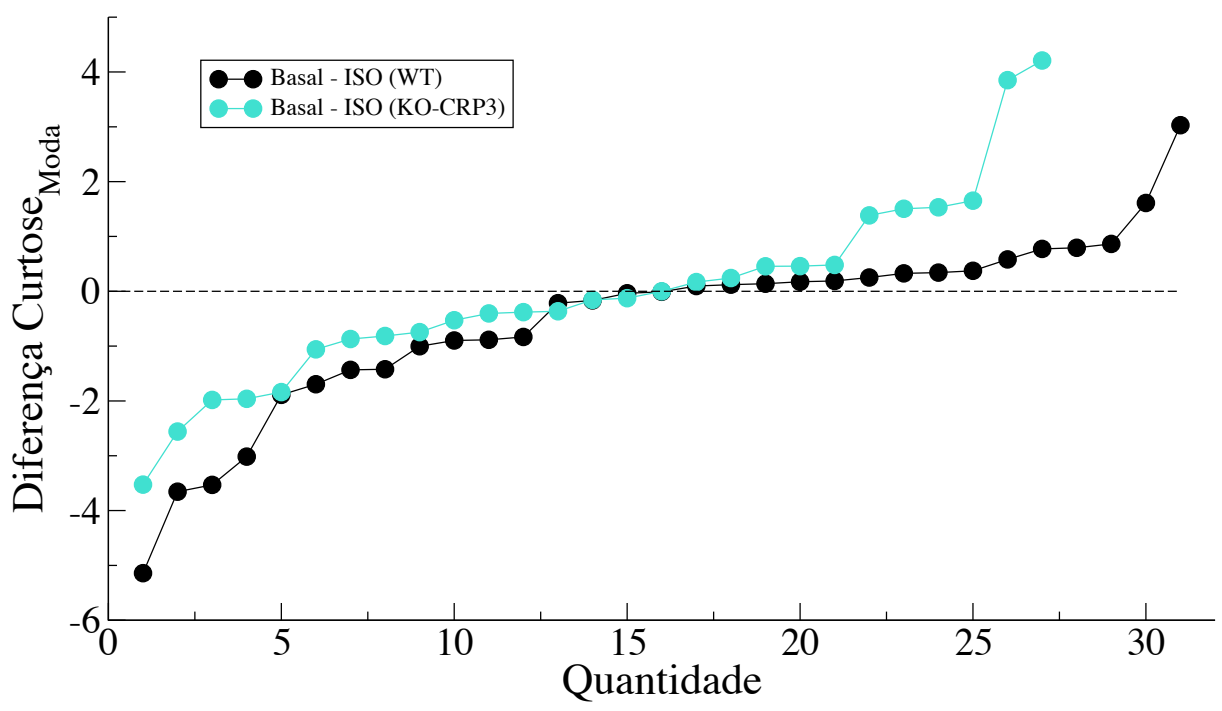

Figura 4.3: O gráfico apresenta a diferença dos valores da Curtose da moda entre o estado basal e com isoproterenol de cada cardiomiócito analisado, organizado por linhagem. Valores menores do que zero indicam que houve um aumento da Curtose com o isoproterenol. Valores maiores do que zero indicam que houve uma diminuição da Curtose com o isoproterenol.

Pela Fig. 4.3 é possível ter uma melhor percepção do efeito do isoproterenol na Curtose da moda. A diferença dos valores de Curtose foi feita de forma pareada e organizada em ordem crescente. Para a linhagem WT, aproximadamente $45 \%$ dos cardiomiócitos aumentaram o valor de Curtose da moda do estado basal para com o isoproterenol, ou seja, a diferença da Curtose foi negativa. Já para a linhagem KO-CRP3, aproximadamente 52 \% dos cardiomiócitos aumentaram o valor da Curtose da moda. Ainda é possível perceber que para alguns cardiomiócitos, de ambas as linhagens, o isoproterenol não teve efeito e a diferença ficou próxima de zero. Enquanto que para outra parte, o isoproterenol diminuiu o valor da Curtose da moda, ou seja, a diferença da Curtose foi positiva.

Para um melhor efeito de comparação, foi organizada uma tabela com a porcentagem de cardiomiócitos de cada linhagem com valores de Curtose da moda acima de três, alto grau de alinhamento, no estado basal e após a aplicação do isoproterenol, conforme Tab.4.1.

A porcentagem apresentada na Tab. 4.1 para a linhagem WT e KO-CRP3, se refere a um total de 31 e 27 cardiomiócitos analisados, respectivamente. É possível verificar 
Tabela 4.1 - Cardiomiócitos com alto grau de alinhamento, referente à moda da distribuição.

\begin{tabular}{l|cc} 
Linhagem & Basal & ISO \\
\hline WT & $\sim 26 \%$ & $\sim 45 \%$ \\
KO-CRP3 & $\sim 37 \%$ & $\sim 33 \%$
\end{tabular}

que para linhagem WT o isoproterenol aumentou em mais de $20 \%$ a quantidade de cardiomiócitos com alto grau de alinhamento, no entanto, para a linhagem KO-CRP3 o mesmo não ocorre, visto que a porcentagem de cardiomiócitos com algo grau de alinhamento reduziu em torno de $4 \%$ após a aplicação do isoproterenol.

As demais análises referem-se à Curtose dos pontos de máximo e mínimo da curva da $F_{\mathrm{T}}$. A Fig.4.4 ilustra a metodologia adotada para o cálculo dessas Curtoses. Após identificado os pontos de máximo e mínimo da curva da $F_{\mathrm{T}}$ ao longo do tempo, obteve-se a Curtose de outros quatro pontos ao redor desses, de forma que para cada asterisco em vermelho na Fig. 4.4 tenha-se cinco ponto de valores de Curtose. Dessa forma, para se obter um valor de Curtose dos pontos de máximo, Curtose ${ }_{\text {Máx }}$, e mínimo, Curtose $e_{\text {Min }}$ para cada cardiomiócito, foi calculado a média das Curtoses dos pontos de máximo ou mínimo, conforme exemplificado na Fig.4.4.

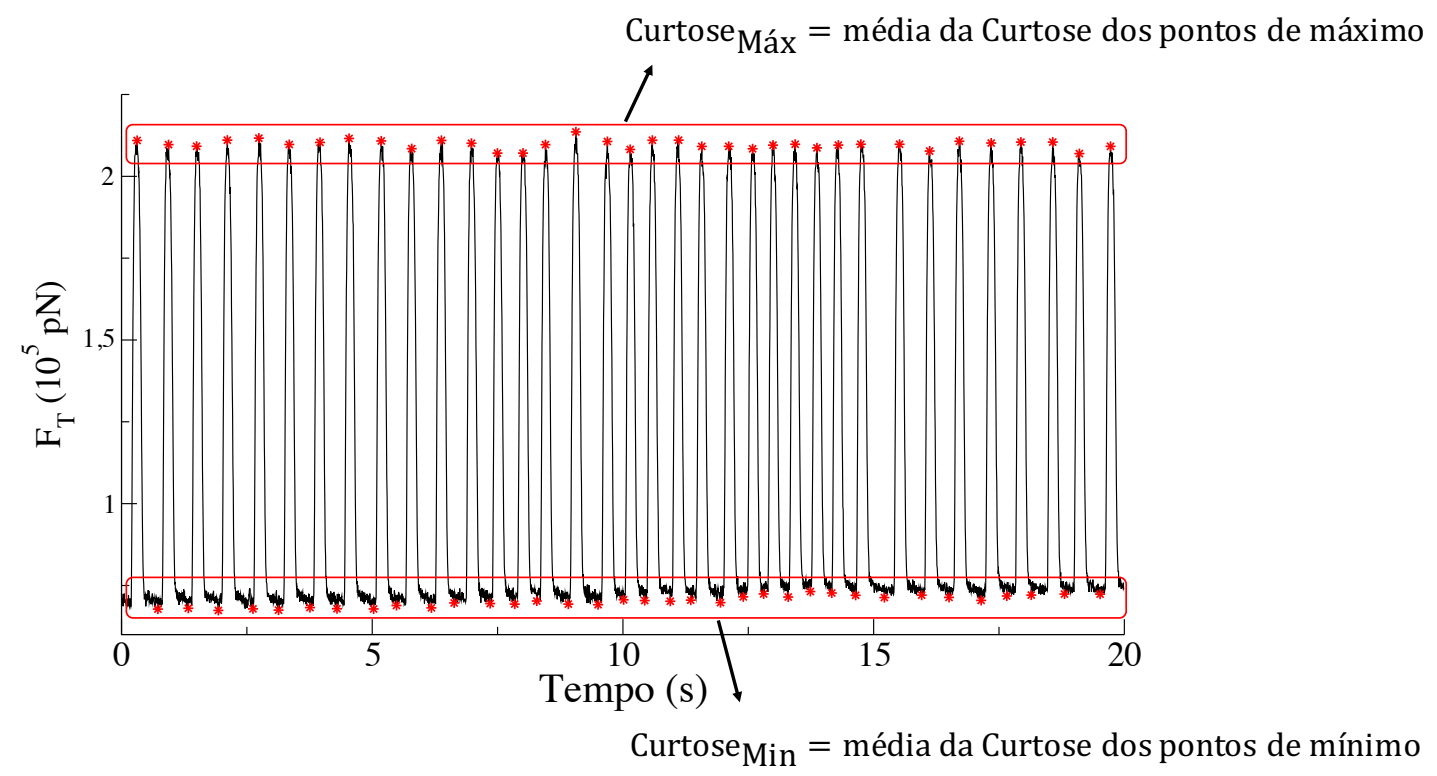

Figura 4.4: O gráfico apresenta um esquema que exemplifica o cálculo realizado para obtenção da Curtose dos pontos de máximo e mínimo da $F_{\mathrm{T}}$. Para cada ponto de máximo e mínimo da $F_{\mathrm{T}}$ têm-se cinco valores de Curtose. Assim, para cada cardiomiócito foi calculado a Curtose $e_{\text {Máx }}$ que é a média das Curtoses dos pontos de máximo, e a Curtose ${ }_{\text {Min, que é a }}$ média das Curtoses dos pontos de mínimo. 
Com isso foi possível gerar um histograma da Curtose dos pontos de máximo e mínimo da $F_{\mathrm{T}}$ para cada linhagem de cardiomiócito, no estado basal e com isoproterenol. A Fig.4.5, apresenta a histograma da Curtose dos pontos de máximo, Curtose Máx $_{\text {. }}$
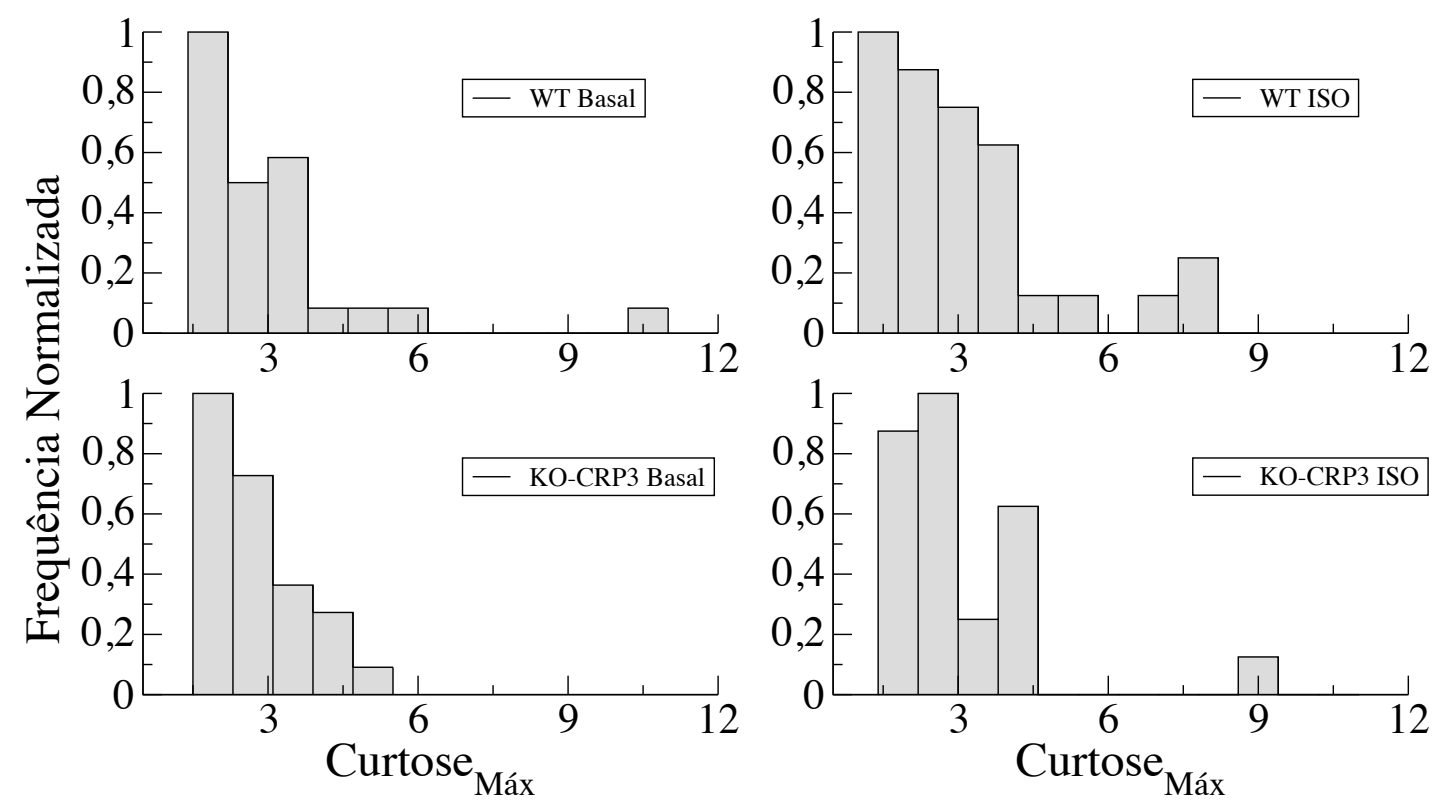

Figura 4.5: O gráfico apresenta o histograma dos valores de curtose máxima de cada cardiomiócito analisado, organizado por linhagem, no estado basal e após a aplicação do isoproterenol.

Da mesma forma que realizado para análise da Curtose da moda, foi ajustado um gráfico da diferença da Curtose dos pontos de máximo entre o estado basal e com isoproterenol, conforme Fig.4.6.

Para a Curtose dos pontos de máximo, pela Fig.4.6, a quantidade de cardiomiócitos da linhagem WT que tiveram seu valor aumentado com o isoproterenol, foi de aproximadamente 39\%. Já para a linhagem KO-CRP3, esse valor foi de aproximadamente 37\%. Fazendo uma contagem do número de pontos maiores do que zero, para a linhagem WT, percebe-se que é próximo a quantidade de valores menores do que zero, com oito valores de Curtose bem próximas de zero, aproximadamente 26 \% dos cardiomiócitos, ou seja, que não foram afetadas pelo isoproterenol.

Para a linhagem KO-CRP3, 4 valores de Curtose dos pontos de máximo ficaram bem próximos de zero, aproximadamente 15 \% dos cardiomiócitos. A maioria, aproximadamente $48 \%$, apresentaram uma diferença maior do que zero, ou seja, o isoproterenol diminuiu o valor da Curtose para a maioria dos cardiomiócitos dessa linhagem. Para uma 


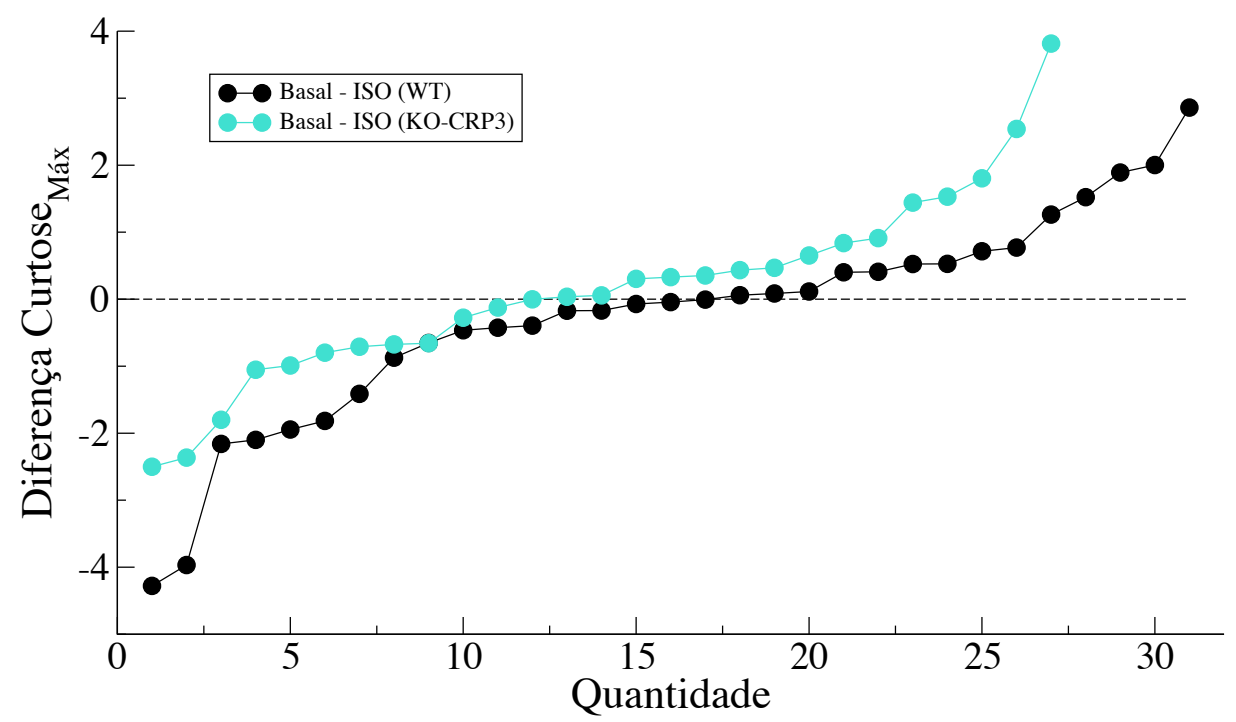

Figura 4.6: O gráfico apresenta a diferença dos valores da Curtose dos pontos de máximo entre o estado basal e com isoproterenol de cada cardiomiócito analisado, organizado por linhagem. Valores menores do que zero indicam que houve um aumento da Curtose com o isoproterenol. Valores maiores do que zero indicam que houve uma diminuição da Curtose com o isoproterenol.

melhor comparação, foi organizada uma tabela com a porcentagem de cardiomiócitos de cada linhagem com alto grau de alinhamento (Curtose $>3$ ), no estado basal e após a aplicação do isoproterenol, conforme Tab.4.2.

Tabela 4.2 - Cardiomiócitos com alto grau de alinhamento, referente aos pontos de máximo da $F_{\mathrm{T}}$.

\begin{tabular}{l|cc} 
Linhagem & Basal & ISO \\
\hline WT & $\sim 35 \%$ & $\sim 42 \%$ \\
KO-CRP3 & $\sim 33 \%$ & $\sim 30 \%$
\end{tabular}

Analisando os dados da Tab.4.2, novamente, percebe-se que o alto grau de alinhamento aumenta com o isoproterenol na linhagem WT, e diminui na linhagem KO-CRP3. Quando se compara os valores da Tab.4.2 com os da Tab. 4.1. vê-se que a porcentagem de cardiomiócitos com alto grau de alinhamento no estado basal é maior nos pontos de máximo na linhagem WT, enquanto que, para a linhagem KO-CRP3 é o contrário. Já com isoproterenol, os valores são próximos, tanto nos pontos de máximo, quanto dos da moda, em ambas as linhagens.

Por fim, o gráfico da Fig. 4.7apresenta o histograma da Curtose dos pontos de mínimo 
da $F_{\mathrm{T}}$, Curtose $_{\text {Min, }}$ que segue a mesmo cálculo para obtenção da Curtose Máx
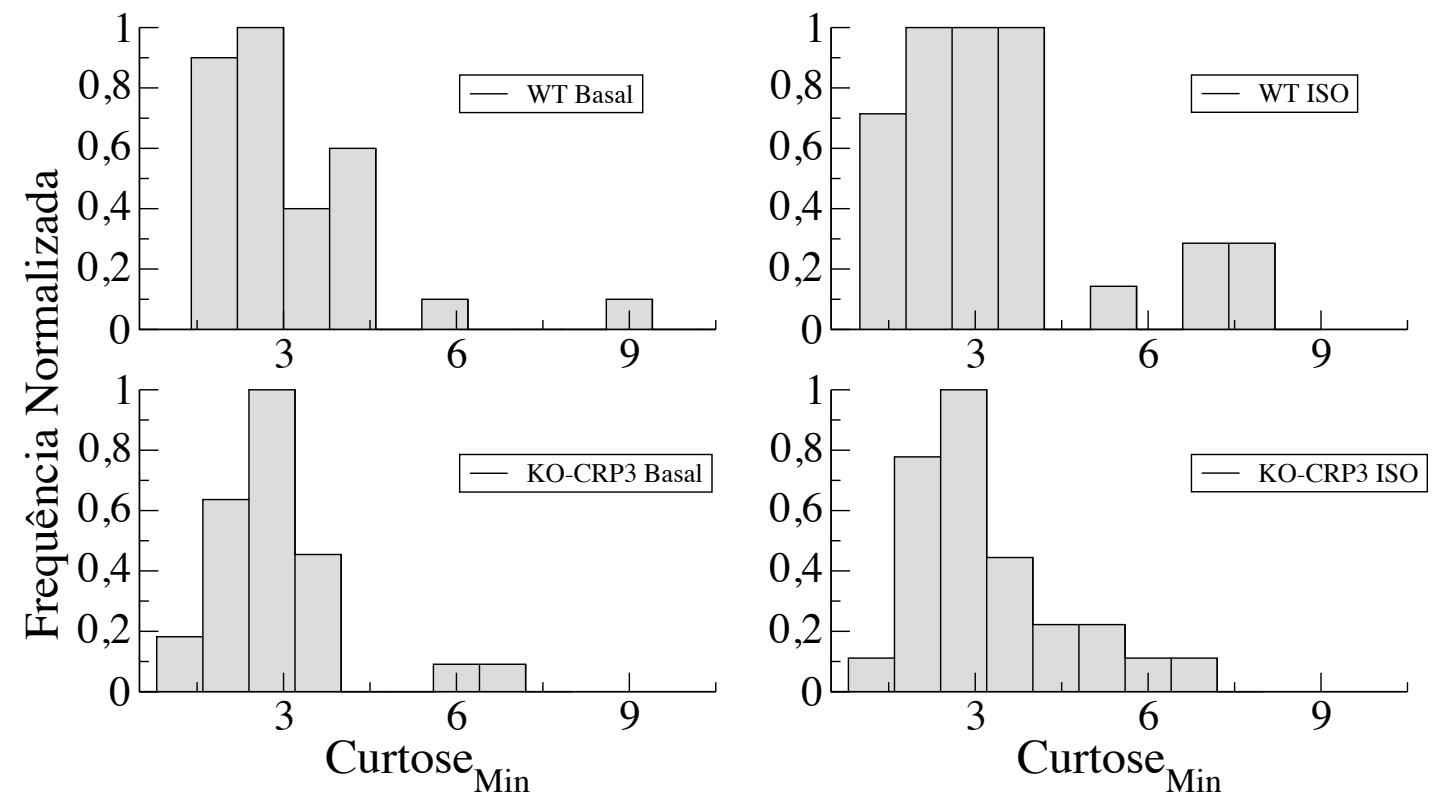

Figura 4.7: O gráfico apresenta o histograma dos valores de curtose mínima de cada cardiomiócito analisado, organizado por linhagem, no estado basal e após a aplicação do isoproterenol.

Assim como anteriormente, foi ajustado um gráfico da diferença da Curtose dos pontos de mínimo entre o estado basal e com isoproterenol, de forma pareada e crescente, para ambas as linhagens de cardiomiócitos, conforme Fig. 4.8 .

Por esse gráfico, é possível verificar que para a linhagem WT, alguns pontos estão bem próximos de zero, ou seja, não apresentaram variação na Curtose dos pontos de mínimo. No entanto, aproximadamente a mesma quantidade de cardiomiócitos aumentaram ( 39\%) e diminuíram ( 42\%) seu valor de Curtose. Já para a linhagem KO-CRP3, mais pontos ficaram próximos de zero do que a linhagem WT, no entanto, aproximadamente 48 \% dos cardiomiócitos aumentaram o valor da Curtose com o isoproterenol, enquanto que aproximadamente $26 \%$ reduziram seu valor. 


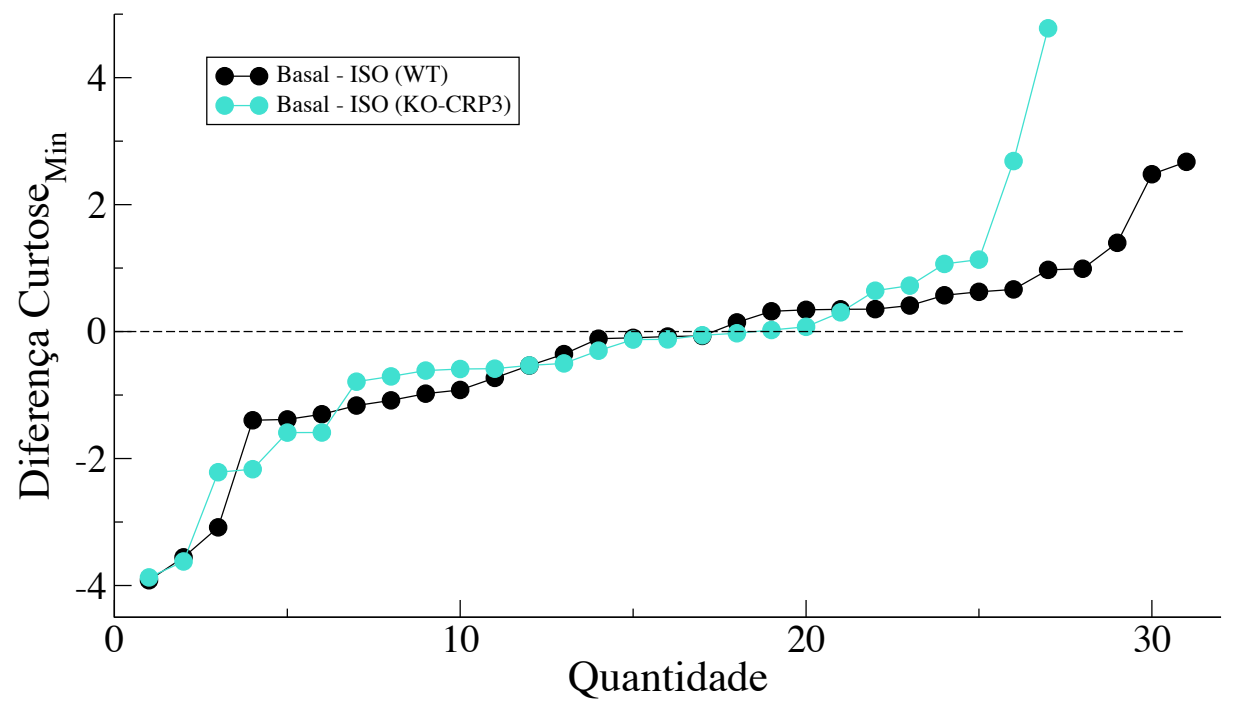

Figura 4.8: O gráfico apresenta a diferença dos valores da Curtose dos pontos de mínimo entre o estado basal e com isoproterenol de cada cardiomiócito analisado, organizado por linhagem. Valores menores do que zero indicam que houve um aumento da Curtose com o isoproterenol. Valores maiores do que zero indicam que houve uma diminuição da Curtose com o isoproterenol.

Da mesma forma que anteriormente, foi organizada uma tabela com a porcentagem de cardiomiócitos de cada linhagem com alto grau de alinhamento (Curtose > 3), no estado basal e após a aplicação do isoproterenol, conforme Tab.4.3

Tabela 4.3 - Cardiomiócitos com alto grau de alinhamento, referente aos pontos de mínimo da $F_{\mathrm{T}}$.

\begin{tabular}{l|cc} 
Linhagem & Basal & ISO \\
\hline WT & $\sim 39 \%$ & $\sim 45 \%$ \\
KO-CRP3 & $\sim 42 \%$ & $\sim 52 \%$
\end{tabular}

Analisando os valores da Tab. 4.3, percebe-se que nos pontos de mínimo, ambas as linhagens apresentam uma maior quantidade de cardiomiócitos com alto grau de alinhamento, quando comparado com os pontos de máximo e da moda. Em ambas as linhagens, o isoproterenol aumentou a porcentagem de cardiomiócitos com alto grau de alinhamento.

Os resultados da Curtose para os pontos de máximo e mínimo da $F_{\mathrm{T}}$ estão de acordo com o que foi apresentado na Fig.3.8, do Cap. 3. Nessa figura foi possível verificar 
que, conforme a $F_{\mathrm{T}}$ aumenta, a Curtose tende a subir, até pouco antes de atingir o ponto máximo da $F_{\mathrm{T}}$, para em seguida, cair para um valor mínimo quando a $F_{\mathrm{T}}$ é máxima.

\subsubsection{Orientação das forças de tração}

Com relação a orientação da $F_{\mathrm{R}}$, cabe ressaltar que para todos os cardiomiócitos analisados a $F_{\mathrm{R}}$ apresentou valores diferentes de zero. $\mathrm{O}$ que indica uma oscilação do centro de massa durante a pulsação dos cardiomiócitos. Para a análise da orientação da $F_{\mathrm{R}}$ foi gerado um histograma dos ângulos $\left(\theta_{F_{\mathrm{R}}}\right)$ dessa força, para cada cardiomiócito analisado. Após uma análise de correlação entre a distribuição dos ângulos no estado basal e estimulados com o isoproterenol, verificou-se que para aproximadamente $84 \%$ dos cardiomiócitos da linhagem WT as distribuições não apresentavam correlação. Já para a linhagem KO-CRP3 o mesmo ocorreu para 89\% dos cardiomiócitos analisados. A Fig.4.9 ilustra essa mudança na distribuição dos ângulos entre o estado basal e com isoproterenol para duas amostras, uma da linhagem WT e outra da linhagem KO-CRP3.
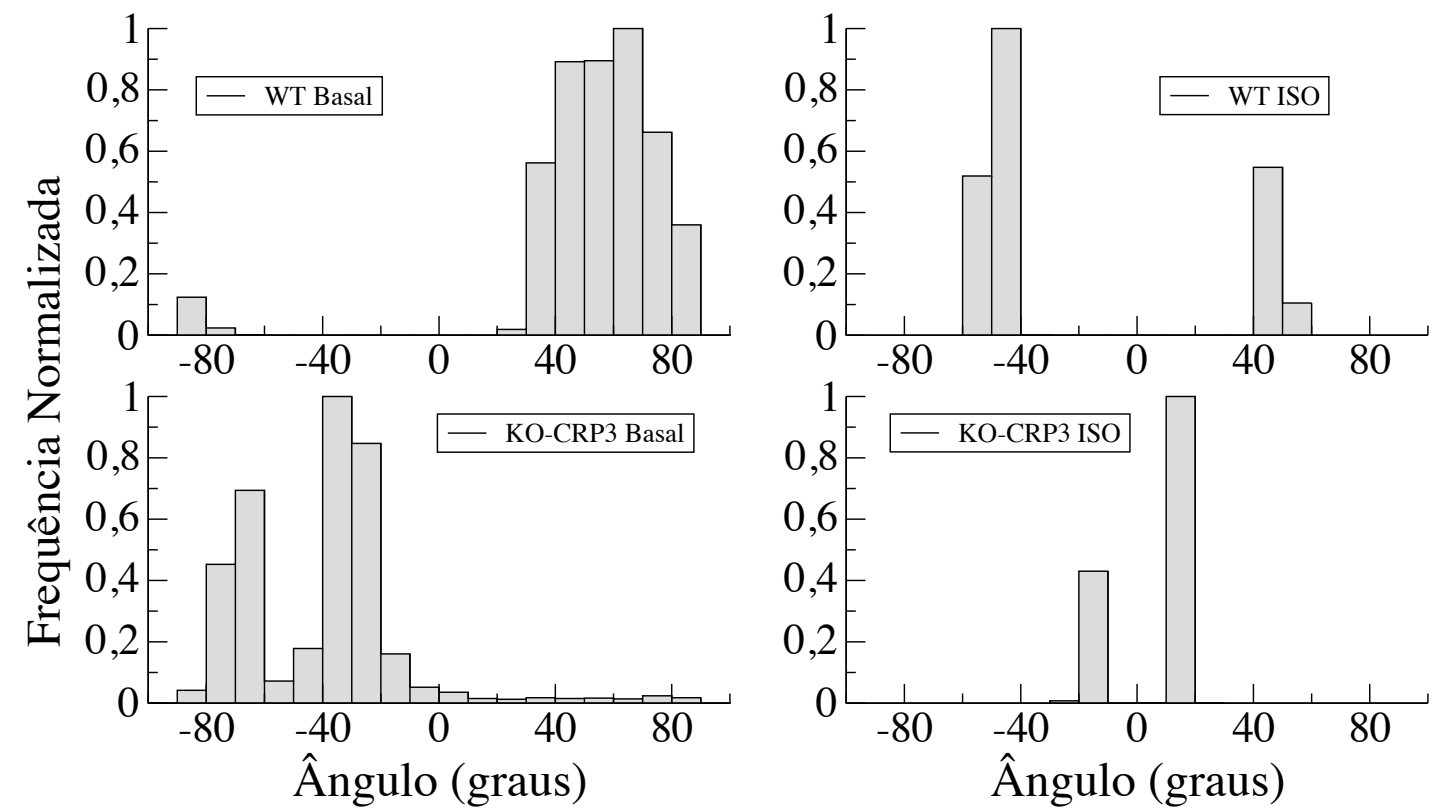

Figura 4.9: O gráfico apresenta o histograma dos ângulos da $F_{\mathrm{R}}$, no estado basal e após aplicação do isoproterenol, nas linhagens de cardiomiócitos analisadas.

Analisando os gráficos da Fig. 4.9 pode-se verificar que o isoproterenol mudou a orientação da $F_{\mathrm{R}}$. Dessa forma, a distribuição de forças no cardiomiócito pode mudar do estado basal para o estimulado com isoproterenol. Esse efeito pode ser visto na Fig.4.10, 
para o mesmo cardiomiócito da linhagem WT da Fig.4.9.
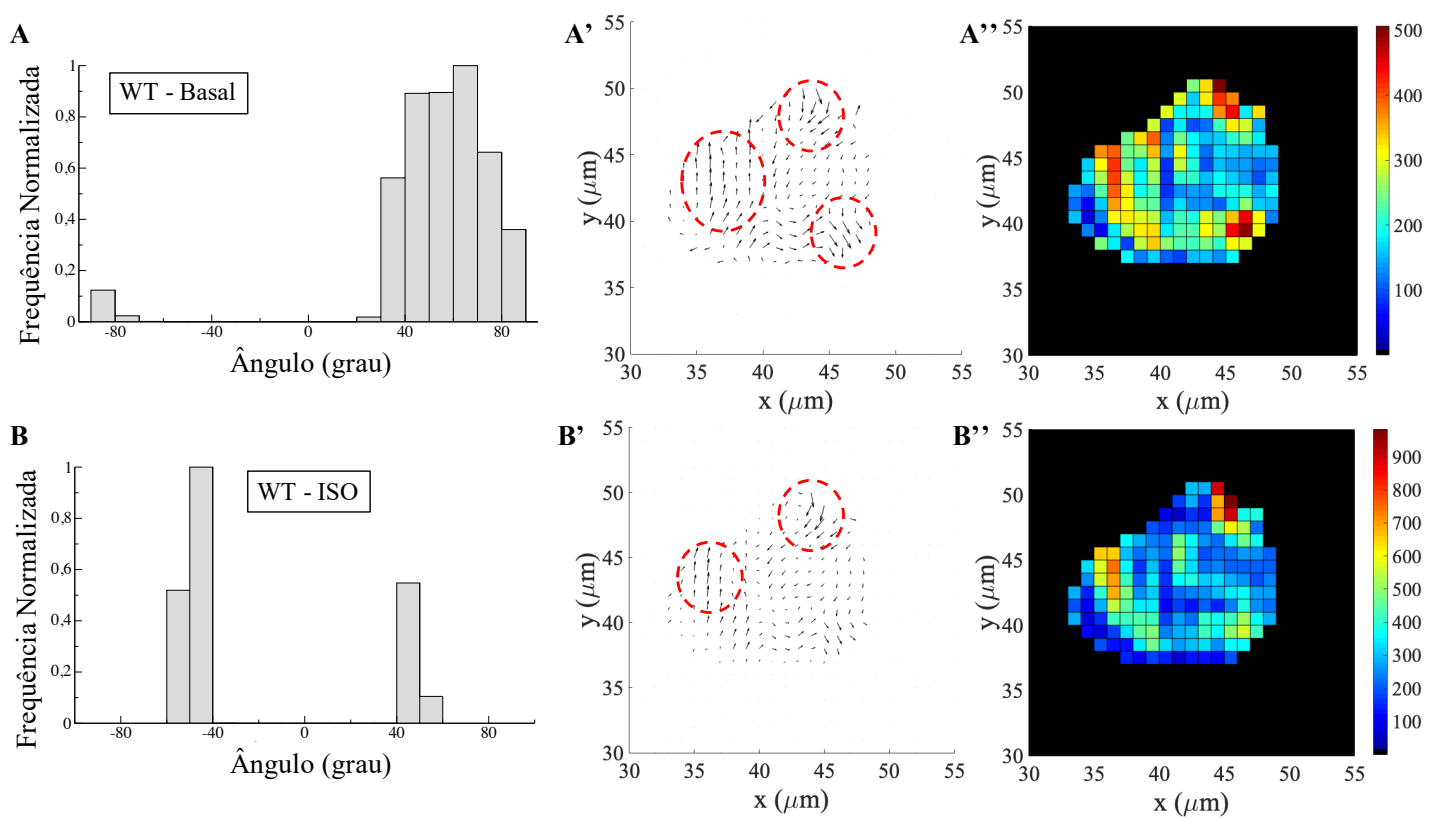

Figura 4.10: Em A temos o histograma da orientação das forças de tração de $\mathbf{A}^{\prime}$ no estado basal. Em $\mathbf{A}^{\prime}$ temos os vetores de força de tração média que estavam atuando no cardiomiócito da linhagem WT durante o ciclo de contração. Os círculos evidenciados em vermelho indicam as regiões da célula com maiores valores de forças de tração média. Em $\mathbf{A}^{\prime \prime}$ temos o mapa de forças onde, os valores de força de tração média aumentam do azul para o vermelho. As imagens $\mathbf{B}, \mathbf{B}^{\prime}$ e $\mathbf{B}^{\prime \prime}$ são equivalentes às imagens mostradas em $\mathbf{A}, \mathbf{A}^{\prime}$ e $\mathbf{A}^{\prime \prime}$, respectivamente, para o cardiomiócito estimulado com isoproterenol.

A Fig. 4.10 apresenta em A e $\mathbf{B}$ a distribuição dos ângulos da $F_{\mathrm{R}}$. Em $\mathbf{A}^{\prime}$ e $\mathbf{B}^{\prime}$ tem-se a orientação das forças de tração, representadas por um mapa vetorial das forças de tração médias onde, quanto maior o tamanho do vetor, maior é o valor da força naquele ponto. Em A" e B" está sendo representado um mapa de cores da intensidade da tração média para um cardiomiócito da linhagem WT no estado basal e estimulado com isoproterenol, respectivamente.

Pode-se verificar que no estado basal haviam três regiões onde as forças de tração médias eram maiores, conforme visto no mapa de forças em $\mathbf{A}^{\prime}$ e $\mathbf{A}^{\prime \prime}$. No entanto em B vê-se que a orientação muda com o isoproterenol. Diferente da configuração de $\mathbf{A}^{\prime}$, em $\mathbf{B}^{\prime}$ têm-se duas regiões com maiores forças de tração médias. Um comportamento semelhante ocorre para o cardiomiócito da linhagem KO-CRP3 conforme a Fig.4.9. A configuração das forças no estado basal e com isoproterenol para essa linhagem, pode ser vista na Fig.4.11. 

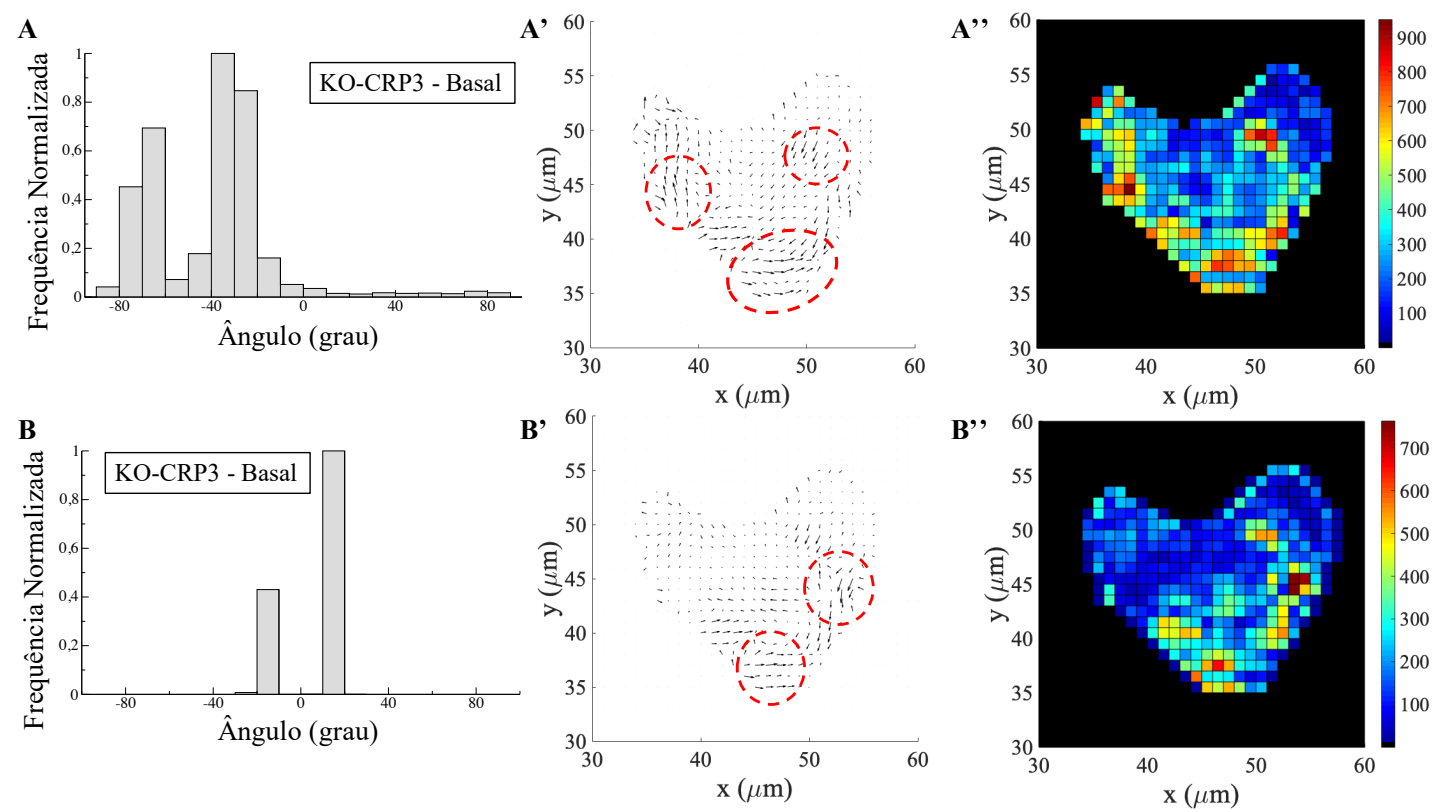

Figura 4.11: Em A temos o histograma da orientação das forças de tração de $\mathbf{A}^{\prime}$ no estado basal. Em $\mathbf{A}^{\prime}$ temos os vetores de força de tração média que estavam atuando no cardiomiócito da linhagem KO-CRP3 durante o ciclo de contração. Os círculos evidenciados em vermelho indicam as regiões da célula com maiores valores de forças de tração média. Em $\mathbf{A}^{\prime \prime}$ temos o mapa de forças onde, os valores de força de tração média aumentam do azul para o vermelho. As imagens $\mathbf{B}, \mathbf{B}^{\prime}$ e $\mathbf{B}^{\prime \prime}$ são equivalentes às imagens mostradas em $\mathbf{A}, \mathbf{A}^{\prime}$ e $\mathbf{A}^{\prime \prime}$, respectivamente, para o cardiomiócito estimulado com isoproterenol.

Nos dois exemplos de cardiomiócitos mostrados acima, vê-se que o isoproterenol afetou os polos de força da célula, mudando assim, a orientação das forças de tração exercidas pelo cardiomiócito durante o ciclo de contração. Esse fenômeno ocorreu em 26 cardiomiócitos da linhagem WT, entre o estado basal e o estimulado com isoproterenol, dos 31 analisados, representando aproximadamente $84 \%$ dos casos. Já para a linhagem KO-CRP3, essa alteração aconteceu em 24 dos 27 cardiomiócitos analisados, representando aproximadamente $89 \%$ dos casos.

\subsubsection{Potência de contração e relaxamento}

A análise da potência de contração e relaxamento foi realizada conforme descrito na sec.3.3. A Fig.3.10 (B) ilustra como foi obtida a potência de contração e relaxamento dos cardiomiócitos. Por esse gráfico foi possível extrair a mediana da curva referente a potência de contração e da curva referente a potência de relaxamento de cada cardiomiócito. Com isso, foi possível gerar um histograma desses valores para ambas as 
linhagens de cardiomiócitos analisados no estado basal e estimulado com isoproterenol.

Na Fig.4.12 é mostrado o histograma da potência de contração e de relaxamento para a linhagem WT no estado basal e estimulado com isoproterenol.
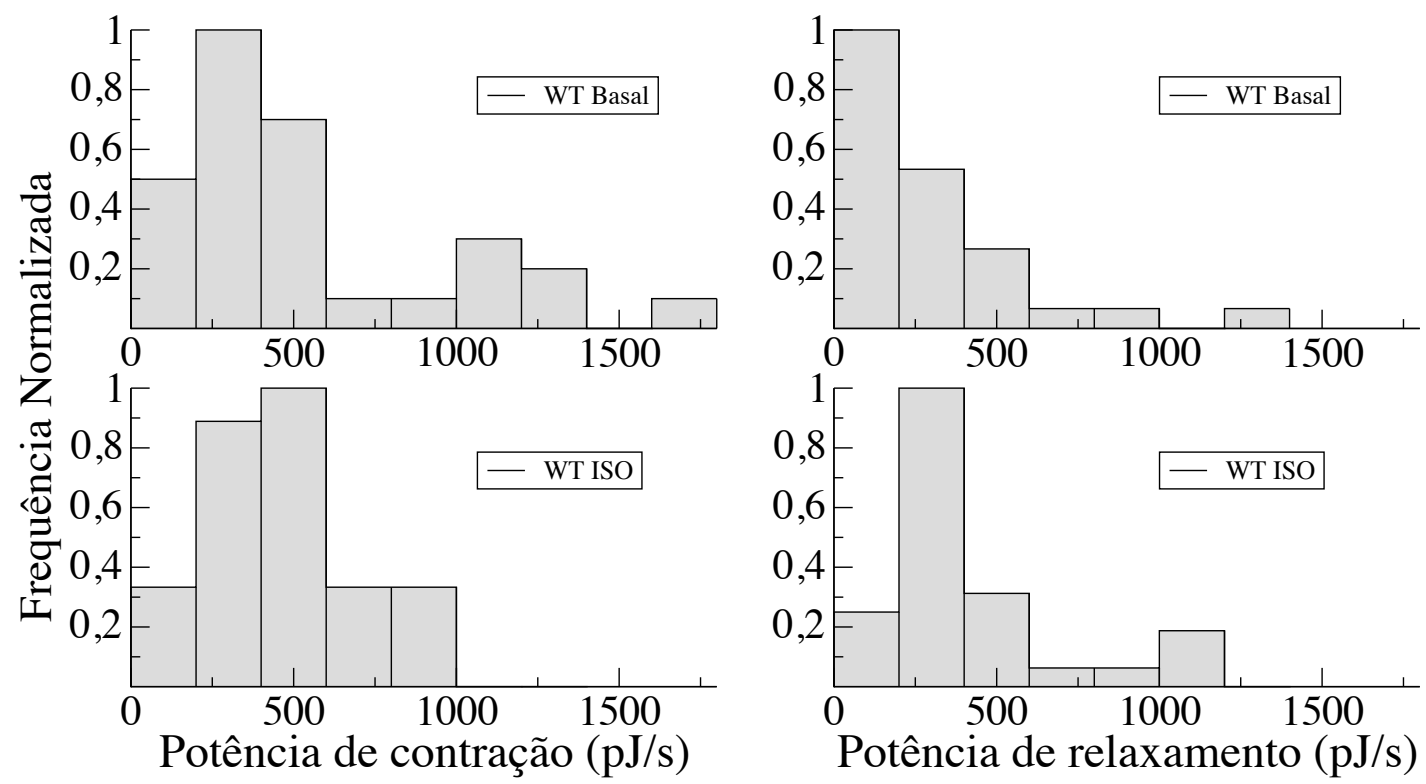

Figura 4.12: Essa figura apresenta o histograma da potência de contração e de relaxamento de cardiomiócitos da linhagem WT, no estado basal e estimulado com isoproterenol. Os histogramas superior e inferior do lado esquerdo se referem à potência de contração no estada basal e com isoproterenol, respectivamente. Os histogramas superior e inferior do lado direito se referem à potência de relaxamento no estada basal e com isoproterenol, respectivamente.

Vê-se que, os valores da potência de contração e relaxamento no estado basal variam próximo a zero até $1600 \mathrm{pJ} / \mathrm{s}$, enquanto que com isoproterenol essa faixa vai de zero até próximo de 1000 pJ/s. Como a distribuição dos valores de potência é assimétrica, foi ajustado um gráfico de boxplot da potência de contração e relaxamento para a linhagem WT, conforme a Fig.4.13. 


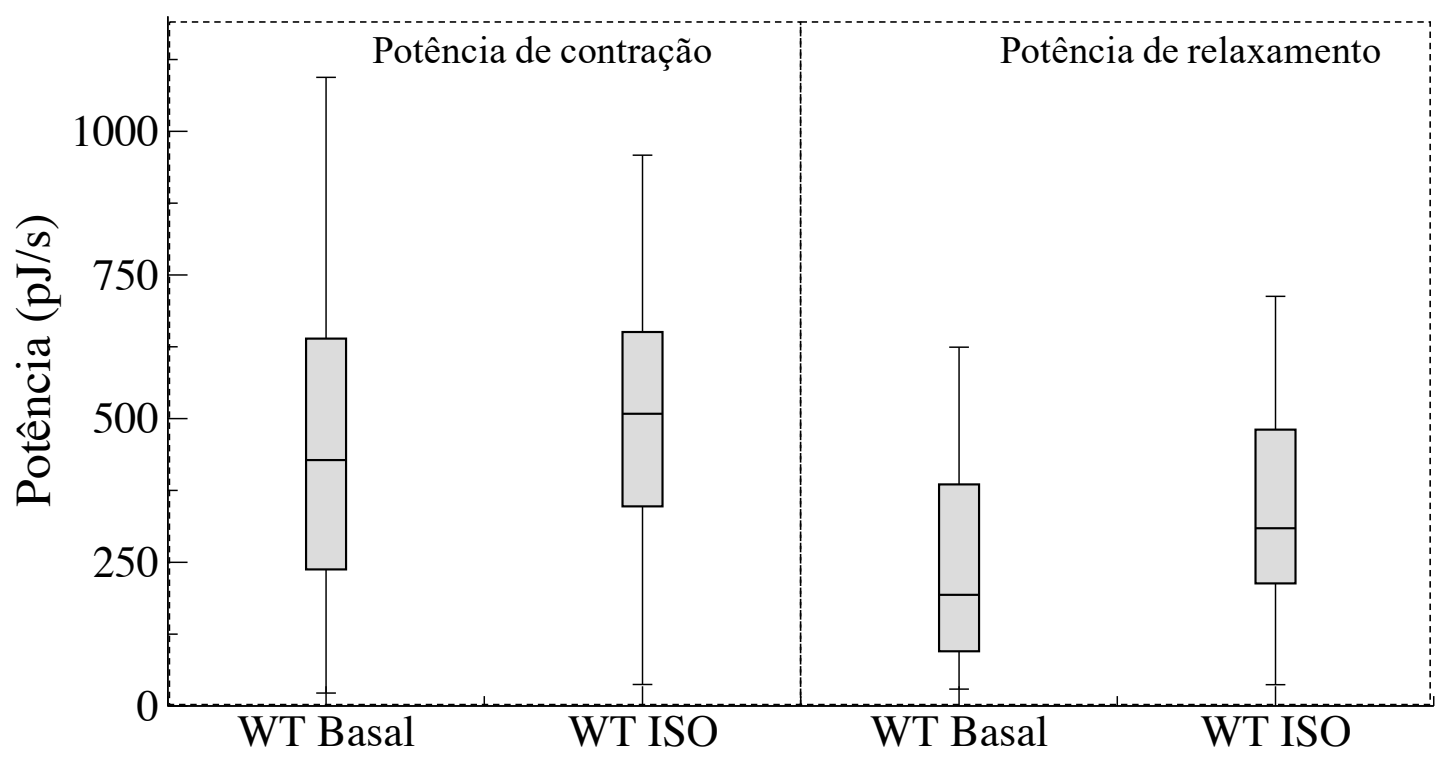

Figura 4.13: Essa figura apresenta o boxplot da potência de contração e de relaxamento de cardiomiócitos da linhagem WT, no estado basal e estimulado com isoproterenol.

Pela Fig.4.13 é possível verificar que, no geral, a potência de contração no estado basal apresenta uma mediana menor do que com isoproterenol e um tamanho de caixa, intervalo interquatil, maior. Já para a potência de relaxamento, o valor da mediana também aumenta com o isoproterenol, mas o intervalo interquatil apresenta pouca variação. Pelo tamanho da caixa do boxplot para cada estado, não é possível dizer que houve um aumento na potência de contração e relaxamento com o isoproterenol, por mais que a mediana aumente.

Também foi gerado um histograma e um gráfico de boxplot para a linhagem KOCRP3. Os histogramas da potência de contração e relaxamento no estado basal e com isoproterenol para essa linhagem, podem ser visto na Fig.4.14. 

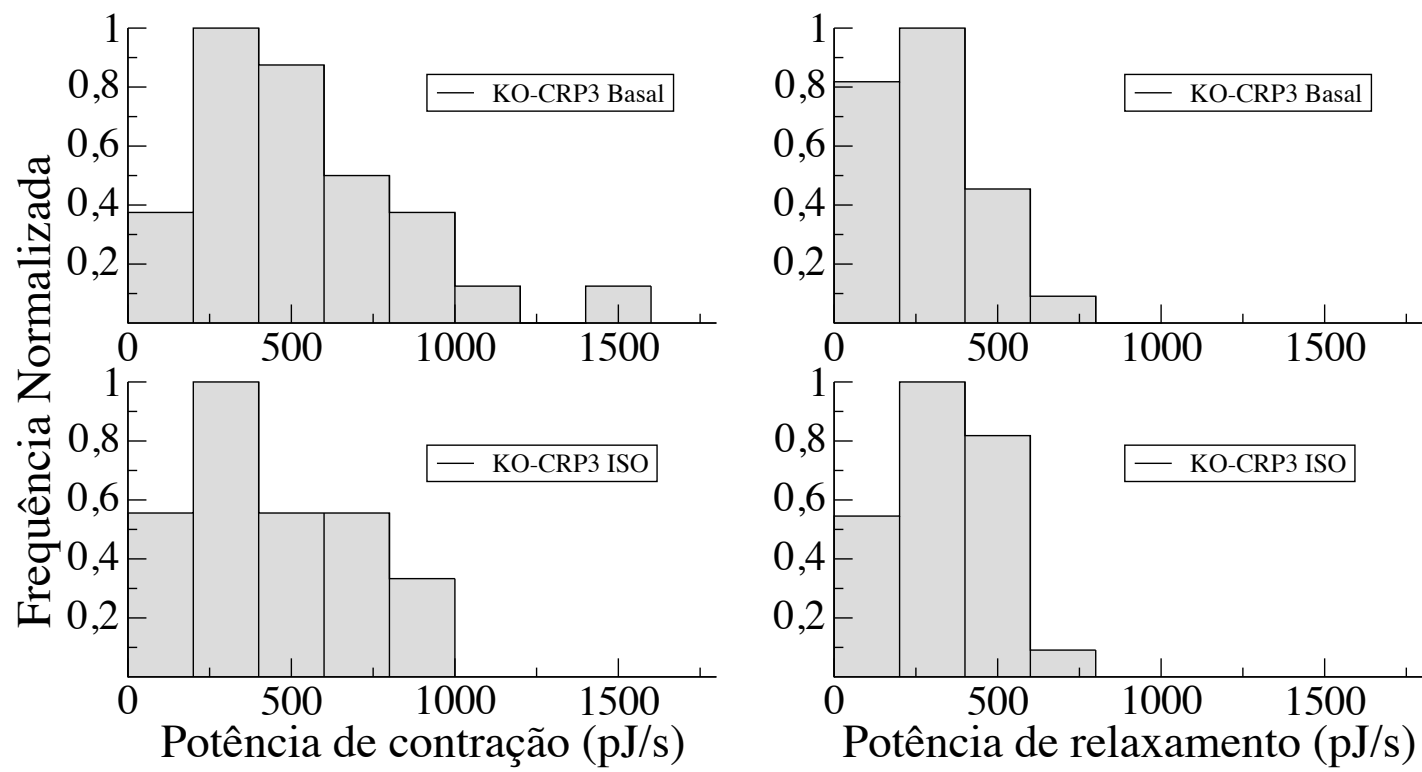

Figura 4.14: Essa figura apresenta o histograma da potência de contração e de relaxamento de cardiomiócitos da linhagem KO-CRP3 no estado basal e estimulado com isoproterenol. Os histogramas superior e inferior do lado esquerdo referem-se à potência de contração no estado basal e com isoproterenol, respectivamente. Os histogramas superior e inferior do lado direito se referem à potência de relaxamento no estado basal e com isoproterenol, respectivamente.

Comparando os histogramas da Fig. 4.14, para a linhagem KO-CRP3, com os da Fig.4.12, da linhagem WT, vê-se que a potência de contração entre as linhagens é muito semelhante no estado basal, e com distribuição entre valores praticamente iguais com isoproterenol. Já a potência de relaxamento apresenta uma distribuição com valores mais concentrados até próximo de $750 \mathrm{pJ} / \mathrm{s}$ na linhagem KO-CRP3 e variando até próximo de $1250 \mathrm{pJ} / \mathrm{s}$ para a linhagem WT, em ambos os estados.

Da mesma forma que para a linhagem WT, também foi ajustado um gráfico de boxplot com os valores de potência de contração e relaxamento para a linhagem KO-CRP3 no estado basal e com isoproterenol, conforme a Fig.4.15. 


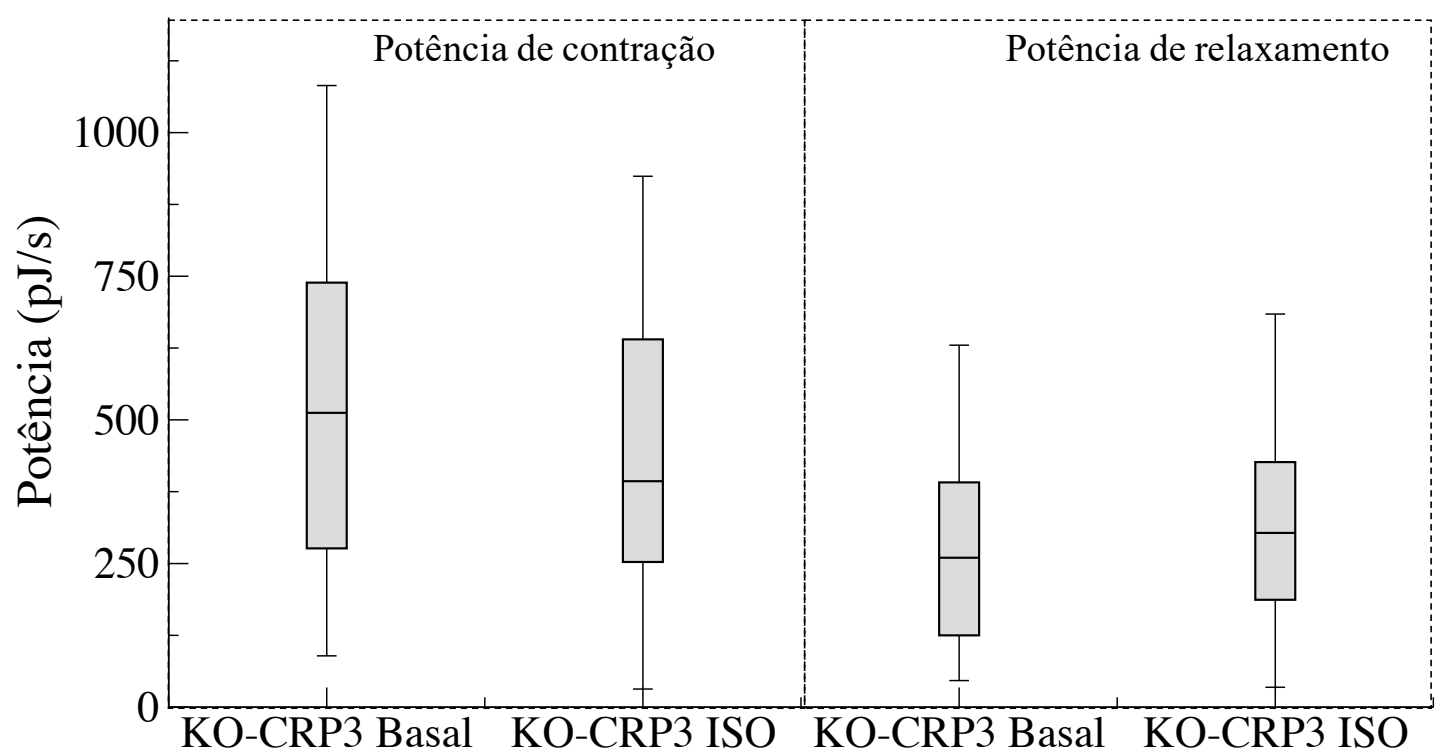

Figura 4.15: Essa figura apresenta o boxplot da potência de contração e de relaxamento de cardiomiócitos da linhagem KO-CRP3 no estado basal e estimulado com isoproterenol.

Pela Fig. 4.15 pode-se verificar que, da mesma forma que para a linhagem WT, o intervalo interquail entre as distribuições impossibilita afirmar que ocorre uma diferença significativa da potência de contração e relaxamento do estado basal para com o isoproterenol. No entanto, podemos perceber que para a linhagem KO-CRP3, a mediana da potência de contração diminui com o isoproterenol, o inverso do que acontece na linhagem WT. Já a potência de relaxamento apresenta um leve aumento no valor da mediana, semelhante ao que acontece com a linhagem WT.

Para uma melhor comparação entre os valores de potência entre as linhas, organizouse uma tabela com os valores da mediana da potência de contração e relaxamento entre as linhagens e a dispersão em torno da mediana, dado pelo intervalo interquatil. Pela Tab.4.4 é possível verificar que para a linhagem WT, tanto a mediana da potência de contração quanto de relaxamento aumentaram quando estimuladas com isoproterenol. Já para a linhagem KO-CRP3, a mediana da potência de contração diminui com o isoproterenol e a de relaxamento aumentou. No entanto não é possível afirmar que essa diferença dos valores médios entre os estados é significativa devido ao valor do intervalo interquartil ser alto. 
Tabela 4.4 - Mediana e intervalo interquartil da Potência de contração e relaxamento.

\begin{tabular}{|c|c|c|c|c|}
\hline & Potência de cc & ntração (pJ/s) & Potência de re & xamento $(\mathrm{pJ} / \mathrm{s})$ \\
\hline Linhagens & Basal & ISO & Basal & ISO \\
\hline WT & $427,8 \pm 401,7$ & $508,5 \pm 303,5$ & $193,4 \pm 290,4$ & $309,3 \pm 267,2$ \\
\hline KO-CRP3 & $512,3 \pm 462,4$ & $393,2 \pm 387,3$ & $260,0 \pm 266,2$ & $303,2 \pm 239,7$ \\
\hline
\end{tabular}

\subsubsection{Transformada de Fourier das forças de tração}

Prosseguindo as análises conforme mostrado na seção (3.4), será mostrado os resultados obtidos para a transformada de Fourier (TF) da $F_{\mathrm{T}}$ entre as linhagens de cardiomiócitos. Após ser realizada a $\mathrm{TF}$ da $F_{\mathrm{T}}$ para um determinado cardiomiócito foi identificado o valor de frequência com máxima amplitude, conforme apresentado na Fig. 3.11. Dessa forma foi possível gerar um histograma dos valores de frequência máxima para os cardiomiócitos da linhagem WT e KO-CRP3 no estado basal e estimulados com isoproterenol, conforme Fig. 3.11 .
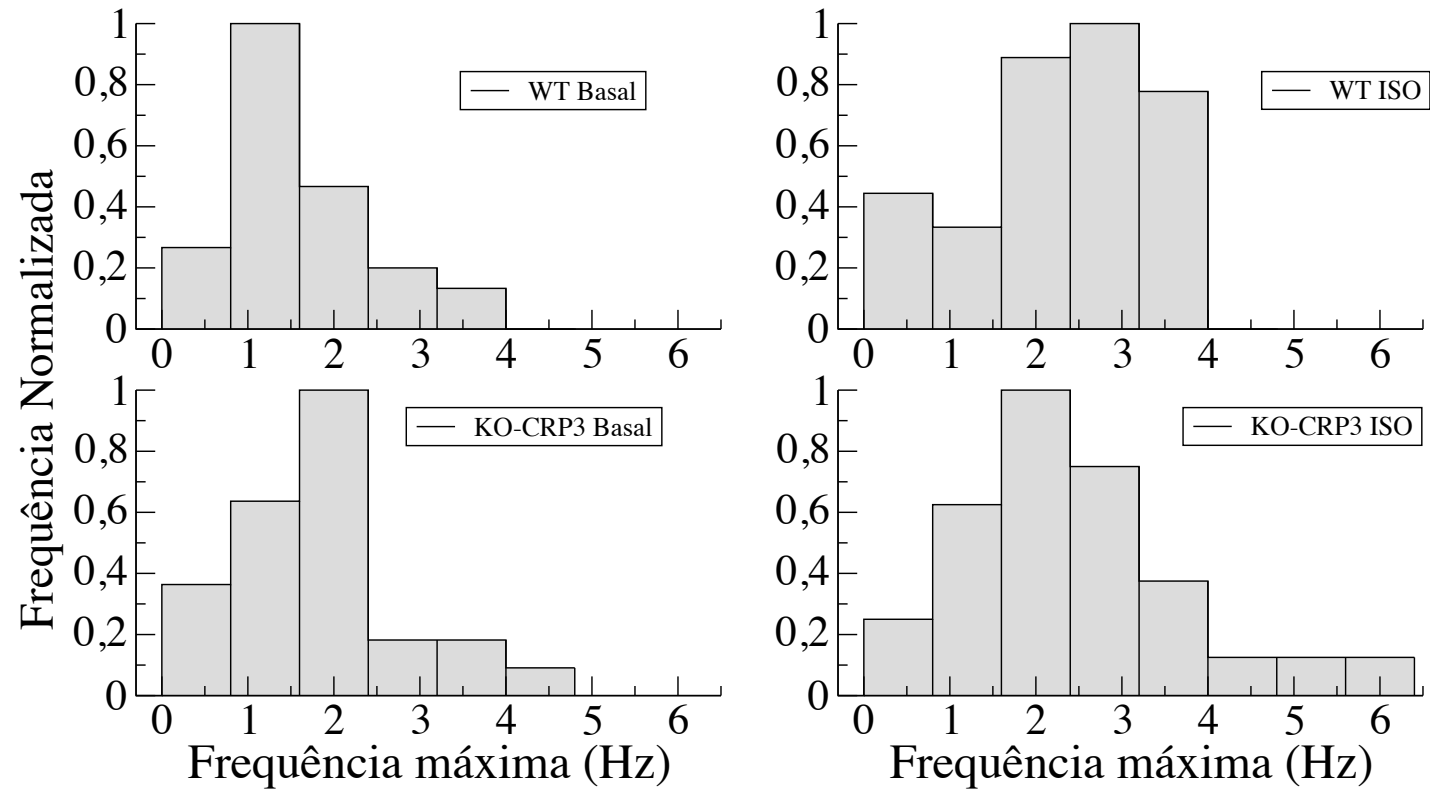

Figura 4.16: A figura apresenta o histograma da frequência máxima da $F_{\mathrm{T}}$ entre as linhagens WT e KO-CRP3 no estado basal e estimuladas com isoproterenol. Na parte superior têm-se os histogramas das frequências para a linhagem WT no estado basal (esquerda) e estimulado com isoproterenol (direita). Na parte inferior, têm-se os histogramas das frequências para a linhagem KO-CRP3, no estado basal (esquerda) e estimulado com isoproterenol (direita).

Os dados mostram que a distribuição de frequências muda do estado basal para com o isoproterenol, em ambas as linhagens. Para uma melhor comparação entre as 
linhagens, foi calculado a mediana e o intervalo interquaril da distribuição, no estado basal e estimuladas com isoproterenol, conforme Tab. 4.5 .

Tabela 4.5 - Mediana da distribuição da frequência máxima.

\begin{tabular}{l|cc} 
Linhagem & Basal $(\mathrm{Hz})$ & ISO $(\mathrm{Hz})$ \\
\hline WT & $1.55 \pm 0.8$ & $2.50 \pm 1.4$ \\
KO-CRP3 & $1.65 \pm 1.0$ & $2.40 \pm 1.7$
\end{tabular}

A Tab.4.5 mostra que a mediana frequência aumenta com isoproterenol, conforme o esperado, em ambas as linhagens. No entanto, como o desvio é relativamente alto, não é possível afirmar que o isoproterenol aumenta significativamente a frequência de todos os cardiomiócitos analisados.

Para complementar a análise da TF, foi gerado um gráfico da TF média para cada linhagem. Para isso, obteve-se a TF de cada cardiomiócito, conforme apresentado na sec. 3.4, e calculou-se a média da amplitude para cada valor de frequência obtida. Dessa forma é possível visualizar o comportamento médio da frequência de cada linhagem, no estado basal e com isoproterenol, conforme Fig.4.17.
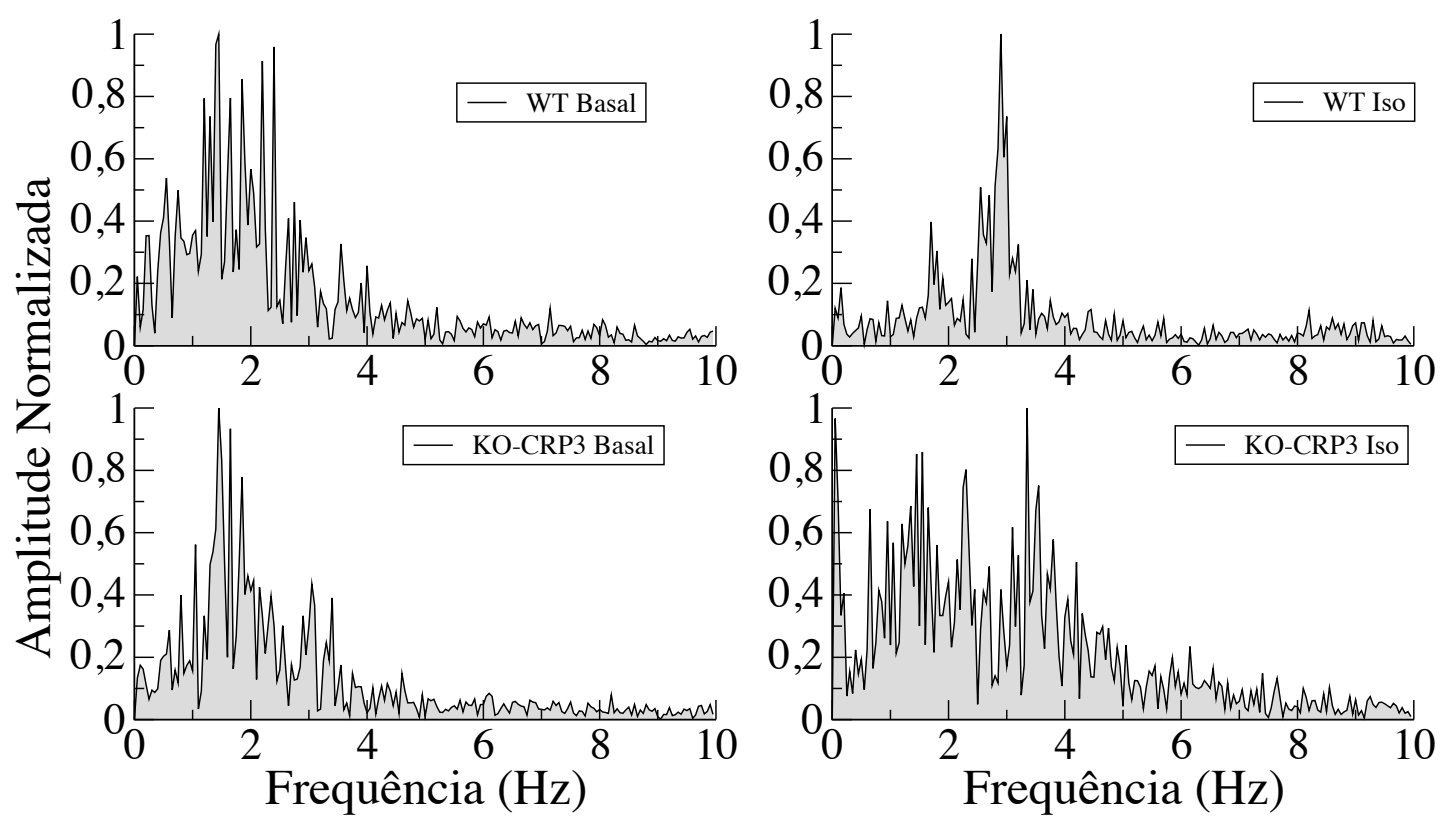

Figura 4.17: A figura apresenta a frequência média da $F_{\mathrm{T}}$ para cada linhagem de cardiomiócito no estado basal e estimulado com isoproterenol.

Pela Fig.4.17é possível verificar que, para linhagem WT a frequência com maior amplitude é maior e mais definida com o estímulo do isoproterenol. Esse estímulo 
diminuiu o ruído em torno do ponto de frequência máxima quando comparado com o estado basal. Já para a linhagem KO-CRP3 o ruído da frequência aumenta com o isoproterenol. A frequência com maior amplitude no estado basal continua alta com o isoproterenol, além de surgir um novo pico de amplitude para uma frequência mais alta. Assim, pode-se ver que o isoproterenol, em média, interfere na frequência de pulsação dos cardiomiócitos de forma diferente entre as linhagens. Aumentado a frequência com um menor ruído para a linhagem WT e aumentando amplitude de outros valores de frequência para a linhagem $\mathrm{KO}-\mathrm{CRP} 3$.

\subsubsection{Flutuações da amplitude e do período}

Por fim, serão apresentados os resultados obtidos com a análise da flutuação da amplitude e do período do sinal da $F_{\mathrm{T}}$ durante o ciclo de contração para os cardiomiócitos analisados. Com relação à flutuação da amplitude a Fig. 4.18 apresenta o boxplot dessa flutuação para a linhagem WT no estado basal e estimulada com isoproterenol.
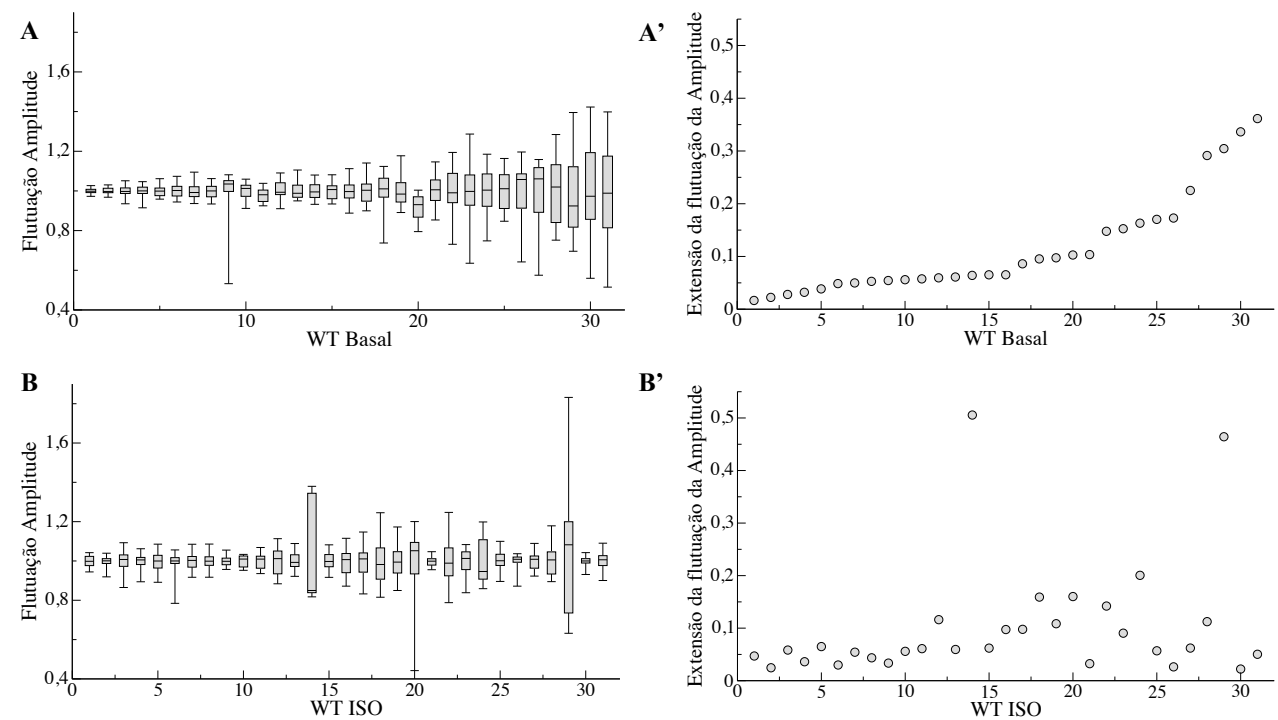

Figura 4.18: A: boxplot da flutuação da amplitude da $F_{\mathrm{T}}$ de cada cardiomiócito da linhagem WT no estado basal. $\mathbf{A}^{\prime}$ : Nesse gráfico, cada ponto representa o tamanho da caixa do boxplot da Fig.A, ou seja, quanto varia a flutuação da amplitude em torno da média. Nesses gráficos, os cardiomiócitos foram organizados em ordem crescente do tamanho da caixa do boxplot. B: boxplot da flutuação da amplitude da $F_{\mathrm{T}}$ dos cardiomiócitos correspondentes da Fig.A, estimulados com isoproterenol. B': Extensão da flutuação da amplitude em torno da média para os dados da Fig.B.

Na Fig.4.18, A e B é apresentado a flutuação da amplitude de cada cardiomiócito 
por um gráfico de boxplot, onde, quanto maior o tamanho da caixa do boxplot maior a flutuação da amplitude no cardiomiócito analisado. Em $\mathbf{A}^{\prime}$ e $\mathbf{B}^{\prime}$ tem-se o valor do tamanho da caixa de cada boxplot, dado pela diferença entre o terceiro e o primeiro quartil para a linhagem WT no estado basal e com isoproterenol, respectivamente. Pela Fig. 4.18. $\mathbf{A}^{\prime}$ e $\mathbf{B}^{\prime}$ pode-se verificar que no geral, quando estimulados com isoproterenol, a flutuação da amplitude dos cardiomiócitos da linhagem WT tende a diminuir.

O gráfico da Fig. 4.19 mostra o comportamento da flutuação da amplitude para a linhagem KO-CRP3. Pode-se verificar que geralmente a flutuação da amplitude para essa linhagem é similar entre o estado basal e com isoproterenol. Os valores da flutuação são próximos da linhagem WT com isoproterenol, e diferente do que ocorre para a linhagem WT, nessa linhagem, a flutuação da amplitude para alguns cardiomiócitos aumenta com o isoproterenol.
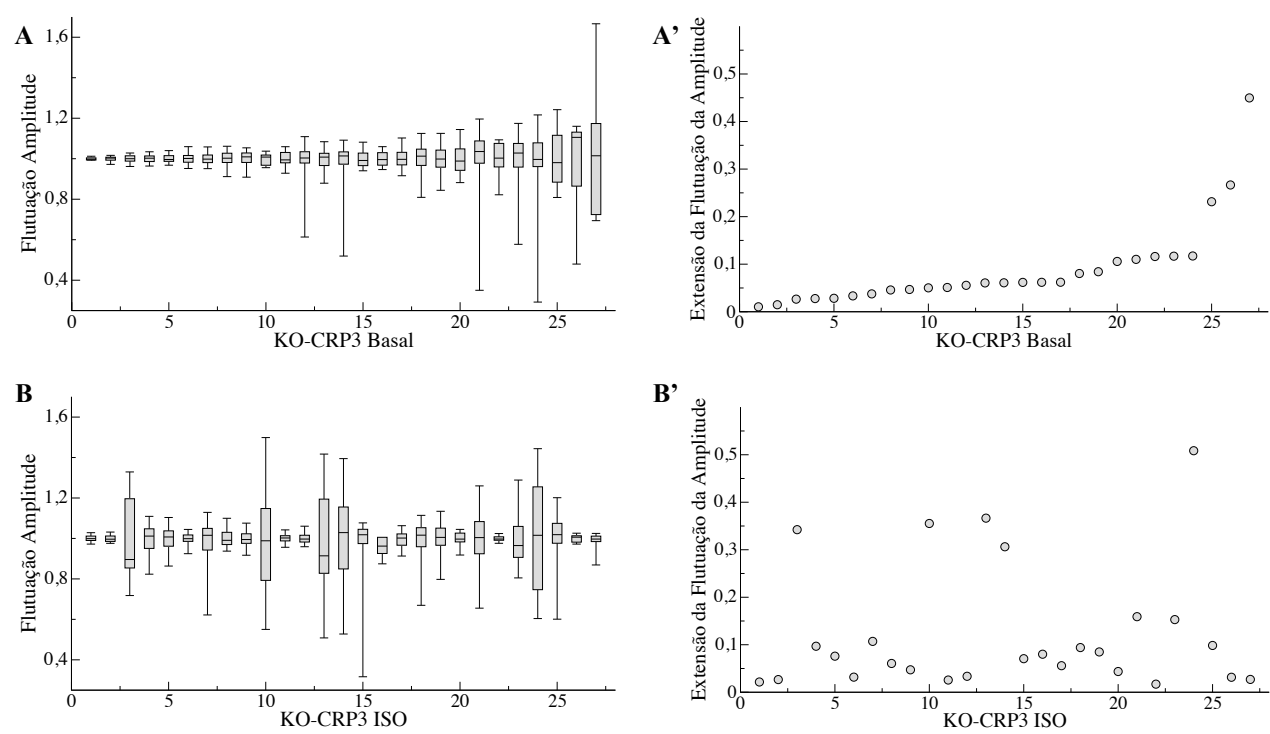

Figura 4.19: A: boxplot da flutuação da amplitude da $F_{\mathrm{T}}$ de cada cardiomiócito da linhagem KO-CRP3 no estado basal. A': Extensão da flutuação da amplitude em torno da média para os dados da Fig.A. Nesses gráficos, os cardiomiócitos foram organizados em ordem crescente do tamanho da caixa do boxplot. B: boxplot da flutuação da amplitude da $F_{\mathrm{T}}$ dos cardiomiócitos correspondentes da Fig.A, estimulados com isoproterenol. B': Extensão da flutuação da amplitude em torno da média para os dados da Fig.B.

Comparando os gráficos da Fig.4.18, da linhagem WT, e da Fig.4.19, da linhagem KO-CRP3, é possível verificar que a linhagem WT apresenta uma flutuação da amplitude maior no estado basal do que com isoproterenol, ou seja, o isoproterenol tende a diminuir a flutuação da amplitude para essa linhagem. Já a linhagem KO-CRP3 apresenta um 
comportamento mais regular da flutuação no estado basal e, quando estimulado com isoproterenol o comportamento é similar ao do WT no mesmo estado, porém, com mais cardiomiócitos aumentando a flutuação da amplitude.

Com relação à flutuação do período da $F_{\mathrm{T}}$ dos cardiomiócitos analisados, a Fig.4.20 apresenta a distribuição dessa flutuação para a linhagem WT no estado basal e com isoproterenol.
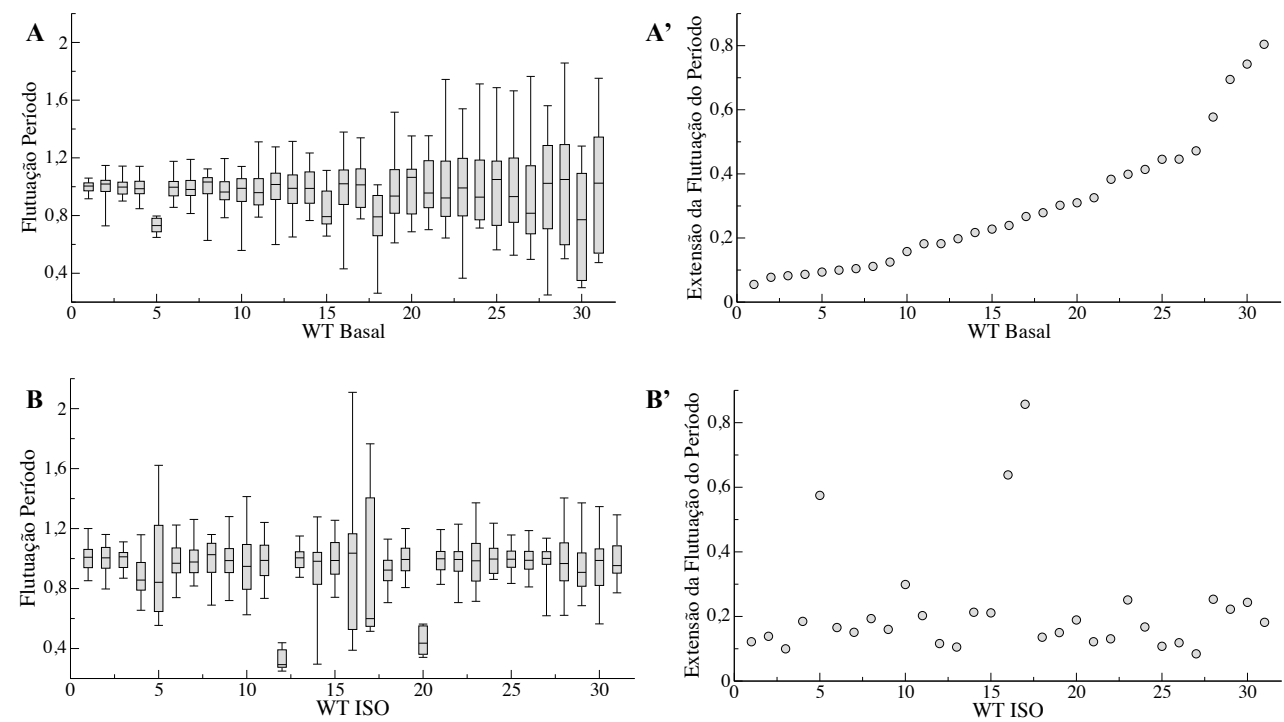

Figura 4.20: A: boxplot da flutuação do período da $F_{\mathrm{T}}$ de cada cardiomiócito da linhagem WT no estado basal. $\mathbf{A}^{\prime}$ : Extensão da flutuação da amplitude em torno da média para os dados da Fig.A. Nesses gráficos, os cardiomiócitos foram organizados em ordem crescente do tamanho da caixa do boxplot. B: boxplot da flutuação do período da $F_{\mathrm{T}}$ dos cardiomiócitos correspondentes da Fig.A, estimulados com isoproterenol. B': Extensão da flutuação da amplitude em torno da média para os dados da Fig.B.

O mesmo tipo de gráfico foi gerado para a linhagem KO-CRP3 no estado basal e com isoproterenol, conforme Fig.4.21. 

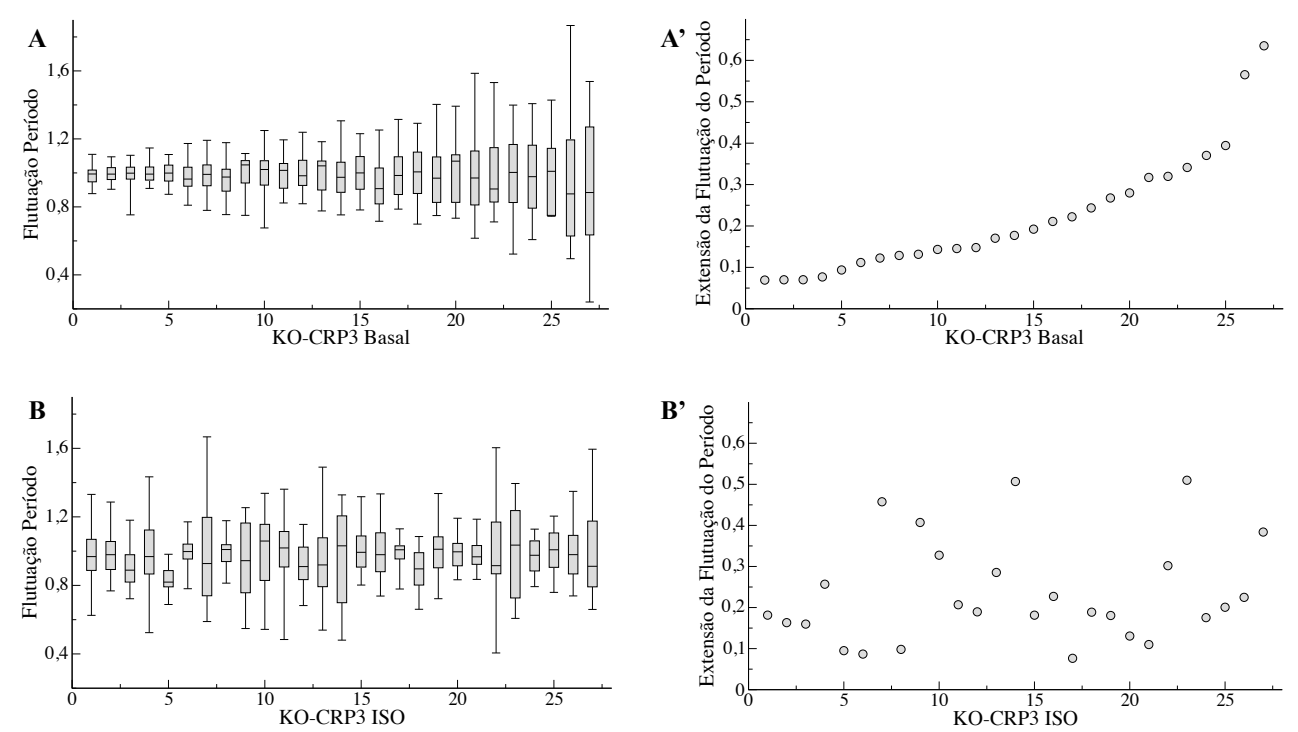

Figura 4.21: A: boxplot da flutuação do período da $F_{\mathrm{T}}$ de cada cardiomiócito da linhagem KO-CRP3 no estado basal. A': Extensão da flutuação da amplitude em torno da média para os dados da Fig.A. Nesses gráficos, os cardiomiócitos foram organizados em ordem crescente do tamanho da caixa do boxplot. B: boxplot da flutuação do período da $F_{\mathrm{T}}$ dos cardiomiócitos correspondentes da Fig.A, estimulados com isoproterenol. B': Extensão da flutuação da amplitude em torno da média para os dados da Fig.B.

Analisando os gráficos da flutuação do período de ambas as linhagens, é possível verificar que essa flutuação é maior que a da amplitude e parece ser comum entre os cardiomiócitos. Tanto no estado basal, quanto com isoproterenol, em ambas as linhagens os cardiomiócitos apresentaram uma extensão na flutuação do período maior que da flutuação da amplitude.

Comparando-se os pontos da Fig.4.20. $\quad \mathbf{A}^{\prime}$ e $\mathbf{B}^{\prime}$, vê-se que com o isoproterenol os cardiomiócitos da linhagem WT apresentaram uma flutuação menor e mais regular que no estado basal. No entanto, o mesmo não pode ser observado para a linhagem KO-CRP3, pelos dados mostrados na Fig.4.21. A' e $\mathbf{B}^{\prime}$. 


\subsection{Discussão}

Esses resultados mostram que a ferramenta computacional de análise aqui desenvolvida pode ser aplicada para o estudo de células cardíacas durante os ciclos de contração. Com essa ferramenta foi possível realizar uma análise mais refinada de determinados parâmetros e verificar diferenças entre as linhagens, que seria difícil de se obter analisando apenas o comportamento da $F_{\mathrm{T}}$. A metodologia desenvolvida para análise do alinhamento das forças de tração, dado pela Curtose, mostrou diferença entre as linhagens em três abordagens diferentes; utilizando como referência a Curtose da moda, a Curtose dos pontos de máximo da $F_{\mathrm{T}}$, assim como a Curtose dos pontos de mínimo da $F_{\mathrm{T}}$.

O intuito de desenvolver essas três abordagens para se analisar o alinhamento das forças de tração é refinar ao máximo a metodologia e poder realizar análises mais

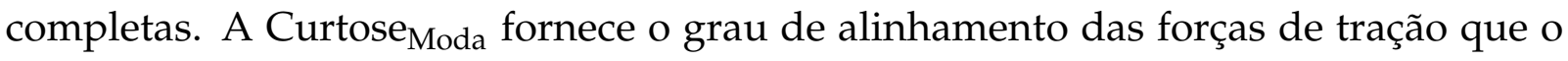
cardiomiócito apresentou durante a maior parte do tempo de aquisição dos dados. Já com os dados da Curtose dos pontos de máximo e mínimo da $F_{\mathrm{T}}$, é possível verificar em qual momento o cardiomiócito fica mais alinhado, se é durante a fase de contração ou de relaxamento.

Para a linhagem WT, os resultados apresentaram uma quantidade maior de cardiomiócitos com alto grau de alinhamento quando estimulados com isoproterenol, comparado ao estado basal nas três abordagens de Curtose analisadas. Já para a linhagem KO-CRP3 o mesmo só pode ser observado na Curtose dos pontos de mínimo. Para a Curtose dos pontos de máximo e da moda, a quantidade de cardiomiócitos com alto grau de alinhamento diminuiu do estado basal para aqueles estimulados com o isoproterenol, como pode ser visto na Tab.4.6 que reúne os dados apresentados nas tabelas (4.1), (4.2), (4.3) e (4.4), para uma melhor comparação entre os parâmetros.

Tabela 4.6 - Comparação entre os dados de alinhamento e potência.

\begin{tabular}{l|cccc} 
& \multicolumn{4}{|c}{ Linhagens } \\
\hline Parâmetros & WT Basal & WT ISO & KO-CRP3 Basal & KO-CRP3 ISO \\
\hline Curtose $_{\text {Moda }}$ & $\sim 26 \%$ & $\sim 45 \%$ & $\sim 37 \%$ & $\sim 33 \%$ \\
Curtose $_{\text {Máx }}$ & $\sim 35 \%$ & $\sim 42 \%$ & $\sim 33 \%$ & $\sim 30 \%$ \\
Curtose $_{\text {Min }}$ & $\sim 39 \%$ & $\sim 45 \%$ & $\sim 42 \%$ & $\sim 53 \%$
\end{tabular}


Essa possível diferença de alinhamento entre as linhagens pode estar relacionado com a presença da proteína CRP3 na linhagem WT e a sua ausência na linhagem KO-CRP3. Conforme descrito por alguns autores, a proteína CRP3 apresenta interação com as fibras de actina do citoesqueleto dos cardiomiócitos (Buyandelger et al., 2011; Campos et al. 2009). De uma forma geral, dependendo da situação ao qual a célula está submetida, ela organiza o seu citoesqueleto para suportar uma determinada força. Para isso, a célula utiliza a proteína CRP3 para fortalecer as conexões do citoesqueleto e prepará-lo para suportar a nova demanda que será exigida da célula (Buyandelger et al., 2011; Campos et al., 2009).

Dessa forma, uma das possibilidade é que, quando estimulados com o isoproterenol, os cardiomiócitos da linhagem WT conseguem recrutar as proteínas CPR3 necessárias para fortalecer as conexões do citoesqueleto, alinhando as forças de tração para suportar o aumento da demanda energética durante o ciclo de contração. No entanto, os cardiomiócitos da linhagem KO-CRP3 não conseguem realizar tal processo e quando são estimulados com o isoproterenol não conseguem fortalecer as conexões do citoesqueleto e desalinham as forças de tração, quando são mais exigidos durante a contração.

De certa forma, esses resultados podem colaborar no entendimento do alinhamento das forças e a sua relação com a proteína CRP3 para ajudar a estruturar o citoesqueleto de forma ordenada quando uma maior demanda energética é exigida dos cardiomiócitos. Os dados apresentados sugerem que existe uma relação entre essas variáveis, mas é insuficiente para descrever como isso ocorre. Seria necessário uma maior investigação para se relacionar o alinhamento das forças de tração com o do citoesqueleto, principalmente das fibras de actina, e como a proteína CPR3 pode afetar o fortalecimento das conexões do citoesqueleto durante o ciclo de contração dos cardiomiócitos.

Ainda com relação ao alinhamento, na Fig. 3.8 apresentada no Cap.3 foi possível verificar a relação entre diversos parâmetros durante o ciclo de contração, para um intervalo de tempo de 2,5 segundos. Na Fig.4.22 foi ajustado apenas o comportamento da $F_{\mathrm{T}}$ e da Curtose, para uma análise mais objetiva entre esses parâmetros. Nesse gráfico utilizou-se um cardiomiócito da linhagem KO-CRP3 como exemplo para realizar essa comparação. 


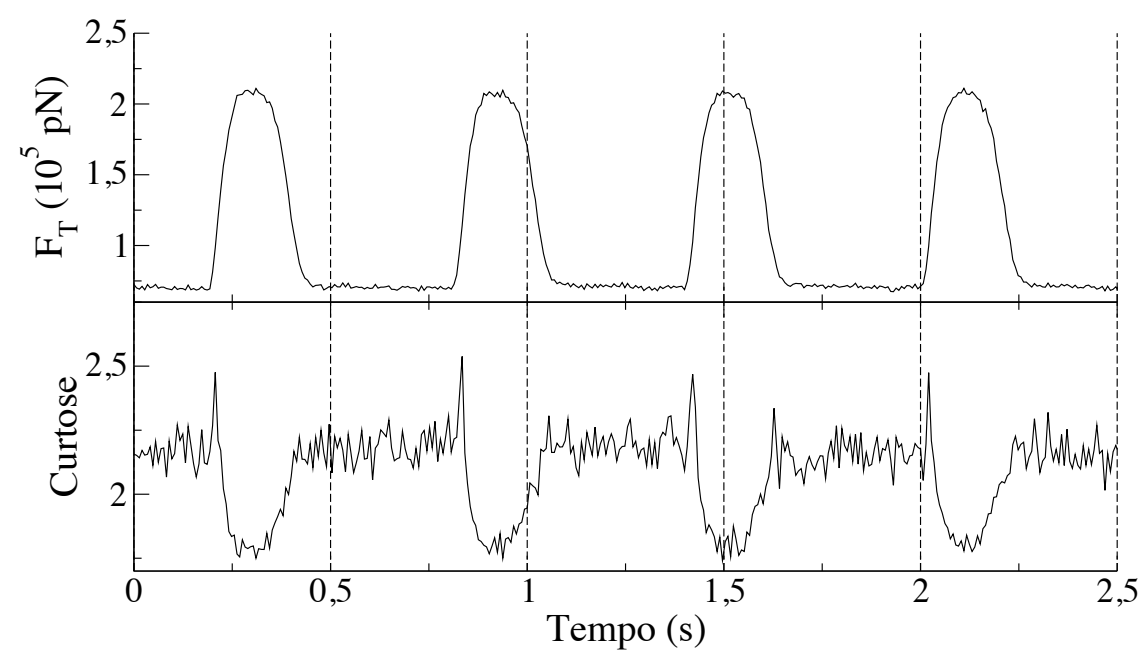

Figura 4.22: Nesse gráfico, mostram-se os comportamentos da $F_{\mathrm{T}}$, e da Curtose durante o intervalo de tempo de 2,5 segundos, para um cardiomiócito da linhagem KO-CRP3.

Analisando a Fig.4.22 é possível verificar que a Curtose tende a diminuir nos pontos de máximo da $F_{\mathrm{T}}$. Comparando a Curtose dos pontos de máximo e dos pontos de mínimo da Tab.4.6 pode-se ver que o percentual de cardiomiócitos com alto grau de alinhamento entre as linhagens WT e KO-CRP3 é maior nos pontos de mínimo do que nos pontos de máximo. No entanto, conforme a discussão anterior, como o cardiomiócito tende a fortalecer as ligações do citoesqueleto quando precisa realizar mais força e assim favorecer o alinhamento das forças de tração, o mais esperado seria de fato que o alinhamento aumentasse nos pontos de máximo da $F_{\mathrm{T}}$.

Para uma melhor análise desse resultado, foi ajustada uma figura com o comportamento da $F_{\mathrm{T}}$ e da Curtose para um curto intervalo de tempo, mas suficiente para capturar um ou mais ciclos de contração completos do cardiomiócito. Foi identificado o valor de Curtose máxima e mínima e gerado duas figuras para cada ponto. Uma figura do mapa de vetores com a orientação das forças de tração e outra, do mapa de cores da intensidade das forças de tração. Para isso, utilizou-se como exemplo um cardiomiócito da linhagem WT com formato mais arredondado e outro da linhagem KO-CRP3 com formato mais esticado.

A Fig.4.23 ilustra o comportamento apresentado para um cardiomiócito da linhagem WT no estado basal. Analisando essa figura, pode-se perceber que também para esse 
cardiomiócito o alinhamento tende a diminuir enquanto a $F_{\mathrm{T}}$ aumenta. Através do comportamento dos vetores e da intensidade das força de tração, vê-se que existem regiões em torno dos polos de maior força onde o alinhamento é maior. No entanto, para esse cardiomiócito como um todo, as forças de tração apresentam um baixo grau de alinhamento com valores de Curtose menores que 3.
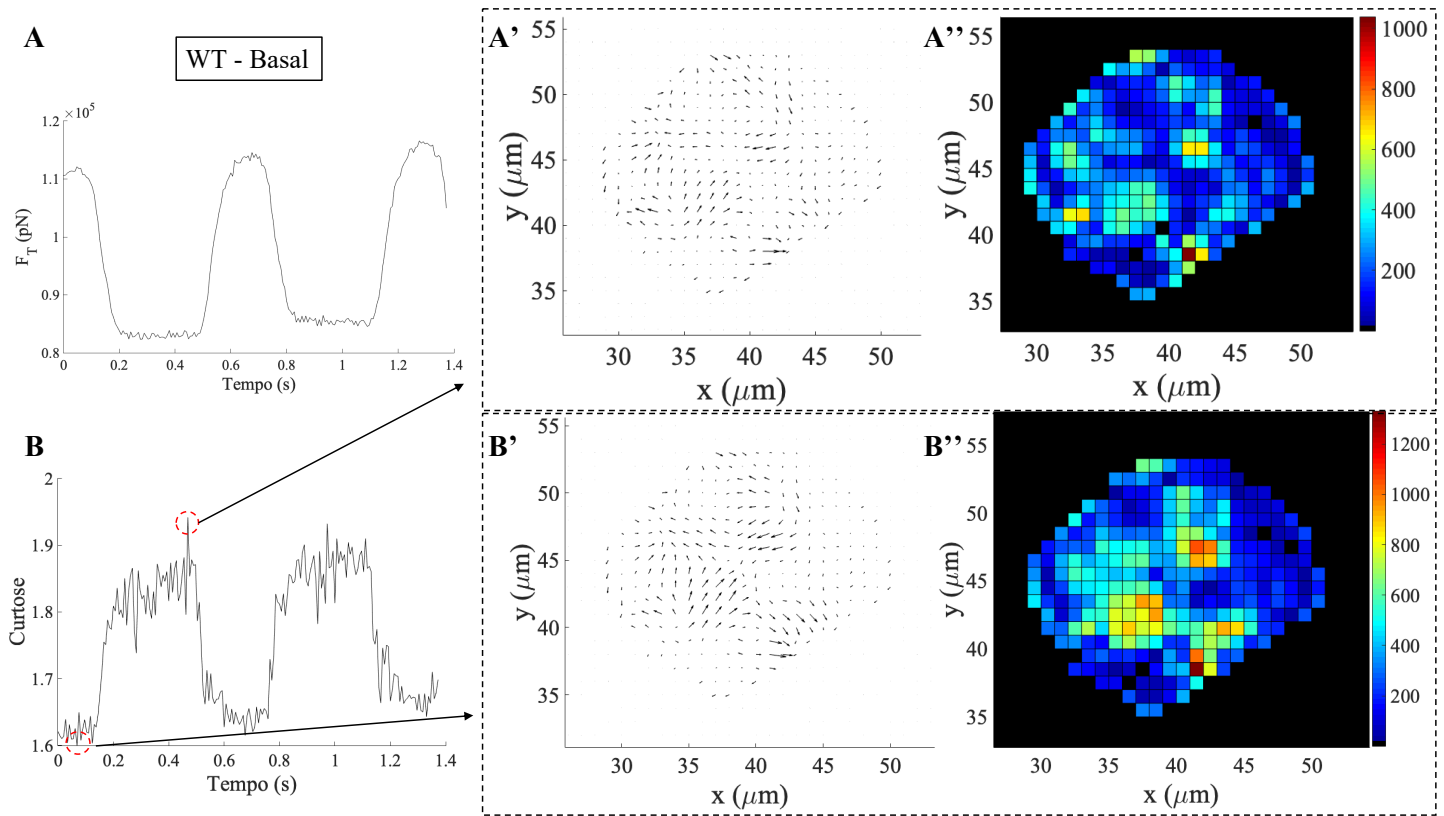

Figura 4.23: Em A: Comportamento da $F_{\mathrm{T}}$ durante um intervalo de tempo de 1,4 segundos para um cardiomiócito da linhagem WT no estado Basal. A': Vetores de força de tração que estavam atuando no cardiomiócito no ponto de Curtose máxima (indicado em B ). A": Mapa de forças onde, os valores de força de tração aumentam do azul para o vermelho. B: Comportamento da Curtose para um intervalo de tempo de 1,4 segundos para um cardiomiócito da linhagem WT no estado basal. Os círculos destacados em vermelho indicam os pontos de Curtose máxima e mínima. As figuras $\mathbf{B}^{\prime}$ e $\mathbf{B}^{\prime \prime}$ são equivalentes às mostradas em $\mathbf{A}^{\prime}$ e $\mathbf{A}^{\prime \prime}$, respectivamente, porém para o ponto de Curtose mínima.

A Fig.4.24 a seguir representa o comportamento do mesmo cardiomiócito da Fig.4.23, porém estimulado com isoproterenol. É interessante notar que, este cardiomiócito, quando estimulado com isoproterenol, muda o comportamento da Curtose com a $F_{\mathrm{T}}$. Agora a Curtose tende a acompanhar a $F_{\mathrm{T}}$ apresentando um valor maior nos pontos de $F_{\mathrm{T}}$ máximos. 

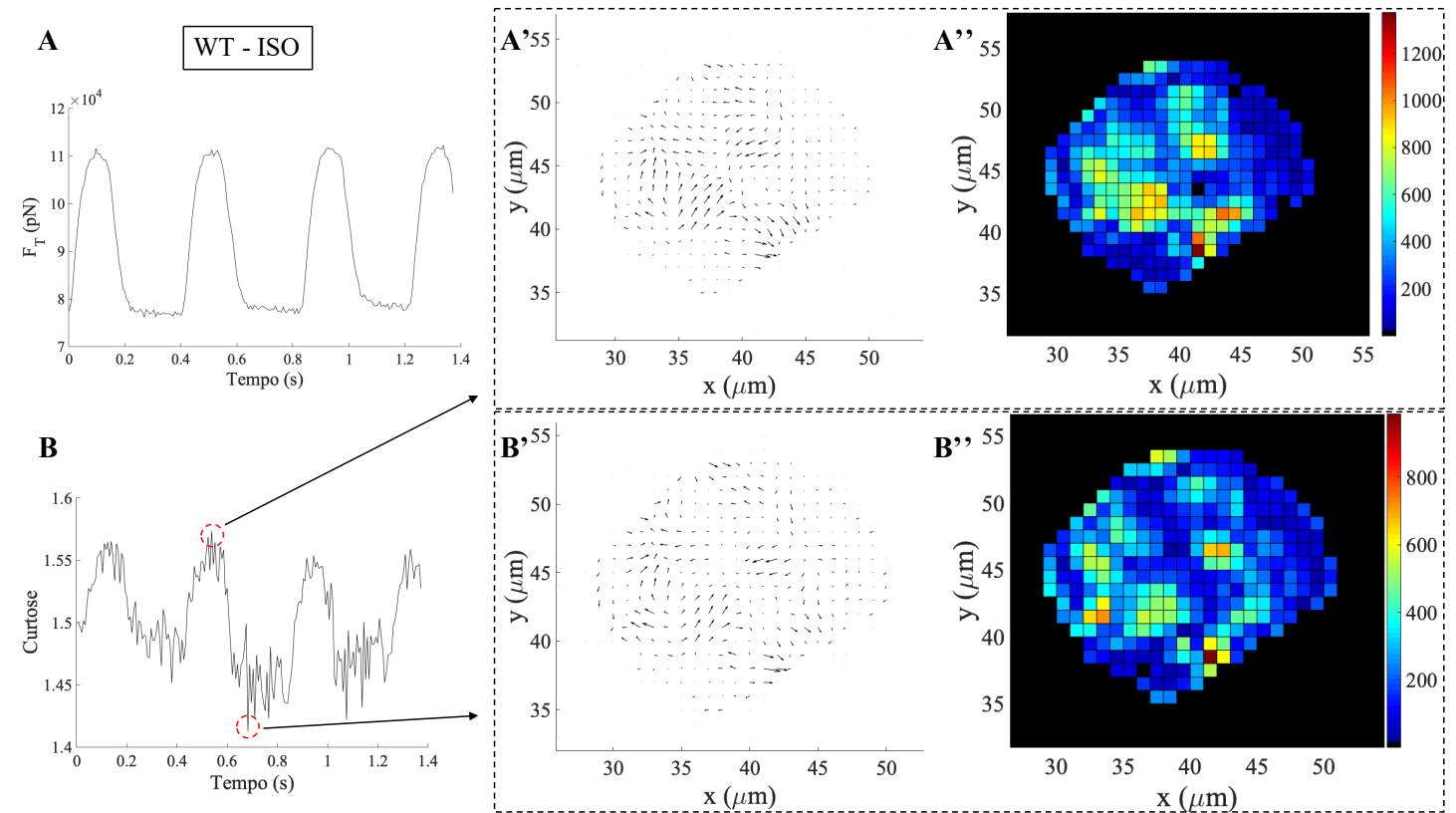

Figura 4.24: Em A: Comportamento da $F_{\mathrm{T}}$ durante um intervalo de tempo de 1,4 segundos para um cardiomiócito da linhagem WT estimulado com isoproterenol. A': Vetores de força de tração que estavam atuando no cardiomiócito no ponto de Curtose máxima (indicado em B ). A": Mapa de forças onde, os valores de força de tração aumentam do azul para o vermelho. B: Comportamento da Curtose para um intervalo de tempo de 1,4 segundos para um cardiomiócito da linhagem WT estimulado com isoproterenol. Os círculos destacados em vermelho indicam os pontos de Curtose máxima e mínima. As figuras B' e B" são equivalentes às mostradas em $\mathbf{A}^{\prime}$ e $\mathbf{A}^{\prime \prime}$, respectivamente, porém para o ponto de Curtose mínima.

Logo, não se pode afirmar que a Curtose sempre diminui nos pontos de força máxima. Tanto no estado basal como com isoproterenol o cardiomiócito apresentado nas figuras anteriores demonstra baixo grau de alinhamento, com valores de Curtose menores de 3. Analisando o formato do cardiomiócito, pode-se ver que ele é arredondado e que os polos de força apresentam uma diferença maior do ponto de Curtose máxima para o de Curtose mínima, quando estimulado com isoproterenol.

A Fig. 4.25 a seguir, segue o mesmo padrão das apresentadas anteriormente, porém para um cardiomiócito da linhagem KO-CRP3 com um formato mais esticado. Dessa forma, será possível avaliar o comportamento da Curtose em dois cardiomiócitos de formatos diferentes. 


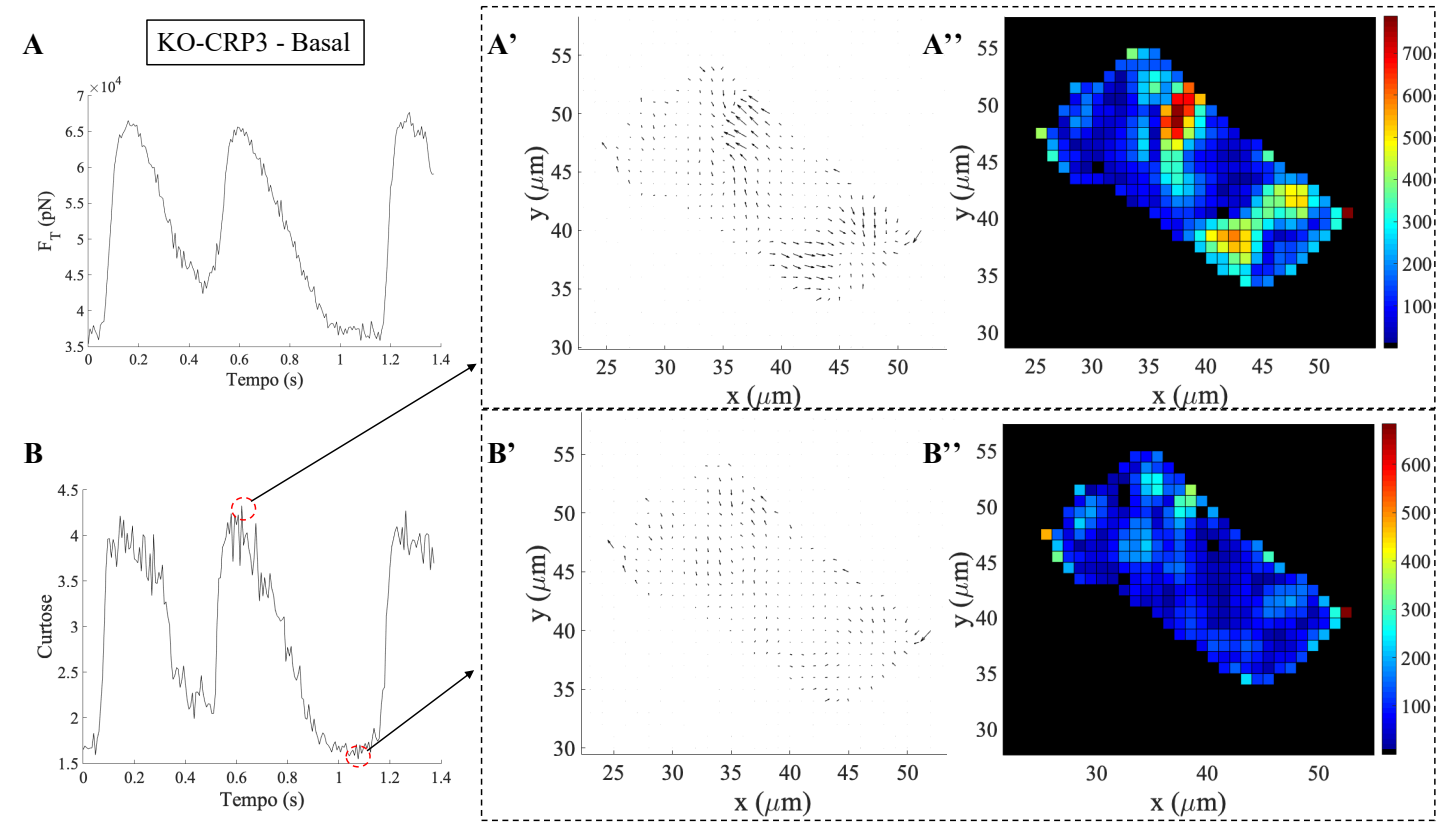

Figura 4.25: Em A: Comportamento da $F_{\mathrm{T}}$ durante um intervalo de tempo de 1,4 segundos para um cardiomiócito da linhagem KO-CRP3 no estado basal. A': Vetores de força de tração que estavam atuando no cardiomiócito no ponto de Curtose máxima (indicado em B ). A": Mapa de forças onde, os valores de força de tração aumentam do azul para o vermelho. B: Comportamento da Curtose para um intervalo de tempo de 1,4 segundos para um cardiomiócito da linhagem KO-CRP3 no estado basal. Os círculos destacados em vermelho indicam os pontos de Curtose máxima e mínima. As figuras $\mathbf{B}^{\prime}$ e $\mathbf{B}^{\prime \prime}$ são equivalentes às mostradas em $\mathbf{A}^{\prime}$ e $\mathbf{A}^{\prime \prime}$, respectivamente, porém para o ponto de Curtose mínima.

Pela Fig. 4.25 pode-se verificar que, novamente, a Curtose tende a aumentar nos pontos de $F_{\mathrm{T}}$ máximos. Nesses pontos, o cardiomiócito apresentou alto grau de alinhamento, com valores de Curtose maiores de 3. Pode-se verificar que esse alinhamento é maior nos polos de maior intensidade da força de tração. Além disso, esse cardiomiócito apresentou valores de Curtose maiores do que o da linhagem WT, que apresentava um formato mais arredondado.

A Fig.4.26 a seguir mostra o comportamento do mesmo cardiomiócito da linhagem KO-CRP3 estimulado com isoproterenol. Pode-se perceber que para esse cardiomiócito, o isoproterenol afetou significativamente o comportamento da Curtose. Vê-se que a Curtose tende a aumentar enquanto o cardiomiócito contrai e apresenta um valor mínimo nos pontos de $F_{\mathrm{T}}$ máximos. 

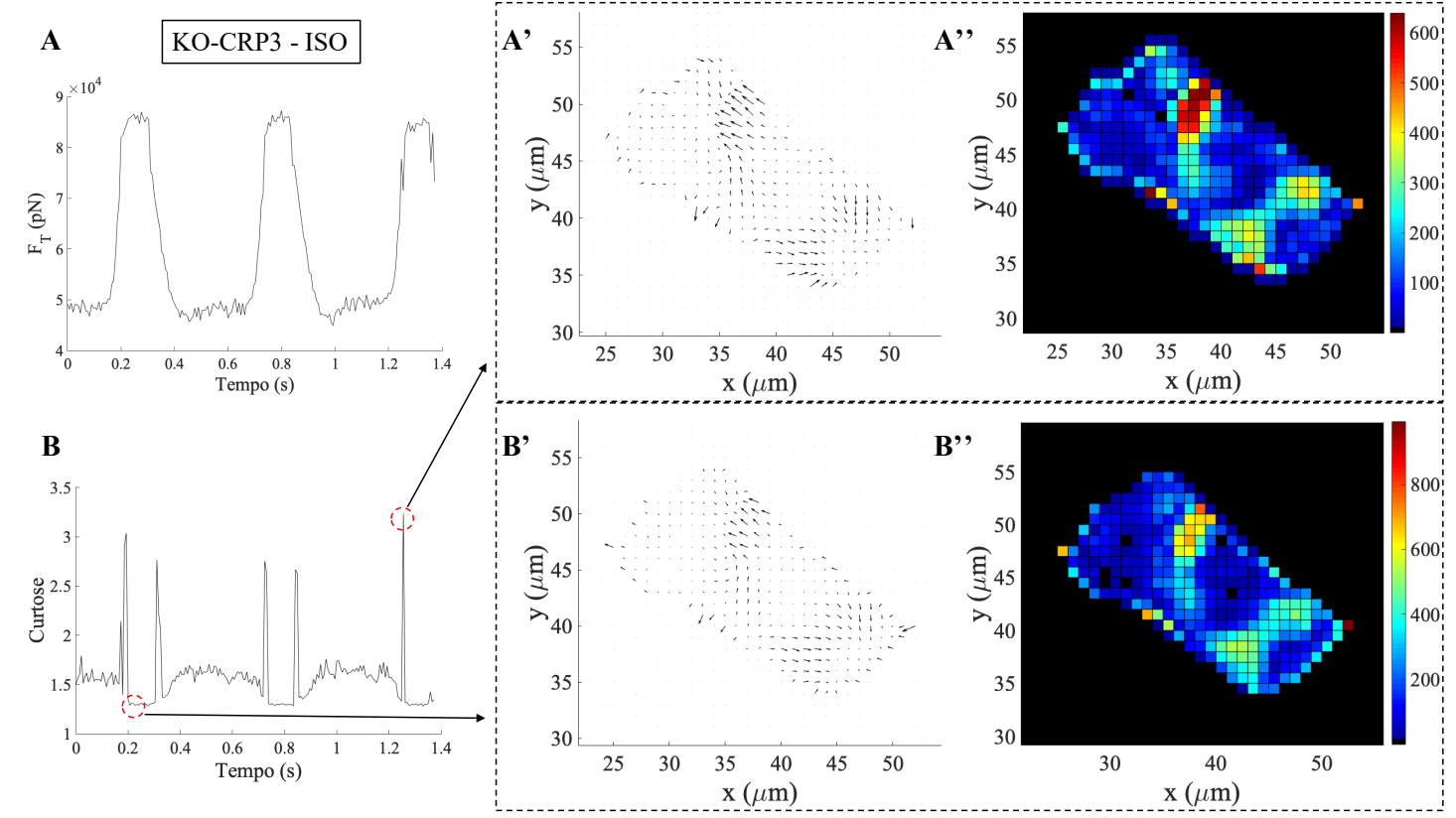

Figura 4.26: A: Comportamento da $F_{\mathrm{T}}$ durante um intervalo de tempo de 1,4 segundos para um cardiomiócito da linhagem KO-CRP3 estimulado com isoproterenol. $\mathbf{A}^{\prime}$ : Vetores de força de tração que estavam atuando no cardiomiócito no ponto de Curtose máxima (indicado em B ). A": Mapa de forças onde, os valores de força de tração aumentam do azul para o vermelho. B: Comportamento da Curtose para um intervalo de tempo de 1,4 segundos para um cardiomiócito da linhagem KO-CRP3 estimulado com isoproterenol. Os círculos destacados em vermelho indicam os pontos de Curtose máxima e mínima. As figuras B' e B" são equivalentes às mostradas em $\mathbf{A}^{\prime}$ e $\mathbf{A}^{\prime \prime}$, respectivamente, porém para o ponto de Curtose mínima.

Pode-se verificar que os polos da intensidade da força de tração são significativamente diferentes nos pontos de Curtose mínima entre os estado basal e com isoproterenol. Mesmo com essa mudança de comportamento o cardiomiócito apresentou um maior grau de alinhamento nos polos de maior intensidade das forças de tração, com valores de Curtose em torno de 3.

Com essas análises é possível verificar que o alinhamento pode depender tanto da mobilização de proteínas CRP3 para fortalecer as ligações do citoesqueleto e alinhar as forças de tração, assim como do formato da célula. Este fato sugere uma possível correlação entre os aspectos morfológicos e mecânicos das células, provavelmente induzida pela modulação da atividade desta proteína.

Em um trabalho recente, Alexandre J.S Ribeiro et. al. mostrou que o formato de cardiomiócitos isolados influencia o alinhamento de miofibrilas, que são organelas tubulares responsáveis pela contratilidade celular (Ribeiro et al. 2015). Nesse trabalho, 
um dos resultados obtidos pelos autores foi que, um cardiomiócito com formato mais alongado tende a ter um maior alinhamento das miofibrilas do que um cardiomiócito com formato mais arredondado (Ribeiro et al., 2015).

Por mais que neste trabalho não esteja analisando o alinhamento das miofibrilas e sim das forças de tração, pode ser que exista uma relação semelhante entre o formato do cardiomiócito e o alinhamento das forças de tração, visto que o mesmo ocorre para os cardiomiócitos das figuras acima. Existem trabalhos em que o estudo da dinâmica é realizado com células isoladas que se aderem em um gel com formato definido, conhecido como micropatterned (Balaban et al., 2001; Kim et al., 2011; Ye et al., 2014). Essa técnica, se acoplada com a técnica de TFM, pode auxiliar no melhor entendimento da relação entre o alinhamento das forças de tração e o formato dos cardiomiócitos. Atualmente, o nosso grupo de pesquisa está implementando essa técnica em nosso laboratório e espera-se que futuramente possa se obter dados suficientes para realizar esse tipo de análise.

As análises referentes à frequência de pulsação dos cardiomiócitos, obtidas pela TF do sinal da $F_{\mathrm{T}}$, mostraram que na média o isoproterenol aumentou a frequência em ambas as linhagens. Analisando apenas esse parâmetro não é possível identificar diferenças na frequência de pulsação entre as linhagens. No entanto, com a curva da TF média da $F_{\mathrm{T}}$ de cada uma das linhagens, no estado basal e com isoproterenol, é possível observar um comportamento diferente entre as linhagens de cardiomiócitos.

Na linhagem WT, o isoproterenol além de aumentar a frequência, diminuiu o ruído gerado pelas frequências com amplitudes mais baixas. Em alguns experimentos foi possível notar que, para um mesmo cardiomiócito, certa região pulsava com uma frequência diferente de outra região. Isso pode ser um dos fatores que contribuem para que no estado basal a faixa de frequência com alta amplitude seja maior. Outro fator possível é de que, nesse estado, os cardiomiócitos no geral não têm uma frequência de pulsação bem definida. Já com o isoproterenol, a faixa de frequência com alta amplitude é menor, o que pode ser um indício de que a maioria dos cardiomiócitos passaram a pulsar com uma frequência maior e mais definida.

Quando comparada com a linhagem WT, é possível verificar que o isoproterenol não teve o mesmo efeito na linhagem KO-CRP3. Para essa linhagem, o estímulo do isoproterenol apenas ampliou a faixa de frequência com alta amplitude. O mesmo valor de frequência predominante do estado basal continua com o isoproterenol, além de que, 
outras frequências de menor e maior valor aumentaram sua amplitude.

Esse comportamento da frequência de pulsação média das linhagens pode estar influenciando na flutuação do período e da amplitude do sinal da $F_{\mathrm{T}}$ analisadas. $\mathrm{O}$ gráfico da Fig.4.27 abaixo, ilustra a curva da frequência média da linhagem WT no estado basal e com isoproterenol, agrupada com a extensão da flutuação do período e da amplitude, para possibilitar uma análise mais clara desses parâmetros.
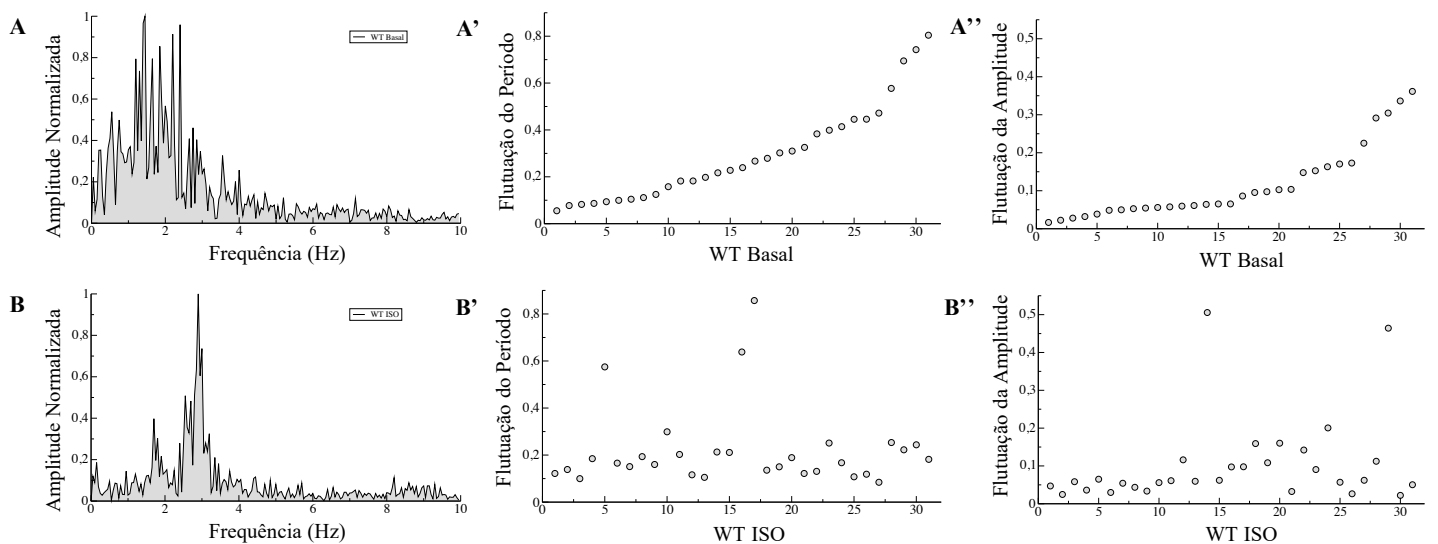

Figura 4.27: A: Comportamento da frequência média da $F_{\mathrm{T}}$ da linhagem WT no estado basal. A': Variação da flutuação do período em torno da média dos cardiomiócitos da linhagem WT no estado basal. A": Variação da flutuação da amplitude em torno da média dos cardiomiócitos da linhagem WT no estado basal. B: Comportamento da frequência média da $F_{\mathrm{T}}$ da linhagem WT estimulado com o isoproterenol. B': Variação da flutuação do período em torno da média dos cardiomiócitos da linhagem WT estimulados com isoproterenol. B" Variação da flutuação da amplitude em torno da média dos cardiomiócitos da linhagem WT estimulados com isoproterenol.

Pela figura é possível perceber que a presença de um pico de frequência melhor definido bem como a diminuição da flutuação do período e da amplitude para a maioria dos cardiomiócitos da linhagem WT, quando estimulados com o isoproterenol. Para essa linhagem o isoproterenol agiu de forma mais significativa do que para a KO-CRP3, e a variação da flutuação do período e da amplitude da curva da $F_{\mathrm{T}}$ podem estar indicando que os cardiomiócitos estão pulsando de forma mais regular e sincronizada quando estimulados com isoproterenol. A Fig. 4.28 apresenta a curva da frequência média para a linhagem KO-CRP3 no estado basal e com isoproterenol, agrupada com a extensão da flutuação do período e da amplitude. 

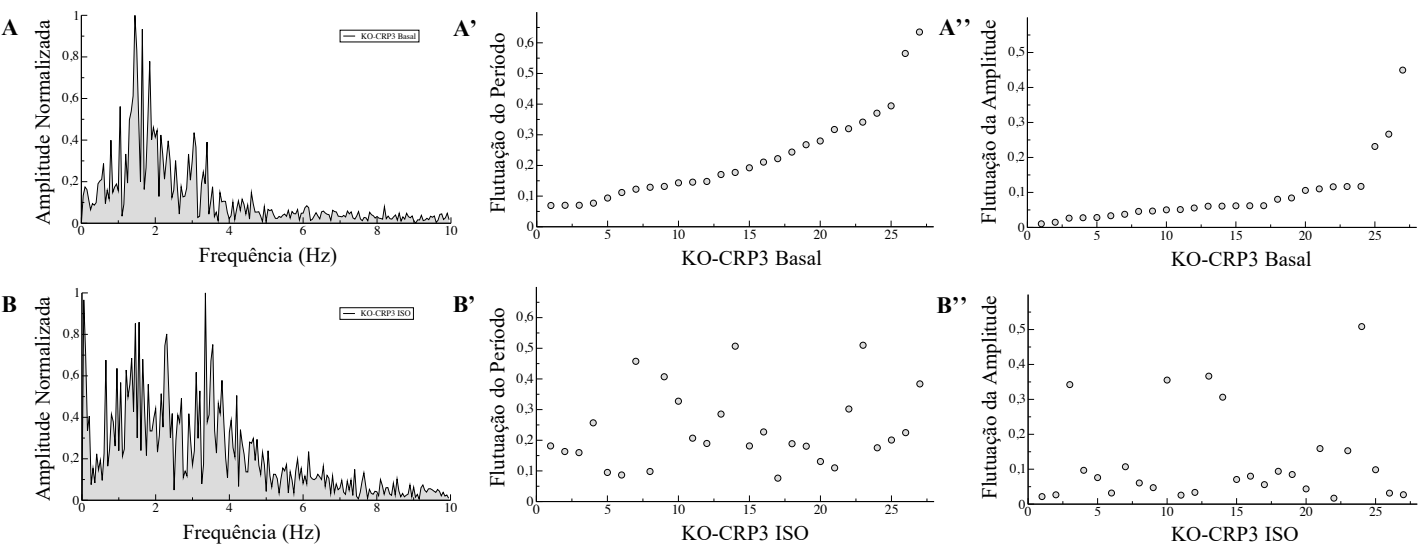

Figura 4.28: A: Comportamento da frequência média da $F_{\mathrm{T}}$ da linhagem KO-CRP3 no estado basal. A': Variação da flutuação do período em torno da média dos cardiomiócitos da linhagem KO-CRP3 no estado basal. A": Variação da flutuação da amplitude em torno da média dos cardiomiócitos da linhagem KO-CRP3 no estado basal. B: Comportamento da frequência média da $F_{\mathrm{T}}$ da linhagem KO-CRP3 estimulado com o isoproterenol. B': Variação da flutuação do período em torno da média dos cardiomiócitos da linhagem KO-CRP3 estimulados com isoproterenol. B" Variação da flutuação da amplitude em torno da média dos cardiomiócitos da linhagem KO-CRP3 estimulados com isoproterenol.

Analisando a Fig.4.28, é possível verificar que, diferente da linhagem WT, a flutuação do período e da amplitude aumenta para a maioria dos cardiomiócitos da linhagem KO-CRP3, quando estimulados com isoproterenol. Um dos fatores que pode estar gerando essa maior flutuação dos parâmetros é o aumento do ruído no comportamento da frequência média da linhagem que o isoproterenol ocasiona. $\mathrm{O}$ isoproterenol não induz nessa linhagem o mesmo efeito na linhagem WT. Os cardiomiócitos da linhagem KO-CRP3 não apresentam uma frequência bem definida, e com o isoproterenol essa variação aumenta mais ainda, fazendo com que a flutuação do período e da amplitude no sinal da $F_{\mathrm{T}}$ seja maior.

Nota-se que o isoproterenol foi fundamental para verificar diferença entre as linhagens. No estado basal a maioria dos cardiomiócitos se comportam de formas semelhantes, em ambas as linhagens. No entanto, quando estimuladas com o isoproterenol a resposta dos cardiomiócitos é diferente entre as linhagens, para a maioria dos parâmetros analisados neste trabalho.

Por fim, a metodologia desenvolvida para análise da flutuação do período e da amplitude no comportamento $F_{\mathrm{T}}$ durante o ciclo de contração, de uma forma geral, além de poder ser utilizada para comparação entre uma situação de controle (estado 
basal) e com algum estímulo ou variação, também pode ser utilizada como critério de exclusão de células das análises. Por exemplo, quando um cardiomiócito apresentar uma variação muito maior do que a média do conjunto analisado pode-se verificar com mais atenção o comportamento da $F_{\mathrm{T}}$ e caso seja necessário, excluí-lo da análise . Para exemplificar, a Fig.4.29 mostra o comportamento da $F_{\mathrm{T}}$ durante o ciclo de contração do mesmo cardiomiócito, da linhagem WT no estado basal e estimulado com isoproterenol, onde, no estado basal o tamanho da caixa é maior que com isoproterenol, indicando uma maior flutuação na amplitude.
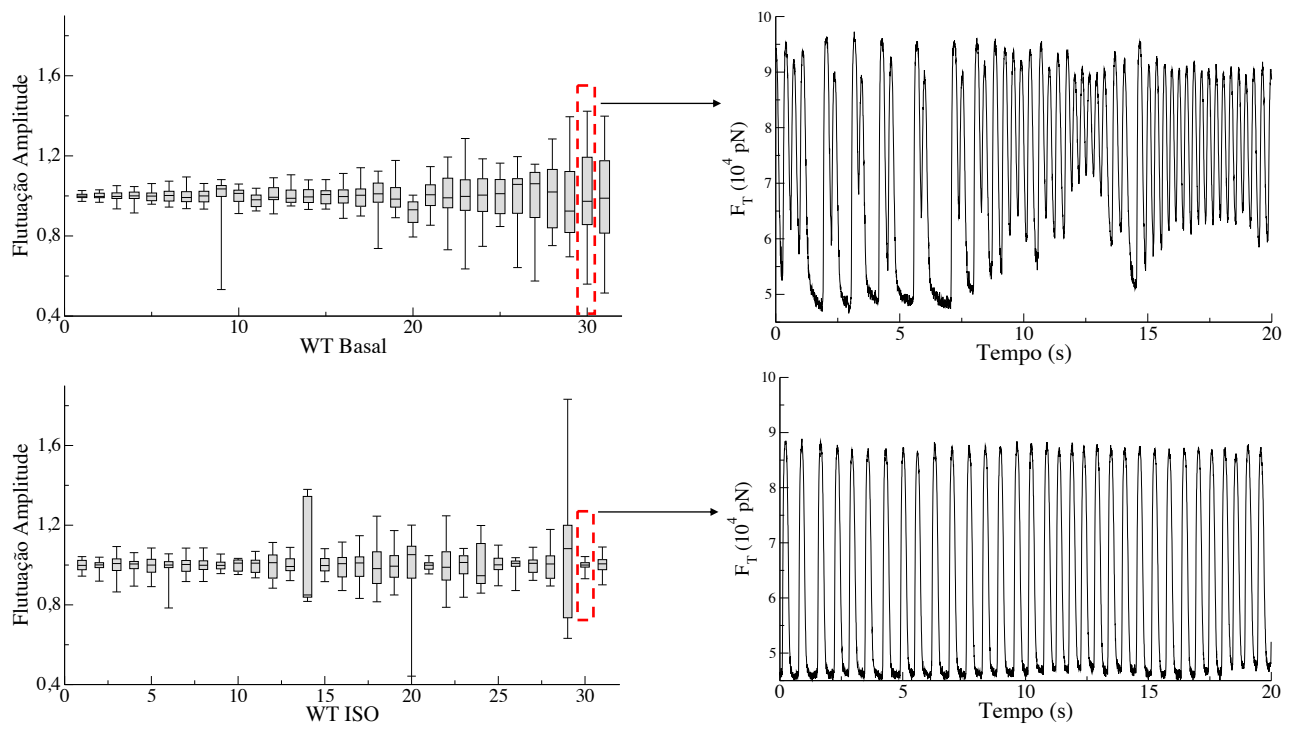

Figura 4.29: O gráfico ilustra o comportamento da $F_{\mathrm{T}}$ durante o ciclo de contração para um cardiomiócito da linhagem WT no estado basal e com isoproterenol. No estado basal o tamanho da caixa é significativamente maior que com isoproterenol. O gráfico da $F_{\mathrm{T}}$ ao longo do tempo mostra que essa variação na flutuação é visível entre os estados.

A flutuação do período também pode ser um bom indicativo para observar com mais cuidado uma determinada célula, antes de prosseguir com as análises, como pode ser visto na Fig.4.30, Nessa figura, apresenta-se o comportamento da $F_{\mathrm{T}}$ ao longo do tempo para uma amostra de cardiomiócito da linhagem KO-CRP3 no estado basal e com isoproterenol, onde a flutuação no período é significativamente maior no estado com isoproterenol e isso pode ser verificado no comportamento da $F_{\mathrm{T}}$. 

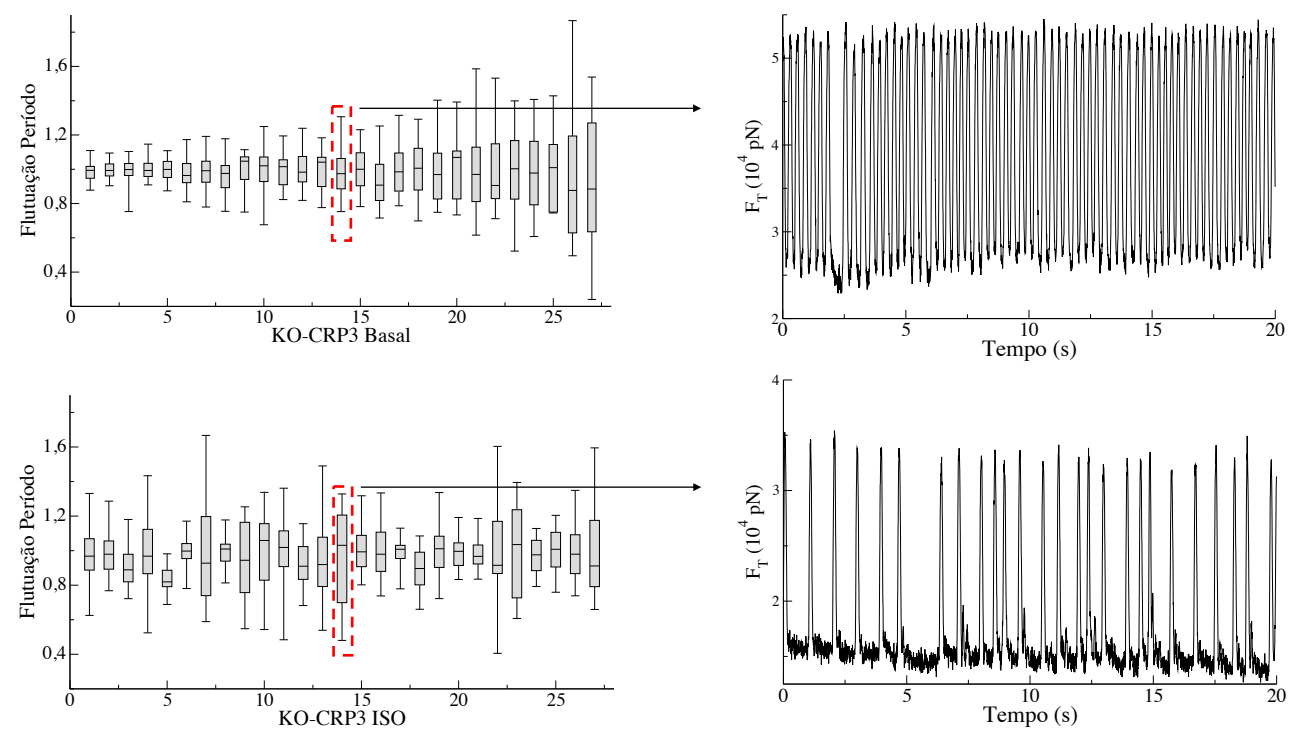

Figura 4.30: $\mathrm{O}$ gráfico ilustra o comportamento da $F_{\mathrm{T}}$ durante o ciclo de contração para um cardiomiócito da linhagem KO-CRP3 no estado basal e com isoproterenol. Quando estimulado com isoproterenol, o tamanho da caixa é significativamente maior que no estado basal. O gráfico da $F_{\mathrm{T}}$ ao longo do tempo mostra que essa variação na flutuação pode ser verificada entre os estados. 


\subsection{Conclusões}

No decorrer desse estudo foi possível desenvolver ferramentas computacionais capazes de analisar parâmetros importantes para colaborar no entendimento da dinâmica de forças de tração durante o ciclo de contração de cardiomiócitos, objetivo maior desse trabalho. Durante esse período de doutoramento, foi possível adquirir experiência na área experimental, com o aprendizado da técnica do TFM, bem como, no cultivo de células, e na área teórica com o desenvolvimento do código computacional para processar os dados obtidos pela técnica de TFM, bem como as análises realizadas sobre a dinâmica de forças nas linhagens de cardiomiócitos.

Com os resultados apresentados, foi possível atingir os objetivos propostos na pesquisa. Os experimentos de TFM foram realizados com sucesso e foi possível obter uma quantidade de amostras suficiente para as análises. A ferramenta computacional desenvolvida mostrou-se eficaz em realizar as análises propostas, gerando diversos resultados relacionados à dinâmica de força de tração dos cardiomiócitos. As análises nas linhagens de cardiomiócitos utilizadas, e com o uso do isoproterenol, são inovadoras e é possível contribuir para um melhor entendimento acerca da dinâmica de forças de tração durante o ciclo de contração dos cardiomiócitos.

Os resultados apresentados sugerem que o bloqueio da proteína CPR3 faz com que os cardiomiócitos dessa linhagem não consigam responder da mesma forma que cardiomiócitos normais, da linhagem WT, quando são mais exigidos energeticamente, como foi observado com o uso do isoproterenol. São diversos os fatores que podem estar relacionados a isso e, nesse trabalho, alguns parâmetros que são afetados por esse comportamento puderam ser estudos e melhor compreendidos. As interpretações ainda estão em aberto e é necessário um trabalho em parceria com os pesquisadores do Incor, que colaboraram com o fornecimento dos cardiomiócitos, para contribuir na construção de um modelo mais amplo que relaciona os parâmetros mecânicos com os biológicos, além dos aspectos morfológicos referentes às estruturas internas dos cardiomiócitos.

A metodologia de análise aqui desenvolvida, pode ser facilmente utilizada em outros contextos e novos trabalhos estão sendo planejados nesse sentido com outros tipos celulares como, por exemplo, células de mioblastos C2C12. Outro exemplo, seria realizar os experimentos em cardiomiócitos adultos e verificar se a linhagem KO-CRP3 é mais 
afetada pelo bloqueio da proteína CPR3, em relação à linhagem WT. Dessa forma, as análises aqui desenvolvidas se mostram versáteis e de fácil aplicação em diversos contextos de estudos em mecânica celular.

As medidas de TFM realizadas também foram diferenciadas, tendo em vista que a realização de filmagens a uma alta taxa de aquisição do campo de forças de tração dos cardiomiócitos, tendo em vista que geralmente o campo de força de tração é obtido apenas por duas imagens, uma do substrato com as células aderidas, e uma apenas do substrato, com os beads fluorescentes em sua posição inicial. Logo, diversos tipo de análises diferentes das desenvolvidas aqui, poderão ser realizadas. Isso mostra que, esse campo de pesquisa ainda está aberto e diversas contribuições científicas podem ser realizadas.

Por fim, pretendemos facilitar o uso do código computacional desenvolvido, deixando-o acessível para diversos pesquisadores utilizá-lo. Atualmente, estamos realizando pesquisas paralelas para complementar o estudo realizado e com isso, ter dados relevantes para futuras publicações científicas. 


\section{Referências Bibliográficas}

Alberts B., Johnson A., Lewis J., Morgan D., Raff M., Roberts K., Walter P., Wilson J., Hunt T., Biologia molecular da célula. Artmed Editora, 2010

Alcaraz J., Buscemi L., Grabulosa M., Trepat X., Fabry B., Farré R., Navajas D., Microrheology of human lung epithelial cells measured by atomic force microscopy, Biophysical journal, 2003, vol. 84, p. 2071

Alford P. W., Nesmith A. P., Seywerd J. N., Grosberg A., Parker K. K., Vascular smooth muscle contractility depends on cell shape, Integrative Biology, 2011, vol. 3, p. 1063

Arber S., Halder G., Caroni P., Muscle LIM protein, a novel essential regulator of myogenesis, promotes myogenic differentiation, Cell, 1994, vol. 79, p. 221

Arber S., Hunter J. J., Ross Jr J., Hongo M., Sansig G., Borg J., Perriard J.-C., Chien K. R., Caroni P., MLP-deficient mice exhibit a disruption of cardiac cytoarchitectural organization, dilated cardiomyopathy, and heart failure, Cell, 1997, vol. 88, p. 393

Balaban N. Q., Schwarz U. S., Riveline D., Goichberg P., Tzur G., Sabanay I., Mahalu D., Safran S., Bershadsky A., Addadi L., et al., Force and focal adhesion assembly: a close relationship studied using elastic micropatterned substrates, Nature cell biology, 2001, vol. 3 , p. 466

Barnes H. A., Hutton J. F., Walters K., An introduction to rheology. Elsevier, 1989

Blanchoin L., Boujemaa-Paterski R., Sykes C., Plastino J., Actin dynamics, architecture, and mechanics in cell motility, Physiological reviews, 2014, vol. 94, p. 235 
Boal D., Mechanics of the Cell Cambridge University Press, New York, Cambridge, UK, 2002

Boothe S. D., Myers J. D., Pok S., Sun J., Xi Y., Nieto R. M., Cheng J., Jacot J. G., The effect of substrate stiffness on cardiomyocyte action potentials, Cell biochemistry and biophysics, 2016, vol. 74, p. 527

Breuer K. S., Microscale diagnostic techniques. Springer, 2005

Brown M. A., Wallace C. S., Anamelechi C. C., Clermont E., Reichert W. M., Truskey G. A., The use of mild trypsinization conditions in the detachment of endothelial cells to promote subsequent endothelialization on synthetic surfaces, Biomaterials, 2007, vol. 28 , p. 3928

Buehler M. J., Yung Y. C., Deformation and failure of protein materials in physiologically extreme conditions and disease, Nature materials, 2009, vol. 8, p. 175

Butler J. P., Tolić-Nørrelykke I. M., Fabry B., Fredberg J. J., Traction fields, moments, and strain energy that cells exert on their surroundings., American journal of physiology. Cell physiology, 2002, vol. 282, p. C595

Buyandelger B., Ng K.-E., Miocic S., Piotrowska I., Gunkel S., Ku C.-H., Knöll R., MLP (muscle LIM protein) as a stress sensor in the heart, Pflügers Archiv-European Journal of Physiology, 2011, vol. 462, p. 135

Campos L. C. G., Miyakawa A. A., Barauna V. G., Cardoso L., Borin T. F., Dallan L. A. d. O., Krieger J. E., Induction of CRP3/MLP expression during vein arterialization is dependent on stretch rather than shear stress, Cardiovascular research, 2009, vol. 83, p. 140

Canadas P., Laurent V. M., Oddou C., Isabey D., Wendling S., A cellular tensegrity model to analyse the structural viscoelasticity of the cytoskeleton, Journal of Theoretical Biology, 2002, vol. 218, p. 155

Carvalho H., Recco-pimentel S., , 2007 A Célula. $2^{a}$ edição

Chen C. S., Ingber D. E., Tensegrity and mechanoregulation: from skeleton to cytoskeleton, Osteoarthritis and Cartilage, 1999, vol. 7, p. 81 
Chong J. J., Yang X., Don C. W., Minami E., Liu Y.-W., Weyers J. J., Mahoney W. M., Van Biber B., Cook S. M., Palpant N. J., et al., Human embryonic-stem-cell-derived cardiomyocytes regenerate non-human primate hearts, Nature, 2014, vol. 510, p. 273

Cicuta P., Donald A. M., Microrheology: a review of the method and applications, Soft Matter, 2007, vol. 3, p. 1449

Coughlin M. F., Bielenberg D. R., Lenormand G., Marinkovic M., Waghorne C. G., Zetter B. R., Fredberg J. J., Cytoskeletal stiffness, friction, and fluidity of cancer cell lines with different metastatic potential, Clinical \& experimental metastasis, 2013, vol. 30, p. 237

Dawid I. B., Breen J. J., Toyama R., LIM domains: multiple roles as adapters and functional modifiers in protein interactions, Trends in Genetics, 1998, vol. 14, p. 156

Dembo M., Wang Y.-L., Stresses at the cell-to-substrate interface during locomotion of fibroblasts, Biophysical journal, 1999, vol. 76, p. 2307

Deng L., Fairbank N. J., Fabry B., Smith P. G., Maksym G. N., Localized mechanical stress induces time-dependent actin cytoskeletal remodeling and stiffening in cultured airway smooth muscle cells, American Journal of Physiology-Cell Physiology, 2004, vol. 287, p. C440

Dinardo C. L., Venturini G., Omae S. V., Zhou E. H., da Motta-Leal-Filho J. M., Dariolli R., Krieger J. E., Alencar A. M., Costa Pereira A., Vascular smooth muscle cells exhibit a progressive loss of rigidity with serial culture passaging, Biorheology, 2012, vol. 49, p. 365

Dinardo C. L., Venturini G., Zhou E. H., Watanabe I. S., Campos L. C. G., Dariolli R., da Motta-Leal-Filho J. M., Carvalho V. M., Cardozo K. H. M., Krieger J. E., et al., Variation of mechanical properties and quantitative proteomics of VSMC along the arterial tree, American Journal of Physiology-Heart and Circulatory Physiology, 2013, vol. 306, p. H505

Discher D. E., Janmey P., Wang Y.-1., Tissue cells feel and respond to the stiffness of their substrate, Science, 2005, vol. 310, p. 1139 
Donoho D. L., et al., Compressed sensing, IEEE Transactions on information theory, 2006, vol. 52, p. 1289

Dorta M. P., de Brito I. V., Pereira A. C., Alencar A. M., Quantification of alignment of vascular smooth muscle cells, Cytometry Part A, 2018, vol. 93, p. 533

Engler A. J., Carag-Krieger C., Johnson C. P., Raab M., Tang H.-Y., Speicher D. W., Sanger J. W., Sanger J. M., Discher D. E., Embryonic cardiomyocytes beat best on a matrix with heart-like elasticity: scar-like rigidity inhibits beating, Journal of cell science, 2008, vol. 121, p. 3794

Fabry B., Maksym G. N., Butler J. P., Glogauer M., Navajas D., Fredberg J. J., Scaling the microrheology of living cells, Physical review letters, 2001, vol. 87, p. 148102

Frigge M., Hoaglin D. C., Iglewicz B., Some implementations of the boxplot, The American Statistician, 1989 , vol. 43 , p. 50

Gaui E. N., Oliveira G. M. M. d., Klein C. H., Mortality by heart failure and ischemic heart disease in Brazil from 1996 to 2011, Arquivos brasileiros de cardiologia, 2014, vol. 102 , p. 557

Gavara N., Roca-Cusachs P., Sunyer R., Farré R., Navajas D., Mapping cell-matrix stresses during stretch reveals inelastic reorganization of the cytoskeleton, Biophysical journal, 2008, vol. 95 , p. 464

Gerthoffer W. T., Mechanisms of vascular smooth muscle cell migration, Circulation research, 2007, vol. 100, p. 607

Hannezo E., Prost J., Joanny J.-F., Mechanical instabilities of biological tubes, Physical review letters, 2012, vol. 109, p. 018101

Harris A. K., Wild P., Stopak D., et al., Silicone rubber substrata: a new wrinkle in the study of cell locomotion, Science, 1980, vol. 208, p. 177

Harris F. J., On the use of windows for harmonic analysis with the discrete Fourier transform, Proceedings of the IEEE, 1978, vol. 66, p. 51

Heisenberg C.-P., Bellaïche Y., Forces in tissue morphogenesis and patterning, Cell, 2013, vol. 153, p. 948 
Hochmuth F., Shao J.-Y., Dai J., Sheetz M. P., Deformation and flow of membrane into tethers extracted from neuronal growth cones, Biophysical journal, 1996, vol. 70, p. 358

Humphries J. D., Wang P., Streuli C., Geiger B., Humphries M. J., Ballestrem C., Vinculin controls focal adhesion formation by direct interactions with talin and actin, The Journal of cell biology, 2007, vol. 179, p. 1043

Ingber D. E., Cellular tensegrity: defining new rules of biological design that govern the cytoskeleton, Journal of cell science, 1993, vol. 104, p. 613

Ingber D. E., Tensegrity I. Cell structure and hierarchical systems biology, Journal of cell science, 2003a, vol. 116, p. 1157

Ingber D. E., Tensegrity II. How structural networks influence cellular information processing networks, Journal of cell science, 2003b, vol. 116, p. 1397

Ingber D. E., Cellular mechanotransduction: putting all the pieces together again, The FASEB journal, 2006, vol. 20, p. 811

Jansen K. A., Donato D. M., Balcioglu H. E., Schmidt T., Danen E. H., Koenderink G. H., A guide to mechanobiology: where biology and physics meet, Biochimica et Biophysica Acta (BBA)-Molecular Cell Research, 2015, vol. 1853, p. 3043

Jensen L., Neri E., Bassaneze V., De Almeida Oliveira N. C., Dariolli R., Turaça L. T., Levy D., Veronez D., Ferraz M. S., Alencar A. M., et al., Integrated molecular, biochemical, and physiological assessment unravels key extraction method mediated influences on rat neonatal cardiomyocytes, Journal of cellular physiology, 2018, vol. 233, p. 5420

Kamm R. D., Cellular fluid mechanics, Annual review of fluid mechanics, 2002, vol. 34, p. 211

Kampstra P., et al., Beanplot: A boxplot alternative for visual comparison of distributions, 2008

Kardas D., Nackenhorst U., Balzani D., Computational model for the cell-mechanical response of the osteocyte cytoskeleton based on self-stabilizing tensegrity structures, Biomechanics and modeling in mechanobiology, 2013, vol. 12, p. 167 
Karlon W. J., Hsu P.-P., Li S., Chien S., McCulloch A. D., Omens J. H., Measurement of orientation and distribution of cellular alignment and cytoskeletal organization, Annals of biomedical engineering, 1999, vol. 27, p. 712

Kasza K., Broedersz C., Koenderink G., Lin Y., Messner W., Millman E., Nakamura F., Stossel T., MacKintosh F., Weitz D., Actin filament length tunes elasticity of flexibly cross-linked actin networks, Biophysical journal, 2010, vol. 99, p. 1091

Katira P., Zaman M. H., Bonnecaze R. T., How changes in cell mechanical properties induce cancerous behavior, Physical review letters, 2012, vol. 108, p. 028103

Katoh K., Misawa K., Kuma K.-i., Miyata T., MAFFT: a novel method for rapid multiple sequence alignment based on fast Fourier transform, Nucleic acids research, 2002, vol. 30 , p. 3059

Kemeny S. F., Clyne A. M., A simplified implementation of edge detection in MATLAB is faster and more sensitive than fast fourier transform for actin fiber alignment quantification, Microscopy and Microanalysis, 2011, vol. 17, p. 156

Khokhlova A., Balakina-Vikulova N., Katsnelson L., Iribe G., Solovyova O., Transmural cellular heterogeneity in myocardial electromechanics, The Journal of Physiological Sciences, 2018, vol. 68, p. 387

Kijlstra J. D., Hu D., Mittal N., Kausel E., van der Meer P., Garakani A., Domian I. J., Integrated analysis of contractile kinetics, force generation, and electrical activity in single human stem cell-derived cardiomyocytes, Stem Cell Reports, 2015, vol. 5, p. 1226

Kim K., Taylor R., Sim J., Park S.-J., Norman J., Fajardo G., Bernstein D., Pruitt B., Calibrated micropost arrays for biomechanical characterisation of cardiomyocytes, Micro \& Nano Letters, 2011, vol. 6, p. 317

Kollmannsberger P., Fabry B., Linear and nonlinear rheology of living cells, Annual review of materials research, 2011, vol. 41, p. 75

Lakowicz J. R., , 1999 in , Principles of fluorescence spectroscopy. Springer pp 367-394 
Landau L. D., Lifshitz E., Theory of Elasticity, vol. 7, Course of Theoretical Physics, 1986, vol. 3, p. 109

Lichtman J. W., Conchello J.-A., Fluorescence microscopy, Nature methods, 2005, vol. 2, p. 910

Lim C., Zhou E., Quek S., Mechanical models for living cells-a review, Journal of biomechanics, 2006, vol. 39, p. 195

Louch W. E., Sheehan K. A., Wolska B. M., Methods in cardiomyocyte isolation, culture, and gene transfer, Journal of molecular and cellular cardiology, 2011, vol. 51, p. 288

Lubarsky B., Krasnow M. A., Tube morphogenesis: making and shaping biological tubes, Cell, 2003, vol. 112, p. 19

Ludwig T., Kirmse R., Poole K., Schwarz U. S., Probing cellular microenvironments and tissue remodeling by atomic force microscopy, Pflügers Archiv-European Journal of Physiology, 2008, vol. 456, p. 29

McNeil P. L., Murphy R. F., Lanni F., Taylor D. L., A method for incorporating macromolecules into adherent cells., The Journal of cell biology, 1984, vol. 98, p. 1556

Madonna R., Ferdinandy P., De Caterina R., Willerson J. T., Marian A. J., Recent developments in cardiovascular stem cells, Circulation research, 2014, vol. 115, p. e71

Mandadapu K. K., Govindjee S., Mofrad M. R., On the cytoskeleton and soft glassy rheology, Journal of biomechanics, 2008, vol. 41, p. 1467

Matsumoto T., Nagayama K., Tensile properties of vascular smooth muscle cells: bridging vascular and cellular biomechanics, Journal of biomechanics, 2012, vol. 45, p. 745

Mertz A. F., Banerjee S., Che Y., German G. K., Xu Y., Hyland C., Marchetti M. C., Horsley V., Dufresne E. R., et al., Scaling of traction forces with the size of cohesive cell colonies, Physical Review Letters, 2012, vol. 108, p. 198101

Moeendarbary E., Harris A. R., Cell mechanics: principles, practices, and prospects, Wiley Interdisciplinary Reviews: Systems Biology and Medicine, 2014, vol. 6, p. 371 
Mofrad M. R., Rheology of the cytoskeleton, Annual Review of Fluid Mechanics, 2009, vol. 41 , p. 433

Moriya H., Colen D., Maksym G., Alencar A., CITOMETRIA ÓPTICO-MAGNÉTICA DE ROTAÇÃO: EXEMPLO DE UM MÉTODO PARA MEDIR AS PROPRIEDADES REOLÓGICAS DA CÉLULA. In 21o Congresso Brasileiro de Engenharia Biomédica , 2008, p. 1234

Müller D. J., Dufrene Y. F., , 2010 in , Nanoscience And Technology: A Collection of Reviews from Nature Journals. World Scientific pp 269-277

Parikh S. S., Zou S. Z., Tung L., Contraction and relaxation of isolated cardiac myocytes of the frog under varying mechanical loads., Circulation research, 1993, vol. 72, p. 297

Pelham Jr R. J., Wang Y.-L., Cell locomotion and focal adhesions are regulated by the mechanical properties of the substrate, The Biological Bulletin, 1998, vol. 194, p. 348

Penttinen K., Siirtola H., Avalos-Salguero J., Vainio T., Juhola M., Aalto-Setala K., Novel Analysis Software for Detecting and Classifying Ca2+ Transient Abnormalities in Stem Cell-Derived Cardiomyocytes, PLOS ONE, 2015, vol. 10, p. 1

Pfeiffer E. R., Tangney J. R., Omens J. H., McCulloch A. D., Biomechanics of cardiac electromechanical coupling and mechanoelectric feedback, Journal of biomechanical engineering, 2014, vol. 136, p. 021007

Plotnikov S. V., Sabass B., Schwarz U. S., Waterman C. M., , 2014 in , Vol. 123, Methods in cell biology. Elsevier pp 367-394

Pollard T. D., Cooper J. A., Actin, a central player in cell shape and movement, Science, 2009, vol. 326, p. 1208

Prinzen F. W., Peschar M., Relation between the pacing induced sequence of activation and left ventricular pump function in animals, Pacing and Clinical Electrophysiology, 2002, vol. 25, p. 484

Puig-de Morales M., Millet E., Fabry B., Navajas D., Wang N., Butler J. P., Fredberg J. J., Cytoskeletal mechanics in adherent human airway smooth muscle cells: probe 
specificity and scaling of protein-protein dynamics, American Journal of PhysiologyCell Physiology, 2004, vol. 287, p. C643

Qiu H., Zhu Y., Sun Z., Trzeciakowski J. P., Gansner M., Depre C., Resuello R. R., Natividad F. F., Hunter W. C., Genin G. M., et al., Vascular smooth muscle cell stiffness as a mechanism for increased aortic stiffness with agingnovelty and significance, Circulation research, 2010, vol. 107, p. 615

Quinn T. A., Bayliss R. A., Kohl P., , 2011 in , Heart rate and rhythm. Springer pp 133-151

Raucher D., Sheetz M. P., Characteristics of a membrane reservoir buffering membrane tension, Biophysical journal, 1999, vol. 77, p. 1992

Ribeiro A. J., Ang Y.-S., Fu J.-D., Rivas R. N., Mohamed T. M., Higgs G. C., Srivastava D., Pruitt B. L., Contractility of single cardiomyocytes differentiated from pluripotent stem cells depends on physiological shape and substrate stiffness, Proceedings of the National Academy of Sciences, 2015, vol. 112, p. 12705

Safran S., Gov N., Nicolas A., Schwarz U., Tlusty T., Physics of cell elasticity, shape and adhesion, Physica A: Statistical Mechanics and its Applications, 2005, vol. 352, p. 171

Sala L., Van Meer B. J., Tertoolen L. G., Bakkers J., Bellin M., Davis R. P., Denning C., Dieben M. A., Eschenhagen T., Giacomelli E., et al., MUSCLEMOTION: a versatile open software tool to quantify cardiomyocyte and cardiac muscle contraction in vitro and in vivo, Circulation research, 2018, vol. 122, p. e5

Sanderson M. J., Smith I., Parker I., Bootman M. D., Fluorescence microscopy, Cold Spring Harbor Protocols, 2014, vol. 2014, p. pdb

Schwarz U. S., Soiné J. R., Traction force microscopy on soft elastic substrates: A guide to recent computational advances, Biochimica et Biophysica Acta (BBA)-Molecular Cell Research, 2015, vol. 1853, p. 3095

Severs N. J., The cardiac muscle cell, Bioessays, 2000, vol. 22, p. 188

Shraiman B. I., Mechanical feedback as a possible regulator of tissue growth, Proceedings of the National Academy of Sciences, 2005, vol. 102, p. 3318 
Silveira P. S., Alencar A. M., Majumdar A., Lemos M., Fredberg J. J., Suki B., Percolation in a network with long-range connections: Implications for cytoskeletal structure and function, Physica A: Statistical Mechanics and its Applications, 2009, vol. 388, p. 1521

Squires T. M., Mason T. G., Fluid mechanics of microrheology, Annual review of fluid mechanics, 2010, vol. 42

Style R. W., Boltyanskiy R., German G. K., Hyland C., MacMinn C. W., Mertz A. F., Wilen L. A., Xu Y., Dufresne E. R., Traction force microscopy in physics and biology., Soft matter, 2014, vol. 10, p. 4047

Takahashi K., Kakimoto Y., Toda K., Naruse K., Mechanobiology in cardiac physiology and diseases, Journal of cellular and molecular medicine, 2013, vol. 17, p. 225

Tang X., Tofangchi A., Anand S. V., Saif T. A., A Novel Cell Traction Force Microscopy to Study Multi-Cellular System, PLoS Computational Biology, 2014, vol. 10

Tian J., Tu C., Huang B., Liang Y., Zhou J., Ye X., Study of the union method of microelectrode array and AFM for the recording of electromechanical activities in living cardiomyocytes, European Biophysics Journal, 2017, vol. 46, p. 495

Tipler P. A., Mosca G., Física para cientistas e engenheiros. Vol. 1: mecânica, oscilações e ondas, termodinâmica .. Grupo Gen-LTC, 2000

Tirziu D., Giordano F. J., Simons M., Cell communications in the heart, Circulation, 2010, vol. 122 , p. 928

Trepat X., Lenormand G., Fredberg J. J., Universality in cell mechanics, Soft Matter, 2008, vol. 4, p. 1750

Turro N. J., Modern molecular photochemistry. University science books, 1991

Valeur B., Berberan-Santos M. N., Molecular fluorescence: principles and applications. John Wiley \& Sons, 2012

Vaziri A., Xue Z., Kamm R., Mofrad M. K., A computational study on power-law rheology of soft glassy materials with application to cell mechanics, Computer methods in applied mechanics and engineering, 2007, vol. 196, p. 2965 
Vikhorev P., Vikhoreva N., Cardiomyopathies and Related Changes in Contractility of Human Heart Muscle, International journal of molecular sciences, 2018, vol. 19, p. 2234

Wang J., Li B., The principles and biological applications of cell traction force microscopy, Microscopy: Science, Technology, Applications and Education. Formatex, Badajoz, Spain, 2010, pp 449-458

Yamaoka H., Matsushita S., Shimada Y., Adachi T., Multiscale modeling and mechanics of filamentous actin cytoskeleton, Biomechanics and modeling in mechanobiology, 2012, vol. 11, p. 291

Ye G. J., Aratyn-Schaus Y., Nesmith A. P., Pasqualini F. S., Alford P. W., Parker K. K., The contractile strength of vascular smooth muscle myocytes is shape dependent, Integrative Biology, 2014, vol. 6, p. 152

Yeung T., Georges P. C., Flanagan L. A., Marg B., Ortiz M., Funaki M., Zahir N., Ming W., Weaver V., Janmey P. A., Effects of substrate stiffness on cell morphology, cytoskeletal structure, and adhesion, Cell motility and the cytoskeleton, 2005, vol. 60, p. 24

Yoshigi M., Clark E. B., Yost H. J., Quantification of stretch-induced cytoskeletal remodeling in vascular endothelial cells by image processing, Cytometry Part A, 2003, vol. 55, p. 109

Zhang Y., Sekar R. B., McCulloch A. D., Tung L., Cell cultures as models of cardiac mechanoelectric feedback, Progress in biophysics and molecular biology, 2008, vol. 97, p. 367

Zhu C., Bao G., Wang N., Cell mechanics: mechanical response, cell adhesion, and molecular deformation, Annual review of biomedical engineering, 2000, vol. 2, p. 189

Zhuo X.-Z., Wu Y., Ni Y.-J., Liu J.-H., Gong M., Wang X.-H., Wei F., Wang T.-Z., Yuan Z., Ma A.-Q., et al., Isoproterenol instigates cardiomyocyte apoptosis and heart failure via AMPK inactivation-mediated endoplasmic reticulum stress, Apoptosis, 2013, vol. 18, p. 800 
Zielinski R., Mihai C., Kniss D., Ghadiali S. N., Finite element analysis of traction force microscopy: influence of cell mechanics, adhesion, and morphology, Journal of biomechanical engineering, 2013, vol. 135, p. 071009

Zimmermann W.-H., Melnychenko I., Wasmeier G., Didié M., Naito H., Nixdorff U., Hess A., Budinsky L., Brune K., Michaelis B., et al., Engineered heart tissue grafts improve systolic and diastolic function in infarcted rat hearts, Nature medicine, 2006, vol. 12 , p. 452

Zou Y., Komuro I., Yamazaki T., Kudoh S., Uozumi H., Kadowaki T., Yazaki Y., Both Gs and Gi proteins are critically involved in isoproterenol-induced cardiomyocyte hypertrophy, Journal of Biological Chemistry, 1999, vol. 274, p. 9760 
Apêndice 



\section{Apêndice A}

\section{Protocolo da preparação do substrato de gel do TFM}

A preparação do gel do TFM envolve, basicamente, três etapas. O processo todo de preparação é delicado e com vários detalhes, devido a isso, optou-se por descrever aqui essas etapas.

\section{A.1 Primeira etapa: Preparação da primeira camada do gel}

Essa etapa, envolve, principalmente, a ativação química do pocinho, que é uma placa com fundo de vidro de $35 \mathrm{~mm}$, onde o gel será depositado. Inicialmente, se faz o tratamento dos poços com silano e a solução de glutaraldeído, ambos tóxicos. Nesse processo será gerado descarte de material tóxico, que poderá ser recolhido em um recipiente vazio com tampa, para ser descartado apropriadamente. O tratamento segue as seguintes etapas:

1. Pipetar $\approx 60 \mu \mathrm{L}$ de silano puro ou $\approx 1000 \mu \mathrm{L}$ de silano diluído diretamente sobre as lamínulas dos pocinhos e aguardar, respectivamente, 6 ou 30 minutos.

2. Lavar os pocinhos 3 ou 4 vezes com água destilada para remover o silano.

3. Preparar uma solução de $0,5 \%$ de glutaraldeído em PBS e depois adicionar $200 \mu \mathrm{L}$ dessa solução em cada pocinho e aguardar 30 minutos. A quantidade de solução deve ser o suficiente para preencher completamente a lamínula de vidro no fundo do pocinho.

4. Lavar os pocinhos 3 ou 4 vezes com água destilada para remover a solução. 
5. Deixar os pocinhos secarem por aproximadamente 40 minutos, ou mais, caso ainda não esteja completamente seco.

Com a lamínula de vidro no fundo do pocinho quimicamente ativada para receber o substrato, inicia-se o processo de preparo da primeira camada do gel com a rigidez de 9,6 kPa, que é mais adequada para adesão dos cardiomiócitos. Esse processo segue as seguintes etapas:

1. Diluir 1,0\% de APS (Ammonium Persufate) em pó, em água deionizada. Exemplo: $200 \mu \mathrm{L}$ de água deionizada em 2 mg de APS em pó.

2. Em um ependorf, adicionar $188 \mu \mathrm{L}$ de acrilamida, $59 \mu \mathrm{L}$ de bisacrilamida e $620 \mu \mathrm{L}$ de água deionizada.

3. Em seguida, adicionar no mesmo ependorf, 1,0 $\mu \mathrm{L}$ de TMED e $100 \mu \mathrm{L}$ da solução de APS já realizada. Essa solução serve para catalisar a reação de polimerização entre a acrilamida e o bisacilamida do gel.

4. Com a solução no ependorf pronta, misturar bem no vortex e adicionar $3,2 \mu \mathrm{L}$ da solução em cada pocinho. Em seguida, cobrir o gel com lamínulas de vidro circular, com $9 \mathrm{~mm}$ de diâmetro, e aguardar o fim do processo de polimerização (em torno de 30 minutos). Nessa etapa, o gel deve ser recoberto pelas lamínulas antes de polimerizar, ou seja, todo o processo deve ser realizado rapidamente. Por isso, recomenda-se já deixar as lamínulas separadas para recobrir o gel antes.

5. Adicionar água deionizada até cobrir toda a superfície da lamínula para que ela seja retirada do gel. Use pinça ou espátula para descolar, delicadamente, cada lamínula do gel.

6. Assim que as lamínulas forem retiradas, deve-se adicionar água deionizada ao pocinho para não deixar o gel secar.

\section{A.2 Segunda etapa: Preparação da segunda camada do gel}

1. Nessa etapa, a diferença é que se reduz a quantidade de água deionizada para se acrescentar o volume com a solução de beads fluorescentes (já preparada). Em geral, 
adiciona-se de $30 \mu \mathrm{L}$ a $60 \mu \mathrm{L}$ da solução de beads na solução. O volume de beads adicionados, deve ser retirado do volume de água deionizada. Exemplo: Em um eppendorf, adicionar $188 \mu \mathrm{L}$ de acrilamida, $59 \mu \mathrm{L}$ de bisacrilamida, $60 \mu \mathrm{L}$ de beads e $560 \mu \mathrm{L}$ de água deionizada.

2. Em seguida, adicionar no mesmo eppendorf, 1,0 $\mu \mathrm{L}$ de TMED e $100 \mu \mathrm{L}$ da solução de APS já realizada.

3. Com a solução no eppendorf pronta, misturar bem no vortex e, adicionar $1,0 \mu \mathrm{L}$ da solução em cima da primeira camada de gel, já pronta no pocinho. Em seguida, cobrir o gel com lamínulas de vidro circular, com $9 \mathrm{~mm}$ de diâmetro, e aguardar o fim do processo de polimerização.

4. Adicionar água deionizada até cobrir toda a superfície da lamínula para que ela seja retirada do gel. Use pinça ou espátula para descolar, delicadamente, cada lamínula do gel.

5. Assim que as lamínulas forem retiradas, deve-se adicionar água deionizada ao pocinho para não deixar o gel secar.

6. Após o término dessa etapa, deve-se colocar os pocinhos preparados em uma placa de Petri, fechá-la e recobri-la com papel alumínio.

7. Guardar na geladeira. Tempo de armazenamento na geladeira é em torno de 20 dias.

\section{A.3 Terceira etapa: Ativação do gel para depósito dos cardiomiócitos}

1. Fazer o preparo no fluxo laminar. Deixar o fluxo limpo, uma placa de Petri grande e um tubo falcon de $15 \mathrm{~m} \ell$.

2. Adicionar ao falcon, o volume de um eppendorf de sulfo-sanpah com $5 \mathrm{~m} \ell$ de PBS. Fazer essa operação com pouca luz e rápido.

3. Retirar os pocinhos com o substrato de gel da geladeira e sugar toda a água.

4. Adicionar $300 \mu \mathrm{L}$ da solução de slufo-sanpah sobre o gel. 
5. Deixar os pocinhos no fluxo laminar durante 20 minutos para serem esterilizados por uma luz ultra-violeta.

6. Preparar a solução de colágeno bovino (comercial) em PBS utilizando uma proporção de $40 \mu \mathrm{L} / \mathrm{m} \ell$. Colocar $300 \mu \mathrm{L}$ dessa solução em cada pocinho. Por exemplo, vamos supor que pretende-se preparar uma solução para 6 pocinhos, como em cada pocinho precisamos de $300 \mu \mathrm{L}$ da solução, no total precisaremos de $1800 \mu \mathrm{L}$ que, para garantir, aproximamos para $2000 \mu \mathrm{L}$ de solução. Como a concentração deve ser de $40 \mu \mathrm{L}$ de colágeno bovino em $1 \mathrm{~m} \ell$ de PBS, para um volume total de $2000 \mu \mathrm{L}$ de solução, a concentração deve ser de $80 \mu \mathrm{L}$ de colágeno. O colágeno bovino que foi utilizado é comercial e possui concentração de 5000 $\mathrm{mg} / \mathrm{m} \ell$. Como precisamos de uma concentração final de $80 \mu \mathrm{L}$, é necessário utilizar $16 \mu \mathrm{L}$ da solução de colágeno comercial. Por fim, sendo de $16 \mu \mathrm{L}$ o volume utilizado de colágeno, precisa-se de $1984 \mu \mathrm{L}$ de PBS, para que no final tenha-se uma solução de $2000 \mu \mathrm{L}$, necessária para os 6 pocinhos.

7. Após os 20 minutos, sugar toda a solução de sulfo-sanpah e lavar 3 vezes com PBS, deixando o gel sempre coberto com um pouco de PBS.

8. Adicionar $300 \mu \mathrm{L}$ da solução de colágeno em cima do gel de cada pocinho. Colocar os pocinhos em uma placa de Petri grande e transferir para a incubadora, onde, deverão permanecer por cerca de 1 hora e meia. Com esse processo feito, o gel está apto para receber os cardiomiócitos. Esse preparo do gel com a solução de colágeno faz com que, as células consigam aderir no gel e fazer adesões focais. 


\section{Apêndice $\mathrm{B}$}

\section{Trabalho publicado sobre a metodologia de alinhamento}

A metodologia desenvolvida para o alinhamento das forças de tração, descritas na seção 3.2. teve como base um trabalho desenvolvida pelo presente autor, para quantificação do alinhamento de fibras de actina de imagens de microscopia confocal de células vasculares de músculo liso. Esse trabalho iniciou-se durante a minha pesquisa de mestrado. No entanto, a versão final dessa metodologia de análise foi completamente refeita e finalizada durante o meu doutoramento. Por isso, achamos interessante adicionar aqui o resultado desse trabalho, que pode ser visto abaixo. 


\title{
Cytometry \\ $\angle$ ISAC Journal of $\mathrm{Q}$
}

\section{Quantification of Alignment of Vascular Smooth Muscle Cells}

\author{
Marcel P. Dorta, ${ }^{1}$ Isis V. de Brito, ${ }^{1}$ Alexandre C. Pereira, ${ }^{2}$ Adriano M. Alencar ${ }^{1 \star}$
}

'Laboratory of Microrheology and Molecular Physiology, Department of General Physics, Physics Institute, University of São Paulo, São Paulo, Brazil

2Laboratory of Genetics and Molecular Cardiology, Department of Cardiology, Heart Institute, Medical School, University of São Paulo, São Paulo, Brazil

Received 25 September 2017; Revised 5 February 2018; Accepted 13 February 2018

Grant sponsor: Fundação de Amparo à Pesquisa do Estado de São Paulo (FAPESP), Grant number: 2012/07059-8, 2014/21646-9, and 2014/22102-2

Additional Supporting Information may be found in the online version of this article.

${ }^{*}$ Correspondence to: Adriano M. Alencar Instituto de Física, Rua do Matão 1371, travessa R. 05508-090, São Paulo/SP, Brazil. Email: aalencar@usp.br

Published online 26 March 2018 in Wiley Online Library (wileyonlinelibrary.com)

DOI: 10.1002/cyto.a.23355

(C) 2018 International Society for Advancement of Cytometry

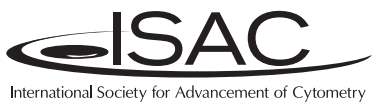

\section{- Abstract}

Vascular smooth muscle cells (VSMCs) are essential components that keep the tonus of the arterial network, which is the channel used to conduct the blood from the heart to the peripheral areas of the body. It is known that mechanical and architectural changes in VSMCs may lead to functional modifications in the cardiovascular system; therefore, the quantitative characterization of these changes can help to elucidate questions that remain unclear in pathological situations, such as hypertension, vasospasm, vascular hypertrophy, and atherosclerosis. In this work, we have developed a new framework of image processing using the Sobel operator, associated with statistical analysis, to determine the degree of local alignment of actin filaments, which we found to be directly related with the distensibility of the arterial wall. We have also compared these results with the rigidity of the cytoskeleton of VSMCs. The results suggest that the alignment degree increases from peripheral arteries, such as carotid and femoral, to central arteries, as well coronary and thoracic aorta, which can indicate that the level of local alignment of the actin fibers in VSMCs is related with the mechanical behavior of the arterial wall. ๑ 2018 International Society for Advancement of Cytometry

- Key terms

F-actin; Kurtosis; arterial tonus; rheology; viscoelasticity

THE smooth muscle cells (SMCs) control the tonus of hollow organs of the mammalians body. Specifically, for vessels and arteries, the vascular SMCs (VSMCs) contributes to the mechanical properties of the vascular system (1), which is critical for their main functions, such as, contraction, blood pressure regulation, and blood flow distribution (2). The VSMCs also present a singular plasticity, and can exhibit phenotypic changes in response to environmental or physiological stimulus $(3,4)$. In applied research, it has been shown that the VSMC mechanical properties present a significant intraindividual and interindividual variation $(5,6)$, anomalous and quake-like dynamics (7). These behaviors are mainly determined by the cytoskeleton, mostly through actin filaments, which also defines the cell architecture (8-10). Therefore, the only way to fully understand the relationship between the structure of VSMCs and mechanical behavior of the arterial system goes through the characterization of the cytoskeleton (F-actin) organization (11). Thus, we have developed a set of tools to analyze images of VSMCs to perform this characterization, associating the results with the distensibility of the arterial wall and with the stiffness of the cytoskeleton of these cells.

Advanced fluorescence and optical methods associated with image processing techniques have been used to analyze structural changes associated with the reorganization of the F-actin (12). In general, the raw digital images from biological samples must be preprocessed to suppress imperfections, artifacts from the acquisition process and undesired noise background, or to enhance some important features for further processing (13). Following this step, depending on the scientific question, the processing itself varies hugely, leading to the use of a significant amount of different 
analytical techniques, such as methods based on fast Fourier transform (FFT) and the edge identification by Sobel operator. Specifically, these can be used as cell image processing techniques to quantify the alignment of the intracellular fibers (14-16). These two methods were compared in the work of Kemeny and Clyne (17), in which they have shown that edge detection methods, such the Sobel operator, are more sensitive than FFT methods.

In the works of Yoshigi et al. (14), image processing algorithms were used to calculate the degree of cytoskeleton fiber alignment of vascular endothelial cells, expressing the results of variance and Kurtosis of F-actin distribution angle. Based on this work, we have developed a novel VSMC image analysis platform composed of specific functions, organized in an algorithm that aims to quantify the degree of alignment (DA) of F-actin in VSMC's. Our image-processing platform uses the Sobel operator to identify the borders of the F-actin and calculate the angle per pixel. The alignment of F-actin in several small regions of the image is estimated by determining the Kurtosis of the angle distribution for each region $(14,17)$. To demonstrate the application possibilities of our method we have calculated the DA of fibers of VSMCs, using images of cells obtained from different porcine arterial beds (5). We have hypothesized that the structural properties, such as the alignment of the F-actin, can determine the organization of the whole VSMC, and can also be related to the elastic behavior of the arterial wall. Thus, based on this hypothesis, we have compared our results with mechanical parameters of these two arterial elements: the viscoelasticity of the cytoskeleton of VSMCs (5) and the pressure-strain elastic modulus $\left(E_{\mathrm{P}}\right)$, obtained from the literature $(18,19)$. This is a parameter that relates pressure and diameter changes during the systole and diastole cycle (19). Through our analysis, we have shown that, the parameters that characterize the F-actin organization of VSMCs can be related to the mechanical behavior of the arterial wall, but they did not show a good correspondence with the stiffness of the cytoskeleton of these cells.

\section{Methodological Developments}

Detailed descriptions of the cell culture and isolation are reported elsewhere (5). Briefly, fragments of abdominal aorta, femoral, renal, carotid, coronary, and thoracic aorta arteries were collected from five pigs to isolate VSMCs using the primary explant technique. The cells were either fixed and incubated with phalloidin conjugated with Alexa (1:400; Alexa Fluor 488 Phalloidin; Invitrogen) or for $12 \mathrm{~h}$ with antivinculin primary antibody (1:200; catalog no. V9131; SigmaAldrich). In the latter case, followed by $2 \mathrm{~h}$ incubation with anti-mouse secondary antibody (Alexa Fluor 555 goat antimouse IgG, 1:500; Invitrogen). Confocal images were acquired using a Zeiss laser-scanning confocal microscope LSM 510 META using the 20x objective lens (Plan-Apo/0.75 NA) $(5,20)$. The emission filter bandwidth is $505-550 \mathrm{~nm}$ with the center at $518 \mathrm{~nm}$. The procedure was approved according to our local ethics committee (CAPpesq-Hospital das Clínicas da Faculdade de Medicina USP-0272/11).

\section{Preprocessing and Analysis}

The confocal system generates a LSM file format, which is an extended multi page TIFF-format that can hold few standard TIFF data channels, usually one image per dye. Here, we only need the channel tailored to visualize F-actin. Our analysis platform was built in Matlab ${ }^{\circledR}$ and was based on three main steps: in the first, we preprocess uncompressed TIFF ( 8 bits, $512 \times 512$ pixels) confocal images of vascular smooth muscle cells (VSMCs) $(14,17)$, then we apply an algorithm of edge detection and calculate the DA using the methodology that will be summarized here. For each arterial bed, we used a set of six images.

During the preprocessing, the data of the F-actin labeled fluorescence images were adjusted, improving the contrast of the actin fibers: we used a generalization of the Otsu method to eliminate the image background noise, which is widely used for this purpose (17,21-25). That method establishes an optimum threshold $L_{c}$, however, often, due the experimental setup, the noise and the signal are too close and the threshold $L_{\mathrm{c}}$ may not be the best choice. This is the case of our images where the pure Otsu method generated a very high $L_{c}$ (Fig. 1B). Thus, to overcome this difficulty, but keeping a user independent threshold selection, we applied a single correction factor for all images, $L_{\mathrm{cg}}=\alpha L_{\mathrm{c}}$, where here, $\alpha=0.3$, which eliminates most of the noise, keeping the information from the fibers (Fig. 1C).

\section{Quantification of the DA}

To quantify the DA, the Sobel operator was used, adopting the methodological procedures described by Yoshigui et al. (14). Given a gray scale image, this operator calculates the brightness of each pixel $P_{i, j}$, where $i$ and $j$ represent the coordinates of the pixel, of an image using the following horizontal and vertical convolution matrixes:

$$
\begin{gathered}
M_{h}=\left(\begin{array}{ccc}
-1 & 0 & 1 \\
-2 & 0 & 2 \\
-1 & 0 & 1
\end{array}\right), \\
M_{v}=\left(\begin{array}{ccc}
-1 & -2 & -1 \\
0 & 0 & 0 \\
1 & 2 & 1
\end{array}\right),
\end{gathered}
$$

where $M_{h}$ and $M_{v}$ represent, respectively, the magnitude of the brightness gradient in horizontal and vertical directions. The neighbors of each pixel were selected as a sample matrix $S_{i, j}$ :

$$
S_{i, j}=\left(\begin{array}{ccc}
P_{i-1, j-1} & P_{i-1, j} & P_{i-1, j+1} \\
P_{i, j-1} & P_{i, j} & P_{i, j+1} \\
P_{i+1, j-1} & P_{i+1, j} & P_{i+1, j+1}
\end{array}\right) .
$$

Thus, during image analysis, the horizontal $\left(H_{h}\right)$ and vertical $\left(H_{v}\right)$ convolutions were calculated using the following expressions: 

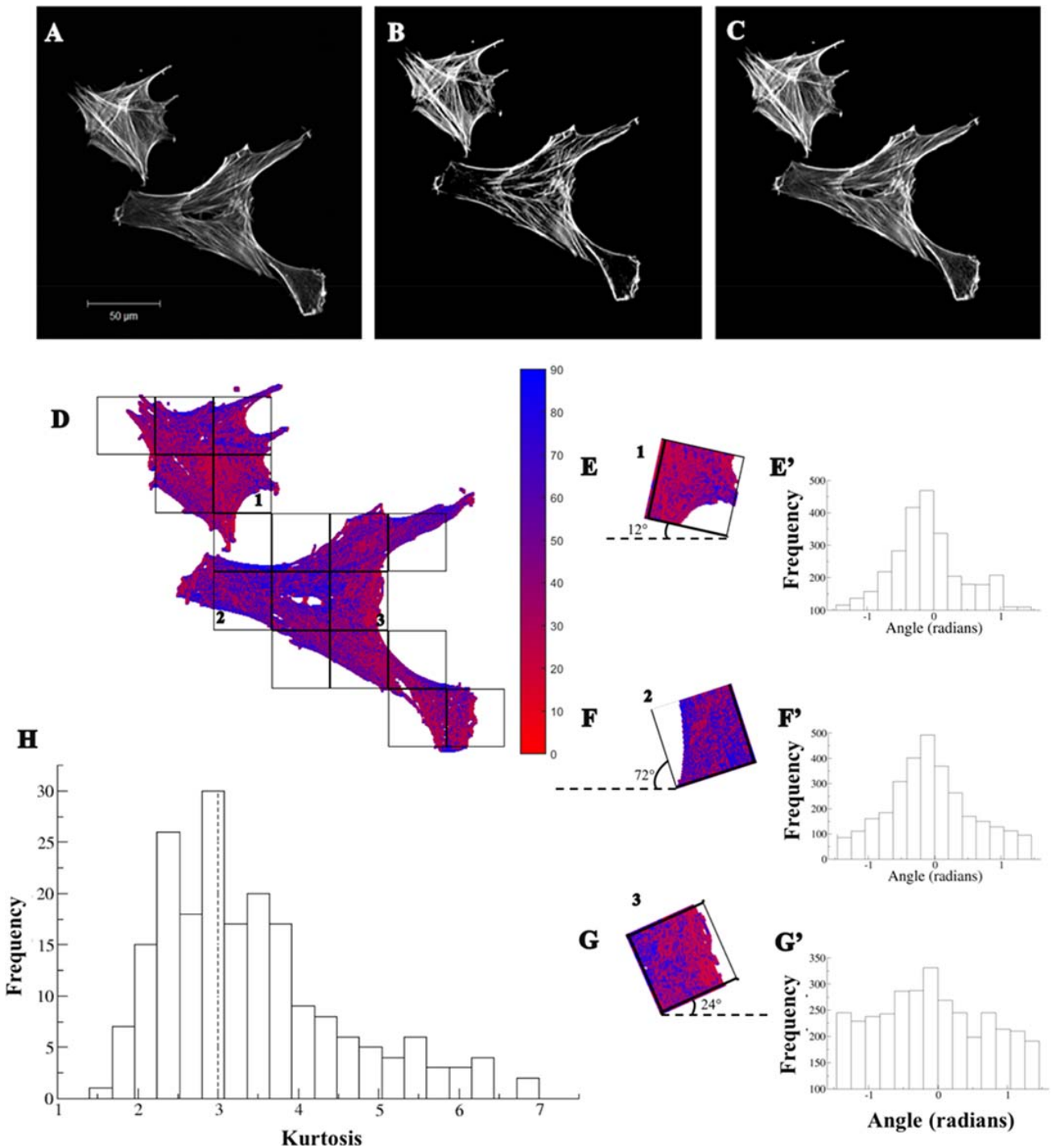

Figure 1. Quantification of the degree of alignment of actin fibers of VSMCs using statistical analysis. We applied a generalization of the Otsu method to improve the contrast of our fluorescence labeled images (A). In B, we have an image adjusted by an optimal threshold $\left(L_{\mathrm{c}}\right)$ determined by the Otsu's traditional method, which applied a very high $L_{\mathrm{c}}$. To overcome this problem, we applied the condition $L_{\mathrm{cg}}=\alpha L_{\mathrm{C}}$, where $\alpha=0.3$ (C). D: Grayscale (or online color) coded image representing the angles per pixel of thoracic aorta divided in $16 \times 16$ squared windows. The grayscale version's (color code) was implemented to differentiate the orientation angles for each pixel: for angles closer to $\pi / 2$ rad, the pixel fibers' shades were white (blue) and for angles closer to 0 rad, pixel fibers' shades were black (red). From F to $\mathbf{G}$ : Rotation of the preferential angle to zero in local regions numbered from 1 to 3 . From $\mathbf{F}^{\prime}$ to $\mathbf{G}^{\prime}$ : Histograms of the angles for each local region, after the rotation. $\mathbf{H}$ : Histogram of the Kurtosis for all the local regions in the image presented in D. A dotted line for $K=3$ indicates the region where the integral of the Eq. (8) is applied, after a normalization, to evaluate the degree of alignment of the cells. [Color figure can be viewed at wileyonlinelibrary.com]

$$
\begin{aligned}
& H_{h}(i, j)=\sum M_{h} \cdot S_{i, j}, \\
& H_{v}(i, j)=\sum M_{v} \cdot S_{i, j} .
\end{aligned}
$$

The values of $H_{h}(i, j)$ and $H_{v}(i, j)$ represent the magnitude of the brightness gradient along the horizontal and vertical directions, respectively. The angle $(\theta)$ for each pixel was calculated using the arctangent function:

$$
\theta(i, j)=\arctan \left(\frac{H_{v}}{H_{h}}\right) .
$$

Subsequently, a color-coding scheme was used to facilitate the characterization of the fibers directions. To simplify the interpretation, the orientation angles of the fibers have been adjusted between $-\pi / 2$ and $\pi / 2$ rad (Fig. 1D). By calculating the angle per pixel, using Eq. (6), and building its histogram, we could find the preferential angle. However, we note that, although the fibers of the cell are aligned in clusterized regions, those regions are not aligned to one another, tending to the global alignment vanishes. Thus, we divided the whole image in a set of $0>n>N$ small regions with $L \times L$ pixels, 
calculated the angle probability distributions of all regions, $\Pi_{n}(\theta)$, identifying the position of the peak of $\Pi_{n}(\theta)$, which we assigned to be the preferential orientation of $n$. We choose the size $L$ of these regions, so it could capture the alignment clusters. We rotated each subregion aiming that the preferential orientation becomes zero centered and the angles are redistributed to be between $-\pi / 2$ and $\pi / 2$ rad (see Figs. 1E$1 G)$. Then we called DA the dispersion of the distribution around zero by calculating the Kurtosis, $K\left[\Pi_{n}(\theta)\right]$, which is known to be a good descriptor of the shape of the distribution, which is given by:

$$
K\left[\Pi_{n}(\theta)\right]=\frac{1}{L 2} \frac{\left[\sum_{i, j}(\theta(i, j)-\bar{\theta})^{4}\right]}{\left(\sigma^{2}\right)^{2}},
$$

where $\bar{\theta}$ is the sample mean and $\sigma$ is the standard deviation of $\theta(i, j)$. Normal distributions have values of $K\left[\Pi_{n}(\theta)\right]=3$,while peaked distributions have $K\left[\Pi_{n}(\theta)\right]>3$, as can be seen in Figure 1E', and are considered highly aligned subregions. Distributions with $K\left[\Pi_{n}(\theta)\right]<3$ are flatter distributions with high dispersion, as can be seen in Figure 1G', and are considered regions with low DA. Thus, values of $K$ between 3 and $\infty$ characterize regions that are considered aligned. We obtained the probability distribution of the Kurtosis $\Pi(K)$ for the $N$ subregions, by normalizing its histogram (Figure $1 \mathrm{H}$ ) by the total area, as $\int_{0}^{\infty} \Pi(K) d K=1$. Finally, we defined the DA as:

$$
\mathrm{DA}=\int_{3}^{\infty} \Pi(K) d K
$$

We applied this methodology for different values of $L$, $8 \leq L \leq 32$ pixels, and they did not show significant variation, thus, we adopted $L=16$ as the window size because the average standard deviation of the DA was lower than the other sizes (Fig. 2B). Furthermore, this size showed to be more efficient to cover appropriately the images of the cells (Fig. 2E). Larger windows will include too much background (in Figs. 2C and 2D), while smaller windows will include only few fibers.

\section{Results AND Discussion}

Figures $3 \mathrm{~A}$ and $3 \mathrm{~B}$ show two images of VSMCs obtained from carotid and coronary arteries using fluorescence confocal microscope. From these images, which are from the same animal, one can notice a shape difference, but standard methods to measure the alignment are not able to detect differences.

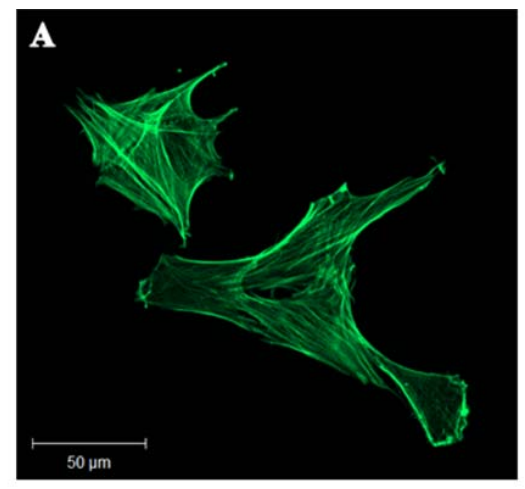

B

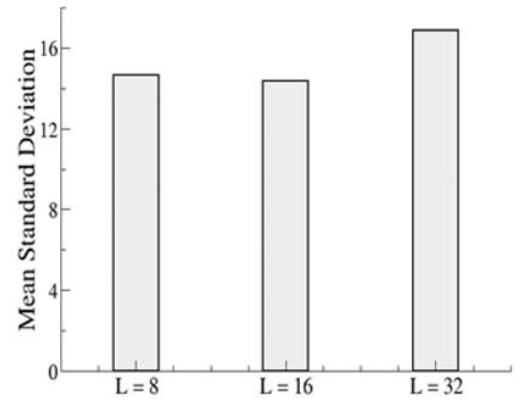

C

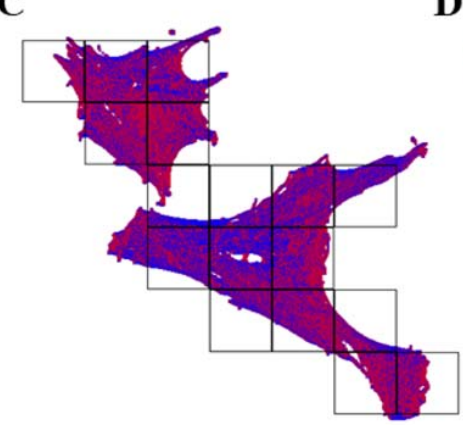

D

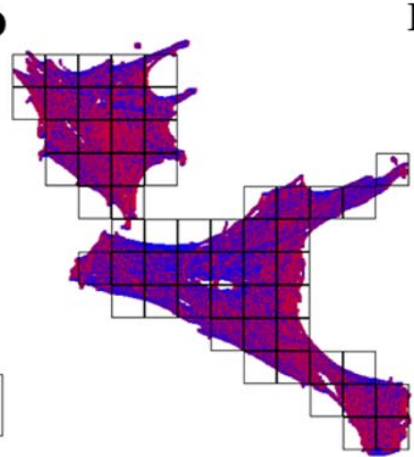

E

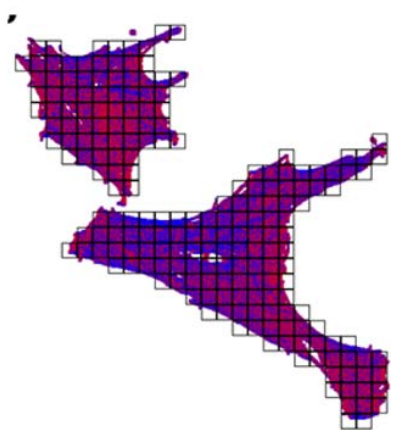

Figure 2. Cell imaging processing A: Fluorescence microscopy image of two VSMCs obtained from a porcine thoracic aorta using the methodology described previously. Samples were stained with phalloidin. Different windows sizes (C: 64 , D: 32 , and E: 16) were used to divide VSMCs images to calculate the degree of local alignment of the F-actin. Using six images, for each one of the six different arterial beds (femoral, carotid, thoracic aorta, abdominal aorta, coronary, and renal artery) used in this work, the degree of local alignment was estimated, and we decided to adopt $L=16$, because the results obtained using this window size showed a smaller mean standard deviation of the values of DA (B). As we can see from the picture, this window size is suitable for our purpose, because it covers almost the entire cell, reducing background regions and covering a number of fibers enough to generate reliable results. Note that, the size of $L$ has to change once the magnification used to take the images changes. [Color figure can be viewed at wileyonlinelibrary.com] 

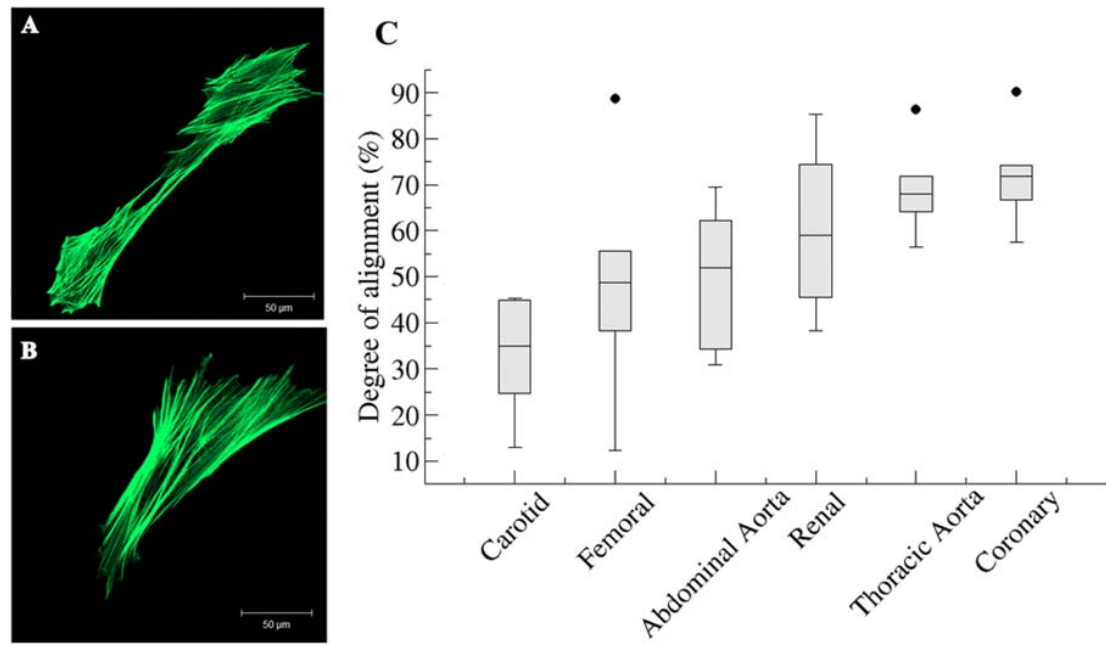

Figure 3. DA for VSMCs collected from different porcine arterial beds. The arteries are organized in a sequence: from peripheral to centra arteries. Fluorescence confocal images of A: thoracic aorta VSMCs and B: femoral VSMCs stained with phalloidin. The images indicate that the cells present different shape and alignment of the actin fibers. This difference may have influence on the mechanical behavior of the cells and, as a consequence, it may be related to the mechanical behavior of the arterial wall. C: Box plot of the DA (\%) for VSMCs from each arterial bed, where the dots are outliers. This result indicates that peripheral arteries presented more aligned cells than the central arteries, when we consider central arteries the ones that are closest to the heart and peripheral as the arteries near the extremities of the animal body (head and members). [Color figure can be viewed at wileyonlinelibrary.com]

However, using our previously described method, we can quantify the differences in the alignment of the internal fibers, as we can see in the box plot of the DA for six different arterial beds (Fig. 3C). It shows that peripheral vessels, such as carotid and femoral arteries(18), displayed lower DA values $(32.9 \%$ and $48.7 \%$, respectively) than the cells from central vessels, as thoracic and coronary artery $(69.1 \%$ and $72 \%$, respectively).

We have shown that the DA VSMC changes obtained from different regions of the arterial tree, increase from peripheral to central arteries, which may indicate that the structure of the VSMCs changes to be adapted to the arterial function. With the same idea in mind, several authors studied the mechanical properties of vessels $(5,18-20,26,27)$, such as Dinardo et al. (5), who showed that the VSMC rigidity, from the same set of images used here, increases as their vessel of origin moves away from the heart. These parameters were evaluated using optical magnetic twisting cytometry (OMTC) and our data of DA were plotted together for comparison. The Figure 4 shows the $Z$-score, or rigidity, from the apparent stiffness $(G)$ versus the DA of the VSMCs. Here, the arterial beds were distributed in the $\mathrm{x}$-axis, from the peripheral to central arteries. The rigidity shows a small fluctuation between the arterial beds, without a clear trend, while the DA increases. This difference can show that the rigidity of the cytoskeleton may not be influenced by the local alignment of the F-actin.

However, we observed that, among anatomical and structural parameters of vessels obtained from the literature $(5,18,19,28)$, such as media thickness, internal diameter, thickness/internal diameter, percentage of collagen and percentage of elastin, the arterial wall distensibility is the parameter that best correlates with DA. The distensibility is the inverse of the pressure-strain elastic modulus $\left(E_{\mathrm{P}}\right)$, as described by Slørdahl et al. (28). In this work, the authors evaluated the $E_{\mathrm{p}}$ of central arteries and show that the $E_{\mathrm{P}}$, from pig's central arteries, increase with the distance from the heart. From their results, we calculated the distensibility as the inverse of $E_{\mathrm{P}}$ for four different arterial beds in the aorta (ascending aorta, descending aorta, abdominal aorta high, and abdominal aorta low) and compared with our DA results, also from pigs (Fig. 3C), as is shown in Figure 5.

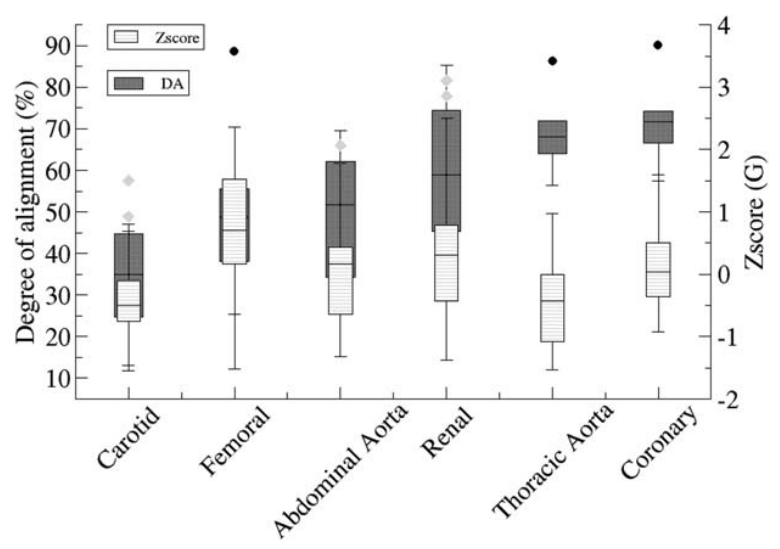

Figure 4. Box plot (light gray) representing the Z-scores of the variable $\mathrm{G}$ for each artery which indicates the VSMC rigidity according to the position in the arterial tree. This box plot was adapted from the original data obtained by Dinardo et al. (5). Here, we just changed the sequence of the arterial beds. The box plot of the DA (dark gray) is plotted with the Z-score for comparison. These graphs indicate that the alignment of the F-actin of VSMCs can be related with the mechanical behavior of the arterial wall, but it did not show a correlation with the rigidity of the VSMC cytoskeleton. 


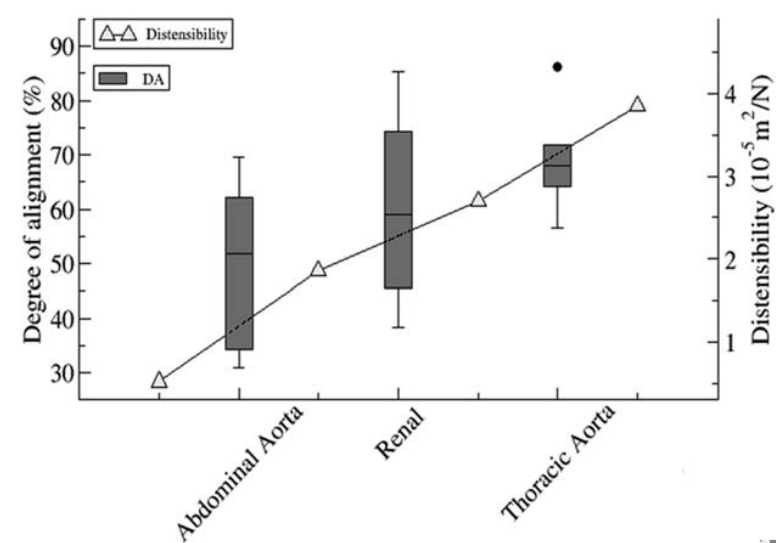

Figure 5. Comparison between our results and the data obtained by Slørdahl et al. (28) for four different arterial beds at the aorta of a set of six pigs (ascending aorta, descending aorta, abdominal aorta high, and abdominal aorta low). The arterial beds are distributed in the graph's axis as they are located in the animal's body. The box plot represents the data obtained in this work and the triangles represent the literature data.

Similar studies also shows that the arterial wall distensibility increases from peripheral to central arteries for dogs, Peterson et al. (19), and sheep, Mangell et al. (18). Thus, all of them agree that the three species follows the same tendency. In Figure 6, we extrapolate our results of VSMCs DA from pig (arterial beds: carotid, femoral, abdominal aorta and thoracic aorta) to compare against the distensibility of the arterial wall among different species, dog (19) and sheep (18). We can see that, for all the three species the distensibility and DA increases from peripheral to central arteries. Hence, from our data, we found that cells in arterial beds with more capacity of distension present more stress fibers aligned. We could, again, extrapolate our findings considering that the blood flow shear stress play an important role in arterial distensibility (29). Thus, the cell stress fibers alignment may be a consequence of the shear stress. If this is true, it can be used to couple macroscopic mechanical parameters with the microscopic cell structure.
Here, we have developed an innovative, user independent, and automated methodology for image analysis, which covers an important structural property of cells: the DA. We hypothesized that this parameter can be defined by the orientation of the actin fibers, which is a determinant element for the elastic behavior of the cardiovascular system. We applied our platform to perform a statistical analysis of images of vascular smooth muscle cells obtained from several segments collected from a porcine arterial tree. Our method showed to be efficient for determining the DA of VSMCs, since it enabled quantitative and fast analysis of the alignment of the fibers in local regions of the cells.

The methodology applied here was different from others, such as the one presented by Yoshigi et al. (14), and of Kemeny et al. (17), once we are not determining the preferential angle of the actin fibers, but the degree of local alignment. While our method is focusing on the individual cell properties, which may be directly related to the viscoelasticity and phenotype cell adaptation, the method suggested by Yoshigi et al. is focusing, for instance, on the collective and preferential alignment of a confluent group of cells forming a monolayer and under unidirectional mechanical stress. Thus, it is not possible to identify if the cytoskeleton of a given cell is more or less aligned than the cytoskeleton of another cell.

Our method can be used to any type of fiber inside a cell, as microtubules and intermediate filaments and can also be applied to human VSMCs or other human cells. However, the method needs to adopt a specific window size, which should be tested before processing the data, since the relative size of the cells varies from one experimental setup to another. The size of the window cannot reach the size of the cell, as well as, it cannot be too small. Thus, we found that the window size should be between $1 / 10$ and $1 / 40$ of the total cell length, in pixels. Another limitation was imposed by the image acquisition process, since focus adjustment of the image and fading of fluorochromes influenced the contrast of the fiber image. Despite these limitations, our method proved to be efficient to determine the degree of alignment of VSMCs and can be used to characterize the cell in different studies.
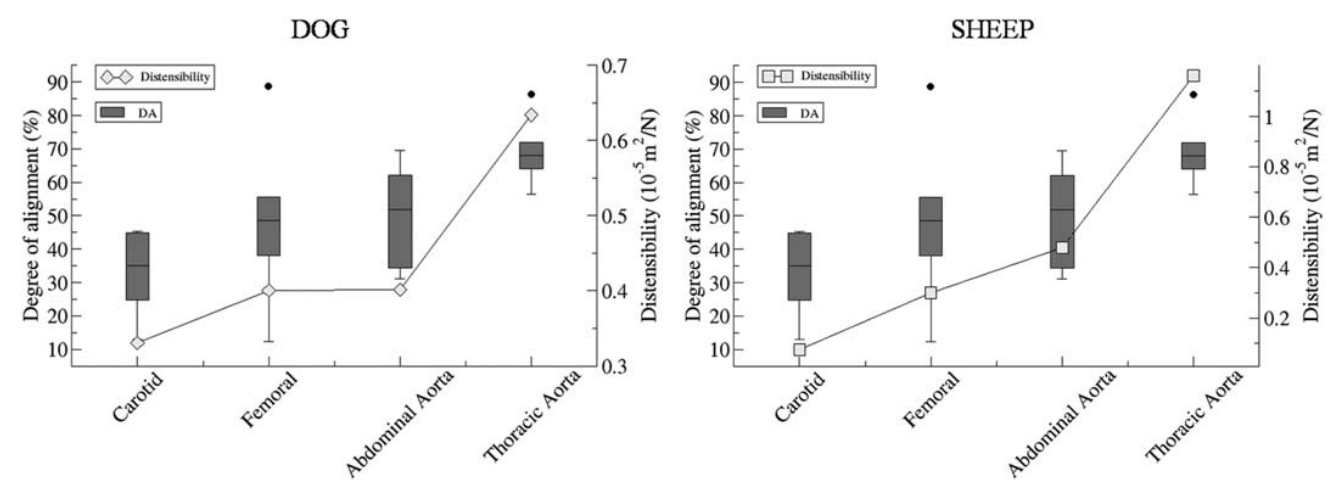

Figure 6. DA of VSMCs calculated from different porcine arterial beds compared with the inverse of pressure-strain elastic modulus (distensibility) of arteries for dog (diamonds) and sheep (squares) (19). It's been found modulus of thoracic aorta, abdominal aorta, femoral, and carotid arteries, but modules of renal and coronary arteries of the same animal were not found for comparison. 


\section{Literature Cited}

1. Wagenseil JE, Mecham RP. Vascular extracellular matrix and arterial mechanics. Physiol Rev 2009;89:957-989. Available at: http://physrev.physiology.org/cgi/doi/ $10.1152 /$ physrev.00041.2008

2. Owens GK, Kumar MS, Wamhoff BR. Molecular regulation of vascular smooth muscle cell differentiation in development and disease. Physiol Rev 2004;84:767-801. Available at: http://www.ncbi.nlm.nih.gov/pubmed/15269336 (accessed on January 23, 2014).

3. Rzucidlo EM, Martin KA, Powell RJ. Regulation of vascular smooth muscle cell differentiation. J Vasc Surg 2007;45(Suppl. A):A25-A32. Available at: http://www ncbi. nlm.nih.gov/pubmed/17544021 (accessed on February 17, 2014).

4. Seriani R, de Souza CEC, Krempel PG, Frias DP, Matsuda M, Correia AT, Ferreira MZJ, Alencar AM, Negri EM, Saldiva PHN, et al. Human bronchial epithelial cells exposed in vitro to diesel exhaust particles exhibit alterations in cell rheology and cytotoxicity associated with decrease in antioxidant defenses and imbalance in proand anti-apoptotic gene expression. Environ Sci Pollut Res 2016;23:9862-9870. Available at: http://link.springer.com/10.1007/s11356-016-6228-x.

5. Dinardo CL, Venturini G, Zhou EH, Watanabe IS, Campos LCG, Dariolli R, da Motta-Leal-Filho JM, Carvalho VM, Cardozo KHM, Krieger JE, et al. Variation of mechanical properties and quantitative proteomics of VSMC along the arterial tree. Am J Physiol Heart Circ Physiol 2014;306:H505-H516. Available at: http://www. $26,2014)$

6. Dinardo CL, Santos HC, Vaquero AR, Martelini AR, Dallan LAO, Alencar AM, Krieger JE, Pereira AC. Smoking and female sex: Independent predictors of human vascular smooth muscle cells stiffening Kirchmair R, editor. PLoS One 2015;10: e0145062. Available at: http://dx.plos.org/10.1371/journal.pone.0145062.

7. Alencar AM, Ferraz MSA, Park CY, Millet E, Trepat X, Fredberg JJ, Butler JP. Nonequilibrium cytoquake dynamics in cytoskeletal remodeling and stabilization. Soft
Matter 2016;12:8506-8511. Available at: http://xlink.rsc.org/?DOI=C6SM01041E.

8. Zhou EH, Martinez FD, Fredberg JJ. Cell rheology: Mush rather than machine. Nat Mater 2013;12:184-185. Available at:http://www.pubmedcentral.nih.gov/article render.fcgi artid $=3882307 \&$ tool $=$ pmcentrez\&rendertype $=$ abstract $\quad$ (accessed on January 29, 2014)

9. Fabry B, Maksym G, Butler J, Glogauer M, Navajas D, Fredberg J. Scaling the microrheology of living cells. Phys Rev Lett 2001;87:148102-148104. Available at: http:// rheology of living cells. Phys Rev Lett 2001;87:148102-148104. Available at: http://
link.aps.org/doi/10.1103/PhysRevLett.87.148102 (accessed on November 1, 2012).

10. Fletcher DA, Mullins RD. Cell mechanics and the cytoskeleton. Nature 2010;463: 485-492. Available at: http://www.nature.com/doifinder/10.1038/nature08908.

11. Alford PW, Nesmith AP, Seywerd JN, Grosberg A, Parker KK. Vascular smooth muscle contractility depends on cell shape. Integr Biol 2011;3:1063-1070. Available at: http://www.ncbi.nlm.nih.gov/pubmed/21993765 (accessed on February 24, 2014).

12. Li F, Yin Z, Jin G, Zhao H, Wong STC. Chapter 17: Bioimage Informatics for Systems Pharmacology Lewitter F, Kann M, editors. PLoS Comput Biol 2013;9:e1003043. Available at: http://www.pubmedcentral.nih.gov/articlerender.fcgi?artid=3635992\& tool $=$ pmcentrez\&rendertype $=$ abstract $($ accessed on August 19, 2013).

13. Russ JC. The Image Processing Handbook. Boca Raton, FL: CRC Press; 2010. 180 p.
14. Yoshigi M, Clark EB, Yost HJ. Quantification of stretch-induced cytoskeletal remodeling in vascular endothelial cells by image processing. Cytometry A 2003;55A:109-118.

15. Wong KYE, Chekima A, Dargham JA, Sainarayanan G. Palmprint identification using Sobel operator. In: 10th International Conference on Control, Automation,
Robotics and Vision, 2008. ICARCV 2008. Hanoi, Vietnam: IEEE; 2008. pp 13381341. Available at: http://ieeexplore.iee.org/document/4795716/.

16. Xu F, Beyazoglu T, Hefner E, Gurkan UA, Demirci U. Automated and adaptable quantification of cellular alignment from microscopic images for tissue engineering applications. Tissue Eng. C. Methods 2011;17:641-649. Available at: http://www pubmedcentral.nih.gov/articlerender. fcgi?artid $=3103056 \&$ tool $=$ pmcentrez\&rendertype $=$ abstract.

17. Kemeny SF, Clyne AM. A simplified implementation of edge detection in MATLAB is faster and more sensitive than fast fourier transform for actin fiber alignment quantification. Microsc Microanal 2011;17:156-166.

18. Mangell P, Länne T, Sonesson B, Hansen F, Bergqvist D. Regional differences in mechanical properties between major arteries-An experimental study in sheep. Eur J Vasc Endovasc Surg 1996;12:189-195. Available at: http://www.ncbi.nlm.nih.gov/ pubmed/8760981

19. Peterson LH, Jensen RE, Parnell J. Mechanical properties of arteries in vivo. Circ Res 1960;8:622-639.

20. Dinardo CL, Venturini G, Omae SV, Zhou EH, da Motta-Leal-Filho JM, Dariolli R, Krieger JE, Alencar AM, Costa Pereira A. Vascular smooth muscle cells exhibit a progressive loss of rigidity with serial culture passaging. Biorheology 2012;49:365-373.

21. Doan MXQ, Sarvari AK, Fischer-Posovszky P, Wabitsch M, Balajthy Z, Fesus L, Bacso Z. High content analysis of differentiation and cell death in human adipocytes. Cytometry A 2013;83:933-943.

22. Jin-Yu Z, Yan C, Xian-Xiang H. Edge detection of images based on improved Sobel operator and genetic algorithms. In: International Conference on Image Analysis and Signal Processing, IASP 2009. Linhai, China, China: IEEE; 2009. pp 31-35.

23. Shah SA, Santago P, Rubin BK. Quantification of biopolymer filament structure. Ultramicroscopy 2005;104:244-254

24. Parameswaran H, Majumdar A, Ito S, Alencar AM, Suki B. Quantitative characterization of airspace enlargement in emphysema. J Appl Physiol 2006;100:186-193.

25. Chinga G, Johnsen PO, Dougherty R, Berli EL, Walter J. Quantification of the 3D microstructure of SC surfaces. J Microsc 2007;227:254-265.

26. Isnard RN, Pannier BM, Laurent S, London GM, Diebold B, Safar ME. Pulsatile diameter and elastic modulus of the aortic arch in essential hypertension: A noninvasive study. J Am Coll Cardiol 1989;13:399-405.

27. Labropoulos N, Ashraf MM, Kang SS, Oh DS, Buckman J, Baker WH. Viscoelastic properties of normal and atherosclerotic carotid arteries. Eur J Vasc Endovasc.Surg 2000;19:221-225.

28. Slørdahl SA, Piene H, Linker DT, Vik A. Segmental aortic wall stiffness from intravascular ultrasound at normal and subnormal aortic pressure in pigs. Act Physiol Scand 1991;143:227-232. Available at: http://doi.wiley.com/10.1111/j.17481716.1991.tb09226.x

29. Baltgaile G. Arterial wall dynamics. Perspect Med 2012;1:146-151. Available at: http://linkinghub.elsevier.com/retrieve/pii/S2211968X12000563. 